\title{
Mammals of the \\ La Selva-Braulio Carrillo \\ Complex, Costa Rica
}

by

\author{
Robert M. Timm \\ Don E. Wilson \\ Barbara L. Clauson \\ Richard K. LaVal \\ Christopher S. Vaughan
}
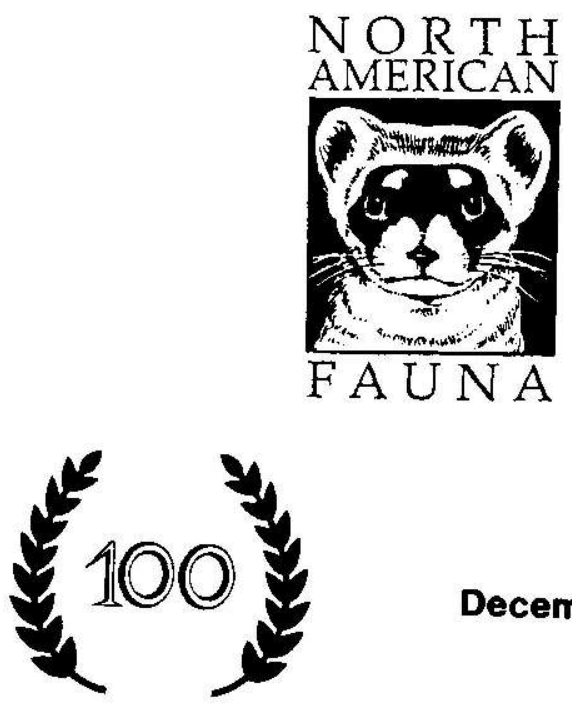

December 1989

UNITED STATES DEPARTMENT OF THE INTERIOR

FISH AND WILDLIFE SERVICE

North American Fauna 75 



\section{Contents}

Page

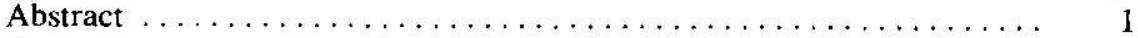

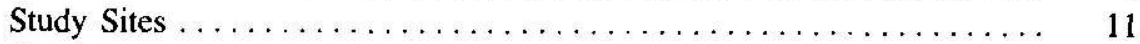

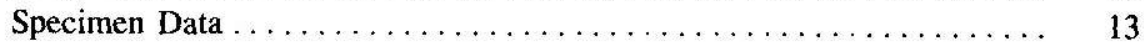

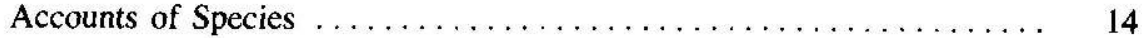

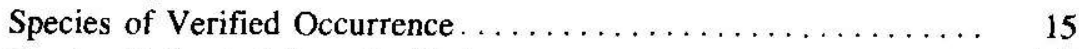

Species Extirpated from the Park . . . . . . . . . . . . . 148

Species of Possible or Probable Occurrence in the Area . . . . . . . 150

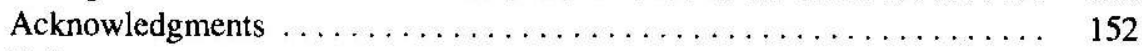

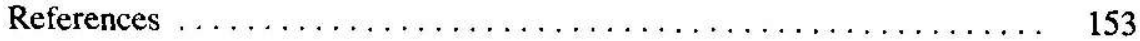





\title{
Mammals of the \\ La Selva-Braulio Carrillo \\ Complex, Costa Rica
}

\author{
by \\ Robert M. Timm \\ Museum of Natural History \\ Department of Systematics and Ecology \\ University of Kansas \\ Lawrence, Kansas 66045 \\ Don E. Wilson \\ U.S. Fish and Wildlife Service \\ National Ecology Research Center \\ Museum of Natural History \\ Washington, DC 20560 \\ Barbara L. Clauson \\ Museum of Natural History \\ University of Kansas \\ Lawrence, Kansas 66045 \\ Richard K. LaVal \\ Apartado 10165 \\ San José, Costa Rica \\ Christopher S. Vaughan \\ Programa Regional en Manejo de Vida Silvestre para \\ Mesoamérica y el Caribe \\ Universidad Nacional \\ Heredia, Costa Rica
}

\begin{abstract}
Costa Rica's La Selva-Braulio Carrillo complex encompasses a 60-km protected corridor of Caribbean rain and cloud forest extending from $30 \mathrm{~m}$ at the La Selva Biological Station to 2,906 m at the top of Volcán Barva. The 52,000-ha complex covers four life zones and two transitional zones, including tropical wet forest, tropical wet forest cool-transition, tropical premontane wet-transition rain forest, tropical premontane rain forest, lower montane rain forest, and montane rain forest. Located in the northeastern part of the country, the area is representative of Central American Caribbean slope forests that extend
\end{abstract}


from Mexico to Panama. The extensive elevational gradient of the complex provides protected habitat for a variety of altitudinal migrants.

With support from the National Geographic Society and Rice Foundation, the Organization for Tropical Studies organized a biological survey of the complex in early 1986. The mammal team worked at six sites along the elevational transect established by the expedition: $300 \mathrm{~m}, 700 \mathrm{~m}, 1,000 \mathrm{~m}, 1,500 \mathrm{~m}, 2,050 \mathrm{~m}$, and 2,600 m. We supplemented our collecting records with unpublished records made available by colleagues, records in the published literature, and specimens in museum collections. In addition, observations recorded by a variety of observers at the La Selva Biological Station are summarized.

The mammal fauna of the complex comprises 142 species including 79 bats, 23 rodents, 15 carnivores, 7 marsupials, 6 edentates, 4 artiodactyls, 3 primates, 2 rabbits, 2 shrews, and 1 perissodactyl. At least 10 additional species are likely to occur there. The only species of mammal likely to have been extirpated from the area is the giant anteater.

Recognizing the importance of the area to wildlife and to mankind in general, the government of Costa Rica added 13,500 ha to the complex on 13 April 1986. This area, previously known as the "Zona Protectora," provided the mid-elevational link between the lowlands of the La Selva Biological Station and the montane forests of Braulio Carrillo National Park. Unfortunately, destruction of the rain forests surrounding the complex will soon render it an isolated island of protected forest. Thus, the area will become increasingly valuable as a refuge for many species with home ranges that require extensive tracts of undisturbed habitat.

RESUMEN: El complejo La Selva-Braulio Carrillo de Costa Rica abarca un pasillo protejido de 60 kilómetros de bosque pluvial y selva nublada del Caribe. Extendiendose desde 30 metros sobre el nivel del mar, en la Estación Biológica de La Selva, hasta 2,906 metros, en la cima del Volcán Barva. El complejo de 52,000 hectáreas cubre cuatro zonas de vida y dos zonas de transición, incluyendo bosque húmedo tropical, bosque húmedo tropical con transición fría, bosque pluvial tropical pre-montano con transición húmeda, bosque pluvial pre-montano tropical, bosque pluvial montano-bajo, y bosque pluvial montano. Localizada en la parte noreste del país, el área es representativo de los bosques con pendiente de America Central y el Caribe que se extienden desde México hasta Panamá. La extensa gradiente de este complejo brinda lugares protejidos para una variedad de migrantes altitudinales.

Con el apoyo del National Geographic Society y Rice Foundation, la Organización de Estudios Tropicales organizó un estudio biológico del complejo a principius de 1986. El equipo trabajó en seis puntos de interés a lo largo del corte transversal de elevación establecido por la expedición: $300 \mathrm{~m}, 700 \mathrm{~m}, 1,000 \mathrm{~m}, 1,500 \mathrm{~m}, 2,050 \mathrm{~m}$, y 2,600 m. Nosotros suplementamos nuestros archivos de colección con archivos inéditos puestos a la disposición por colegas, archivos en la literatura publicada, y especímenes en colecciones de museos. Además, se resumen las observaciones anotadas por una variedad de observadores en la Estación Biológica de La Selva.

La fauna mamífera del complejo consiste de 142 especies incluyendo 79 murciélagos, 23 roedores, 13 carnívoros, 7 marsupiales, 6 edentatas, 4 artiodáctilos, 3 monos, 2 conejos, 2 musarañas, y 1 perisodáctilo. Es probable que por lo menos diez especies adicionales se encuentra allí. El único mamífero que probablemente fue extirpado de este área es el oso caballo.

Reconociendo la importancia del área para animales y el género humano en general, el gobierno de Costa Rica añadió 13,500 hectáreas al complejo el 13 de Abril de 1986. Este área, previamente conocido como la "Zona Protectora," suministró el eslabón de la elevación media entre la tierra baja de la Estación Biológica de La Selva y el bosque Montano del Parque Nacional Braulio Carrillo. Desafortunadamente, la destrucción del bosque 
húmedo que circunda cl complejo pronto se transformará en una isla aislada de bosque protejido. Así, el área se volverá cada vez más valiosa como refugio para muchas especies que necesitan espacios grandes en que el habitat no ha sido perturbado.

Costa Rica, with an area of $51,022 \mathrm{~km}^{2}$, is a small country, but one of almost unparalleled biotic diversity. Within the country's borders there are more than 12,000 species of plants, including 1,200 species of orchids and 2,000 tree species. Costa Rica has more than 1,200 species of butterflies, more than are known from all of Africa. There are some 150 species of amphibians and more than 212 species of reptiles. More than 850 species of birds have been found in Costa Rica; this represents $10 \%$ of the world's species and more than have been found in the United States and Canada combined. The native mammal fauna consists of at least 200 species, all of which still can be found within the country's borders. The human population of Costa Rica numbered 2.7 million in 1988 and is increasing at a rate of $2.6 \%$ annually. Predictably, man and nature have come into direct conflict in recent years.

On his fourth and final voyage to the New World in 1502, Christopher Columbus became the first European to land on what the Spanish later termed the "Rich Coast,' Costa Rica. At the time of the Spanish conquest in the early 1500's, primary forests covered an estimated $49,000 \mathrm{~km}^{2}$ or $96 \%$ of the national territory. This land cover consisted of tropical dry forest, tropical moist forest, tropical wet forest, tropical premontane moist forest, tropical premontane wet forest, tropical premontane rain forest, tropical lower montane moist forest, tropical lower montane wet forest, tropical lower montane rain forest, tropical montane wet forest, and tropical montane rain forest (Holdridge 1967; Hartshorn 1983). Remaining land cover may have included tropical subalpine rain paramo and savannah. The extent of indigenous deforestation is unknown, but has been considered minimal. This may not be true however, as there is increasing evidence that rather dense populations of Indians lived in the Atlantic lowlands.

The primary settlers of the northern Caribbean lowlands of Costa Rica were individual families of European descent, the "campesinos." Land was cleared by individuals working with hand tools. Large tracts of intact forest remained in this area as late as the early 1970's. In the late 1970's and early 1980's habitat destruction in this region occurred at a significantly higher rate. This was due in part to increased human population densities and the availability of chain saws. However, perhaps of greater effect were two economic factors: (1) the increased need for and value of lumber as a building material within Costa Rica; and (2) the soaring international market for beef combined with the discovery that African cattle (Zebu, Bos indicus) would prosper in this region when the forest was cleared and introduced grasses planted.

By $1940,15,000 \mathrm{~km}^{2}$ of the forested habitat of Costa Rica had been altered. During the following 37 years, an additional $18,000 \mathrm{~km}^{2}$ was deforested (Sader and Joyce 1988). Thus, more primary forest was destroyed between 1940 and 1977 than during the preceding 400 years (Oficina de Planificación del Sector Agropecuario 1979). By the 1960 's, nearly $50 \%$ of the forest had been destroyed by 
logging and development. Today, less than $30 \%$ of the original forests remain in Costa Rica, and deforestation continues at the rate of 60,000 ha annually. Although reforestation efforts are beginning, most projects are still preliminary and account for less than 4,000 ha annually.

Tropical rain forests are the richest and most complex land biotas. Unfortunately, worldwide, more than half of what was formerly tropical rain forest has been destroyed by modern humans, and the rate of deforestation is increasing. Destruction of tropical forests is causing the extinction of thousands of species, many of them still unknown to science. Worldwide, between $76,000 \mathrm{~km}^{2}$ and $92,000 \mathrm{~km}^{2}$ of forest are being clearcut yearly and an additional $100,000 \mathrm{~km}^{2}$ are being altered severely (Myers 1986). If this deforestation rate continues unchecked, an estimated $50 \%$ of existing tropical forests will be eliminated by the year 2000 (U.S. Department of State 1981). Mankind is losing the potential for the multiple use of these forests as sources of new drugs for medicines, food plants, genetic reservoirs, watersheds, recreational areas, and for sustained utilization of the biota, such as for hunting and logging. Additionally, destruction of large tracts of rain forest may affect continental weather patterns.

Habitat destruction and the associated loss of wildlife are not problems unique to the Caribbean lowlands of Costa Rica, but rather a global problem. It is especially acute in the tropics today as modern technology and demands for resources are putting humans and nature in direct conflict. It has been estimated that $60 \%$ of all species on the earth today will be extinct before scientists have a chance to study them. The establishment of protected reserves and parks, and the expansion of those that already exist, are critical if we are to preserve the flora and fauna of the planet. Nearly everywhere the boundaries of reserves are set by political expediency rather than on the basis of scientific data.

In Costa Rica, the only viable long-term solution for conservation of the biota is protection of remaining habitat and immediate research programs on sustained use. Most remaining forested lands form part of the more than 60 protected wildland areas, the majority of which are under governmental control. The Costa Rican National Parks Service has been outstanding in protecting wildlands, with more than 32 national parks and equivalent biological reserves protecting more than 500,000 ha of land or $12.5 \%$ of the national territory. Additionally, more than $9.6 \%$ of the national territory is protected in a combination of national forests and wildlife preserves and privately owned biological reserves. Unfortunately, the great majority of wildlands in Costa Rica are essentially unknown biologically; an obstacle to their efficient conservation and management. Additionally, many wildland areas are small and located in fragmented habitats; few reserves protect the continuum of altitudinal gradients necessary for survival of many species that migrate seasonally from one elevation to another. Altitudinal gradients also represent a more complete picture of the biota found in a given region.

One such altitudinal reserve was created on 13 April 1986 when Parque Nacional Braulio Carrillo, protecting approximately 31,401 ha of mid- to highelevation forests on the upper slopes of Volcán Barva in Heredia Province, was increased by approximately 13,500 ha with the addition of a wildland area termed 
Zona Protectora 'La Selva' and made part of the Cordillera Volcánica Central Forest Reserve (Fig. 1). Including the 1,500 ha of protected lowland forest of the adjacent privately operated La Selva Biological Station, there now exists a $60-\mathrm{km}$ pro-

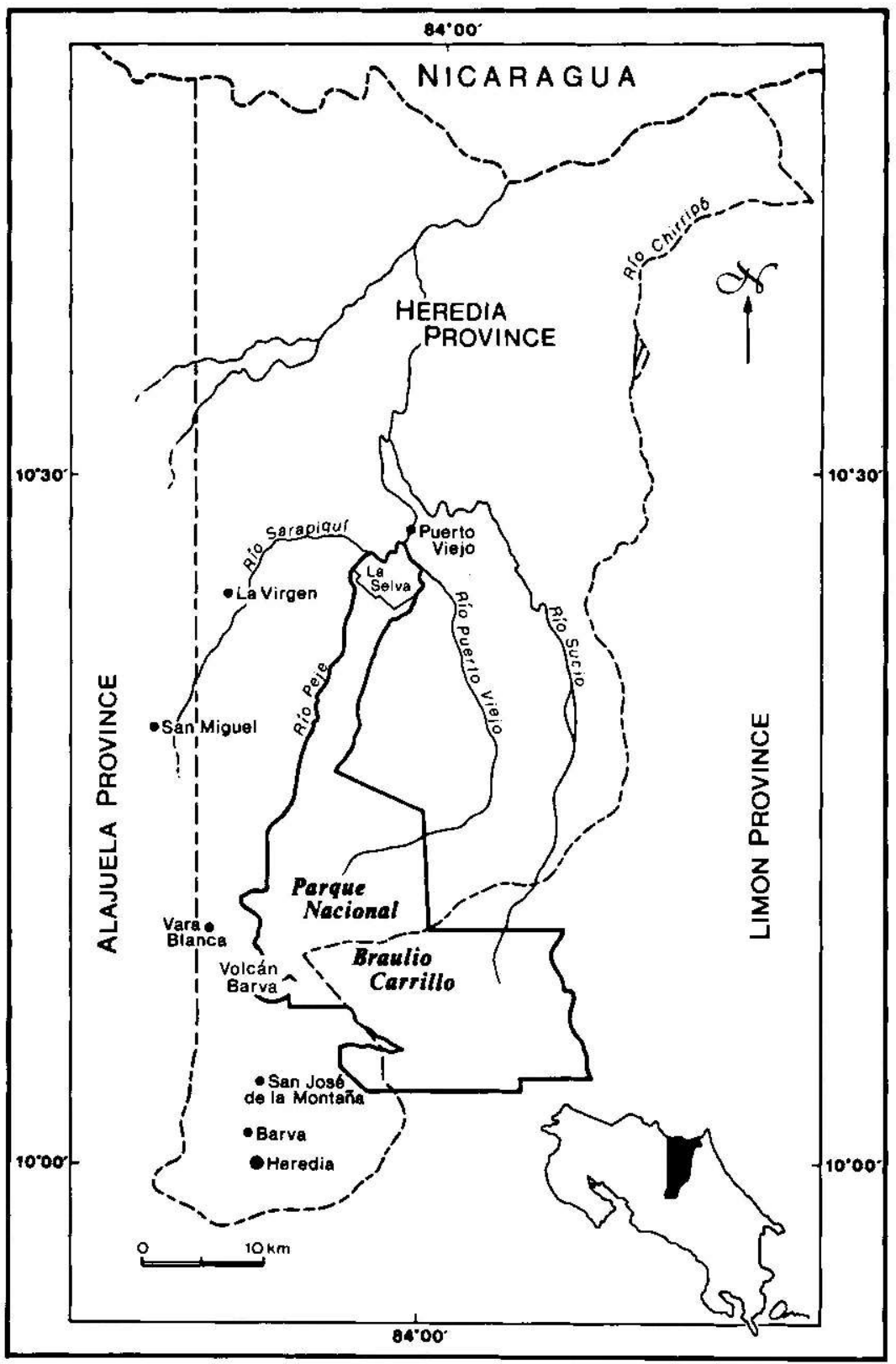

Fig. 1. Map of the study area. 


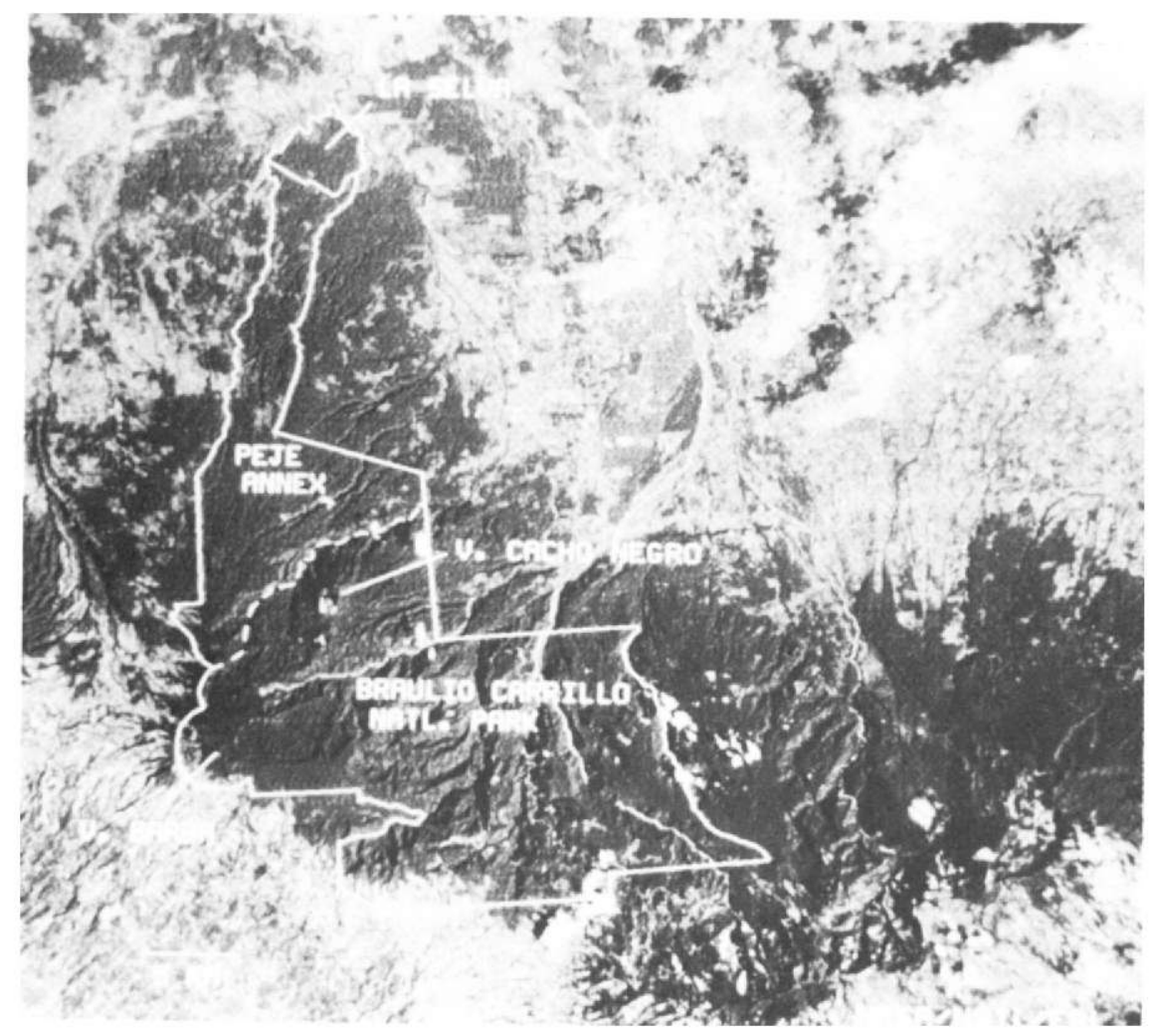

Fig. 2. Satellite photo of the study area. Courtesy of Earth Resources Laboratory, National Space Technology Laboratory, NASA.

tected corridor of forest from $30 \mathrm{~m}$ elevation at La Selva to $2,906 \mathrm{~m}$ at the top of Volcán Barva (Fig. 2). This corridor covers four life zones and two transitional zones between life zones, and is an important route for altitudinal migrants, including at least 35 species of birds. The expansion of Braulio Carrillo extends from the southwestern border of the La Selva Biological Reserve at $100 \mathrm{~m}$ and connects the Atlantic lowland forest around Puerto Viejo to the highlands of Volcán Barva. Together the biological reserve and national park contain 52,000 ha of uninterrupted forest.

Destruction of the rain forest in the Caribbean lowlands has proceeded at such an alarming rate that the two adjacent reserves, La Selva and Parque Nacional Braulio Carrillo, form a virtually isolated island of virgin forest (Fig. 3). The recent extension of the national park to La Selva, forming an elevational transect between the station and the higher elevations of Parque Nacional Braulio Carrillo, will be of vital importance in providing habitat to maintain breeding populations of the larger species with large home ranges that require extensive tracts of undisturbed habitat to maintain population levels, as well as 


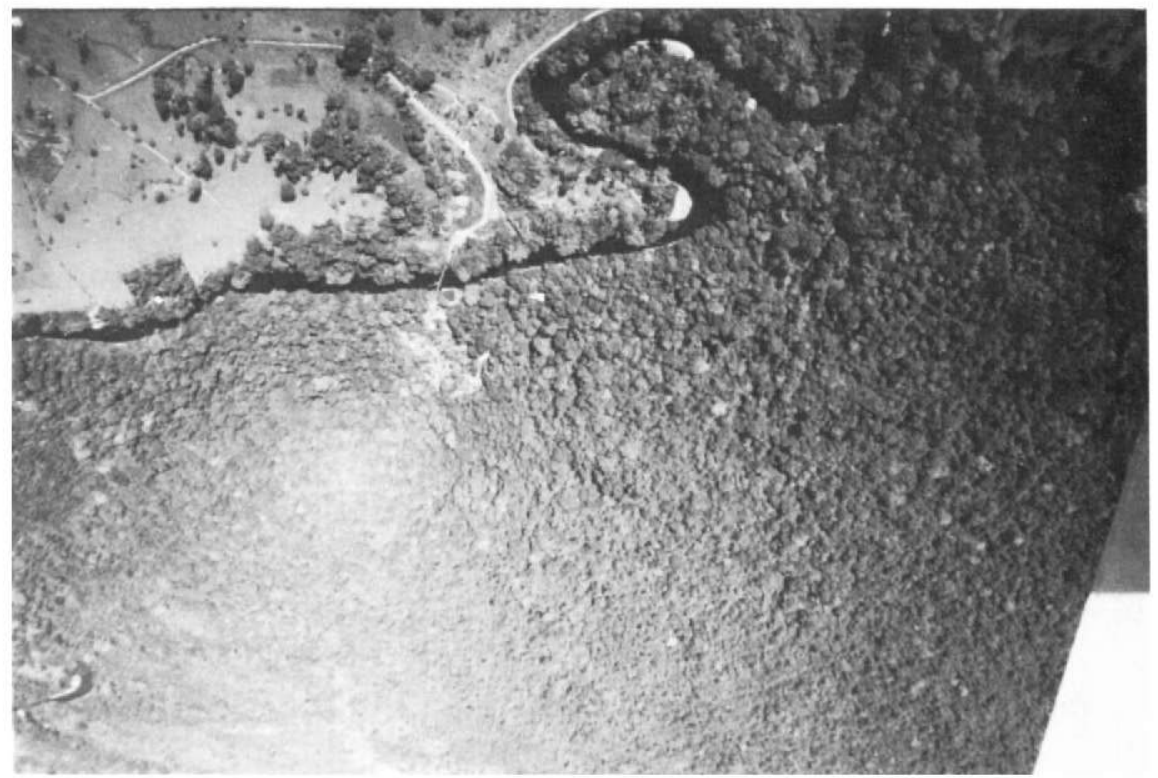

Fig. 3. Aerial photograph of La Selva Biological Station. Cleared area north of Río Puerto Viejo is outside the reserve. Photo by G. S. Hartshorn.

to ensure habitat availability on a seasonal basis for those species that are altitudinal migrants.

Along with Costa Rica's efforts in establishing national parks and wildlife refuges, the country has also afforded significant protection to its wildlife resources through recent enactment of rare and endangered species laws. The following 21 species are included in Costa Rica's listing of Rare and Endangered Species: water opossum (Chironectes minimus), Brazilian free-tailed bat (Tadarida brasiliensis), mantled howler monkey (Alouatta palliata), Geoffroy's spider monkey (Ateles geoffroyi), crested bare-face tamarin (Saguinus oedipus), squirrel monkey (Saimiri oerstedii), three-toed sloth (Bradypus variegatus), giant anteater (Myrmecophaga tridactyla), paca (Agouti paca), Harris' rice rat (Oryzomys aphrastus), mountain squirrel (Syntheosciurus brochus), southern river otter (Lutra longicaudis), mountain lion (Felis concolor), jaguar ( $F$. onca), ocelot $(F$. pardalis), little spotted cat ( $F$. tigrina), margay ( $F$. wiedii), jaguarundi $(F$. yagouaroundi), Baird's tapir (Tapirus bairdii), white-lipped peccary (Tayassu pecari), and manatee (Trichechus manatus). Of these 21 species, at least 15 are, or were, found within the La SelvaBraulio Carrillo complex: water opossum, Brazilian free-tailed bat, mantled howler monkey, Geoffroy's spider monkey, three-toed sloth, giant anteater, paca, southern river otter, mountain lion, jaguar, ocelot, margay, jaguarundi, white-lipped peccary, and Baird's tapir.

The La Selva Biological Station supports a mammalian fauna comprising at least 114 species belonging to 9 orders. Included are 65 bats, 16 rodents, 14 carni- 
vores, 6 edentates, 5 marsupials, 3 primates, 3 artiodactyls, 1 rabbit, and 1 perissodactyl. Although Braulio Carrillo is much more poorly known than La Selva, it is safe to assume that those species of mammals that have been recorded at $\mathrm{La}$ Selva are, or at least were, present in adjacent Braulio Carrillo. If we add to this list the species known to occur in the national park that are not present at La Selva, the fauna of Braulio Carrillo consists of at least 142 species, including 79 bats, 23 rodents, 15 carnivores, 7 marsupials, 6 edentates, 4 artiodactyls, 3 primates, 2 rabbits, 2 shrews, and 1 perissodactyl. This is undoubtedly a conservative estimate because we strongly suspect that additional field work will add to this list (see Species of Possible or Probable Occurrence in the Area). The greater species richness of bats than of all other species combined is not unusual for Neotropical faunas (Findley and Wilson 1983). There are 5 to 10 additional species of bats, a marsupial, and a few rodents that eventually may be found to occur at La Selva. Overhunting before protection of the area likely resulted in the extirpation of giant anteaters and whitelipped peccaries from La Selva. Tapirs, collared peccaries, pacas, agoutis, monkeys, and squirrels probably were reduced in numbers due to hunting pressure before the 1953 purchase of Finca La Selva by L. R. Holdridge. Numbers of these species, along with those of carnivores and rabbits, appear to be increasing in recent years, as protection of wildlife has been a high priority for the current owners, the Organization for Tropical Studies (OTS). Several species of bats and some of the marsupials may have benefited from human activities in the area. Today, the La Selva reserve-Parque Nacional Braulio Carrillo complex, with its elevational extension from near sea level to the top of Volcán Barva at more than $2,900 \mathrm{~m}$, probably contains the best representation of a tropical mammalian fauna found anywhere in Central America (Timm, in press; Wilson, in press).

Most regions of Central America were visited early by educated European explorer-naturalists. These early scientists and dedicated amateurs played a vital, but now often overlooked, historical role in obtaining specimens from remote areas, depositing them in museums where they could be studied by scientists, and in recording observations on natural history and the abundance of organisms before habitat disturbance by expanding human populations. An outstanding example of these naturalists in Central America was the British mining engineer T. Belt, who recorded in great detail his 4 years spent in the Santo Domingo area of central Nicaragua (Belt 1874). He accurately described much of the animal and plant life of the region in addition to the geology. On the South American continent such explorers included Charles Darwin and Alexander von Humboldt.

The first formal collection of mammals from Costa Rica was made by W. M. Gabb during his study of the geography, geology, and paleontology of the lower Talamanca Mountains in 1874 and was sent to the U.S. National Museum of Natural History in Washington, DC. Gabb was employed by M. C. Keith, the builder of the Limón-San José railway, to survey the Talamanca region of Costa Rica for mineral deposits and for possible railway construction routes. Although he was unsuccessful in locating sufficient mineral deposits and a feasible railway construc- 
tion route, he provided an excellent scientific account of the sparsely populated and rugged area, including a reliable report on the region's few remaining Indians, and he made a valuable zoological collection. Gabb's specimens included several new species of mammals, some of which subsequently were described by J. A. Allen. F. Du Cane Godman and O. Salvin produced a multi-volume Biologia Centrali-Americana, beginning in 1879, and one of the early volumes was devoted to mammals (Alston 1879-1882). Alston's book included a table listing the occurrence of each species of mammal in each central American country. His list included 66 species from Costa Rica.

The first checklist devoted strictly to Costa Rican mammals was compiled by the German physician A. von Frantzius (1881). In 1854, at the age of 33, he moved to Costa Rica to improve his health, and opened a drugstore in San Jose that became a center for local naturalists (Gómez and Savage 1983). He made the first significant collection of mammals from the Meseta Central (Central Valley), which he sent to specialists in Germany and the United States for identification and study. His checklist included 56 native species and many others of probable occurrence. Frantzius' assistant, J. C. Zeledón, who under his tutelage later developed an international reputation as an ornithologist, also collected many specimens of mammals that are deposited in the U.S. National Museum of Natural History. Zeledón made considerable contributions to the advancement of science in Costa Rica as a cofounder of the Museo Nacional, collaborator with foreign scientists, teacher, and book collector. The so-called "drugstore gang" included A. Alfaro, the first director of the Museo Nacional in San José, and G. K. Cherrie, a taxidermist who collected many specimens of mammals for that museum and others in the United States. Alfaro (1897) published a checklist of Costa Rican mammals that included 121 species.

The first mention in the literature of mammals from La Selva and the general vicinity was by Slud (1960:76) in The Birds of Finca 'La Selva', Costa Rica, his classic study of the avifauna. Concerning the mammals observed at La Selva during his year's study, he wrote "A howler monkey may roar at any time of day and sometimes night.... Mammals, except agoutis, squirrels, tayras, and monkeys, are seldom to be observed. Of the big cats I saw only tracks."

Students and faculty of the OTS courses have made significant contributions to our understanding of the mammalian fauna of La Selva, and indeed throughout Costa Rica. Shortly after Finca La Selva was purchased by OTS in 1968, we began netting bats there, assisted over the years by the many students in OTS courses. D. E. Wilson was a faculty member and R. K. LaVal was a student in the first course to visit La Selva in 1968. D. M. Armstrong was a student in the second course to visit in 1968 (Armstrong 1969). M. A. Mares visited there in 1969 as a student (Mares and Wilson 1971). Wilson continues to study bats there during OTS courses. LaVal spent several months there in 1973 and 1974 studying bats (LaVal 1977; LaVal and Fitch 1977). R. M. Timm first visited La Selva in 1974 as an OTS student (Foster and Timm 1976; Timm and Mortimer 1976), and has continued to work there and teach with OTS. C. S. Vaughan first visited La Selva 
in 1978 as an OTS student and has continued to work at the station and to bring students from his classes there.

T. H. Fleming studied the rodent fauna in 1970 and 1971 . The number of small mammals, including marsupials, known from La Selva increased greatly during this period (Fleming 1973). At the same time, large mammals were observed more frequently as the number of trained observers increased.

During 1973 and 1974, LaVal sampled the bat fauna intensively using both mist nets and harp traps. His efforts dramatically increased the number of species known to occur at La Selva, several of which were new to the country (LaVal 1977; LaVal and Fitch 1977).

Information on all mammals has continued to accumulate with OTS's continued sponsorship of courses at the site and with the increased number of resident and visiting researchers. A log book is maintained to record mammal sightings, and considerable information has accumulated over the years. Likewise, our knowledge of the entire mammalian fauna of Costa Rica has increased tremendously since Goodwin's (1946) faunal study. Our estimate of the country's terrestrial mammalian fauna is more than 200 species. With 114 species, La Selva contains more than half the mammalian species known to occur in Costa Rica.

A 12-day scientific expedition to the Zona Protectora in 1983 made a preliminary evaluation of the resources there and estimated 800 species of trees and 400 species of birds. The expedition recorded 17 species of frogs and toads, 27 species of reptiles, and 18 species of mammals. Expedition members found 28 new plant species and 12 others not previously known from Costa Rica (Pringle et al. 1984).

With this information in hand, a more extensive expedition organized by the Organization for Tropical Studies began on 25 March 1986 and covered a transect from the La Selva Biological Station to the top of Volcán Barva (Fig. 1). The team of researchers included mammalogists, botanists, entomologists, herpetologists, invertebrate zoologists, and ornithologists, who studied various aspects of the biological richness and uniqueness of this area. This report covers only the mammal survey, the objectives of which were to determine general distributions and relative abundances of mammal species along the altitudinal transect between La Selva $(30-137 \mathrm{~m})$ and Volcán Barva $(2,906 \mathrm{~m})$.

We have not addressed the biogeographic affinities of this mammalian fauna since several recent reviews treat the biogeography of Costa Rican mammals from a variety of perspectives. Timm (in press) and Wilson (in press) treat the biogeographic relations of the mammalian fauna of La Selva, McPherson $(1985,1986)$ discusses the biogeography of Costa Rican rodents, and Savage (1974) provides an interesting review of the Isthmian Link and the evolution of Neotropical mammals. 


\section{Study Sites}

Tropical wet forest on the Caribbean slopes of Costa Rica is found from sea level to about $150 \mathrm{~m}$. Tropical wet forest cool-transition changes at 250 to $300 \mathrm{~m}$ to tropical premontane wet-transition rain forest, which is found from 300 to $500 \mathrm{~m}$. Tropical premontane rain forest, from 500 to $1,500 \mathrm{~m}$, lower montane rain forest, from 1,500 to 2,500 m, and montane rain forest, from 2,500 to 2,906 m, make up the other life zones found in Parque Nacional Braulio Carrillo.

The team of mammalogists on the 1986 expedition worked out of six camps situated at roughly $300 \mathrm{~m}, 700 \mathrm{~m}, 1,000 \mathrm{~m}, 1,500 \mathrm{~m}, 2,050 \mathrm{~m}$, and $2,600 \mathrm{~m}$ (Fig. 1). We began at the 300-m site and spent 4-7 days at each site before moving up to the next camp. Censusing of larger mammals was done along the main trails at each study site by searching for animals and their signs (tracks, droppings, and so forth). Information was gathered from La Selva Biological Station $(30-137 \mathrm{~m})$ based on our previous knowledge of the site and the logbook of mammal sightings kept by staff, students, and researchers.

The first site $\left(10^{\circ} 22^{\prime} \mathrm{N}, 84^{\circ} 03^{\prime} \mathrm{W}\right)$, which contained an abandoned farm and logging operation, was in a valley along the Río Cantarrana from 270 to $300 \mathrm{~m}$, $11 \mathrm{~km}$ south and $4.5 \mathrm{~km}$ west of Puerto Viejo. The thick vegetation consisted of introduced weeds on the valley floor near the buildings; trees included Cecropia, Ochroma lagopus, and Welfia georgii. Primary and secondary forest was found about 200 to $300 \mathrm{~m}$ outside of the camp site and enclosed it on three sides. Mean annual rainfall for this area is estimated at $4,000 \mathrm{~mm}$. Key tree species found in the forest at this elevation included Minquartia guianensis and Pentaclethra macroloba. Trap lines were placed along the main trail in primary forest, along streams, and in abandoned pasture; mist nets were placed in the first two environments.

The $700 \mathrm{~m}$ site was in pasture adjacent to the Río Cascante, $1 \mathrm{~km}$ south and $11.5 \mathrm{~km}$ east of San Miguel de Sarapiquí $\left(10^{\circ} 18^{\prime} \mathrm{N}, 84^{\circ} 05^{\prime} \mathrm{W}\right)$. In abandoned pasture, we found shrubs and dense grass, and isolated individual trees that remained from earlier clearing. Primary forest was found adjacent to the camp site. Rainfall at this tropical premontane rain forest site could be as much as $4,500 \mathrm{~mm} /$ year. Key tree species found in the forest at this elevation include Carapa guianensis and Terminalia amazonia. Traps were set along the main trail in primary forest, along streams, and in pasture; mist nets were placed in the first two situations.

The third site was in primary forest at $1,000 \mathrm{~m}, 3.5 \mathrm{~km}$ south and $11.5 \mathrm{~km}$ east of San Miguel $\left(10^{\circ} 17^{\prime} \mathrm{N}, 84^{\circ} 05^{\prime} \mathrm{W}\right)$ along the Río San Rafael. This site was surrounded by virgin tropical premontane rain forest. Both traps and mist nets were set along the trails and streams.

The $1,500-\mathrm{m}$ site was located $9 \mathrm{~km}$ south and $11.5 \mathrm{~km}$ east of San Miguel $\left(10^{\circ} 14^{\prime} \mathrm{N}, 84^{\circ} 05^{\prime} \mathrm{W}\right)$. It was in primary forest within the lower montane life zone. Key tree species at this elevation included Ocotea austinii and Quercus corrugata. The site was noticeably wetter, had a lower canopy, more saturated soils, and 
heavier moss growth than we found at the lower elevations. We set traps and mist nets along the main trail at the $1,000-\mathrm{m}$ and $1,500-\mathrm{m}$ sites.

The fifth study site $\left(10^{\circ} 01^{\prime} \mathrm{N}, 84^{\circ} 07^{\prime} \mathrm{W}\right)$, at $2,050 \mathrm{~m}$, was situated in an abandoned pasture $5 \mathrm{~km}$ east of Vara Blanca. Traps and mist nets were placed in the nearby primary forest along the main trail and along a small stream. Landslides seemed common at this elevation, probably caused by unstable soils, steep slopes, and high rainfall. Key tree species at this elevation again included Ocotea austinii and Quercus corrugata.

We used a guard station located $2 \mathrm{~km}$ north and $0.5 \mathrm{~km}$ east of Sacramento for camp at 2,600 m. It is on the Pacific side of Volcán Barva, and the nearby habitats are mostly pasture and several successional stages of forest. This site is within the montane rain forest life zone. Key tree species included Drymys winterii and Quercus costaricensis. Traps and mist nets were set along the road and in pastures found between forest patches.

The La Selva Biological Station is the field station of the Organization for Tropical Studies located $3 \mathrm{~km}$ south of Puerto Viejo de Sarapiquí $\left(10^{\circ} 27^{\prime} \mathrm{N}\right.$, $84^{\circ} \mathrm{O0}{ }^{\prime} \mathrm{W}$ ); elevation ranges from 35 to $135 \mathrm{~m}$. Mean annual rainfall is $3,990 \mathrm{~mm}$, with the wettest months being November, December, and February; mean monthly temperatures range from $24.5^{\circ} \mathrm{C}$ (December) to $26.1^{\circ} \mathrm{C}$ (April). La Selva lies within the tropical wet forest zone and grades into tropical premontane wet forest, with lowland evergreen forest the dominant forest type. Vegetation and habitat types of La Selva have been described by Slud (1960), Holdridge et al. (1971), Sawyer and Lindsey (1971), Hartshorn (1983), D. Lieberman et al. (1985), and M. Lieberman et al. (1985). One unusual fegture of the subcanopy of the La Selva forest is the diversity and abundance of dwarf palms (Hartshorn 1983), especially the broad-leaved species, Geonoma congesta and Asterogyne martiana. The fruits and seeds of these palms serve as food for small mammals and the leaves are used by Dermanura watsoni for tent construction. The forest at La Selva is complex with perhaps as many as 400 species of trees; however, Pentaclethra macroloba (Mimosaceae) is the dominant tree species. Because of possible errors in identification by untrained observers, logbook notations from La Selva were screened by us. We have included only those reports that we believe to be reliable, unless otherwise discussed in the species accounts.

The habitat types along the La Selva-Volcán Barva altitudinal transect were described in greater detail by Hartshorn and Peralta (1988). 


\section{Specimen Data}

Each species of mammal presently or historically recorded from Heredia Province, Costa Rica, as well as those possibly occurring there but whose presence is unverified by specimens, is treated separately in the accounts that follow. The basis of each species account is the natural history data obtained during this study, including distribution, relative abundance, reproductive characteristics, habitat use, parasites, food habits, and taxonomic comments as appropriate. All known records from the province and references to pertinent literature are included.

The colloquial or vernacular name(s) for each species is listed in English and then in Spanish immediately following the scientific name heading each species account. Spanish names listed herein are those used within this region of Costa Rica. Colloquial names for mammals often vary from country to country and even between different regions of the same country. Although there is little variation within Costa Rica in colloquial names for easily observed mammals, these are sometimes different than names used in neighboring countries. For example, in Costa Rica tigrillo refers to the gray fox (Urocyon cinereoargenteus), whereas in most Latin American countries tigrillo can refer to the margay (Felis wiedii). In Costa Rica, zorro refers to either of the two species of skunks that occur there, whereas in many Spanish speaking countries zorro refers to foxes. Agouti paca is a common game species throughout the tropics; in Costa Rica, and in adjacent Nicaragua, it is known as the tepezcuintle, but this name is not used everywhere in Latin America. The word is derived from the Indian name for the species. As nonmammalogists cannot distinguish most of the many species of bats, there are few local colloquial names in Spanish for bat species other than those that are direct translations of the English common name. Thus, we have not included Spanish names for most of the bats.

Standard external measurements (total length, length of tail vertebrae, length of hind foot, and height of ear from notch) were recorded in millimeters, weight was recorded in grams. On the basis of size and pelage characteristics, each animal was placed into one of three age classes: juvenile, subadult, or adult.

Specimens listed under "Specimens examined" were personally examined by one or more of us. The localities listed in both the "Specimens examined" and "Additional records" sections are reported as they were recorded by the original collector on specimen labels. Many specimens dating from the 1960's have distances recorded in miles and elevation in feet. Accordingly, we have kept the original English measures rather than convert these measures to metric equivalents. The one exception to maintaining the original locality data is that we have standardized the locality for specimens taken from La Selva. As the name for and formal status of this property have varied over the years, herein we use the name that has been most frequently associated with specimens in collections, "Finca La Selva, $3 \mathrm{~km}$ S of Puerto Viejo." Specimens preserved from the 1986 Zona Protectora Expe- 
dition were divided between the Universidad Nacional de Costa Rica (a representation of the species collected), Field Museum of Natural History (primarily marsupials and rodents), and U.S. National Museum of Natural History (primarily bats). Specimens listed under "Additional records" either were taken from the literature or, for one reason or another, were not examined by one of us. In some cases, specimen identifications and localities were provided to us by curators of the collections in which they were housed, and we have not verified their identifications. The order for listing specimens is according to locality of capture as follows: alphabetical by reference point, then sequential north to south; those from the same latitude referenced to the same point are in order west to east. Sight records are so listed in the individual species accounts and we included these only when we were quite certain a correct identification was made. The arrangement of orders and families follows Hall (1981). Genera and species within a genus are treated in alphabetical order. Abbreviations designating specimens housed in museum collections are as follows:
AMNH American Museum of Natural History, New York
CAL California Academy of Sciences, San Francisco
CM Carnegie Museum of Natural History, Pittsburgh
FMNH Field Museum of Natural History, Chicago
KU Museum of Natural History, University of Kansas, Lawrence
LACM Natural History Museum of Los Angeles County, Los Angeles
LSUMZ Louisiana State University Museum of Zoology, Louisiana State Univer- sity, Baton Rouge
MNCR Museo Nacional de Costa Rica, San José
MSB Museum of Southwestern Biology, University of New Mexico, Albuquerque
MVZ Museum of Vertebrate Zoology, University of California, Berkeley
TCWC Texas Cooperative Wildlife Collection, Texas A\&M University, College Station
TTU The Museum, Texas Tech University, Lubbock
UCR Universidad de Costa Rica, San José
UMMZ Museum of Zoology, University of Michigan, Ann Arbor
UNA Universidad Nacional de Costa Rica, Heredia
USNM United States National Museum of Natural History (including collec- tions of the United States Biological Survey)

\section{Accounts of Species}

In the following accounts of mammals from the La Selva Biological ReserveParque Nacional Braulio Carrillo elevational transect, 142 species belonging to 10 orders and 32 families are included on the basis of documentation of their occurrence in Heredia Province. In addition, one species is considered as extirpated from the region, and comments are made concerning five species that may occur 
or have occurred in the past within the province, but whose presence there lacks adequate documentation.

\title{
Species of Verified Occurrence
}

\section{ORDER MARSUPIALIA}

\author{
Family Didelphidae \\ Caluromys derbianus \\ Woolly Opossum, Zorro de Balsa
}

Woolly opossums are found from southern Mexico south through western Colombia and extreme northwestern Ecuador (Fig. 4). Two subspecies of Caluromys derbianus are recognized in Costa Rica; $C$. derbianus centralis from the eastern slopes and lowlands and $C$. derbianus pallidus from the western slopes and lowlands. They are found from sea level to about $1,600 \mathrm{~m}$. The biology of woolly opossums was reviewed by Bucher and Hoffmann (1980).

Woolly opossums have been observed at La Selva on at least 12 occasions. One was seen eating the fruits of Piper near the field station in July 1984. We examined an adult male woolly opossum (testes measured $11 \times 9 \mathrm{~mm}$ ) found dead on the Southwest Trail at La Selva on 25 March 1986. Another adult male was electrocuted on the wires behind the laboratory building on 20 January 1987.

Specimen examined (1)-Finca La Selva, $3 \mathrm{~km} \mathrm{~S}$ of Puerto Viejo, $70 \mathrm{~m}$ [1 male, FMNH].

Fig. 4. Woolly opossum, Caluromys derbianus. Photo by R. K. LaVal.

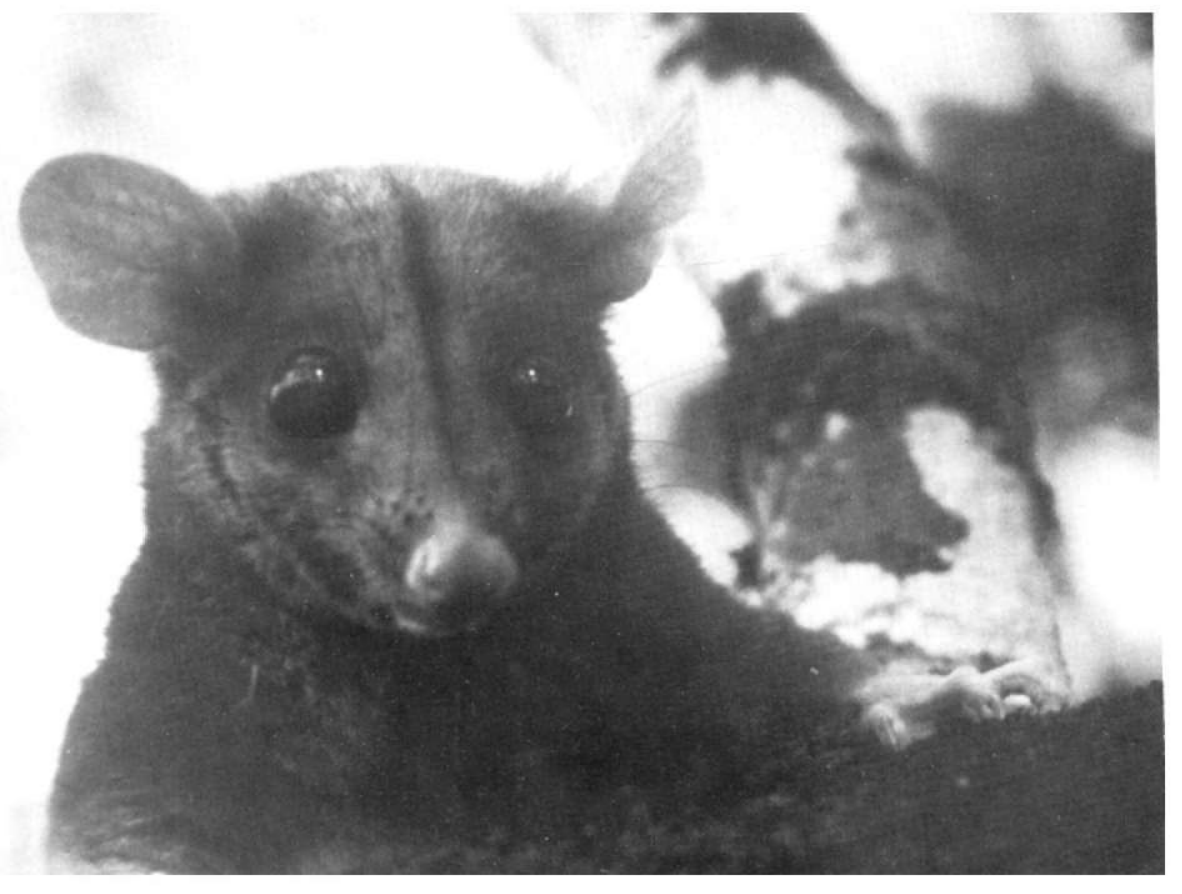




\section{Chironectes minimus Water Opossum, Zorro de Agua}

Water opossums are found from southern Mexico south through Central America to the Amazon and Orinoco river basins in South America (Fig. 5). One subspecies, Chironectes minimus panamensis, is found throughout the wet tropical lowlands of Costa Rica, although few specimens exist. Water opossums are found at least as high as $1,300 \mathrm{~m}$ in Costa Rica although their numbers and distribution have been reduced due to the degradation in quality of many streams. The biology of this species was reviewed by Marshall (1978).

One C. minimus was observed swimming in the Río Cantarrana near the 300-m base camp in April 1986, and another was seen in the same area in January 1983 (Pringle et al. 1984). Water opossums have been reported only seven times at La Selva between February 1979 and August 1988.

Specimen examined (1)-Puerto Viejo, Río Sarapiquí, 300 ft [1 male, UMMZ].

\section{Didelphis marsupialis \\ Southern Opossum, Zorro Pelón or Zarigüeya}

The southern opossum is widespread throughout the Central and South American lowlands (Fig. 6). In Costa Rica it is found country-wide except at higher elevations in the Cordillera Central and the Talamanca Mountains. In a revision of the Didelphis of Central and North America, Gardner (1973) recognized only a single subspecies of $D$. marsupialis from Mexico and Central America, D. m. caucae. Hall (1981), however, listed six subspecies of $D$. marsupialis from Central America, recognizing $D$. $m$. richmondi from extreme southeastern Nicaragua and northeastern Costa Rica in addition to $D . m$. caucae from the rest of the country. We concur with Gardner that $D$. m. richmondi is not a distinct subspecies, and that all $D$. marsupialis from Costa Rica should be considered $D$. m. caucae. The biology of D. marsupialis was reviewed by Gardner (1983a).

We saw opossums on numerous occasions at $200,300,680$, and $750 \mathrm{~m}$, although most often at $680 \mathrm{~m}$. They are reported frequently near the La Selva Biological Station. In July 1974 we found an adult female opossum with five pouch young near the La Selva field station, on 3 July 1986 an adult female and four young were observed there, and on 8 July 1988 an adult female and two young were observed. Vaughan captured $D$. marsupialis at least 15 times at La Selva in live traps baited with chickens, meat, and fish and set for small wild felids in 1984-85. In this area, opossums are found in both forest and clearings. Pringle et al. (1984) reported D. marsupialis near their Cantarrana base camp in Parque Nacional Braulio Carrillo at $300 \mathrm{~m}$ in June of 1983.

External measurements for two adult males and one adult female we captured are as follows: total length, $790 \mathrm{~mm}, 840 \mathrm{~mm}, 818 \mathrm{~mm}$; length of tail, $401 \mathrm{~mm}$, $460 \mathrm{~mm}, 416 \mathrm{~mm}$; length of hind foot, $67 \mathrm{~mm}, 65 \mathrm{~mm}, 67 \mathrm{~mm}$; height of ear from notch, $54 \mathrm{~mm}, 55 \mathrm{~mm}, 55 \mathrm{~mm}$. Testes on the two males measured $22 \times 12 \mathrm{~mm}$ and $19 \times 11 \mathrm{~mm}$. 


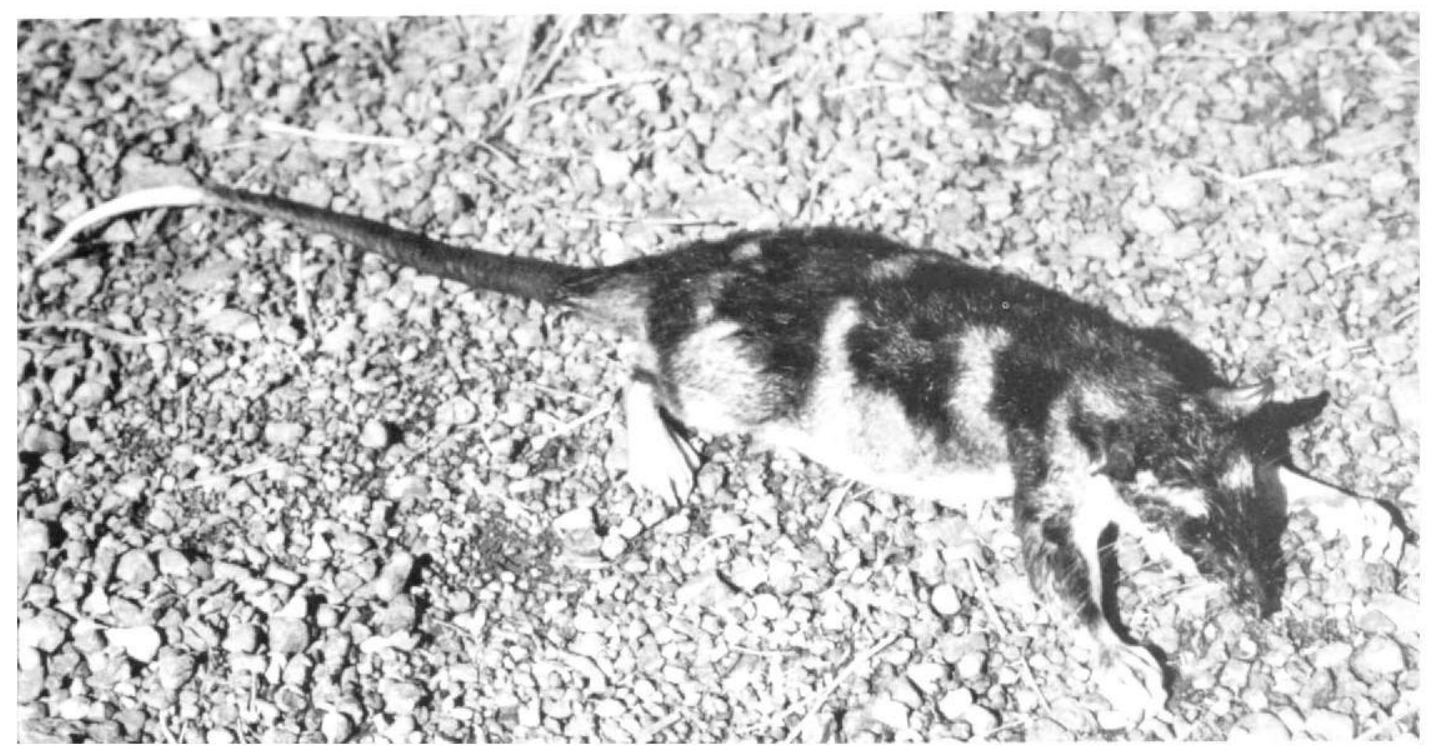

Fig. 5. Water opossum, Chironectes minimus. Photo by $R$. W. McDiarmid.

Ectoparasites found on D. marsupialis include two species of ticks, Amblyomma sp. (11 larvae, 3 nymphs) and Ixodes luciae ( 2 males). This represents the first record of 1 . Luciae, a Neotropical opossum tick, from Costa Rica.

Specimens examined (3)-1 km S, $11.5 \mathrm{~km}$ E of San Miguel, $680 \mathrm{~m}$ [2 males, 1 female, FMNH].

Fig. 6. Southern opossum, Didelphis marsupialis. Photo by A. L. Gardner.

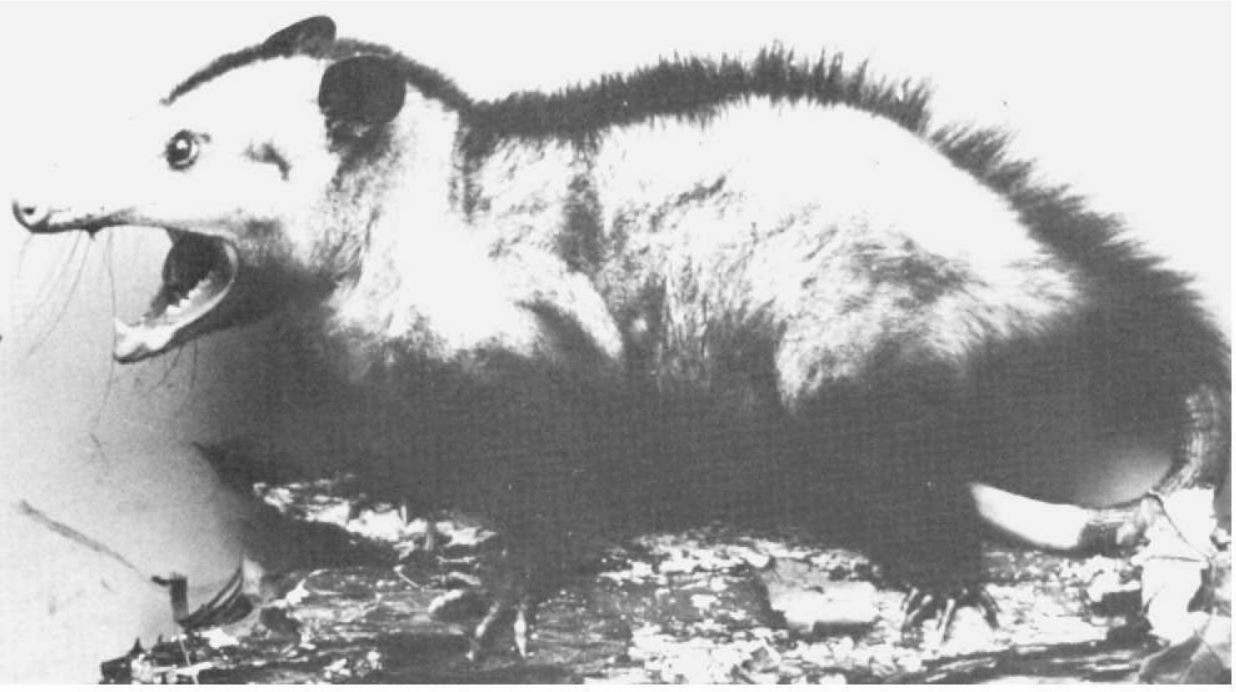




\section{Marmosa alstoni \\ Alston's Opossum, Zorra or Zorricí}

Alston's opossum, Marmosa alstoni, is found in the Caribbean lowlands and adjacent mountain slopes from Belize to southeastern Costa Rica and in Colombia (Fig. 7). Marmosa alstoni is considered by some to be a subspecies of the widely distributed South American species, $M$. cinerea. In Costa Rica, Alston's opossum ranges from sea level to about $1,600 \mathrm{~m}$. Although little has been published about the biology or distribution of this species, it is relatively common in appropriate habitats. Vaughan had a group of $M$. alstoni living in his house near Concepción at $1,500 \mathrm{~m}$, which is just outside of Parque Nacional Braulio Carrillo. There are no records of this species from La Selva or Braulio Carrillo, but we suspect that it occurs in the park.

Specimen examined (1)-1 km NW of Concepción de San Rafael, 1,500 m [1 sex?, UNA].

Marmosa mexicana

Mexican Mouse-opossum, Zorra or Zorricí

Mexican mouse-opossums are found from eastern and southern Mexico to western Panama (Fig. 8). The subspecies Marmosa mexicana zeledoni is found throughout Costa Rica.

Marmosa mexicana has been seen or taken at La Selva on several occasions, although there are no previously published records of this diminutive opossum from the region. The first specimen from La Selva was a male collected by Casebeer and Starrett in the early 1960's (LACM 24121). The second specimen is a subadult female collected by LaVal on 5 February 1974 (KU 134859). Collett captured a $M$. mexicana between the 3- and 4-year-old successional plots at La Selva in summer 1975, and Anderson caught another in a live trap baited with banana there in July 1983; both were released. We have found skulls and jaws of $M$. mexicana in regurgitated pellets of the spectacled owl (Pulsatrix perspicillata) at La Selva on several occasions. No other evidence of small mammals was found in these pellets, suggesting that mouse opossums compose a significant portion of the diet of spectacled owls there, at least during the rainy season (when the pellets were found). Although there are few records of Mexican mouse-opossums from La Selva, it is likely that they are more common there than the records indicate. They are nocturnal, arboreal, secretive, and seldom observed. Systematic trapping and study of remains found in owl pellets are a much better indicator of their presence and density than are sight observations.

We collected juvenile, subadult, and adult Mexican mouse-opossums in late March and early April in Parque Nacional Braulio Carrillo. Testes measurements of two adult males were $10 \times 6 \mathrm{~mm}$ and $8 \times 6 \mathrm{~mm}$. A single nymph of lxodes venezuelensis was collected on $M$. mexicana and represents the first record of this tick on the Mexican mouse-opossum.

Specimens examined (14)-Finca La Selva, $3 \mathrm{~km} \mathrm{~S}$ of Puerto Viejo [1 female, $\mathrm{KU} ; 1$ male, LACM]; $11 \mathrm{~km} \mathrm{S,} 4.5 \mathrm{~km}$ W of Puerto Viejo, $270 \mathrm{~m}$ [1 male, UNA], $325 \mathrm{~m}$ [6 males, 2 females, FMNH; 1 male, UNA], and $340 \mathrm{~m}$ [1 sex?, FMNH]; $1 \mathrm{~km} \mathrm{~S}, 11.5 \mathrm{~km} \mathrm{E}$ of San Miguel, $710 \mathrm{~m}$ [1 male, FMNH]. 


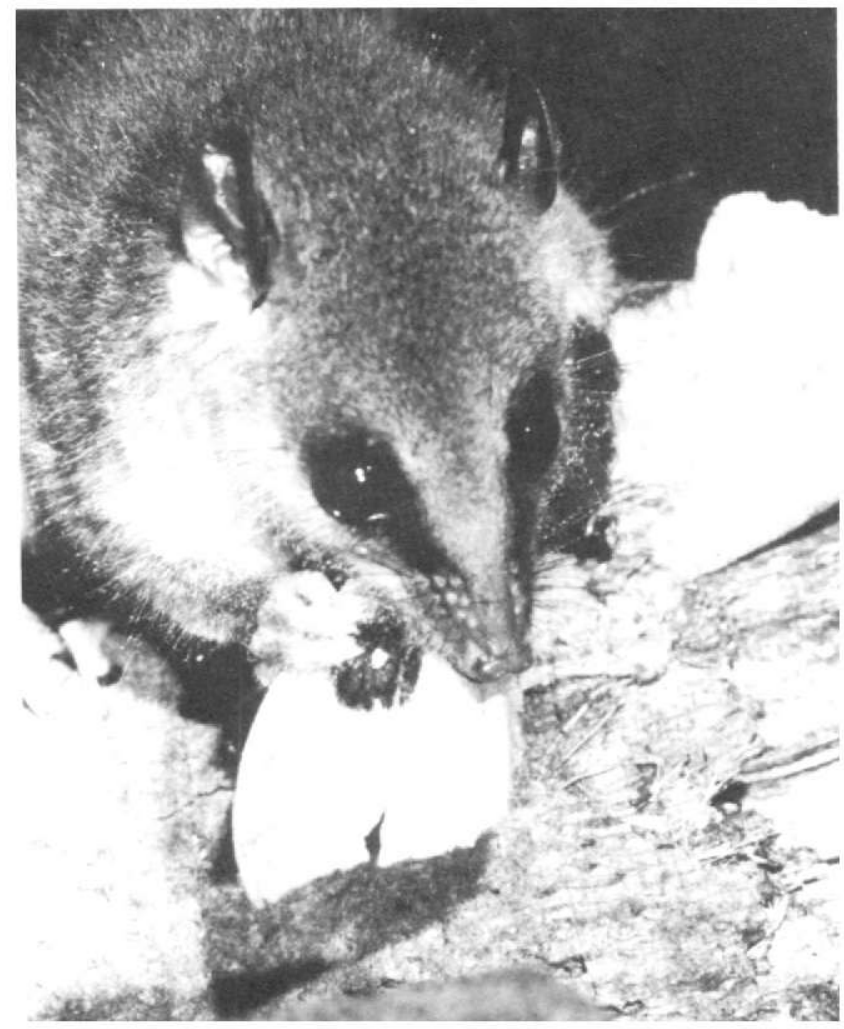

Fig. 7. Alston's opossum, Marmosa alstoni. Photo by R. K. LaVal.

Fig. 8. Mexican mouse-opossum, Marmosa mexicana. Photo by B. L. Clauson.

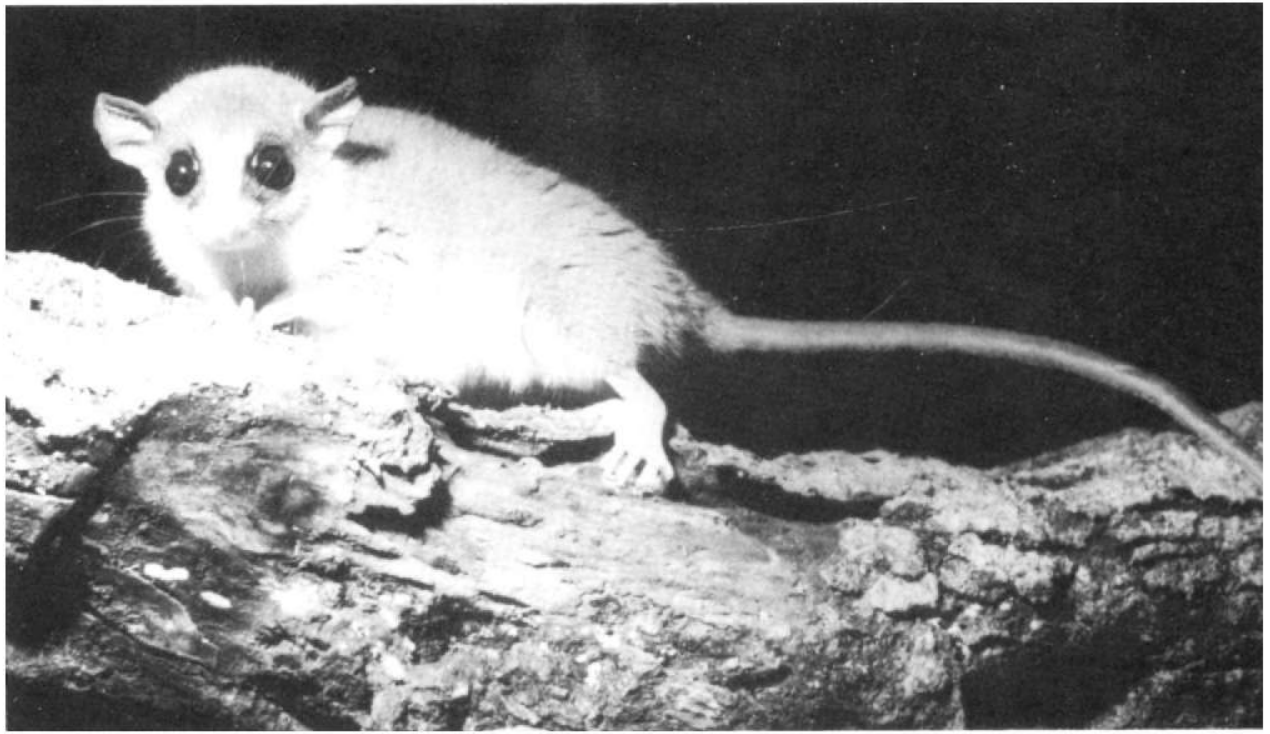




\section{Metachirus nudicaudatus \\ Brown Four-eyed Opossum, Zorro de Cuatro Ojos}

Brown four-eyed opossums are found from southeastern Nicaragua through much of South America to northern Argentina. Although Hall (1981) suggested that the range of brown four-eyed opossums included all of Costa Rica, until recently no specimens had been reported in the literature from Costa Rica. McPherson et al. (1985) noted that one specimen was collected at Angostura, near Turrialba in Cartago Province in 1876, and that for more than a century it went unrecognized as being the only specimen of Metachirus nudicaudatus from the country. They also reported a second specimen collected near Sarapiquí in Heredia Province in 1983. These specimens are from $600 \mathrm{~m}$ and $200 \mathrm{~m}$, respectively, both from the Caribbean slopes.

Several individuals have recorded observations of animals they considered to be $M$. nudicaudatus at La Selva over the years. We believe that most, if not all of these observations were actually sightings of gray four-eyed opossums (Philander opossum). Although $M$. nudicaudatus and $P$. opossum are similar in size (Metachirus is slightly smaller) and appearance, they are not particularly closely related. The only field character useful in separating these two species is that Metachirus, as its common name implies, is various shades of brown, whereas Philander, as its common name implies, is various shades of gray. These two species are difficult to distinguish in the field, especially at night under poor light. The use of the name $M$. nudicaudatus for all four-eyed opossums at La Selva seems to be based on a 1960's handwritten list of the mammals occurring there, where the species is listed as the only four-eyed opposum of the region. It seems likely that subsequent observers applied this name to any four-eyed opossums they observed, even though Philander is actually more abundant and thus more likely to be observed. Given the apparent rarity of $M$. nudicaudatus in Costa Rica, it would be extremely valuable to have additional specimens of four-eyed opossums available for study.

Additional record (1)-Sarapiquí, Finca Cantarrana, near Río Peje, $200 \mathrm{~m}$ [1 male, MNCR-McPherson et al. 1985].

\section{Philander opossum Gray Four-eyed Opossum, Zorro de Cuatro Ojos}

Gray four-eyed opossums are found from eastern Mexico south throughout Central America and much of tropical South America (Fig. 9). The subspecies Philander opossum fuscogriseus is found in Costa Rica from sea level to about $1,600 \mathrm{~m}$.

On 14 April, an adult male $P$. opossum was captured crossing a fallen log near the Río Cascante at $680 \mathrm{~m}$. External measurements for this male are: total length, $625 \mathrm{~mm}$; length of tail, $310 \mathrm{~mm}$; length of hind foot, $48 \mathrm{~mm}$; height of ear from notch, $40 \mathrm{~mm}$; weight, $605 \mathrm{~g}$; testes measured $15 \times 10 \mathrm{~mm}$.

A fresh partial skull of a second adult $P$. opossum was found along the Río Cascante at $680 \mathrm{~m}$; it appeared that the animal recently had been consumed 


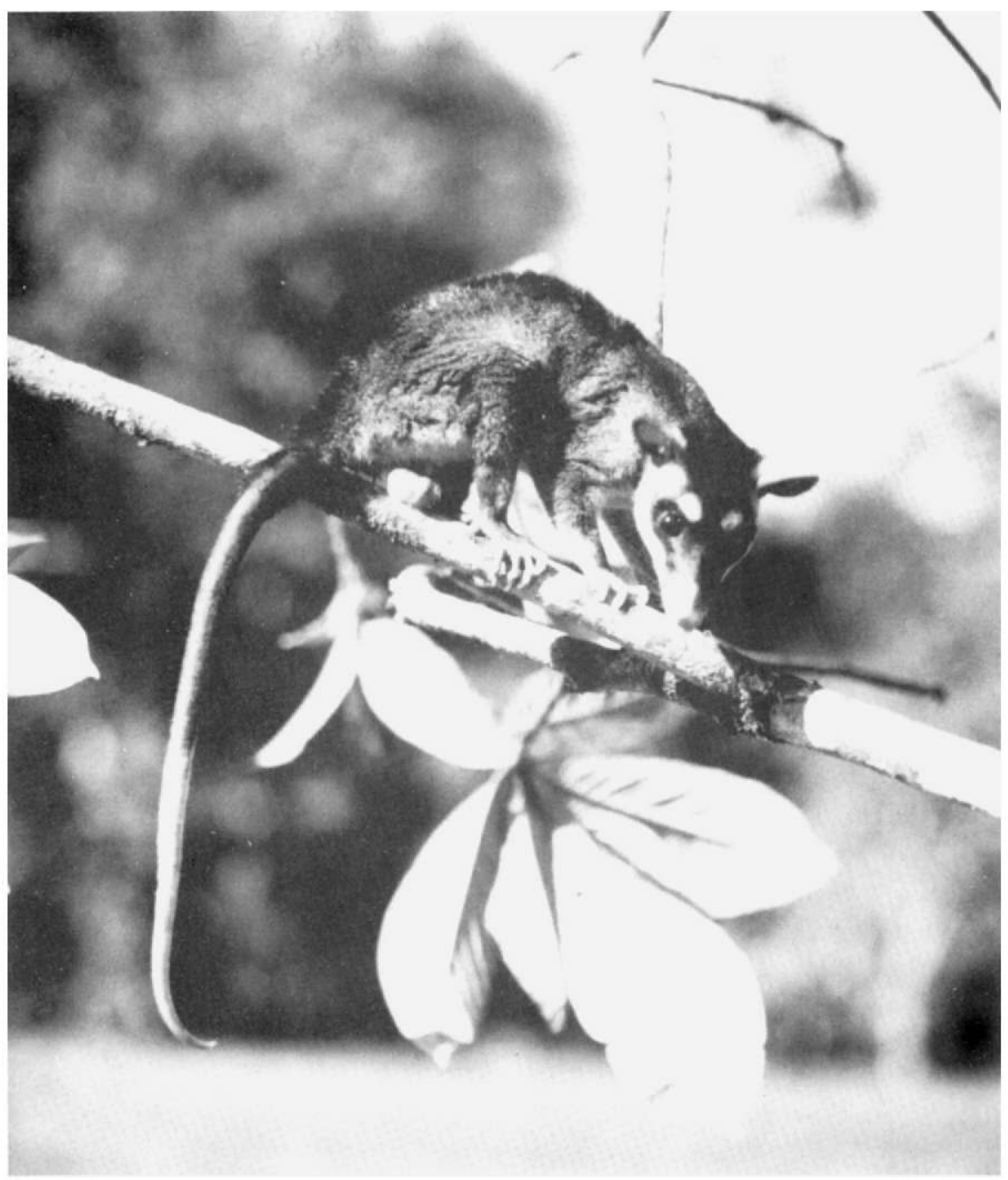

Fig. 9. Gray four-eyed opossum, Philander opossum. Photo by B. L. Clauson.

by a predator. On the evening of $30 \mathrm{March}$, a $P$. opossum was seen at $1.5 \mathrm{~m}$ height in a bush adjacent to the Río Cantarrana at $280 \mathrm{~m}$. Four-eyed opossums were reported eight times near La Selva between February 1979 and April 1988 (see account of Metachirus nudicaudatus).

Ticks found on $P$. opossum include Amblyomma sp. (one nymph) and Ixodes venezuelensis (one nymph). Ixodes venezuelensis, a species in which males are unknown, is herein reported in Costa Rica for the first time based on this specimen and on our single specimen from $M$. mexicana.

Specimens examined (3)-Puerto Viejo, Río Sarapiquí, $300 \mathrm{ft}$ [1 male, UMMZ]; $1 \mathrm{~km} \mathrm{S,} 11.5 \mathrm{~km} \mathrm{E}$ of San Miguel, $680 \mathrm{~m}$ [1 male, $1 \mathrm{sex}$ ?, FMNH]. 


\title{
ORDER INSECTIVORA
}

\author{
Family Soricidae \\ Cryptotis parva \\ Least Shrew, Musaraña
}

Least or small-eared shrews of the genus Cryptotis are widely distributed in eastern North, Central, and northern South America. The most widely distributed species, C. parva, is distributed in eastern North America from southern Canada through Mexico and Central America to the Chiriquí highlands of western Panama. Although there are only a few specimens of Cryptotis parva known from Heredia Province, we suspect that it is a common and abundant species on the western slope of Volcán Barva in the Meseta Central. A single subspecies of $C$. parva, C. $p$. orophila was recognized by Choate (1970) as occurring in Costa Rica.

The specimens from San José de la Montaña were captured in a home during the months of September through November. The specimens from San Miguel de la Montana were taken by house cats in an area that included small fincas and houses, but little natural vegetation.

Specimens examined (6)-San José de la Montaña, ca. 1,800 m [1 male, 2 females, KU]; San Miguel de la Montaña, 1,690-1,700 m [1 male, 2 females, $\mathrm{KU}$.

\section{Cryptotis sp. \\ Least Shrew, Musaraña}

A single, long-tailed Cryptotis was captured in a pasture above Alto del Roble northeast of Heredia, at $2,080 \mathrm{~m}$ by E. T. Hooper on 28 July 1968. He captured this adult male shrew in a snap-trap baited with peanut butter and set in a stump. It was originally identified as $C$. gracilis, and was reported as that species by Choate (1970) and Hall (1981). It clearly is related to that species; however, it may represent an undescribed taxon. This specimen currently is under study by N. Woodman and R. Timm.

Specimen examined (1)-Alto del Roble, $11 \mathrm{~km} \mathrm{NNE}$ of Heredia, 2,080 m [1 male, UMMZ].

\section{ORDER CHIROPTERA}

\section{Family Emballonuridae \\ Centronycteris maximiliani Thomas' Bat}

Thomas' bats are found from Veracruz, Mexico, south through Peru and Brazil (Fig. 10). The genus is monotypic (Husson 1978). Although Thomas (1912) described Centronycteris centralis as a distinct species, Sanborn (1937) concluded that it represented only the Central American subspecies of $C$. maximiliani. One subspecies, C. m. centralis, is found both in the Caribbean and Pacific wet tropical lowlands of Costa Rica, but there are few specimens on record.

Centronycteris maximiliani is uncommon throughout its range, and information on its natural history is almost nonexistent. The known distribution suggests 


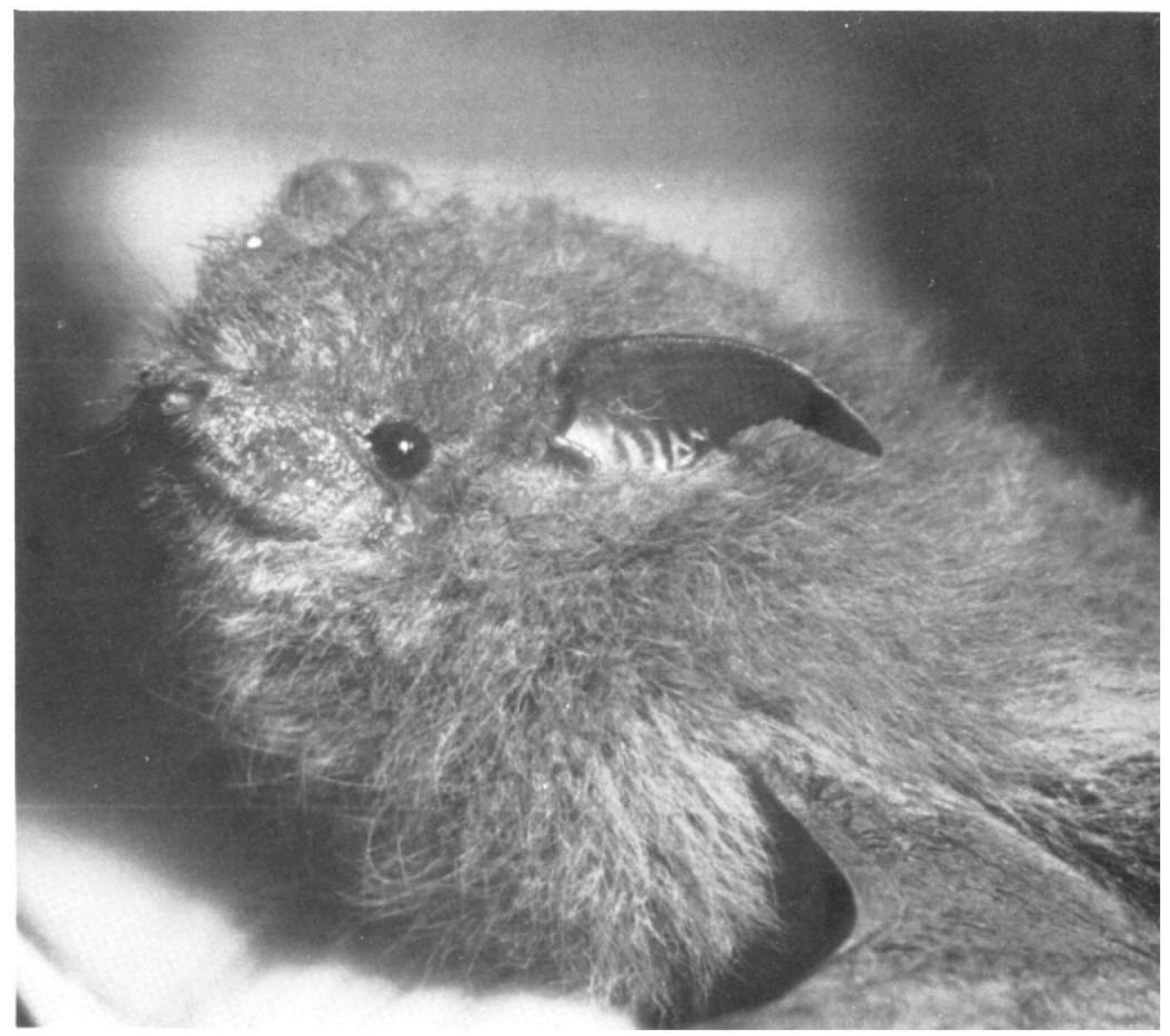

Fig. 10. Thomas' bat, Centronycteris maximiliani. Photo by R. K. LaVal.

that it is limited to lowland tropical rainforest. Both Goodwin (1946) and Albuja (1983) reported Ecuadoran specimens taken from tree holes. Although no data have been reported, $C$. maximiliani is almost surely insectivorous (Wilson 1973a). LaVal (1977) found pregnant females in May and subadults in September at La Selva, suggesting the monestrous pattern common to other emballonurids (Wilson 1973b).

The first Costa Rican specimen of $C$. maximiliani came from La Bijagua, on the Caribbean slope of Volcán Miravalles in Alajuela Province (Allen and Barbour 1923). Additional specimens were collected on the Osa Peninsula (Gardner et al. 1970; Starrett and Casebeer 1968). LaVal (1977) captured four individuals at La Selva in 1973. LaVal also observed a single individual roosting $12 \mathrm{~m}$ up on a tree trunk at Carrara Biological Reserve, in tropical moist forest on the Pacific slope.

Specimen examined (1)-Finca La Selva, $3 \mathrm{~km} \mathrm{~S}$ of Puerto Viejo, $70 \mathrm{~m}$ [1 female, KU]. 


\section{Cormura brevirostris \\ Wagner's Sac-winged Bat}

Wagner's sac-winged bats are found from Nicaragua south through Central America to the Amazon basin in South America (Fig. 11). This monotypic species is the only member of the genus.

The biology of this uncommon emballonurid is poorly known. It is known to roost in hollow trees in South America (Sanborn 1941; Tuttle 1970). Fleming et al. (1972) reported insects from the stomachs of Panamanian Cormura. They also reported pregnant females only in April and May, suggesting a monestrous reproductive cycle.

Although rare at La Selva, we caught individuals occasionally in the second growth of the successional plots. Our only specimen from Parque Nacional Braulio Carrillo was taken in a mist net over the Río Cantarrana near the $300-\mathrm{m}$ base camp. It is the only specimen record of this species for northern and eastern Costa Rica.

Specimen examined (1)-11 km S, $4.5 \mathrm{~km} \mathrm{~W}$ of Puerto Viejo, $270 \mathrm{~m} \mathrm{[1} \mathrm{male,}$ USNM].

\section{Cyttarops alecto \\ Short-eared Bat}

The short-eared bat is known only from eastern Nicaragua, Costa Rica, Guyana, and Amazonian Brazil. The genus contains only this monotypic species. All specimens of Cyttarops alecto have come from tropical lowland rain forest. Natural history information on this rare species is limited to that provided by Starrett (1972). All Costa Rican specimens have been taken from roosts under palm leaves. This species is presumably insectivorous, like other emballonurids. Nothing is known of the reproductive cycle.

This rare species was known only by the type specimen from Brazil and a single specimen from Guyana (Thomas 1913) until 1964 when three individuals were reported from Los Diamantes, about $25 \mathrm{~km}$ east of Parque Nacional Braulio Carrillo (Starrett and de la Torre 1964). Starrett and Casebeer (1968) reported eight specimens from Puerto Viejo, $3 \mathrm{~km}$ north of La Selva. We did not encounter this species at higher elevations.

Specimens examined (5)-Puerto Viejo de Sarapiquí [1 male, 4 females, LACM].

\section{Peropteryx kappleri Greater Doglike Bat}

Greater doglike bats are found from Veracruz, Mexico, south throughout Central America and much of tropical South America to southern Brazil (Fig. 12). The nominate subspecies, Peropteryx kappleri kappleri, is found throughout the range except for the type locality of the other named subspecies $(P . k$. intermedia) in Peru.

Individuals have been taken from sea level up to $1,500 \mathrm{~m}$ and in a variety of habitats. They roost singly or in small groups of mixed sex in shallow caves, 


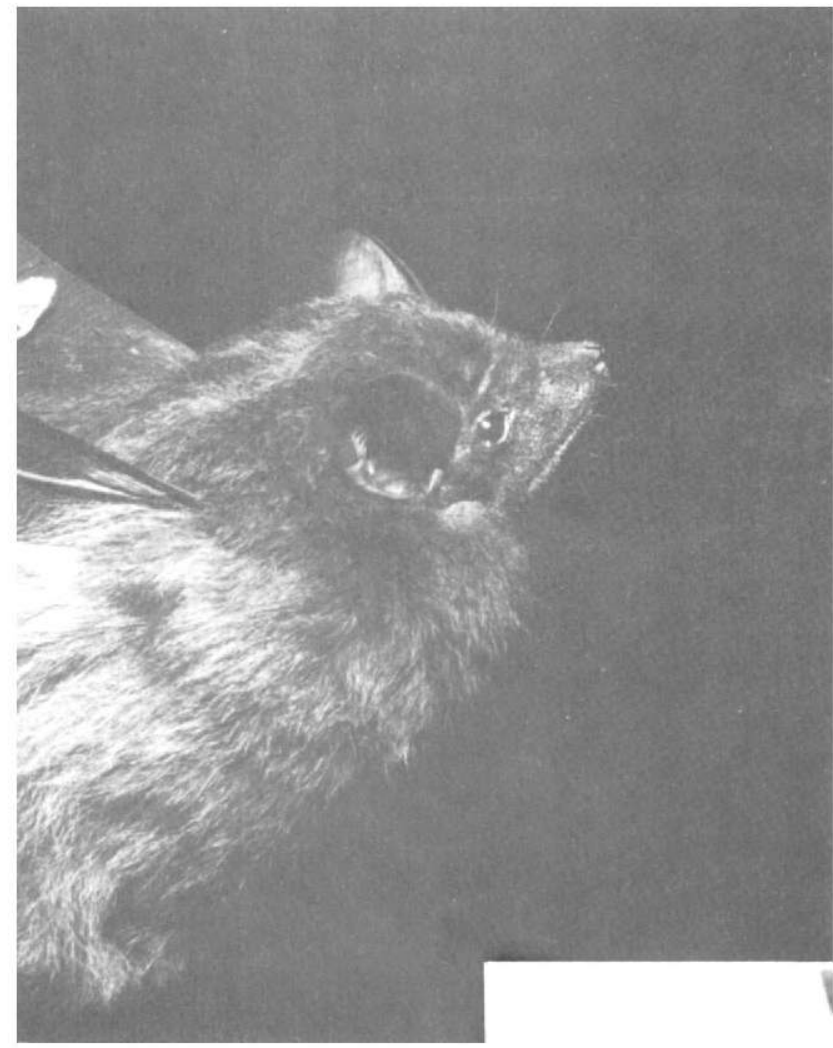

Fig. 11. Wagner's sacwinged bat, Cormura brevirostris. Photo by B. L. Clauson.

Fig. 12. Greater doglike bat, Peropteryx kappleri. Photo by $R$. K. LaVal.

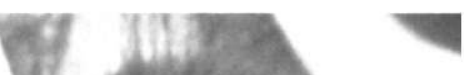


rock crevices, and hollow trees (Bradbury and Vehrencamp 1976). This species is insectivorous. The breeding cycle is monestrous and highly synchronous (Rasweiler 1982).

LaVal (1977) frequently found these bats roosting on the undersides of fallen logs, which were supported above ground by buttresses. In several cases they were roosting stacked atop one another, as many as four deep. They are rarely captured in mist nests. We did not encounter this species in Parque Nacional Braulio Carrillo.

Specimen examined (1)-Finca La Selva, $3 \mathrm{~km} \mathrm{~S}$ of Puerto Viejo, $70 \mathrm{~m} \mathrm{[1}$ male, MSB].

\section{Rhynchonycteris naso Brazilian Long-nosed Bat}

Brazilian long-nosed bats are found from Oaxaca and Veracruz, Mexico, through Central America to central Brazil (Fig. 13). The genus contains only this monotypic species.

This is a lowland species commonly found along watercourses in both wet and dry tropical forests. Individuals roost in open situations, frequently on the undersides of tree trunks or logs extending out over watercourses. The species is insectivorous. Reproduction may be asynchronous or aseasonal and individual females may produce more than one young per year (Bradbury and Vehrencamp 1977).

Originally reported from Costa Rica on the basis of 10 specimens collected by G. K. Cherrie from an unknown locality (Allen 1897), this species first was reported from La Selva by Starrett and Casebeer (1968). An adult female with a near-term fetus $22 \mathrm{~mm}$ long was taken at La Selva on 18 July 1974. During the early 1980's, a colony of Rhynchonycteris naso was observed on numerous occasions roosting under the eaves of the old field station building. A group also roosted under the cement steps leading to the boat dock. In late July and early August of 1983 , the colony contained 16 individuals; 2 of the females were suckling young.

Specimens examined (7)-Finca La Selva, $3 \mathrm{~km} \mathrm{~S}$ of Puerto Viejo, $70 \mathrm{~m}$ [3 males, 2 females, MSB]; $4 \mathrm{mi} \mathrm{W}$ of Puerto Viejo de Sarapiquí, $92 \mathrm{~m}$ [1 male, TCWC]; $7.2 \mathrm{~km} \mathrm{~W}$ of Puerto Viejo, $100 \mathrm{~m}$ [1 male, KU].

\section{Saccopteryx bilineata \\ Greater White-lined Bat}

The greater white-lined bat is widespread from Colima, Mexico, to Brazil (Fig. 14). The two subspecies recognized by Alvarez (1968) are Saccopteryx bilineata centralis from Nicaragua northward, and the nominate race, $S . b$. bilineata, throughout Costa Rica and southward.

This insectivorous species occurs in a variety of habitats, generally limited to lowlands. Bradbury and Vehrencamp (1976) and Bradbury (1983a) provided considerable natural history information on S. bilineata in Costa Rica and at La Selva in particular. Roosting sites include inside hollow trees, between buttresses of large trees, and, occasionally, the sides of manmade structures. Reproduction is seasonally synchronized, and females are monestrous. 


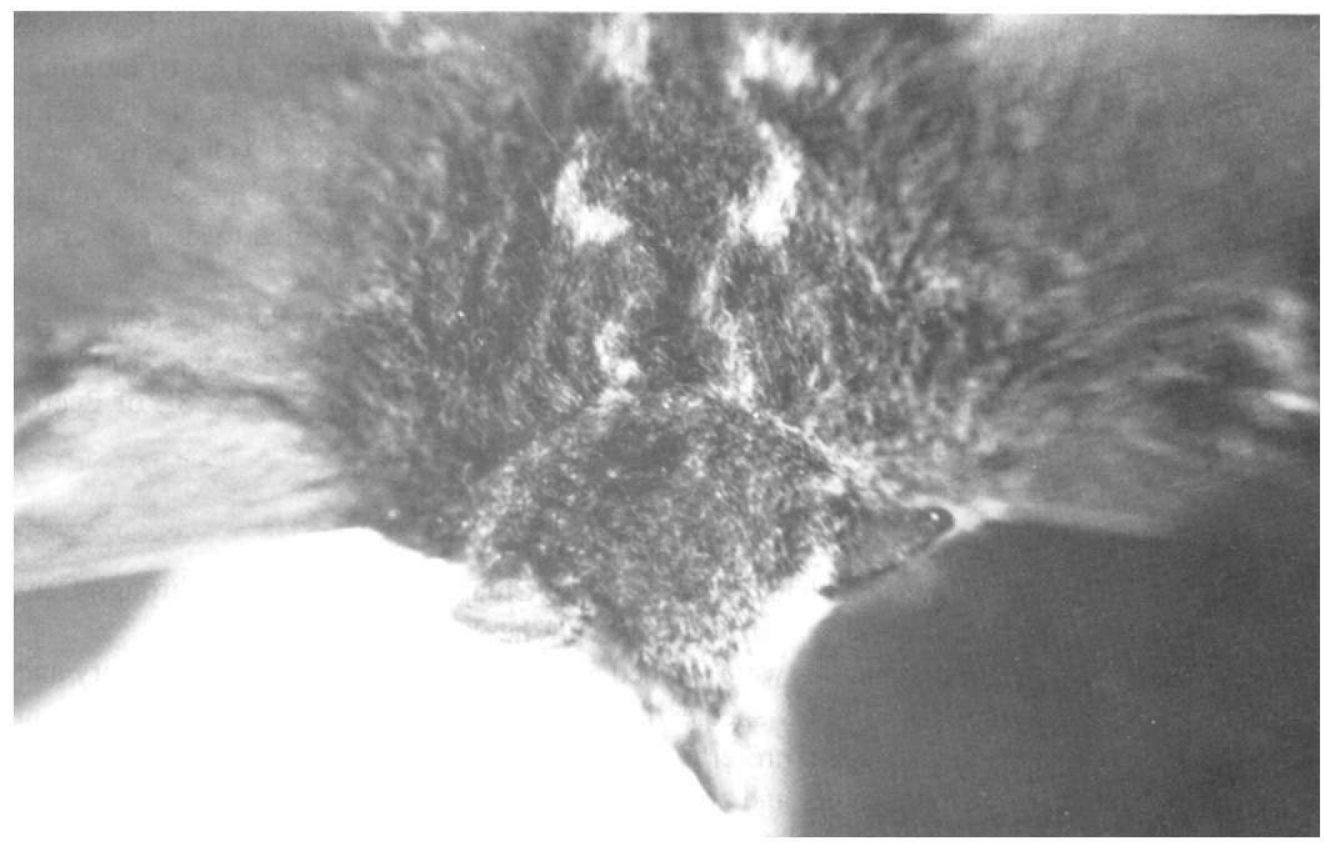

Fig. 13. Brazilian long-nosed bat, Rhynchonycteris naso. Photo by D. E. Wilson.

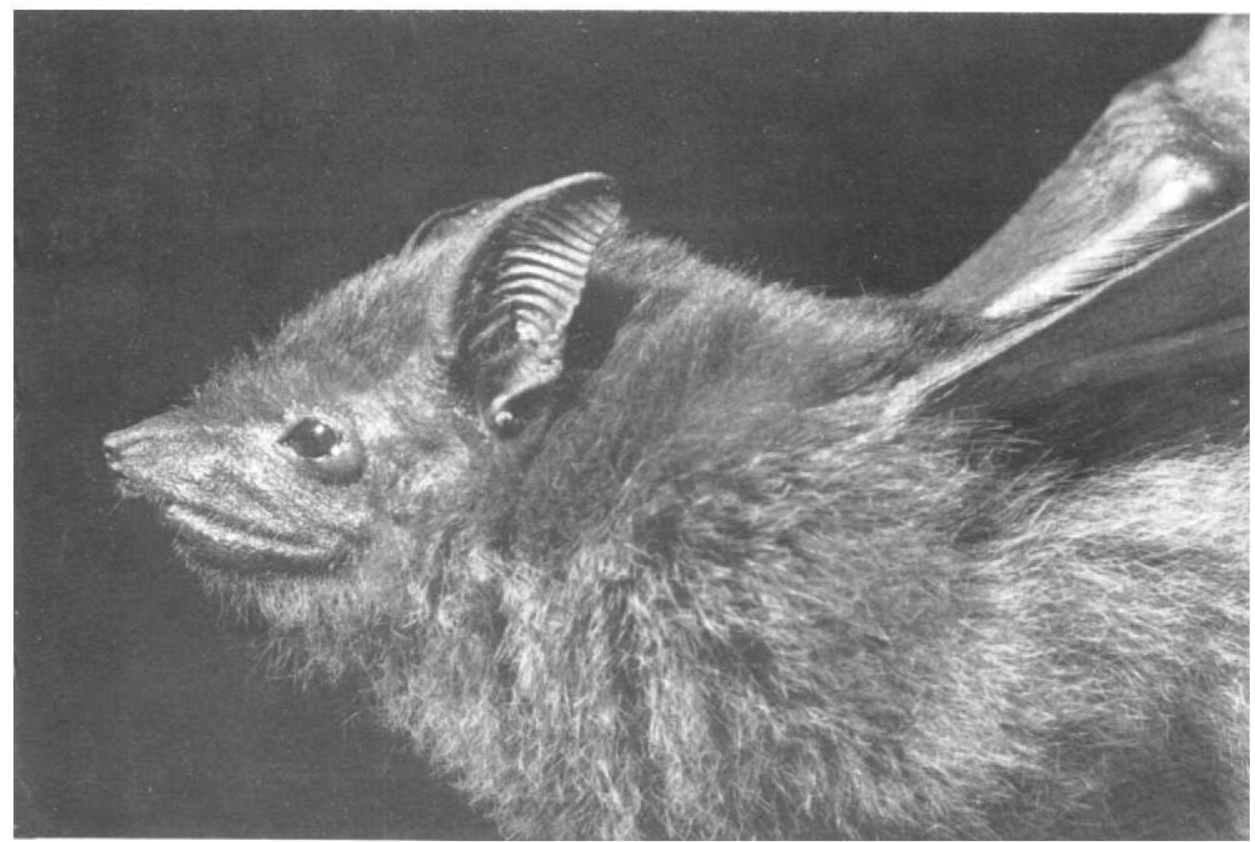

Fig. 14. Greater white-lined bat, Saccopteryx bilineata. Photo by B. L. Clauson. 
Abundant throughout lowland Costa Rica, S. bilineata occurs at La Selva both in large colonies in hollow trees, and in smaller groups on the sides of buildings and in buttresses of large forest trees. On 1 August 1983 at La Selva, three harems of Saccopteryx were located by A. Alberts in a large "Ceiba." One harem contained eight females, three with young; one contained five females, three with young; and one contained four females, one with young. Males seemed to spend most of their time at the territorial boundaries (A. Alberts, in litt.).

Specimens examined (13)-Finca La Selva, $3 \mathrm{~km} \mathrm{~S}$ of Puerto Viejo, $70 \mathrm{~m}$ [1 male, KU; 1 male, 1 female, LACM; 5 females, MSB]; Puerto Viejo, Río Sarapiquí, $100 \mathrm{~m}$ [1 male, 1 female, KU; 2 females, UMMZ]; $2.5 \mathrm{~km}$ SE of Puerto Viejo [1 female, TCWC].

\section{Saccopteryx leptura \\ Lesser White-lined Bat}

Lesser white-lined bats are found from Chiapas, Mexico, south through Central America to eastern Brazil (Fig. 15). The species is monotypic.

Population dynamics were studied extensively in Costa Rica by Bradbury and Vehrencamp (1976). This species is less common than Saccopteryx bilineata in most areas, and seems to prefer more open roosting sites. Group size is also much smaller, but food habits and reproductive patterns seem similar.

Although previously known from Panama and Nicaragua, this species was first reported from Costa Rica by Starrett and Casebeer (1968). LaVal and Fitch (1977) reported seven individuals from La Selva. We did not encounter this species in Parque Nacional Braulio Carrillo.

Specimen examined (1)-Puerto Viejo, Río Sarapiquí, 300 ft [1 female, UMMZ].

\section{Family Noctilionidae \\ Noctilio albiventris \\ Lesser Bulldog Bat}

Lesser bulldog bats are found from Chiapas, Mexico, to Argentina (Fig. 16). The Costa Rican subspecies, Noctilio albiventris minor, is found throughout Central America to northern South America.

Primarily an inhabitant of wet tropical forests, this species forages for insects mainly over rivers, streams, and wetlands. Although roosts are known from hollow trees and caves, large colonies frequently are found in buildings. The reproductive cycle appears to be one of seasonal monestry (Hood and Pitocchelli 1983).

Apparently the first published record of $N$. albiventris from Costa Rica was that of Davis et al. (1964), who reported a single female from La Selva. LaVal and Fitch (1977) also reported capturing only a single individual, a pregnant female, in August. These bats, however, are common in the area and can be seen foraging over the Río Puerto Viejo, where we have netted them on several occasions, the most recent of which was in January 1987.

Specimen examined (1)-Puerto Viejo, Río Sarapiquí, 300 ft [1 male, UMMZ]. Additional record (1) $-4 \mathrm{mi} \mathrm{W}$ of Puerto Viejo, $300 \mathrm{ft}$ [1 female, TCWC]. 


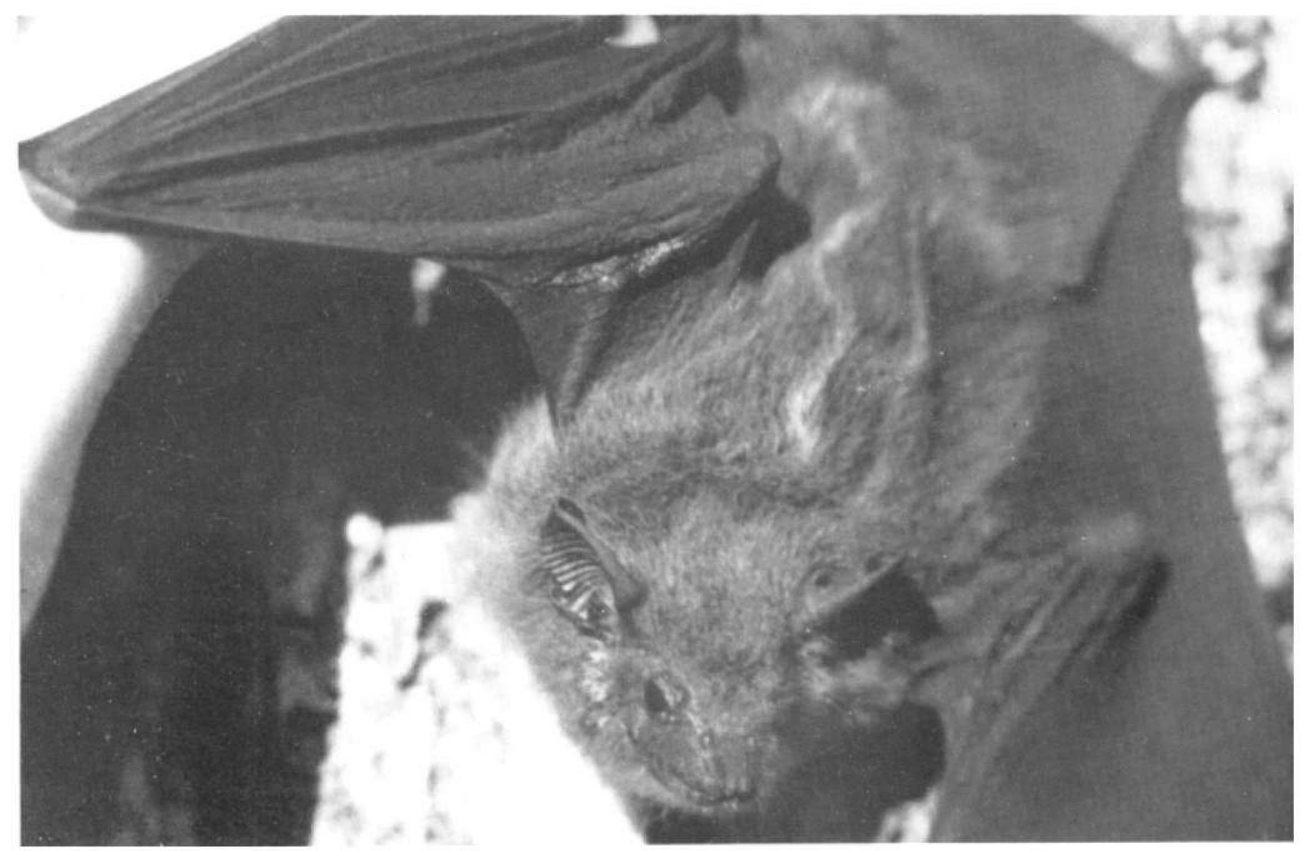

Fig. 15. Lesser white-lined bat, Saccopteryx leptura. Photo by R. K. LaVal.

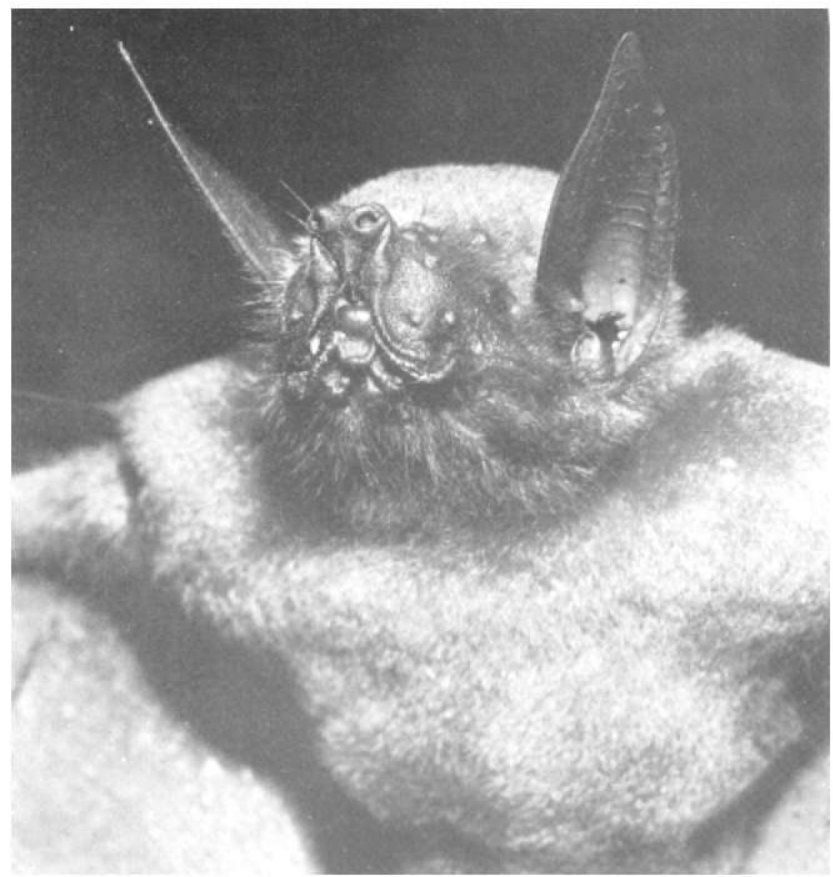

Fig. 16. Lesser bulldog bat, Noctilio albiventris. Photo by $B$. L. Clauson. 


\section{Noctilio leporinus \\ Greater Bulldog Bat}

Greater bulldog bats are known from Sinaloa and Veracruz, Mexico, to Argentina (Fig. 17). The Costa Rican subspecies, Noctilio leporinus mastivus, is found throughout Central America and northern South America.

Although known from both dry and wet tropical forests, this species is found mainly along major lowland river systems. Roosts are known from hollow trees and sea caves (Hood and Jones 1984), and Mares et al. (1981) reported a night roost under a bridge occupied by several hundred individuals. These bats feed on insects and on fish, which they gaff at the surface of the water with their long claws (Brandon 1983).

The first record for Costa Rica was that of Carter et al. (1966). Although no specimens have been preserved from La Selva, these large bats can be seen foraging low over the Río Puerto Viejo. A group roosted under the cement steps leading to the boat dock in the late 1970's and early 1980's, but they have not used this site in recent years.

Specimens examined (2)-7.3 mi SE of Puerto Viejo [2 males, TTU].

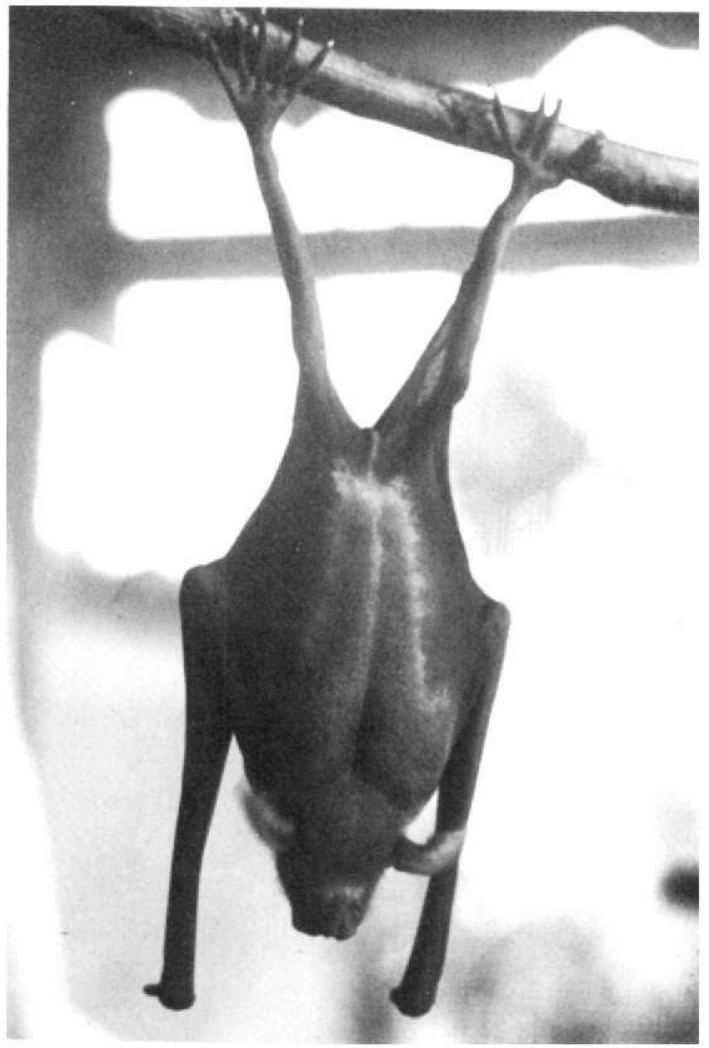

Fig. 17. Greater bulldog bat, Noctilio leporinus. Photo by R. K. LaVal. 


\section{Family Mormoopidae}

\section{Pteronotus davyi Davy's Naked-backed Bat}

Davy's naked-backed bats are found from central Sonora and southern Tamaulipas, Mexico, through Central America to northern South America (Fig. 18). The distribution of Pteronotus davyi in southern Central America and northern South America is poorly understood; this species is represented from Costa Rica, Venezuela, and eastern Peru by only a few specimens. There are apparently no records of Davy's naked-backed bat from Panama, Colombia, or Ecuador. In a recent revision of the family, Smith (1979) recognized three subspecies of $P$. davyi, and considered the nominate race $P$. $d$. davyi to be the subspecies found in Costa Rica. The biology and distribution of this species recently was reviewed by Adams (1989).

Starrett and Casebeer (1968) reported the first specimens of Davy's nakedbacked bats from Costa Rica. They obtained a total of four specimens from three localities in northwestern Costa Rica; one of the localities was in Alajuela Province and two were in Guanacaste Province. On the basis of this report, Wilson (1983) listed the species as present at Palo Verde. There have been no other reports of this diminutive naked-backed bat from the country.

On 28 July 1983, J. Wenzel captured a single adult female in a mist net set in the arboretum clearing at La Selva. This is the first record of this species from the Caribbean lowlands of Costa Rica.

Specimen examined (1)-Finca La Selva, $3 \mathrm{~km} \mathrm{~S}$ of Puerto Viejo, $70 \mathrm{~m}$ [1 female, KU].

Fig. 18. Davy's nakedbacked bat, Pteronotus davyi. Photo by $R$. K. LaVal.

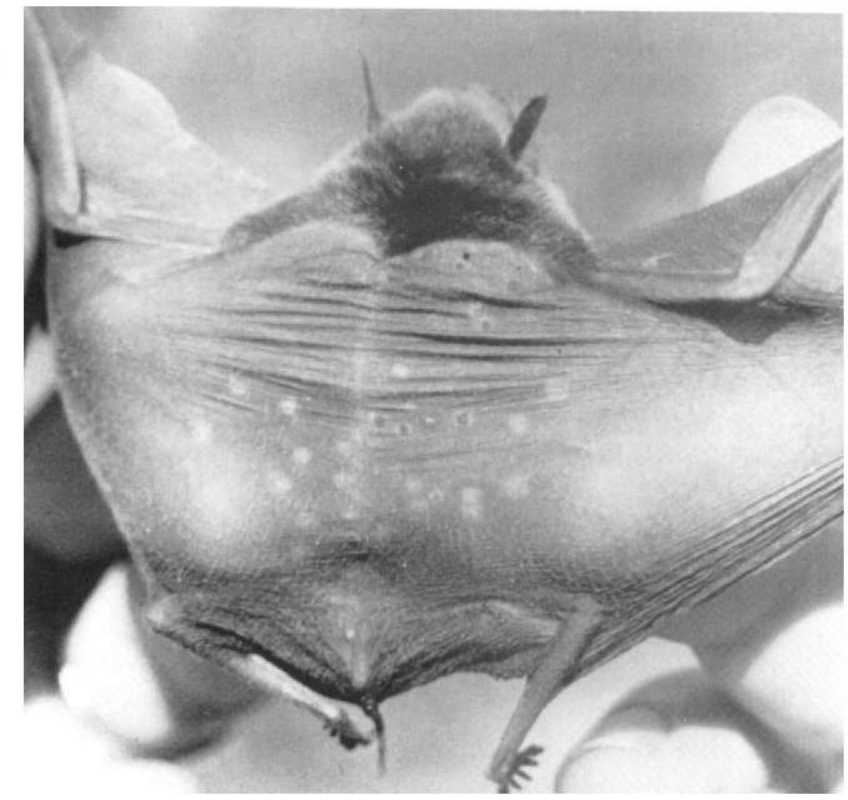




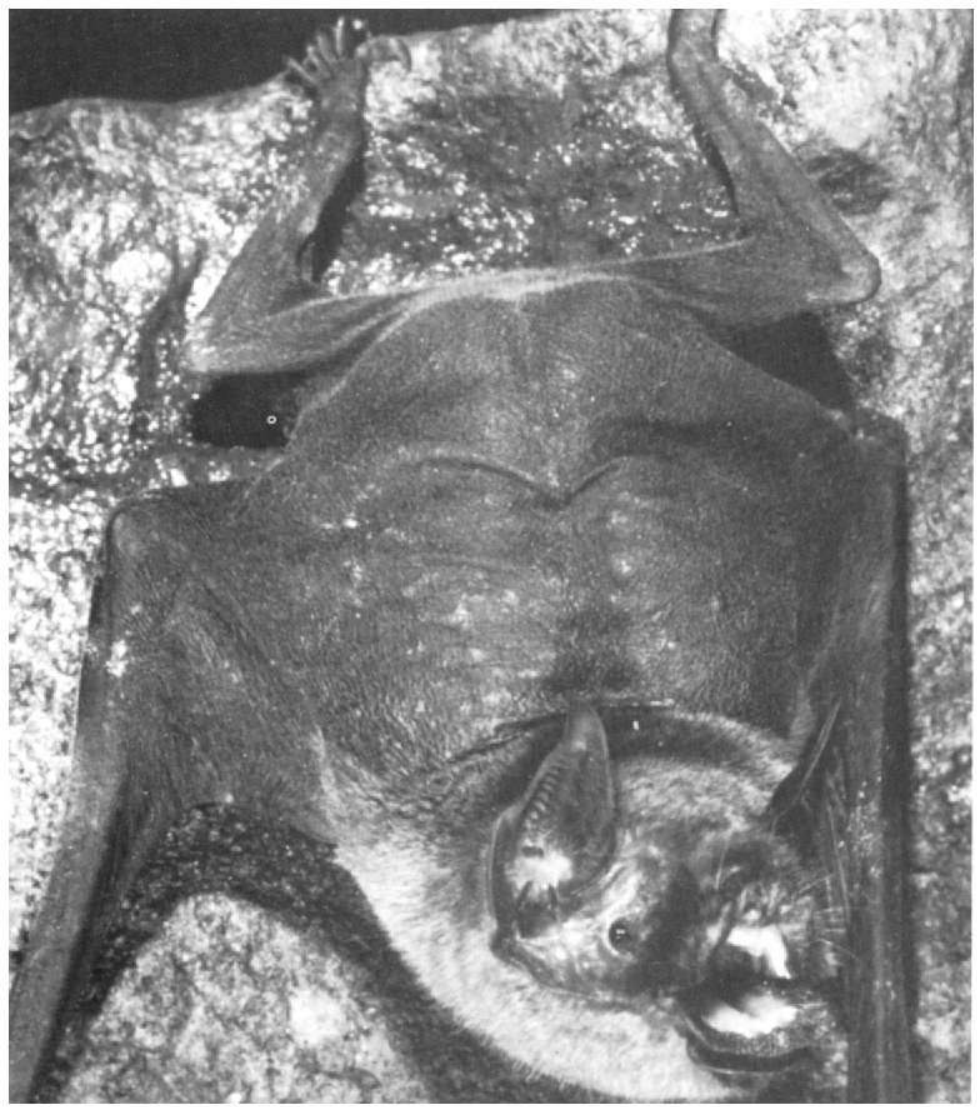

Fig. 19. Big nakedbacked bat, Pteronotus gymnonotus. Photo by $R$. $K$. LaVal.

\section{Pteronotus gymnonotus Big Naked-backed Bat}

Big naked-backed bats are widely distributed from Veracruz, Mexico, to southwestern Brazil (Fig. 19). The species is monotypic.

Although known from a variety of habitats, this species is primarily an inhabitant of lowland forests. Roosts are usually in caves, and colonies may be quite large. Pteronotus gymnonotus is an aerial insectivore. Reproduction has not been studied, but other members of the family are monestrous (Wilson 1973b).

The first Costa Rican record of this species was from Boruca (Sanborn 1932). Starrett and Casebeer (1968) shot individuals foraging above roadways in two localities in southern Costa Rica. Our specimen is the first record for the La Selva region. It was taken in a mist net set over the Río Cascante in an area where the forest had been cleared for pasture.

Specimen examined (1)-1 km S, $11.5 \mathrm{~km}$ E of San Miguel, $680 \mathrm{~m}$ [1 female, USNM]. 
Fig. 20. Parnell's mustached bat, Pteronotus parnellii. Photo by B. L. Clauson.

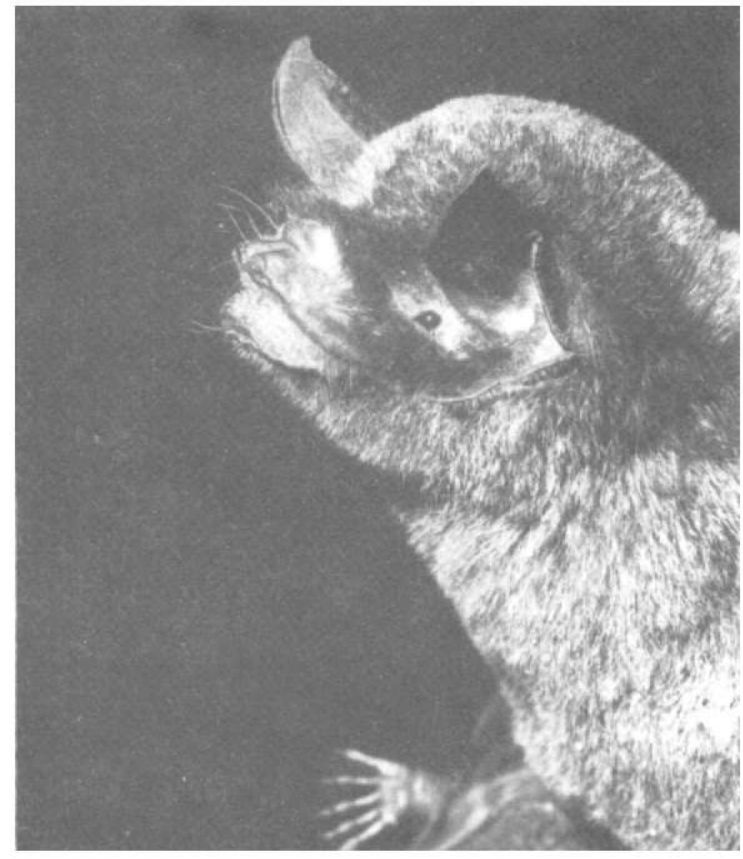

\section{Pteronotus parnellii \\ Parnell's Mustached Bat}

Parnell's mustached bats are found from Sonora, Mexico, to Brazil (Fig. 20). This species is known from a broad range of habitats from sea level up to $3,000 \mathrm{~m}$ (Smith 1972). Two subspecies are known from Costa Rica: Pteronotus parnellii mesoamericanus from the Pacific side and $P$. p rubiginosus from the Caribbean versant. Large colonies roost in caves and in mines (Herd 1983). Insects, which are the main food source, are captured on the wing. The reproductive pattern is one of seasonal monestry (Wilson 1973b).

Parnell's mustached bats are common throughout Costa Rica, and can be captured in mist nets set almost anywhere in the forest. They were netted regularly over the years in the primary forest at La Selva, although never in large numbers, and we found them to be common at lower elevations in Parque Nacional Braulio Carrillo. LaVal and Fitch (1977) captured 25 at La Selva; pregnant females were found from January through May.

Ectoparasites collected from Pteronotus parnellii include the bat flies Nycterophilia parnelli ( 5 males, 1 female), Trichobius sparsus (10 males, 6 females), and Trichobius yunkeri (15 males, 8 females).

Specimens examined (20)-Finca La Selva, $3 \mathrm{~km} \mathrm{~S}$ of Puerto Viejo, $70 \mathrm{~m}$ [1 female, KU; 1 male, 1 female, MSB]; $11 \mathrm{~km} \mathrm{S,} 4.5 \mathrm{~km}$ W of Puerto Viejo, $270 \mathrm{~m}$ [3 females, USNM; 1 female, UNA]; $1 \mathrm{~km} \mathrm{S,} 11.5 \mathrm{~km}$ E of San Miguel, $680 \mathrm{~m}$ [10 males, 1 female, USNM; 1 male, 1 female, UNA], 


\section{Family Phyllostomidae \\ Subfamily Phyllostominae \\ Chrotopterus auritus \\ Peter's False Vampire Bat}

Peter's false vampire bats are found from the southern Mexican States of Oaxaca and Veracruz through Central America to the Guianas, across northern and southern Brazil, eastern Peru, and southeast to northern Argentina (Fig. 21). Although Chrotopterus auritus is widely distributed, there are few actual specimens of this species and we know little of its distribution and biology. Chrotopterus auritus probably is best considered as a monotypic species.

The diet of these large phyllostomines consists of small vertebrates and large insects. Medellín (1988) found that $86 \%$ of prey items from a roost in Mexico were vertebrates, and that $79 \%$ of those were rodents and shrews. Roost sites include hollow trees (Medellín 1988) and caves (Graham 1988). Wilson (1979) summarized what little information is available on reproduction in this species, and suggested that it is likely the young are born during the early part of the rainy season.

Little is known concerning the status of Peter's false vampire in Costa Rica. Goodwin (1946) listed C. auritus as a species occurring in Costa Rica; however, he did not cite either specimens from the country or localities, so it seems that he had no actual records available but included it because of suspected distribution. Starrett and Casebeer (1968) were the first to report specimens of $C$. auritus from Costa Rica. They obtained a total of seven males and one female from a single hollow $\log$ at Finca La Lola in Limón Province at $50 \mathrm{~m}$ elevation in July 1961 and September 1962. Wilson (1983) listed Peter's false vampire bat from Guanacaste Province.

On 8 May 1988, A. P. Brooke captured a single young adult female $C$. auritus at La Selva. The bat was mist-netted in primary forest at $1645 \mathrm{~h}$; it was followed by radiotelemetry and released (A. P. Brooke, in litt.). This is the first record of Peter's false vampire bat from La Selva. Brooke (1988) found this female to direct foraging attacks only at birds and bats when they flew by, ignoring insects. She suggested that $C$. auritus has a "sit-and-wait" foraging strategy, hunting only selected, active prey.

\section{Lonchorhina aurita \\ Tomes' Long-eared Bat}

Tomes' long-eared bat is found from Oaxaca, Mexico, to Brazil (Fig. 22). Although Anthony (1923) named Lonchorhina occidentalis as a distinct species, recent workers have placed it in synonymy with $L$. aurita, which is considered monotypic (Lassieur and Wilson 1989).

Although mainly a bat of the primary forest, it has been taken in agricultural areas as well (Handley 1976). The most common roosting sites are caves or tunnels. Although this species is insectivorous and probably a foliage gleaner. Fleming et al. (1972) reported a single individual with fruit pulp in its stomach. The scant evidence available suggests a reproductive cycle tied to the rainy season. 


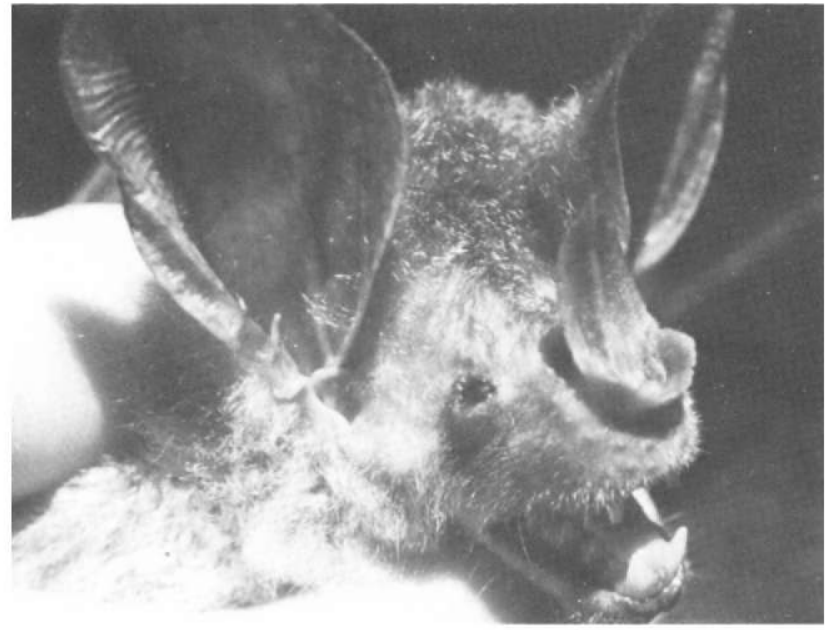

Fig. 21. Peter's false vampire bat, Chrotopterus auritus. Photo by $R$. K. LaVal.

Fig. 22. Tomes' long-eared bat, Lonchorhina aurita. Photo by B. L. Clauson.

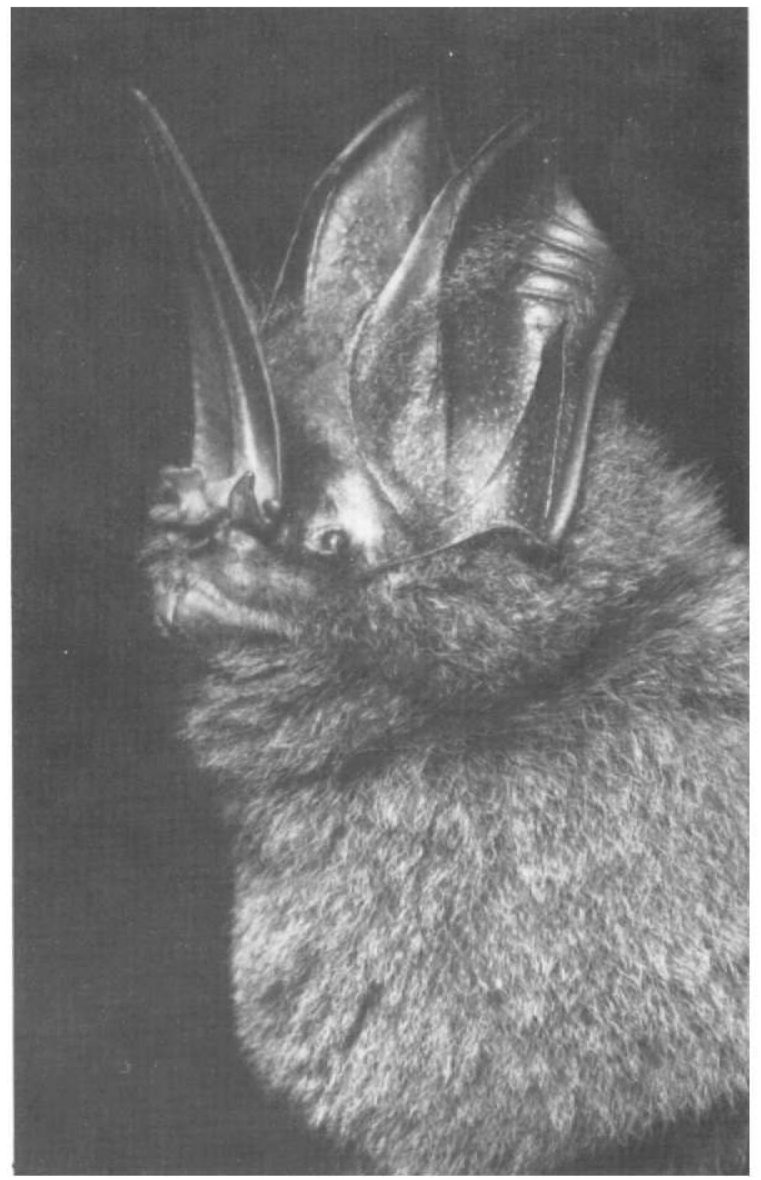


The first record of this species for Costa Rica is that of Nelson (1965), who collected 13 from a cave near Moravia de Turrialba in Cartago Province. This species has not been collected at La Selva. Our specimens from Parque Nacional Braulio Carrillo were mist-netted in primary forest. Lonchorhina aurita appears at mid-elevations in Braulio Carrillo, but is found at lower elevations elsewhere in its range.

Parasites collected from $L$. aurita include the bat flies Speiseria ambigua (1 male) and Trichobius flagellatus (12 males, 7 females).

Specimens examined (8)-11 km S, $4.5 \mathrm{~km} \mathrm{~W}$ of Puerto Vicjo, $270 \mathrm{~m} \mathrm{[3}$ males, USNM]; $1 \mathrm{~km} \mathrm{S,} 11.5 \mathrm{~km} \mathrm{E}$ of San Miguel, $680 \mathrm{~m}$ [4 males, USNM; 1 male, UNA].

\section{Macrophyllum macrophylum Long-legged Bat}

Long-legged bats occur from Chiapas and Tabasco, Mexico, through Central America and South America to Argentina (Fig. 23). Macrophyllum macrophyllum is monotypic.

This species normally is captured over streams in forested habitats (Tuttle 1970). It is known to roost in caves and road culverts (Greenhall and Paradiso 1968) but probably also uses hollow trees. Gardner (1977) reported water striders (Gerridae) in the diet, and suggested that Macrophyllum might be the only completely insectivorous member of the subfamily Phyllostcminae. LaVal's (1977) data suggest that young are born in June or July, but little is known of the overall reproductive cycle (Wilson 1979). The biology of this species was summarized by Harrison (1975).

The species first was reported from Costa Rica by Starrett and Casebeer (1968) from Guanacaste and Limón Provinces. LaVal and Fitch (1977) reported capturing three at La Selva. One species of bat fly, Trichobius macrophylli (7 males, 2 females), was obtained on these long-legged bats at La Selva.

Specimens examined (2)-Finca La Selva, $3 \mathrm{~km} \mathrm{~S}$ of Puerto Viejo [1 male, MSB]; $7.3 \mathrm{mi}$ SE of Puerto Viejo [1 female, TTU].

\section{Micronycteris brachyotis \\ Dobson's Large-eared Bat}

Dobson's large-eared bat, a monotypic species, is found from Oaxaca and Veracruz, Mexico, to Amazonian Brazil. Although normally associated with forested habitats, this bat was reported roosting in savannahs by Husson (1978). Roost sites include caves, mines, and hollow trees (Medellín et al. 1985). Goodwin and Greenhall (1961) reported insects and fruit from stomachs of specimens from Trinidad. In Panama, Bonaccorso (1979) found evidence of a bimodal reproductive pattern.

The first Costa Rican specimens were taken by Fleming et al. (1972) in Guanacaste in 1970. LaVal and Fitch (1977) reported capturing three from La Selva. Apparently no specimens from the Caribbean lowlands have been preserved in collections. 


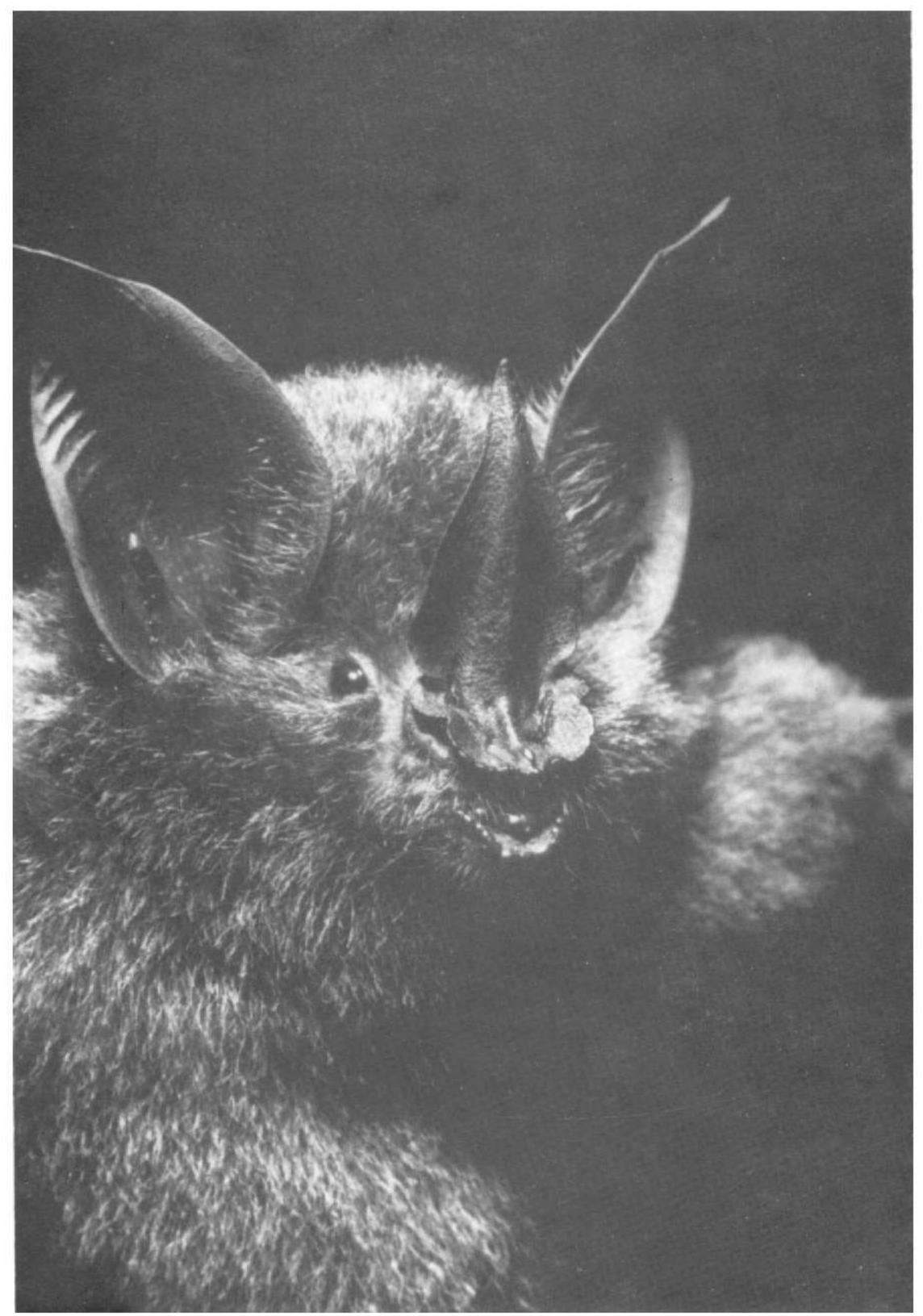

Fig. 23. Long-legged bat, Macrophyllum macrophyllum. Photo by B. L. Clauson. 


\section{Micronycteris daviesi \\ Davies' Large-eared Bat}

Davies' large-eared bats are known from scattered localities ranging from Honduras to Peru and Amazonian Brazil. This monotypic species is sometimes placed in the separate genus Barticonycteris.

Little is known about the natural history of Micronycteris daviesi. Specimens have been caught in mist nets in mature forest (Hill 1964). Tuttle (1970) reported three individuals in a hollow tree roost in Peru. No information is available on food habits or reproductive pattern.

This species is known from Costa Rica only by specimens collected at La Selva by us in the early 1970's (LaVal 1977), and by a single adult we netted and released there at $1930 \mathrm{~h}$ on 26 March 1986. A bat fly, Trichobius yunkeri (one fernale) was obtained from $M$. daviesi at La Selva.

Specimens examined (2)-Finca La Selva, $3 \mathrm{~km} \mathrm{~S}$ of Puerto Viejo, $70 \mathrm{~m}$ [1 male, KU; 1 male, MSB].

\section{Micronycteris hirsuta \\ Hairy Large-eared Bat}

Hairy large-eared bats occur from southern Honduras to Amazonian Brazil (Fig. 24). This monotypic species is most often collected in forested habitats, although Handley (1976) reported it in yards as well. These bats are known to roost in hollow trees, under bridges, in buildings, and in other manmade structures (Goodwin and Greenhall 1961). Wilson (1971) reported this species to be primarily insectivorous, but it consumes a variety of fruits during the dry season. There are some data suggesting the usual phyllostomid bimodal reproductive pattern (Wilson 1979).

Goodwin (1946) listed two specimens from Palmar and two specimens from Pozo Azul, and tentatively designated the latter as the type locality. Gardner et al. (1970) added a fifth specimen from Rincón de Osa on the Osa Peninsula. LaVal and Fitch (1977) reported four individuals from La Selva.

Specimens examined (3)-2.5 km SE of Puerto Viejo [1 male, CM]; Finca La Selva, $3 \mathrm{~km} \mathrm{~S}$ of Puerto Viejo [2 females, MSB].

\section{Micronycteris megalotis Brazilian Large-eared Bat}

Brazilian large-eared bats occur from Tamaulipas and Jalisco, Mexico, to southern Brazil (Fig. 25). In Costa Rica, two subspecies are recognized: Micronycteris megalotis mexicana from the Pacific side and $M . \mathrm{m}$. microtis from the Caribbean lowlands. This arrangement is based on few specimens (Gardner et al. 1970), and a study of geographic variation in this species would be useful.

This species uses a variety of habitats and occurs across a wide elevational range (Gardner et al. 1970). Many roosting sites, some of them unusual, have been reported for this species (Handley 1976): caves, mines, hollow trees, logs, stumps, buildings, bridges, wells, culverts, under roots, under rocks, and in large mam- 


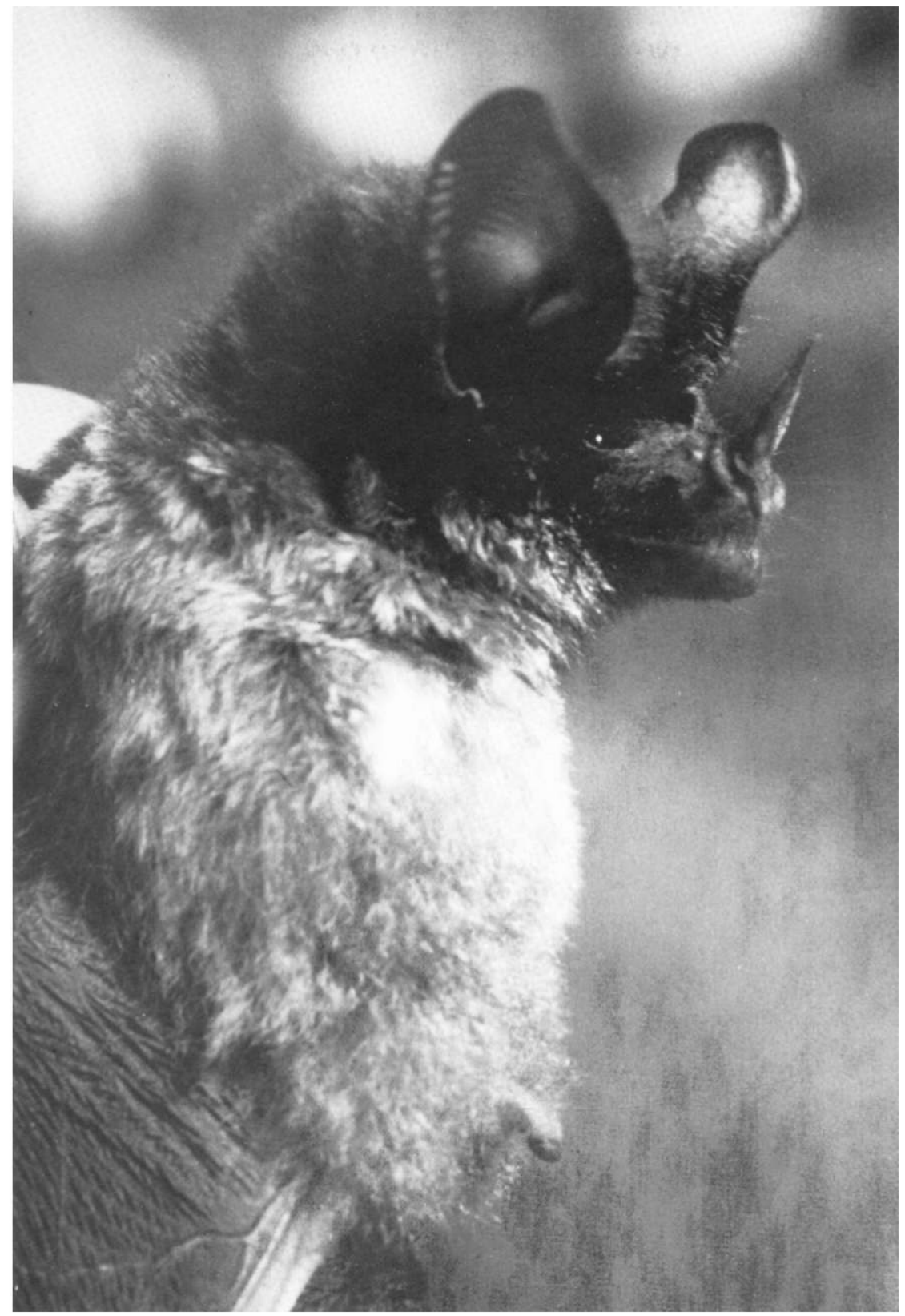

Fig. 24. Hairy large-eared bat, Micronycteris hirsuta. Photo by R. K. LaVal. 
mal burrows. It feeds on fruit and insects, as do most phyllostomines. LaVal and LaVal (1980) found remains of insects representing several orders at night-feeding roosts of these bats at La Selva. There is no complete study of the reproductive cycle from a single locality.

Goodwin (1946) reported M. m. microtis from Río Sixaola and Gardner et al. (1970) recorded the first M. m. mexicana from the country. LaVal and Fitch (1977)

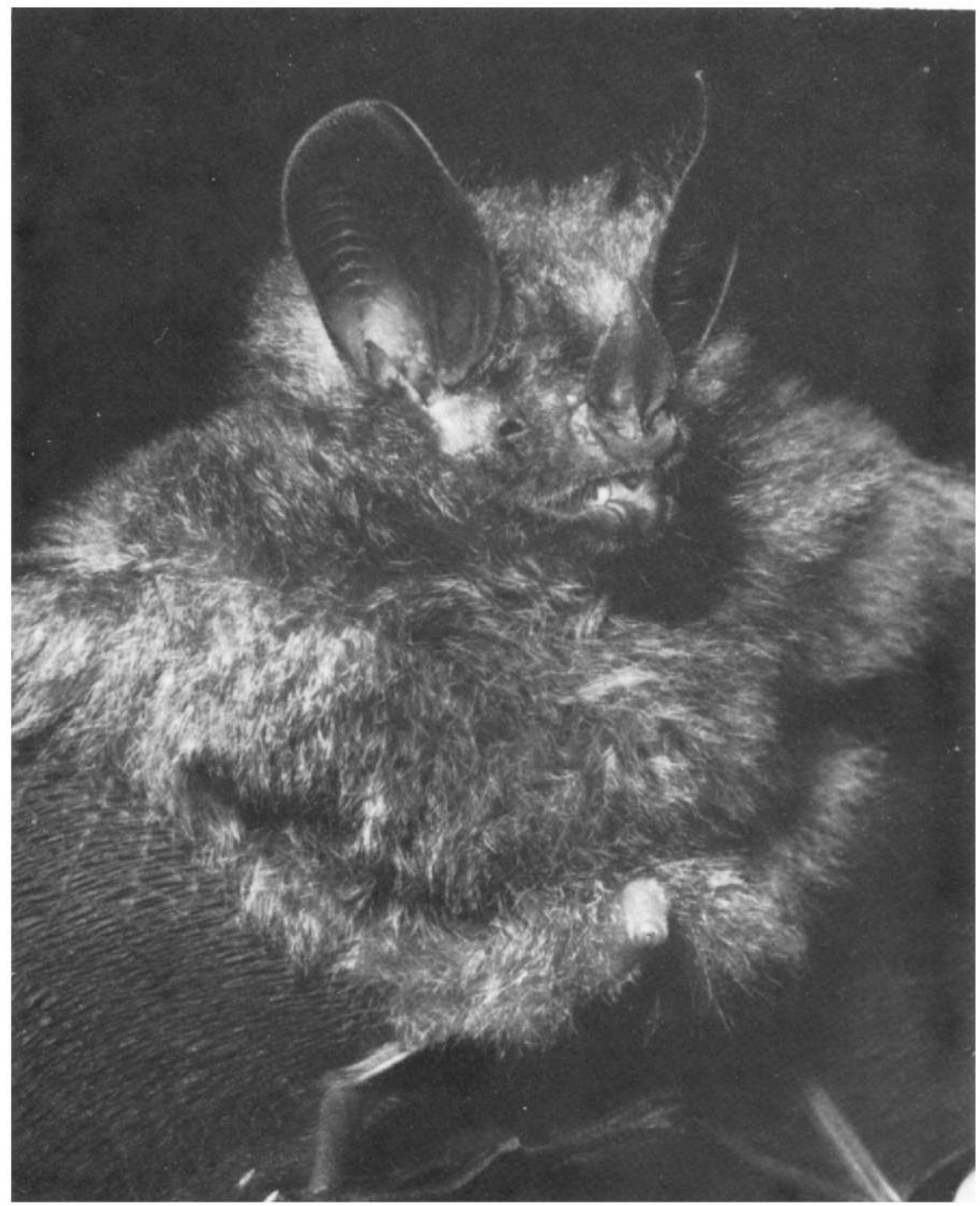

Fig. 25. Brazilian large-eared bat, Micronycteris megalotis. Photo by B. L. Clauson. 
captured 21 specimens at La Selva. One individual was netted over a small stream in primary forest.

Specimens examined (9)-Puerto Viejo, Río Sarapiquí, $300 \mathrm{ft}$ [2 males, 1 female, UMMZ]; Finca La Selva, $3 \mathrm{~km} \mathrm{~S}$ of Puerto Viejo, $70 \mathrm{~m}$ [1 male, KU; 1 male, LACM; 1 male, 1 female, MSB]; $5.7 \mathrm{mi} \mathrm{S}$ of Puerto Viejo [1 female, LACM]; $11 \mathrm{~km} \mathrm{S,} 4.5 \mathrm{~km}$ W of Puerto Viejo, $270 \mathrm{~m}$ [1 male, USNM].

\section{Micronycteris minuta}

\section{Gervais' Large-eared Bat}

Gervais' large-eared bat, a monotypic species, is known from Nicaragua to southern Brazil (Fig. 26). It is primarily an inhabitant of forested regions, but specimens also are known from agricultural areas (Williams and Genoways 1980). Roosts have been reported in hollow trees, caves, and mines (Sanborn 1949). These bats feed on insects and plant material (Fleming et al. 1972). Reproduction occurs at the beginning of the rainy season, but the complete cycle is unknown (Wilson 1979).

The first Costa Rican records were reported by Gardner et al. (1970) from Cartago, Guanacaste, and San José Provinces. LaVal and Fitch (1977) reported one from La Selva. We caught and released a second individual at La Selva in 1973. Apparently no individuals of Micronycteris minuta from La Selva have been preserved.

Fig. 26. Gervais' largeeared bat, Micronycteris minuta. Photo by $R$. K. LaVal.

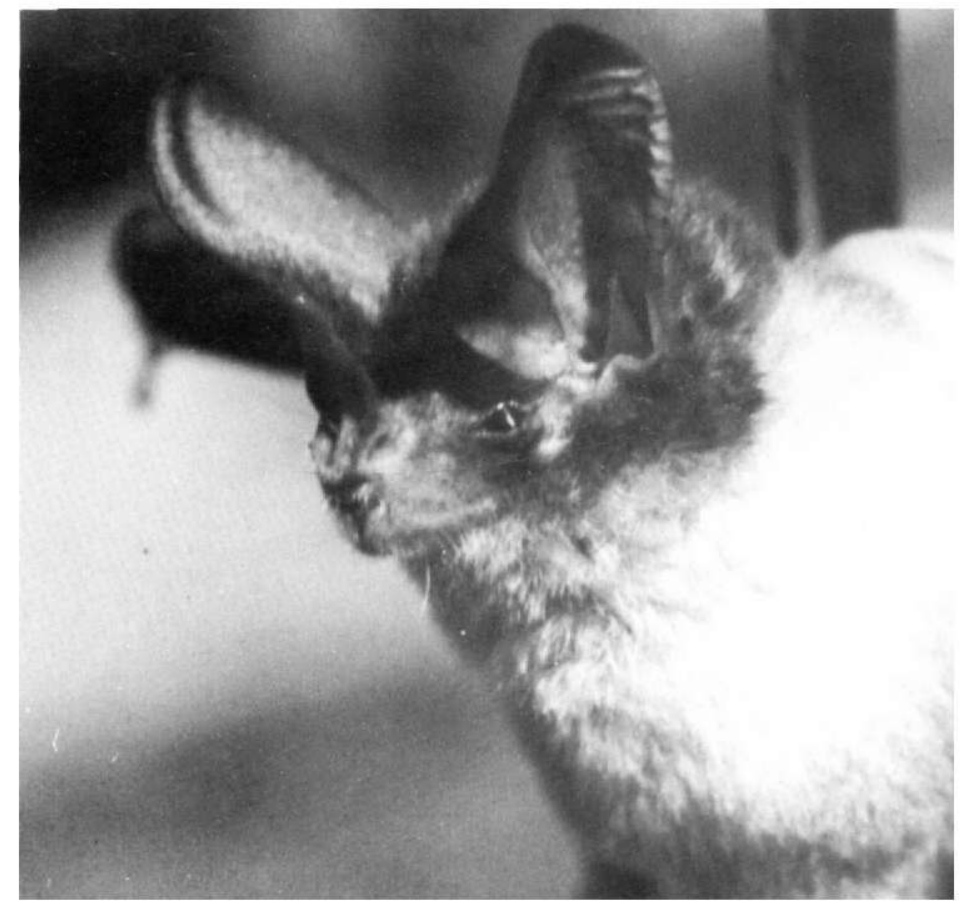


Fig. 27. Nicéforo's large-eared bat, Micronycteris nicefori. Photo by R. K. LaVal.

\section{Micronycteris nicefori \\ Nicéforo's Large-eared Bat}

These large-eared bats are found from Belize and southeastern Nicaragua along the Caribbean coast of Central America to Amazonian Brazil in South America (Fig. 27). The species is monotypic.

This species has been collected mainly from forested areas, but is also known from agricultural habitats (Williams and Genoways 1980). Roosting sites include hollow trees, mines, and buildings (Handley 1966). These bats feed on insects and fruit according to Goodwin and Greenhall (1961). The reproductive cycle is unknown.

LaVal (1977) reported capturing six at La Selva in 1973 and 1974; these were the first records from Costa Rica.

Specimen examined (1)-Finca La Selva, $3 \mathrm{~km} \mathrm{~S}$ of Puerto Viejo, $70 \mathrm{~m}$ [1 male, KU]. 


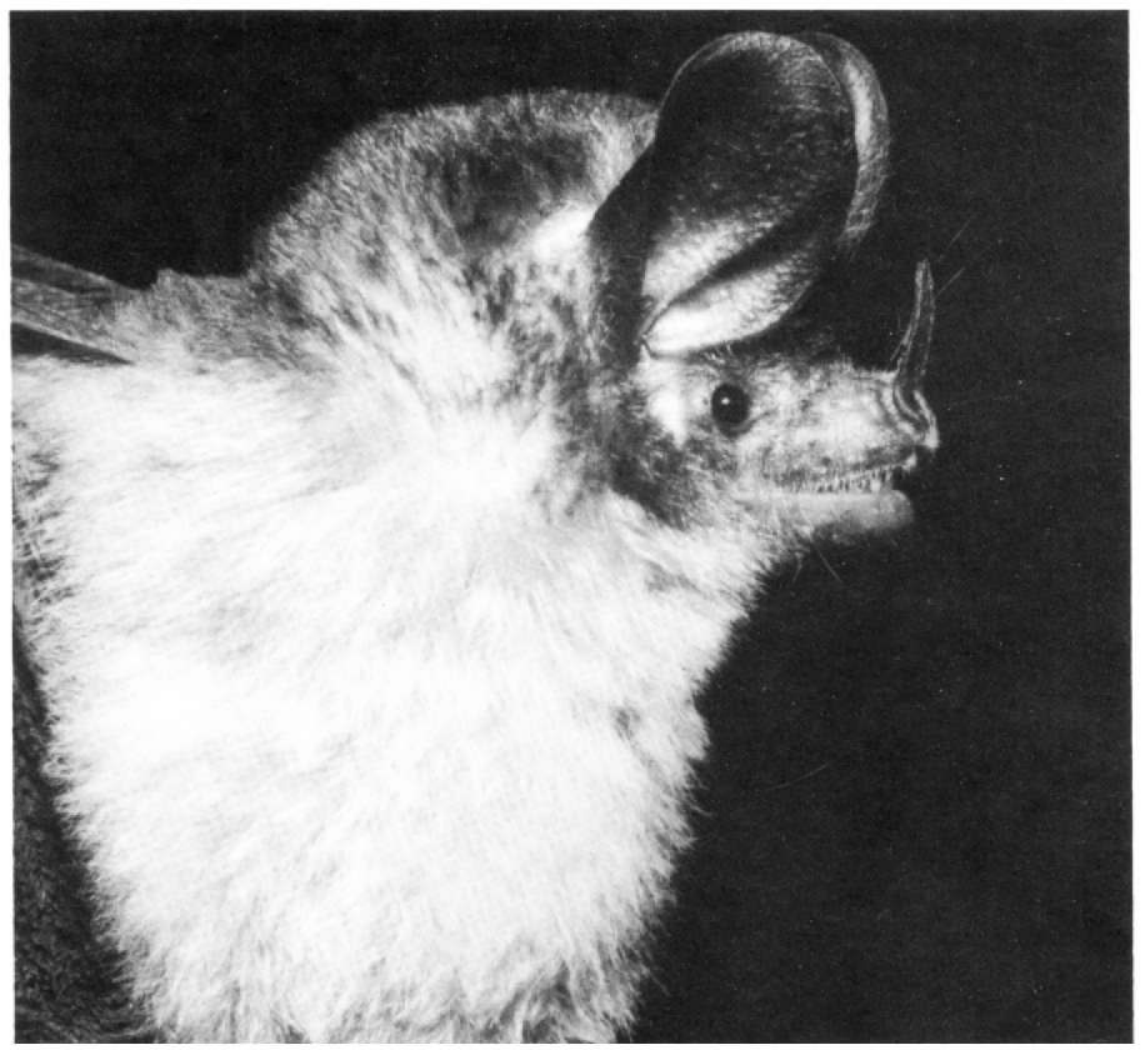

Fig. 28. Schmidt's large-eared bat, Micronycteris schmidtorum. Photo by B. L. Clauson.

\section{Micronycteris schmidtorum Schmidt's Large-eared Bat}

Schmidt's large-eared bat, a monotypic species, ranges from Cozumel Island, Mexico, south to Venezuela (Fig. 28). Information on natural history is scanty. Handley's (1976) Venezuelan collection includes specimens from a variety of habitat types. He also reported individuals roosting in tree holes, and they have been taken from hollow trees in Costa Rica (Starrett and Casebeer 1968). This species is insectivorous, but Gardner (1977) also suggested that individuals may take fruit on occasion. Nothing is known about the reproductive cycle.

Starrett and Casebeer (1968) reported the first Costa Rican specimens from Guanacaste Province. Mares and Wilson (1971) reported the first La Selva record. Our single specimen from Braulio Carrillo was netted in primary forest at $300 \mathrm{~m}$.

An adult male bat fly, Trichobius sp., was collected from $M$. schmidtorum.

Specimens examined (2)-7.3 mi SE of Puerto Viejo [1 female, TTU]; $11 \mathrm{~km} \mathrm{S.}$ $4.5 \mathrm{~km} \mathrm{~W}$ of Puerto Viejo, $300 \mathrm{~m}$ [1 male, USNM]. 


\section{Mimon cozumelae \\ Cozumel Spear-nosed Bat}

Cozumel spear-nosed bats are found from Oaxaca and Veracruz, Mexico, to Colombia (Fig. 29). The species is monotypic. Mimon cozumelae is sometimes considered a subspecies of $M$. bennettii, a species otherwise confined to South America. A systematic review of this relationship would be in order.

This species normally is found in primary forest. Roosts have been found in caves, mines, culverts (Handley 1966), and hollow logs (LaVal 1977). Gardner (1977) suggested that the diet includes insects and fruit. Wilson (1979) noted that this species produces a single young per year, at the beginning of the rainy season.

The first specimen from La Selva and from Costa Rica was reported by Gardner et al. (1970). We caught another in 1973, and LaVal and Fitch (1977) reported 16 from La Selva. All were taken in primary forest.

Specimens examined (2)-Finca La Selva, $3 \mathrm{~km} \mathrm{~S}$ of Puerto Viejo, $70 \mathrm{~m}$ [2 males, MSB].

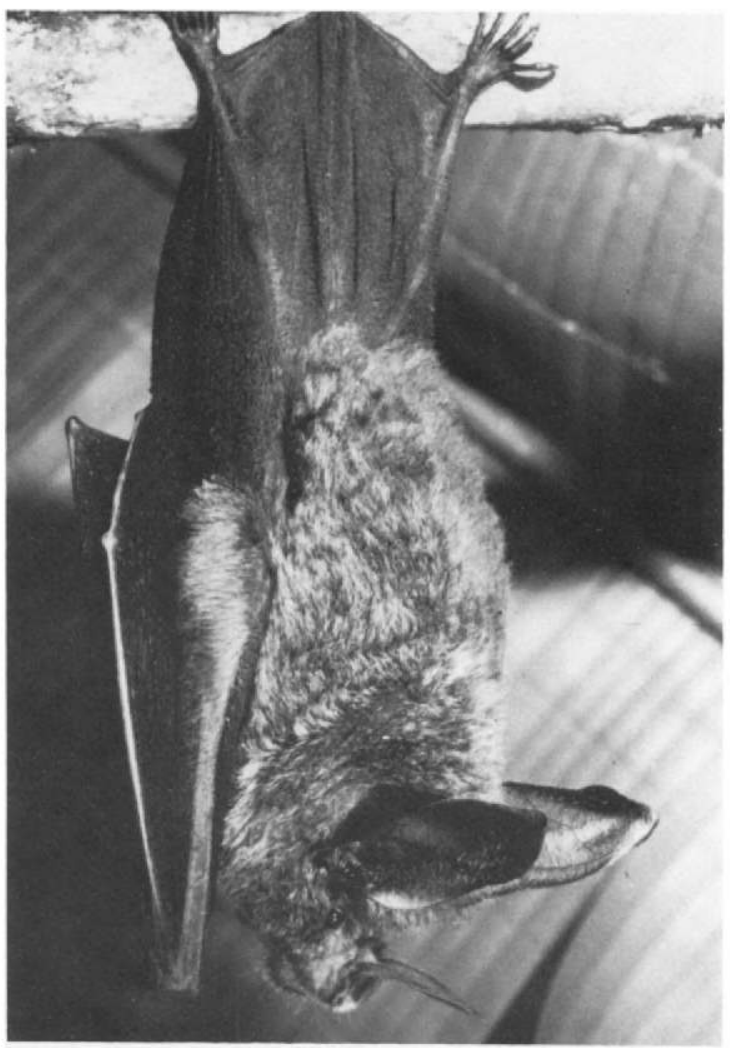

Fig. 29. Cozumel spearnosed bat, Mimon cozumelae. Photo by $R$. K. LaVal. 


\section{Mimon crenulatum \\ Striped Spear-nosed Bat}

Striped spear-nosed bats are found from Chiapas and the Yucatán Peninsula, Mexico, to Brazil (Fig. 30). The subspecies Mimon crenulatum keenani is found throughout Central America.

Primarily an inhabitant of forested areas, this species also is known from banana groves (Gardner et al. 1970). Roosts have been found in hollow trees and buildings (Goodwin and Greenhall 1961). Apparently this species is known to eat only insects (Gardner 1977). Reproductive data are too few to speculate on the cycle, but pregnant females are known from Costa Rica at the beginning of the rainy season (Wilson 1979).

Striped spear-nosed bats first were reported from Costa Rica by Gardner et al. (1970) by four specimens from Cariari. LaVal (1977) took 10 individuals in bat traps in primary forest. We obtained one species of bat fly, Basilia tiptoni (1 male, 1 female), from $M$. crenulatum at La Selva.

Specimen examined (1)-Finca La Selva, $3 \mathrm{~km} \mathrm{~S}$ of Puerto Viejo, $70 \mathrm{~m}$ [1 male, MSB].

Additional record (1)-2.5 km SE of Puerto Viejo [1 female, TCWC].

Fig. 30. Striped spear-nosed bat, Mimon crenulatum. Photo by R. K. LaVal. 


\section{Phylloderma stenops Northern Spear-nosed Bat}

Northern spear-nosed bats are found from Chiapas, Mexico, to Brazil (Fig. 31). The Costa Rican subspecies, Phylloderma stenops septentrionalis, occurs throughout Central America and was originally described as a distinct species.

This poorly known bat has been recorded from a variety of forested and agricultural habitats, but little information on its biology is available. Roosts are as yet unknown. Food items include insect and plant materials (Jeanne 1970; LaVal 1977). The reproductive cycle is unknown, but LaVal (1977) reported capturing a pregnant female during the dry season (early February) in Costa Rica.

This species first was recorded from Costa Rica by LaVal (1977), who caught an adult female in a bat trap alongside a small stream at La Selva. She was pregnant with a single embryo, $33 \mathrm{~mm}$ in crown-rump length, on 9 February 1974 . One species of bat fly, Strebla christinae ( 4 males), was collected from this bat.

Specimen examined (1)-Finca La Selva, $3 \mathrm{~km} \mathrm{~S}$ of Puerto Viejo, $70 \mathrm{~m}$ [1 female, KU].

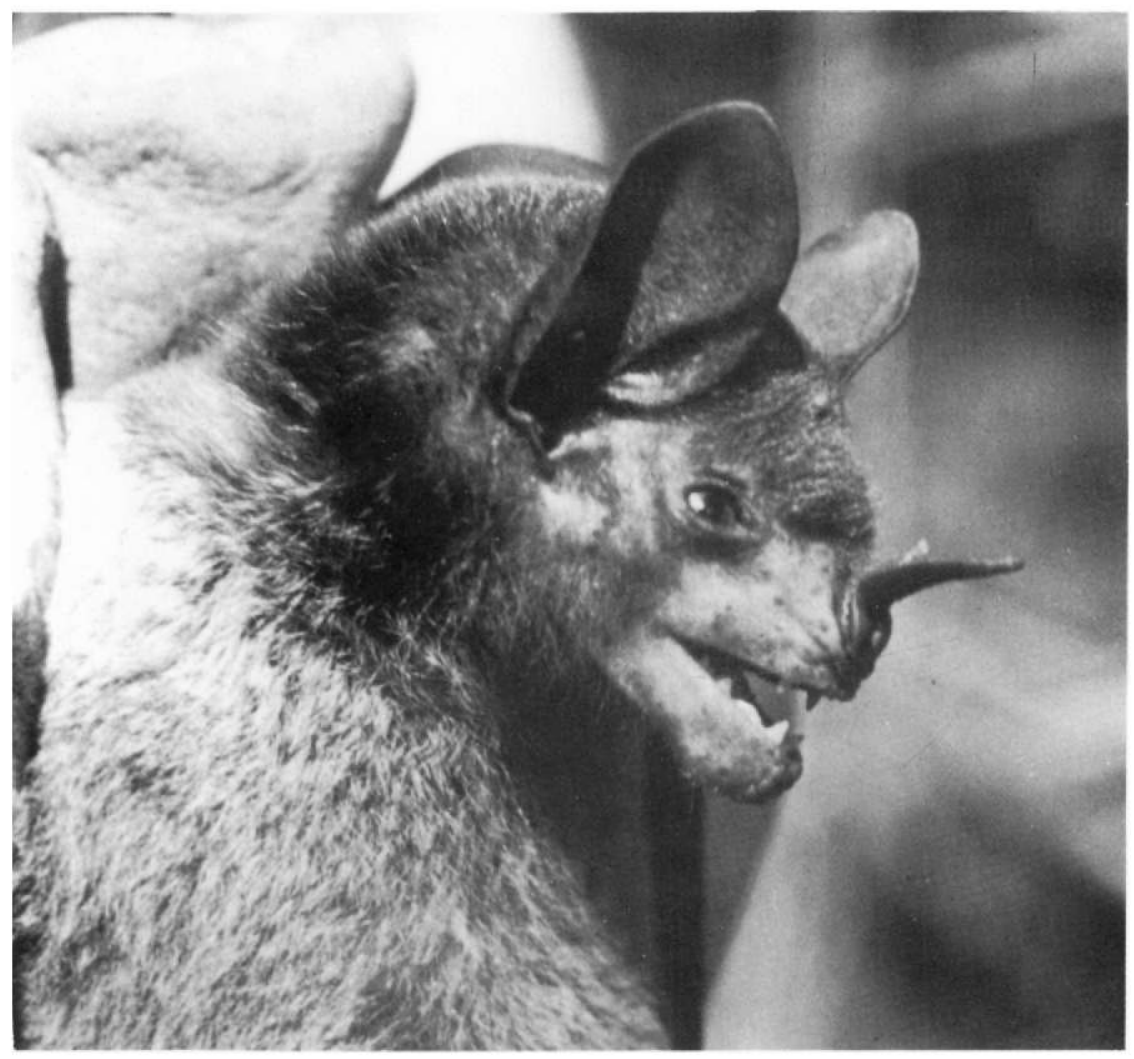

Fig. 31. Northern spear-nosed bat, Phylloderma stenops. Photo by R. K. LaVal. 


\section{Phyllostomus discolor Pale Spear-nosed Bat}

Pale spear-nosed bats are found from Oaxaca and Veracruz, Mexico, throughout Central America to northern Argentina (Fig. 32). The Costa Rican subspecies, Phyllostomus discolor verrucosus, occurs throughout Central America.

This species is associated with a variety of habitats (Williams and Genoways 1980). Roosting sites include hollow trees and caves (Goodwin and Greenhall 1961). Food items include insects, fruit, flowers, pollen, and nectar (Gardner 1977). Despite numerous records of this common species, the reproductive cycle remains enigmatic. Heithaus et al. (1975) suggested that $P$. discolor may be monestrous in Costa Rica.

Davis and Carter (1962) reported a male from Guanacaste Province. LaVal and Fitch (1977) captured one at La Selva, but apparently there are no preserved specimens from the Caribbean lowlands of Costa Rica.

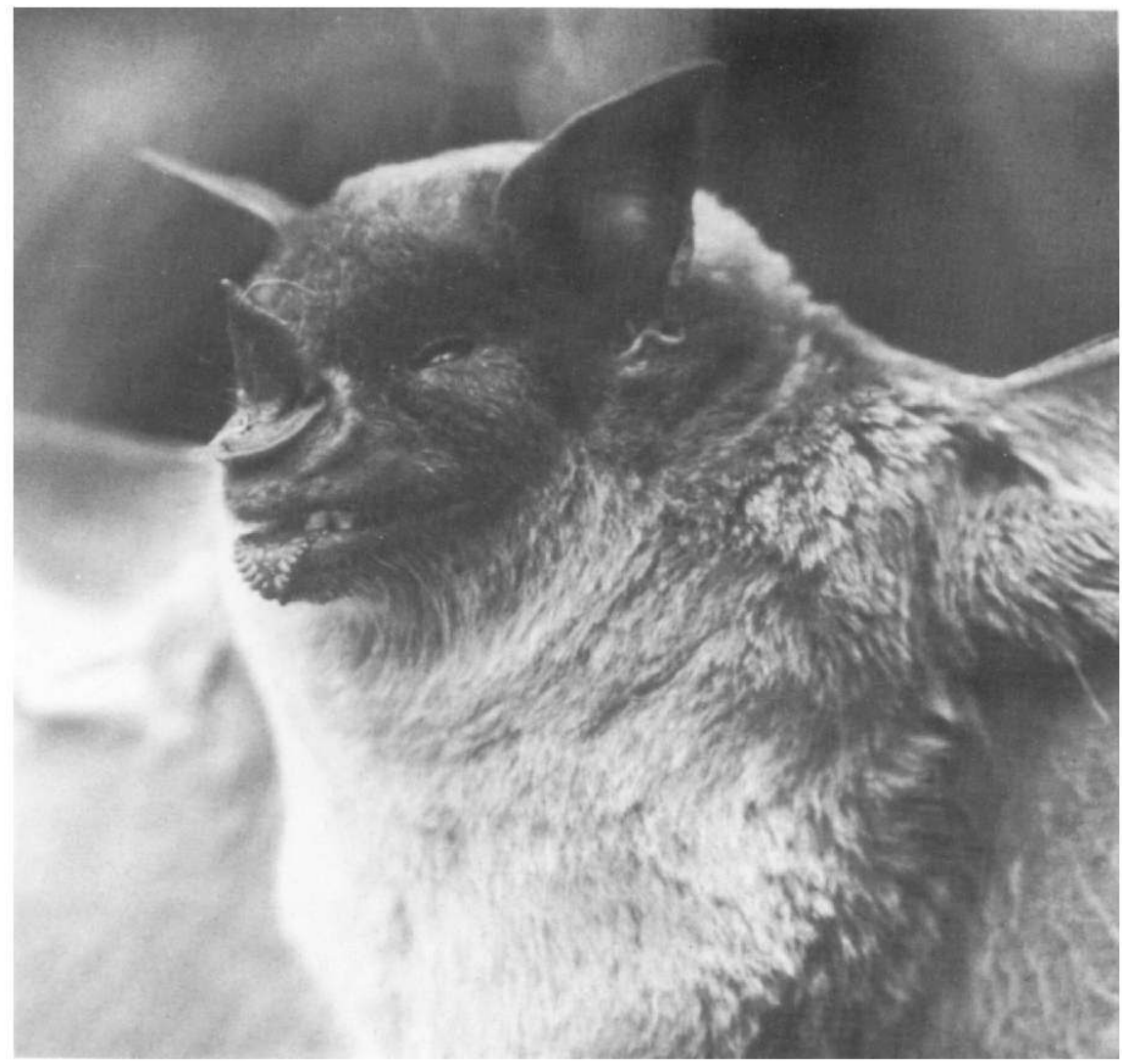

Fig. 32. Pale spear-nosed bat, Phyllostomus discolor. Photo by R. K. LaVal. 


\section{Phyllostomus hastatus \\ Big Spear-nosed Bat}

Big spear-nosed bats are known from Honduras to Brazil (Fig. 33). The Costa Rican subspecies, Phyllostomus hastatus panamensis, is found throughout Central America.

This widespread species has been reported from a number of habitats. Roosting sites include caves, hollow trees, buildings, termite nests, thatched roofs, and foliage (Tuttle 1976). Like other members of the genus, $P$. hastatus feeds on a wide variety of items including insects, small vertebrates, fruit, flowers, nectar, and pollen (Gardner 1977). Wilson (1979) suggested a geographically variable reproductive pattern with some populations monestrous and others bimodally polyestrous.

We captured a single, nonreproductive adult female at La Selva on 1 August 1988 in the clearing around the field station. Although this species is presumed to be widespread in Costa Rica, there are few published records or specimens from the country. Starrett and de la Torre (1964) reported two specimens from Turrialba. LaVal and Fitch (1977) captured one individual at La Selva.

Specimens examined (2)-Finca La Selva, $3 \mathrm{~km} \mathrm{~S}$ of Puerto Viejo, $70 \mathrm{~m}$ [2 males, LACM].

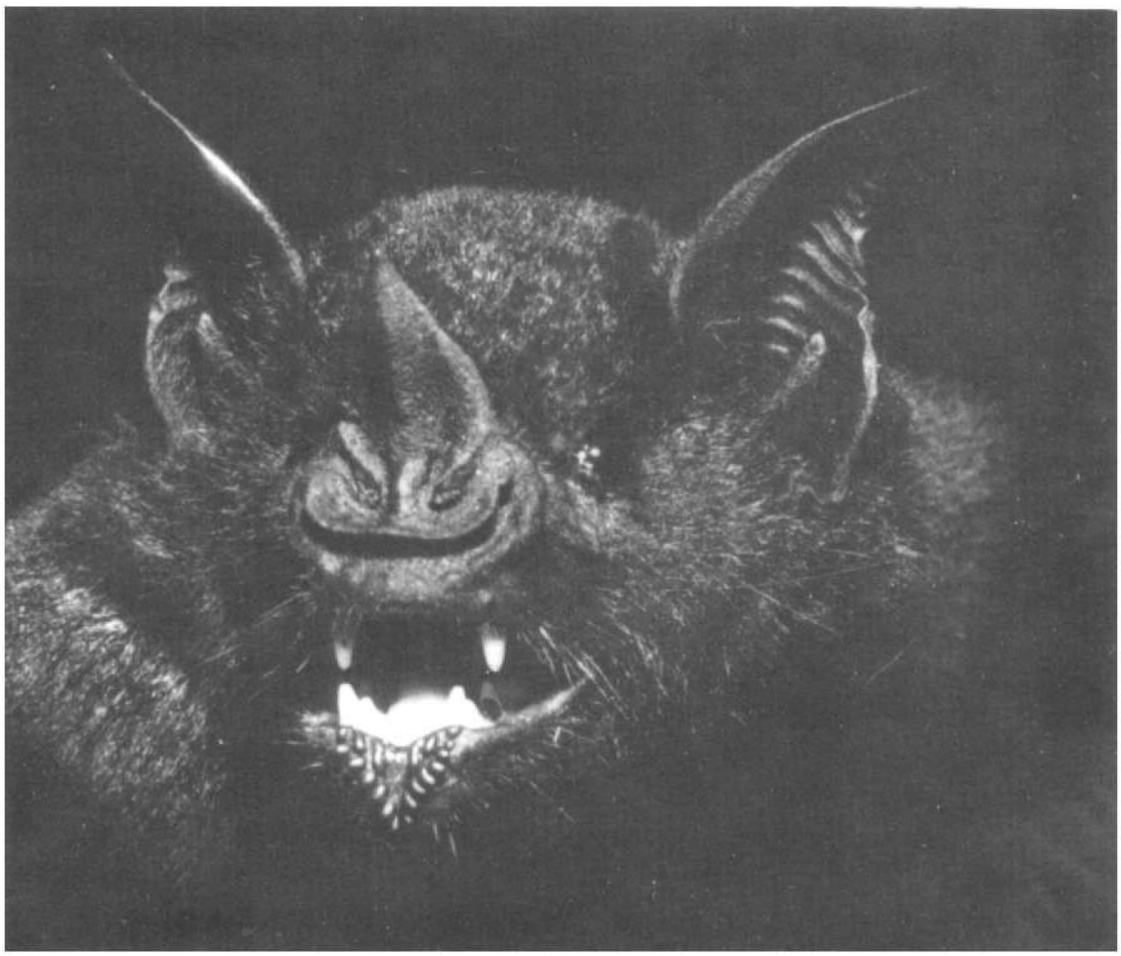

Fig. 33. Big spear-nosed bat, Phyllostomus hastatus. Photo by B. L. Clauson. 


\section{Tonatia bidens \\ Spix's Round-eared Bat}

Spix's round-eared bats are found from eastern Guatemala to Paraguay (Fig. 34). The recent taxon is monotypic, although there is a fossil subspecies known from Jamaica (Koopman 1976).

This is basically a species of primary forest, but there are records from agricultural areas (Handley 1976). The only known roosts are in hollow trees (Goodwin and Greenhall 1961). Fruit and insects have been reported as food items (Gardner 1977). The reproductive pattern is likely one of bimodal polyestry (Wilson 1979).

Goodwin (1946) reported the species from Palmar, and Gardner et al. (1970) added a specimen from Quepos, both in the Pacific lowlands. LaVal (1977) captured 15 from La Selva. Our specimens from Braulio Carrillo were mist-netted over streams and trails in primary forest.

Bat flies collected from Tonatia bidens at La Selva include Strebla galindoi (4 males, 2 females) and an undescribed species of Trichobius ( 7 males, 12 females).

Specimens examined (8)-Finca La Selva, $3 \mathrm{~km} \mathrm{~S}$ of Puerto Viejo, $70 \mathrm{~m}$ [1 male, KU; 2 males, MSB]; $11 \mathrm{~km} \mathrm{S,} 4.5 \mathrm{~km} \mathrm{~W}$ of Puerto Viejo, $270 \mathrm{~m}$ [2 males, 2 females, USNM; 1 female, UNA].

Fig. 34. Spix's roundeared bat, Tonatia bidens. Photo by B. L. Clauson.

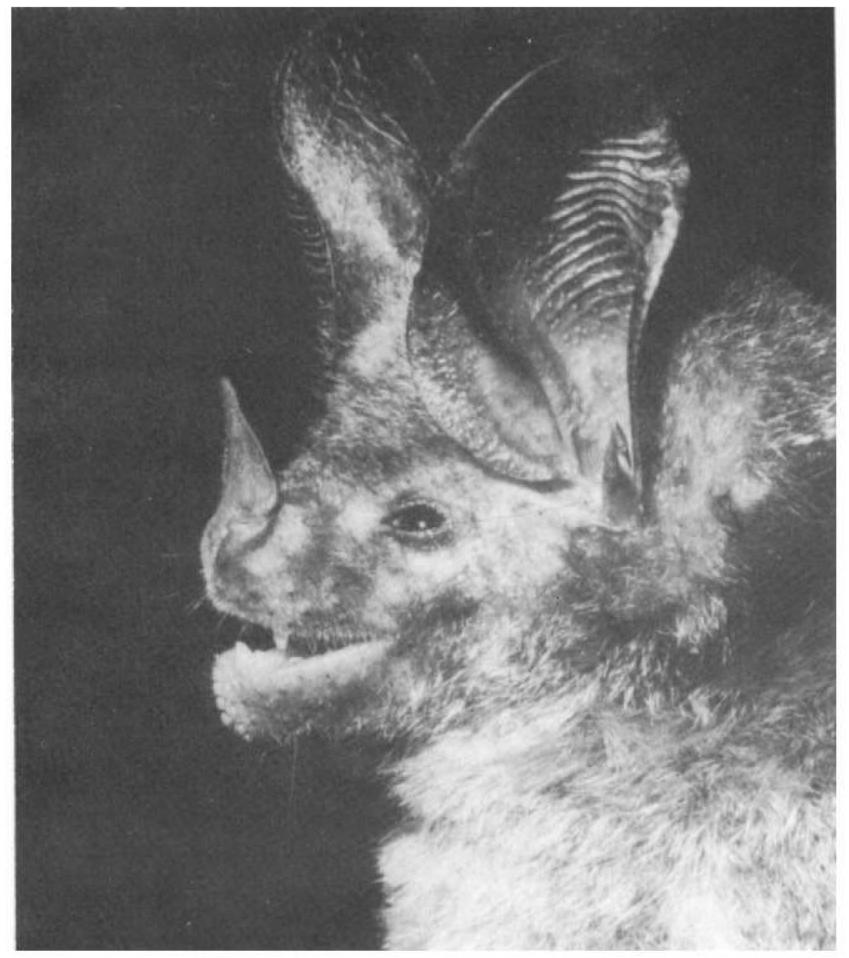




\section{Tonatia brasiliensis \\ Pygmy Round-eared Bat}

Pygmy round-eared bats are distributed from Veracruz, Mexico, to Brazil (Fig. 35). The species is monotypic although, at one time, four separate species were recognized. Names previously used for this species in Costa Rica include Tonatia minuta and $T$. nicaraguae.

In Costa Rica, this species usually is found in forested habitats, but it is known from agricultural areas as well. The only known roosting sites are termite nests (Goodwin and Greenhall 1961). Gardner (1977) suggested that the species probably feeds on insects and fruit. These bats probably have a bimodally polyestrous reproductive cycle (Wilson 1979).

This species was first recorded from Costa Rica by Gardner et al. (1970), based on specimens from the Osa Peninsula and from Cariari in Limón Province. LaVal (1977) captured eight at La Selva, two of which were pregnant females. one in February and one in April. Our specimen was captured using a mist net set over a small stream in an old clearing at $270 \mathrm{~m}$ in Parque Nacional Braulio Carrillo.

Bat flies taken from $T$. brasiliensis were Mastoptera sp. (minuta complex; 2 males and 2 females).

Specimens examined (2)-Finca La Selva, $3 \mathrm{~km} \mathrm{~S}$ of Puerto Viejo, $70 \mathrm{~m}$ [1 male, KU]; $11 \mathrm{~km} \mathrm{~S}, 4.5 \mathrm{~km} \mathrm{~W}$ of Puerto Viejo, $270 \mathrm{~m}$ [1 female, USNM].

Fig. 35. Pygmy round-eared bat, Tonatia brasiliensis. Photo by B. L. Clauson.

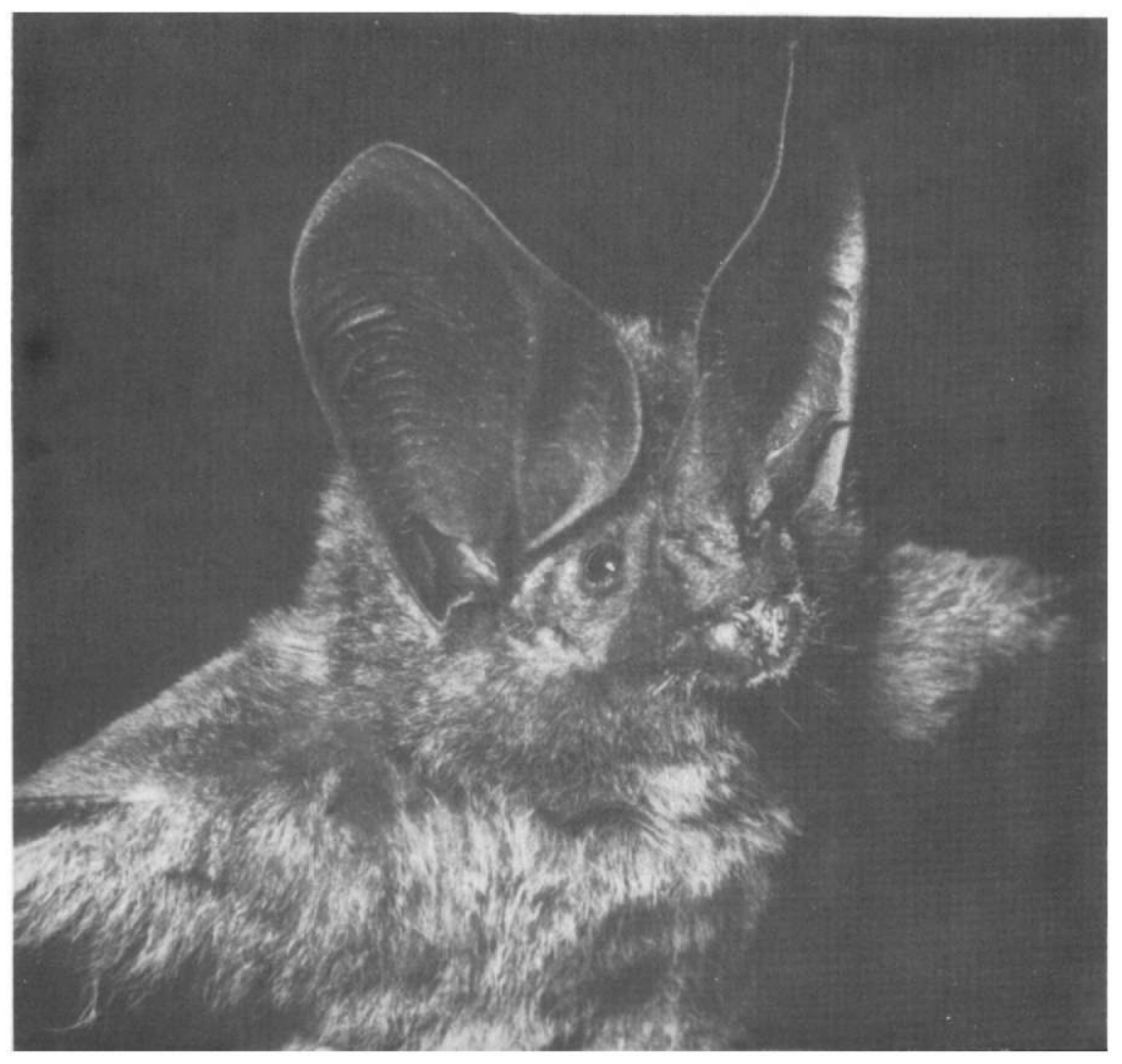




\section{Tonatia silvicola D'Orbigny's Round-eared Bat}

D'Orbigny's round-eared bats are known from Honduras to northern Argentina (Fig. 36). The single subspecies in Costa Rica, Tonatia silvicola centralis, also is known from Nicaragua and Honduras (Davis and Carter 1978).

This species has been collected in a variety of habitats ranging from primary forest to agricultural clearings (Hill 1964). Termite nests and tree holes are used as roosting sites (McCarthy et al. 1983; Graham 1988). Insects and fruit are eaten (Fleming et al. 1972). Wilson (1979) reported evidence of only one young per year for this species.

Although several individuals were captured in Guanacaste by various OTS participants in the early 1970 's, apparently no specimens were preserved. LaVal (1977) captured one at La Selva, but also did not preserve it. It is possible that there are no preserved specimens of this species available from Costa Rica.

Fig. 36. D'Orbigny's round-eared bat, Tonatia silvicola. Photo by D. E. Wilson. 


\section{Trachops cirrhosus \\ Fringe-lipped Bat}

Fringe-lipped bats are found from Oaxaca and Veracruz, Mexico, to Brazil (Fig. 37). The nominate subspecies is found throughout Costa Rica, and extends southward into South America.

This is a bat of forested regions, and is known to frequent streams and swampy areas (Tuttle 1970). Caves, houses, culverts, and hollow trees are used as roosting sites (Handley 1966). In addition to feeding on insects and lizards, these bats are specialists on frogs (Tuttle and Ryan 1981). The reproductive cycle is poorly known.

The fringe-lipped bat first was recorded from Costa Rica by Davis and Carter (1962), who captured a single female in Guanacaste. Starrett and Casebeer (1968) added numerous specimens from the Pacific versant. Gardner et al. (1970) reported the first specimen from La Selva. We have netted individuals infrequently at $\mathrm{La}$ Selva over the years. The specimen from Parque Nacional Braulio Carrillo was taken in a mist net over a small stream in an old clearing. One species of bat fly, an undescribed Trichobius closely related to $T$. ethophalalus ( 1 male, 1 female), was collected from a single $T$. cirrhosus at La Selva.

Specimens examined (5)-Finca La Selva, $3 \mathrm{~km} \mathrm{~S}$ of Puerto Viejo, $70 \mathrm{~m}$ [2 males, $1 \mathrm{sex}$ ?, MSB]; $1 \mathrm{~km} \mathrm{~S}, 11.5 \mathrm{~km}$ E of San Miguel, $680 \mathrm{~m}$ [1 male, USNM]; $3.5 \mathrm{~km} \mathrm{S,} 11.5 \mathrm{~km}$ E of San Miguel, $1,000 \mathrm{~m}$ [1 female, UNA].

\section{Vampyrum spectrum False Vampire Bat}

False vampire bats are found from Veracruz, Mexico, to southwestern Brazil (Fig. 38). The species is monotypic.

Although these predatory bats normally occur in small numbers in primary forest, they have been recorded from a wide variety of habitats (Navarro L. and Wilson 1982). Vehrencamp et al. (1977) studied food habits of a pair of false vampire bats found using a hollow tree roost in Guanacaste Province by studying remains of prey species. They documented predation on a variety of small birds and speculated on foraging behavior. Other prey items include rodents, other bats, and possibly large insects (Bradbury 1983b; McCarthy 1987). Details of the reproductive cycle are unknown.

The first Costa Rican specimen of Vampyrum spectrum was taken at Lepanto on the Nicoya Peninsula by a German physician, Dr. Carl Hoffmann, who had moved to Costa Rica in 1858. Casebeer et al. (1963) captured the first specimen from La Selva and the Caribbean lowlands of Costa Rica in 1961. We captured an adult female in primary forest at La Selva in July 1973, and an adult male and lactating female there on 8 July 1974. Additionally, Levey (in litt.) captured one on the path just over the Sura bridge at $2330 \mathrm{~h}$ on 5 August 1981, and Reid (in litt.) captured a female near the field station on 7 December 1988. In Parque Nacional Braulio Carrillo, we caught a single adult female in a mist net set on a ridgetop trail in good forest above the Río Cantarrana at $300 \mathrm{~m}$. She made several passing flights near a cloth bag containing other live bats before becoming en- 


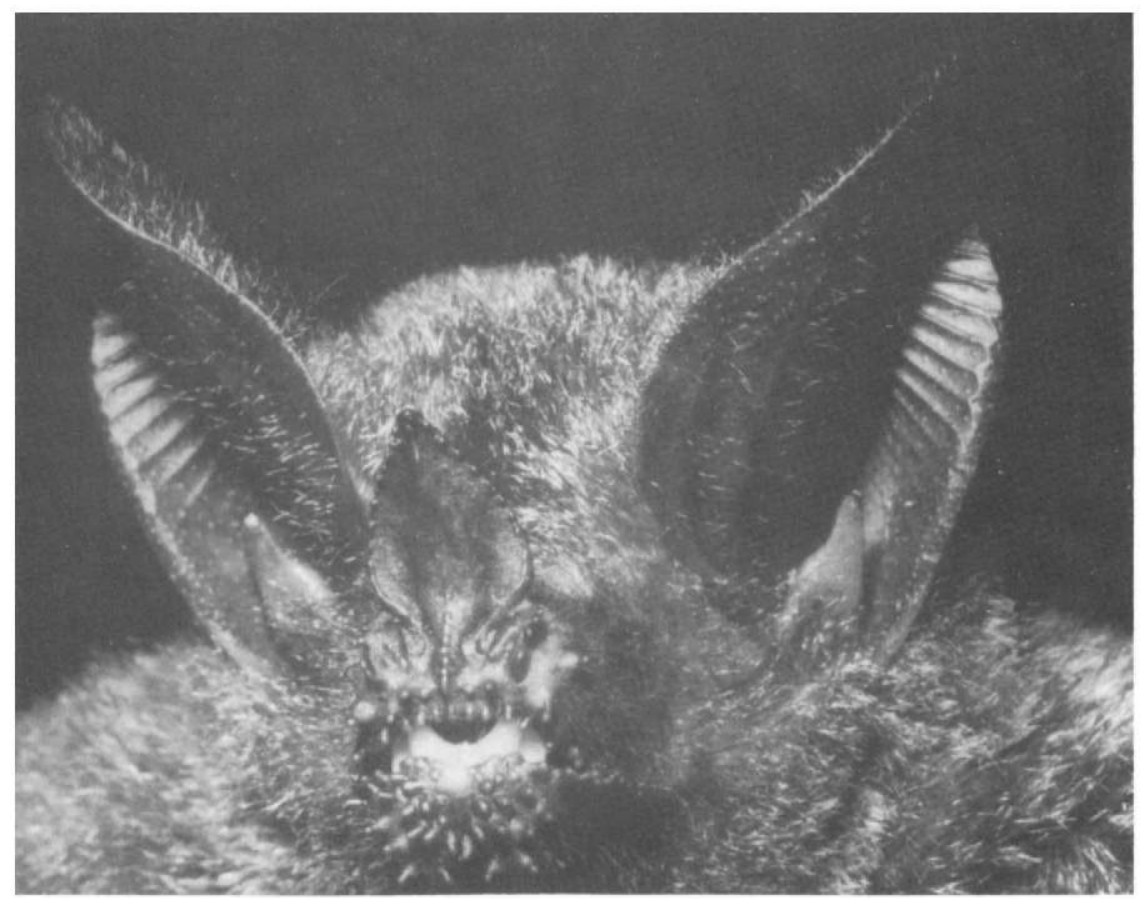

Fig. 37. Fringe-lipped bat, Trachops cirrhosus. Photo by B. L. Clauson.

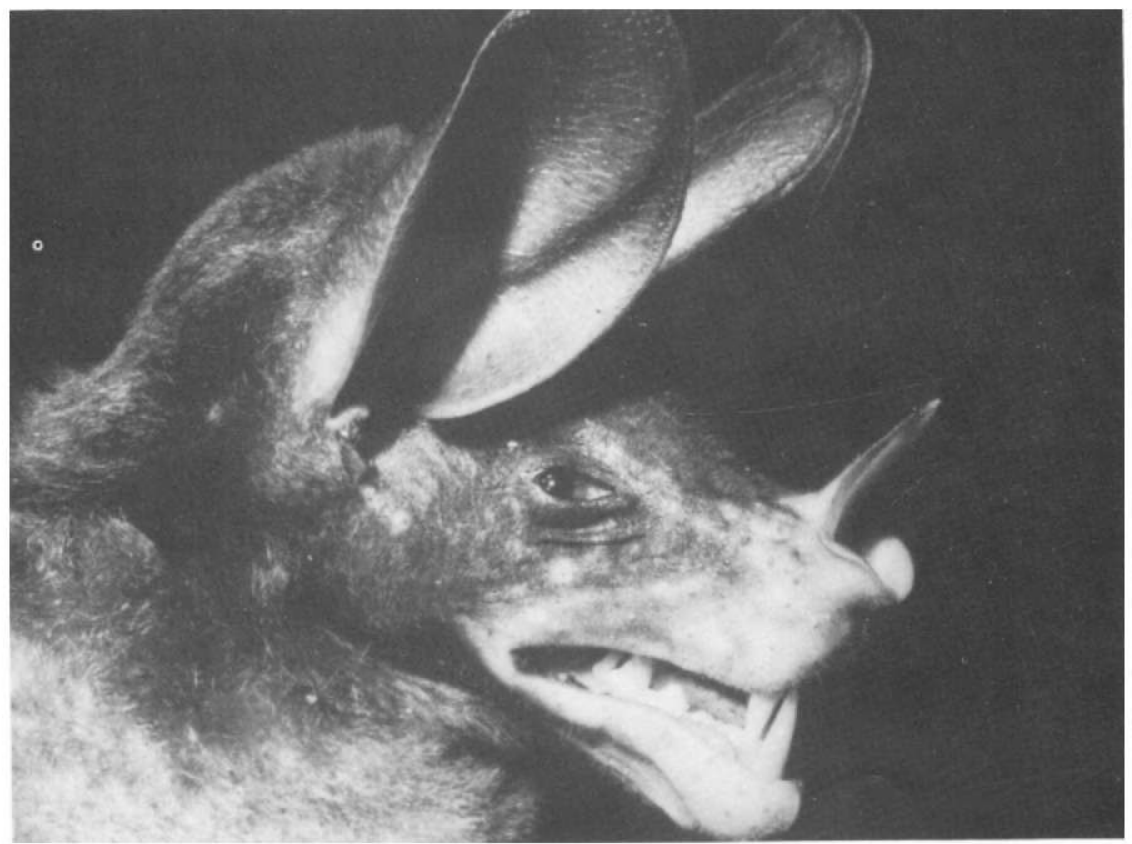

Fig. 38. False vampire bat, Vampyrum spectrum. Photo by B. L. Clauson. 
tangled in the nearby net. LaVal and Fitch (1977) reported catching four false vampires at La Selva during their study.

Specimens examined (3)-Finca La Selva, $3 \mathrm{~km} \mathrm{~S}$ of Puerto Viejo, $70 \mathrm{~m}$ [1 male, KU; 1 female, MSB]; $11 \mathrm{~km} \mathrm{S,} 4.5 \mathrm{~km} \mathrm{~W}$ of Puerto Viejo, $300 \mathrm{~m}$ [1 female, USNM].

\section{Subfamily Glossophaginae}

\section{Anoura cultrata \\ Handley's Tailless Bat}

Handley's tailless bat reaches the northern limit of its known distribution in Costa Rica; it occurs southward in South America along the Andes to Bolivia (Fig. 39). Anoura cultrata is monotypic (Nagorsen and Tamsitt 1981), although specimens from the Cordillera de Talamanca originally were named as a separate species, A. werckleae (Starrett 1969).

Curiously enough, Handley's tailless bats have a small but obvious tail. This species occupies a variety of habitats, and has been taken at 2,600 m, near the upper elevational limits known for bats in Costa Rica (Gardner et al. 1970). The only reported roosting sites are in caves (Handley 1976). Food items include pollen, nectar, and insects (Gardner 1977). The reproductive cycle is unknown, but available records were summarized by Tamsitt and Nagorsen (1982).

Carter et al. (1966) reported the first Costa Rican specimen, a male from Alajuela Province. Gardner et al. (1970) recorded a female from Vara Blanca, near Braulio Carrillo. Our specimens were taken in mist nets set over small streams in old clearings. Ectoparasites collected from $A$. cultrata include the streblid bat flies Anastrebla mattadeni ( 8 males, 2 females) and Exastinion oculatum (11 males, 9 females).

Specimens examined (17)-1 km S, $11.5 \mathrm{~km} \mathrm{~W}$ of San Miguel, $680 \mathrm{~m}$ [5 males, 6 females, USNM; 4 males, UNA]; $3.5 \mathrm{~km} \mathrm{~S}, 11.5 \mathrm{~km}$ W of San Miguel, $1,000 \mathrm{~m}$ [1 male, USNM]; Vara Blanca [1 female, LSUMZ].

\section{Anoura geoffroyi Geoffroy's Tailless Bat}

Geoffroy's tailless bats are found from Sinaloa and Tamaulipas, Mexico, to northern Argentina (Fig. 40). The Costa Rican subspecies, Anoura geoffroyi lasiopyga, is the race occurring in Mexico and Central America.

A variety of habitats are occupied extending over an elevational range up to at least 2,550 m (Handley 1976). Caves and tunnels are used as roosts (Tuttle 1970). These bats are known to eat pollen, nectar, fruit, and insects (Gardner 1977). This species may be seasonally monestrous, an unusual pattern for phyllostomids (Wilson 1979). Anoura geoffroyi is the common species on the Pacific slopes and is mostly replaced by $A$. cultrata on the Caribbean slopes.

Although not uncommon in Costa Rica, specimens of this species rarely have been recorded in the literature. Mares and Wilson (1971) listed 3 from Puntarenas Province, and LaVal (1977) added 13 from Monteverde. Our single specimen came from a mist net set in an old clearing bordered by a small stream.

Specimen examined (1)-5 km E of Vara Blanca, 2,050 m [1 female, USNM]. 


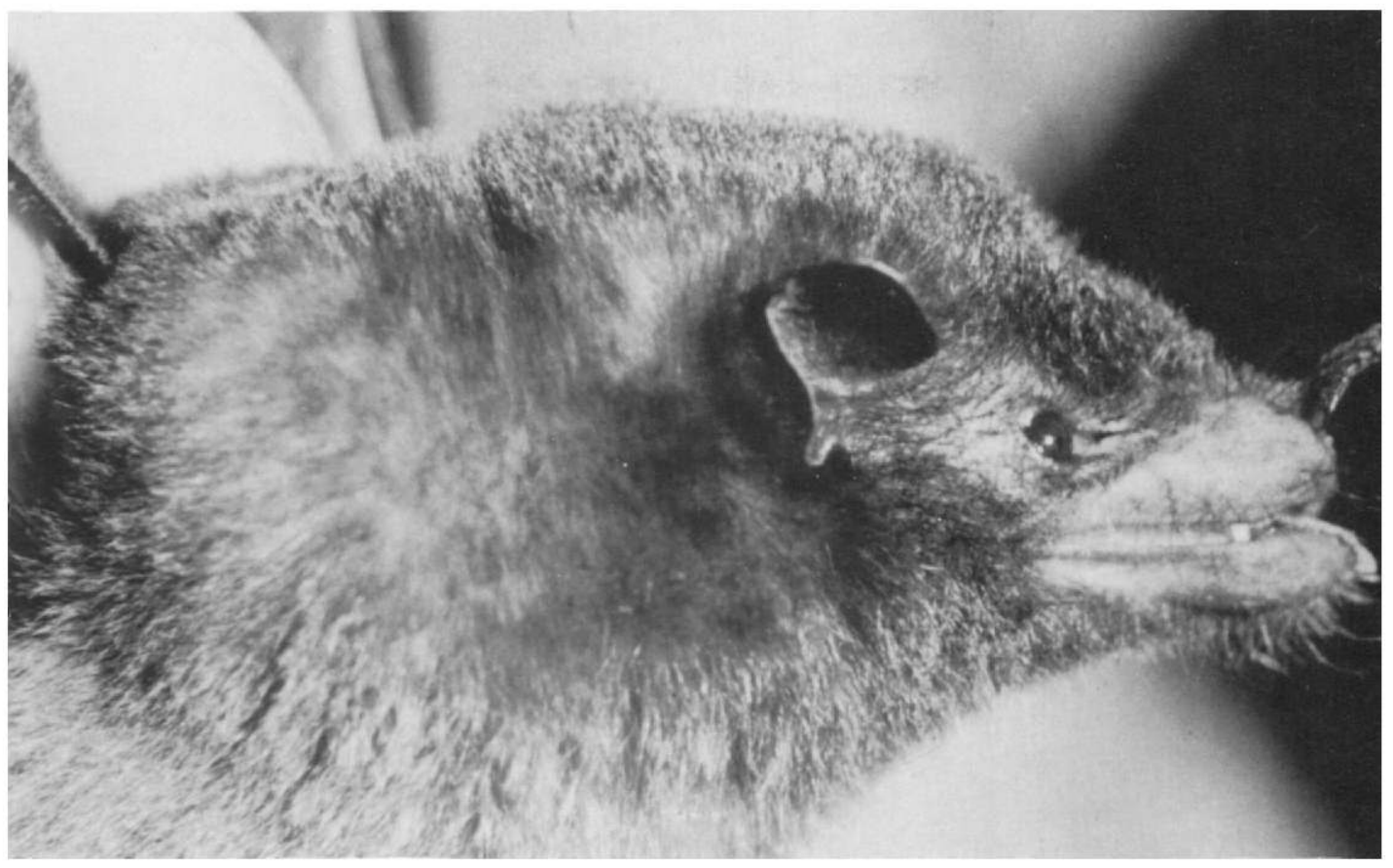

Fig. 39. Handley's tailless bat, Anoura cultrata. Photo by R. K. LaVal.

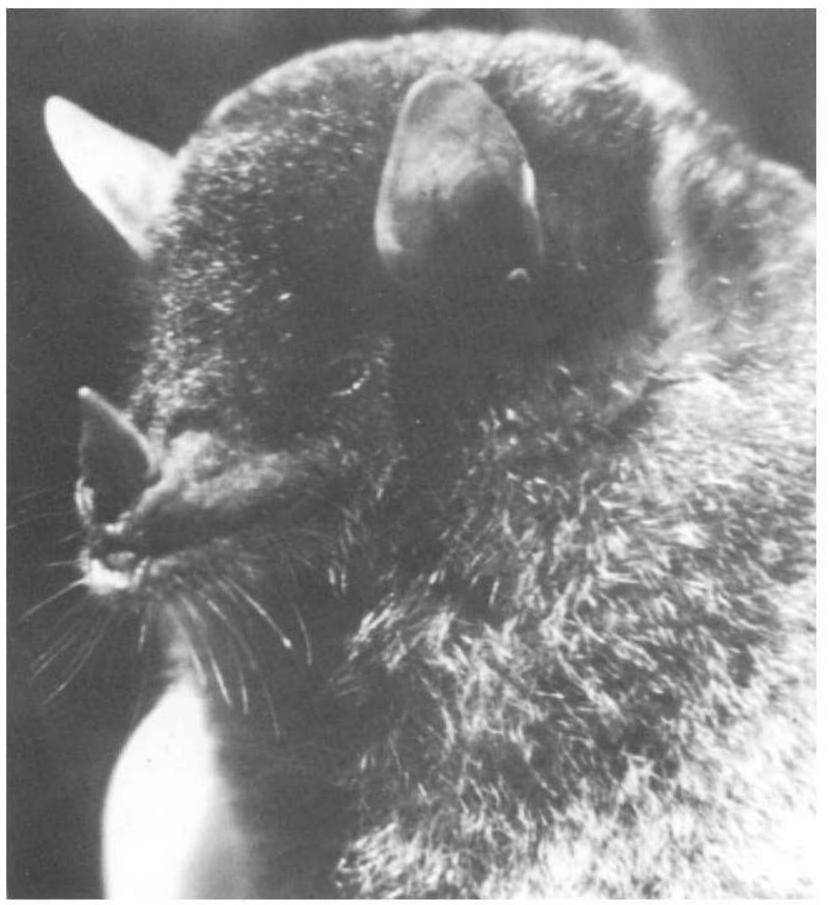

Fig. 40. Geoffroy's tailless bat, Anoura geoffroyi. Photo by R. K. LaVal. 


\section{Choeroniscus godmani \\ Godman's Bat}

Godman's bats are found from Sinaloa, Mexico, to Suriname (Fig. 41). The species is monotypic.

These bats occupy a variety of habitats ranging from primary forest to agricultural areas; roosting sites have not been recorded. Food probably includes pollen, nectar, and insects (Gardner 1977). Other than the observation that young seem to be weaned at the beginning of the rainy season, little is known of the reproductive cycle (Wilson 1979).

Goodwin (1946) listed four specimens from San José Province and Gardner et al. (1970) added four more from Cartago and Guanacaste Provinces. LaVal and Fitch (1977) captured and released three at La Selva; however, none were preserved.

\section{Glossophaga commissarisi Commissaris' Long-tongued Bat}

Commissaris' long-tongued bats occur from Sinaloa and Veracruz, Mexico, to Brazil and Peru. The nominate subspecies, Glossophaga commissarisi commissarisi, is found throughout Central America.

These bats have been collected in a variety of habitats ranging from primary forest to banana groves and clearings. Known roost sites seem to be limited to caves and tunnels (Jones et al. 1972), although we found them to be common where there are no caves or tunnels. Food includes insects, fruit, pollen, and nectar (Gardner 1977). The reproductive cycle is one of bimodal polyestry (Wilson 1979).

This species is quite common at La Selva, where it first was recorded by Mares and Wilson (1971). LaVal and Fitch (1977) captured 81 there. Curiously, we did not encounter $G$. commissarisi in Braulio Carrillo.

Specimens examined (12)-Puerto Viejo, Río Sarapiquí, $300 \mathrm{ft}$ [2 females, UMMZ]; Puerto Viejo, $100 \mathrm{~m}$ [1 male, KU]; Finca La Selva, $3 \mathrm{~km} \mathrm{~S}$ of Puerto Viejo, $70 \mathrm{~m}$ [1 male, KU; 5 males, 3 females, MSB].

Additional records (1) $-3 \mathrm{mi} \mathrm{N}$ of Heredia, 5,600 $\mathrm{ft}$ [1 male, TCWC].

\section{Glossophaga soricina}

\section{Pallas' Long-tongued Bat}

Pallas' long-tongued bats ate distributed from Sonora, Mexico, to northern Argentina (Fig. 42). The Costa Rican subspecies, Glossophaga soricina handleyi, is found throughout Central America.

This is one of the most widespread and abundant species of bats in the tropical lowlands and occurs in almost every available habitat type. It is known to roost in caves, tunnels, hollow trees, buildings, and culvert, (Tuttle 1976). Food items include insects, fruit, pollen, nectar, and flowers (Gardner 1977). The reproductive pattern is one of bimodal polyestry (Wilson 1979). Howell (1983) summarized natural history information.

This species is common at La Selva, but less so than G. commissarisi. We captured several there in 1973 and 1974, and LaVal and Fitch (1977) recorded 23. Although we did not encounter them in Braulio Carrillo, a specimen taken at 


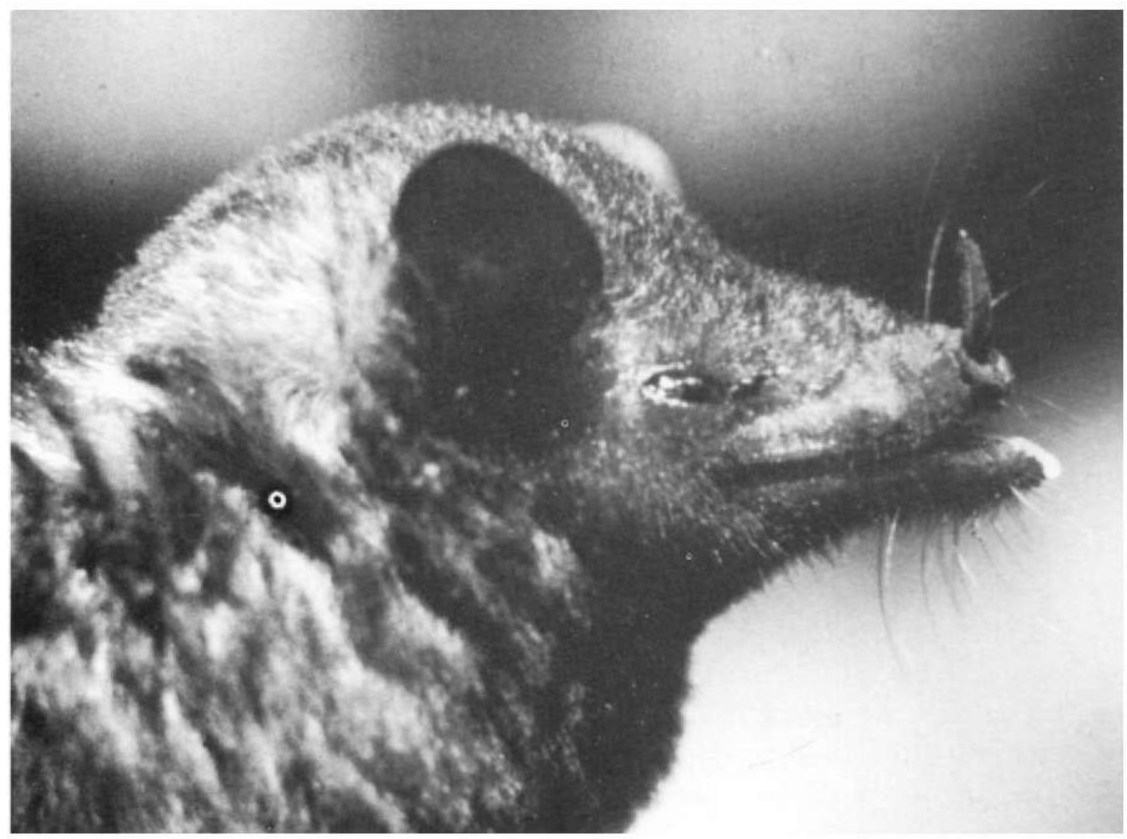

Fig. 41. Godman's bat, Choeroniscus godmani. Photo by R. K. LaVal.

Fig. 42. Pallas' longtongued bat, Glossophaga soricina. Photo by B. L. Clauson.

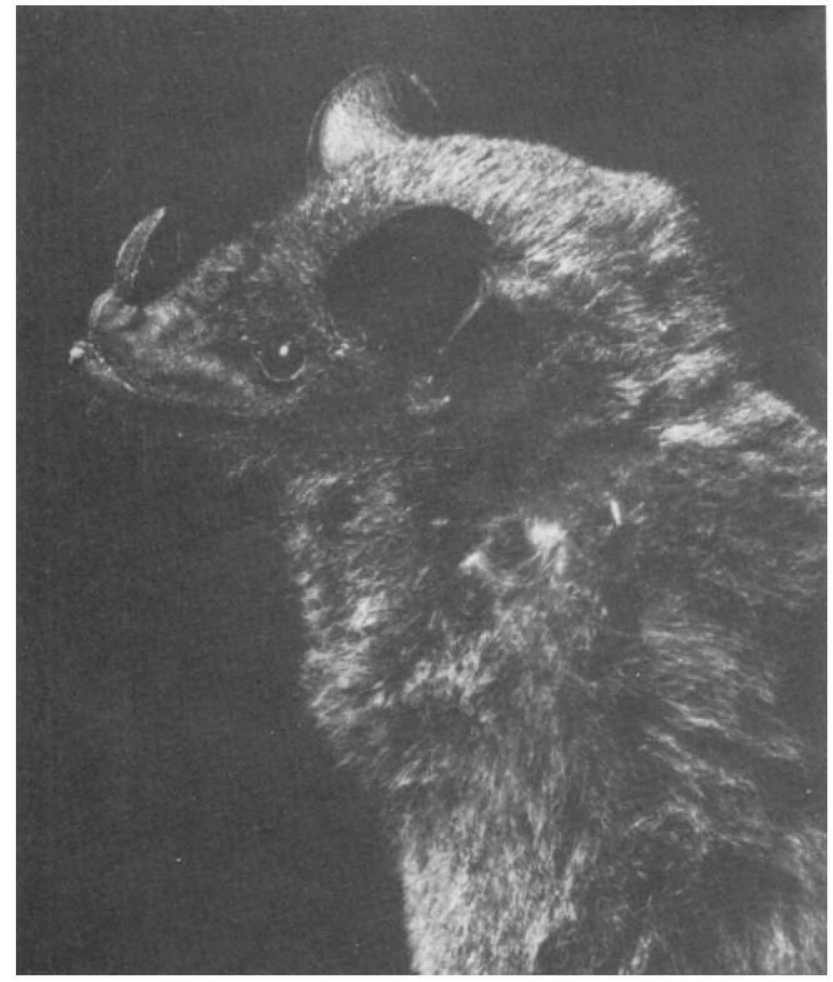


1,520 m near San José de la Montaña (Starrett and de la Torre 1964) suggests that this species occurs at least seasonally at low and middle elevations there.

Specimen examined (1)-Puerto Viejo, $100 \mathrm{~m}$ [1 male, KU].

Additional records (4) $-3 \mathrm{mi} \mathrm{N}$ of Heredia, 5,600 ft [1 male, 3 females, TCWC]; San José de la Montaña, 1,520 m (Starrett and de la Torre 1964).

\section{Hylonycteris underwoodi Underwood's Long-tongued Bat}

Underwood's long-tongued bats occur from Nayarit and Veracruz, Mexico, to western Panama (Fig. 43). The nominate subspecies, Hylonycteris underwoodi underwoodi, is found in Costa Rica and adjacent areas, north to Veracruz.

In general, this species is found in forested habitats, frequently at middle elevations. Roosts have been found in caves, culverts, and hollow logs (Villa-R. 1967). Individuals feed on insects, pollen, and nectar (Gardner 1977). The reproductive cycle is one of bimodal polyestry (Wilson 1979), but pregnant females have been recorded year around (LaVal 1977; LaVal and Fitch 1977). Biology of this species was summarized by Jones and Homan (1974).

The type locality is San José; the first specimens from Vara Blanca, near Parque Nacional Braulio Carrillo, were reported by Gardner et al. (1970). LaVal and Fitch (1977) captured 15 at La Selva. This is the common glossophagine bat in the region, and we netted it in every habitat sampled.

Specimens examined (33)-Finca La Selva, $3 \mathrm{~km} \mathrm{~S}$ of Puerto Viejo, $70 \mathrm{~m}$ [1 female, LACM; 1 male, 1 female, MSB]; $11 \mathrm{~km} \mathrm{S,} 4.5 \mathrm{~km} \mathrm{~W}$ of Puerto Viejo, $270 \mathrm{~m}$ [ 3 males, 2 females, USNM]; $1 \mathrm{~km} \mathrm{S,} 11.5 \mathrm{~km}$ E of San Miguel, $680 \mathrm{~m}$ [1 male, 5 females, USNM; 1 male, UNA]; $3.5 \mathrm{~km} \mathrm{S,} 1.5 \mathrm{~km}$ E of San Miguel, $1,000 \mathrm{~m}$ [6 females, USNM]; $5 \mathrm{~km} \mathrm{E}$ of Vara Blanca, 2,050 $\mathrm{m}$ [ 4 males, 1 female, USNM]; Vara Blanca [1 male, 3 females, LSUMZ]; $1 \mathrm{mi} \mathrm{W}$ of Vara Blanca [3 females, TTU].

\section{Lichonycteris obscura Brown Long-nosed Bat}

The brown long-nosed bat is a monotypic species found from Belize and Guatemala to Peru and the Guianas.

Little natural history information is available for Lichonycteris obscura. Most specimens have been taken in forested habitats. Apparentiy, roosting sites have not been recorded. The diet includes pollen, nectar, and insects (Gardner 1977). In Costa Rica, pregnant females have been taken in the dry season, but the overall reproductive pattern is unknown.

Goodwin reported two specimens from San José Province. Gardner et al. (1970) recorded the first specimens from the Caribbean lowlands at Cariari, Limón Province. LaVal and Fitch (1977) captured three individuals at La Selva.

Specimen examined (1)-Finca La Selva, $3 \mathrm{~km} \mathrm{~S}$ of Puerto Viejo, $70 \mathrm{~m}$ [1 male, LACM].

Additional record (1)-2.5 km SE of Puerto Viejo [1 female, TCWC]. 


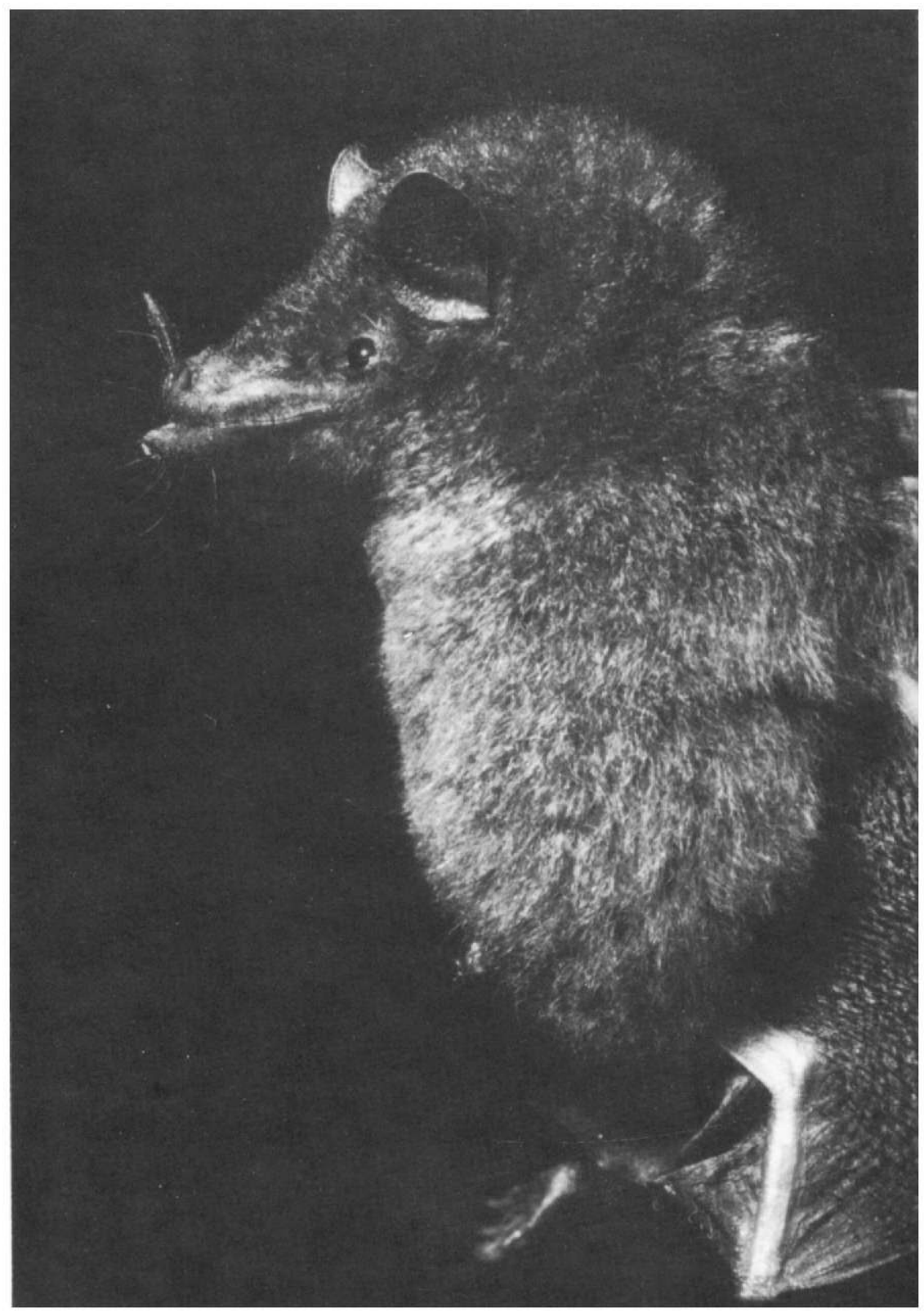

Fig. 43. Underwood's long-tongued bat, Hylonycteris underwoodi. Photo by B. L. Clauson. 


\section{Lonchophylla robusta \\ Panama Long-tongued Bat}

Panama long-tongued bats occur from Nicaragua to Peru (Fig. 44). This monotypic species normally is found in forested habitats, but it also occurs in agricultural areas. They are known to roost in caves in colonies that can be fairly sizable (Handley 1966). Food items include pollen, nectar, fruit, and insects (Gardner 1977). Nothing is known of the reproductive cycle, although we collected a pregnant female in April in Braulio Carrillo.

The first Costa Rican specimens were collected by J. DeAbate in 1956 (Walton 1963). The first specimens from the Caribbean lowland were reported by Armstrong (1969) from Los Diamantes near Guápiles. LaVal and Fitch (1977) reported 12 from La Selva. We located a roost under a jumble of huge boulders along a stream near the 700-m campsite in Parque Nacional Braulio Carrillo. All our specimens were captured in mist nets set across the stream just above the roost, except for a single individual netted in the forest near $1,000 \mathrm{~m}$.

Bat flies collected from Lonchophylla robusta include Anastrebla nycteridis (5 males, 4 females), Eldunnia breviceps (1 male), and Trichobius lonchophyllae (6 males, 4 females).

Specimens examined (16) $-7.3 \mathrm{mi}$ SE of Puerto Viejo [ 2 males, 2 females, TTU]; $1 \mathrm{~km} \mathrm{~S}, 11.5 \mathrm{~km}$ E of San Miguel, $680 \mathrm{~m}$ [3 males, 4 females. USNM; 1 male, 3 females, UNA]; $3.5 \mathrm{~km} \mathrm{~S}, 11.5 \mathrm{~km}$ E of San Miguel, $1,000 \mathrm{~m}$ [1 male, USNM].

Additional records-Finca La Selva, $3 \mathrm{~km} \mathrm{~S}$ of Puerto Viejo [MSB].

\section{Subfamily Carollinae \\ Carollia brevicauda Silky Short-tailed Bat}

Silky short-tailed bats are distributed from San Luis Potosí, Mexico, to southeastern Brazil (Fig. 45). Carollia brevicauda is a monotypic species.

This bat is much more common in second growth and disturbed habitats than in primary forest. Roosts are known from caves, tunnels, hoilow trees, and culverts (Pine 1972). A variety of fruits and some insects are consumed by these bats (Gardner 1977). They exhibit the bimodal polyestrous reproductive pattern common to many phyllostomids (Wilson 1979).

This species was hidden in the synonymy of $C$. perspicillata until the work of Pine (1972). It frequently has been confused with that species and, in many areas especially at higher elevations, actually may be much more common than C. perspicillata. This is the case at La Selva, where LaVal and Fitch (1977) captured 461. In Parque Nacional Braulio Carrillo, it is reasonably common in disturbed habitats up to about $700 \mathrm{~m}$ in elevation. Ectoparasites we collected from $C$. brevicauda include two species of streblid bat flies. Speiseria ambigua ( 1 female) and Trichobius joblingi (1 female). 
Fig. 44. Panama longtongued bat, Lonchophylla robusta. Photo by B. L. Clauson.
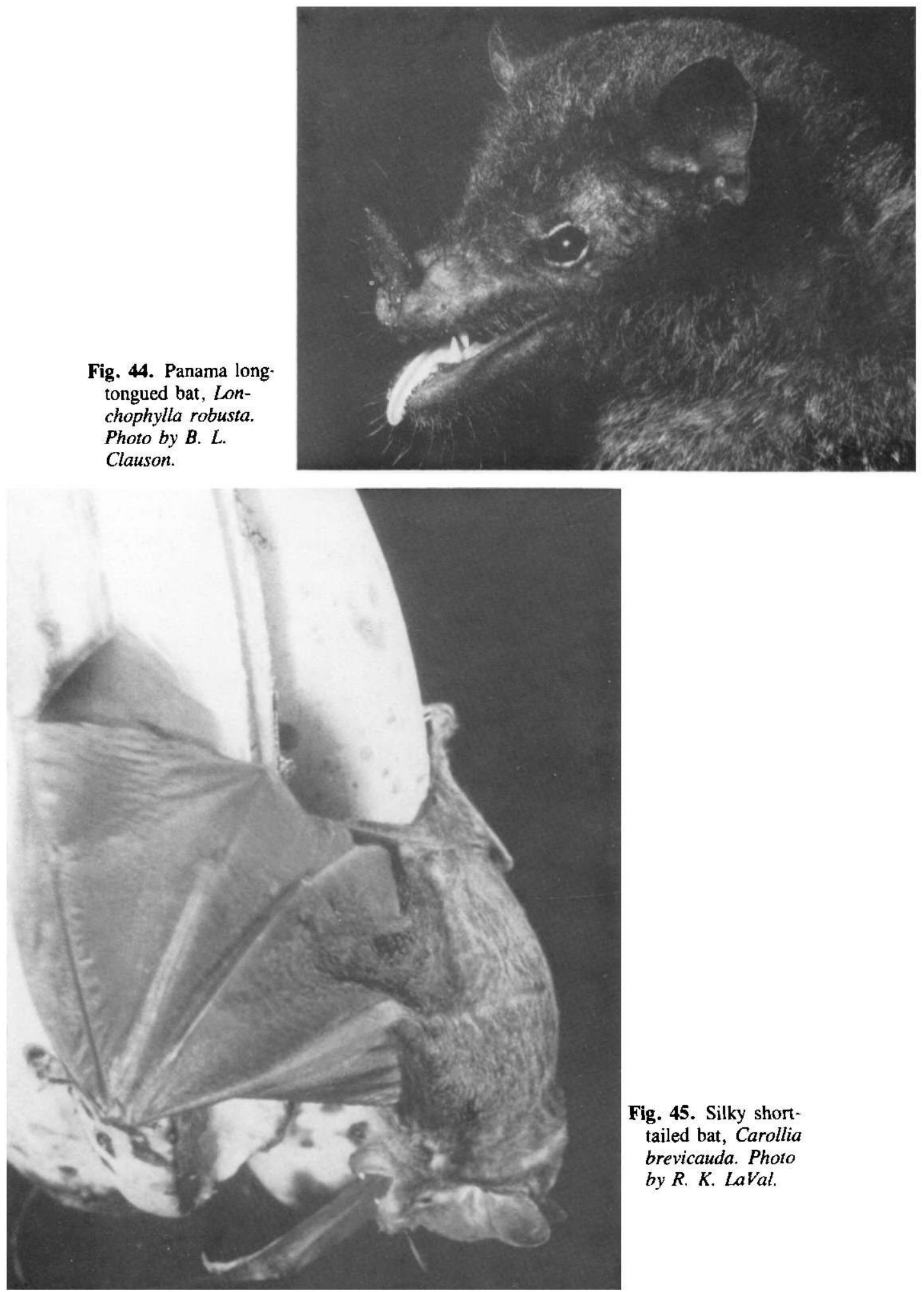

Fig. 45. Silky shorttailed bat, Carollia brevicauda. Photo by $R$. K. LaVal. 
Specimens examined (31)-2.5 km SE of Puerto Viejo [2 males, CM; 1 male, TCWC]; Finca La Selva, $3 \mathrm{~km} \mathrm{~S}$ of Puerto Viejo, $70 \mathrm{~m}[10$ males, 8 females, $\mathrm{KU} ; 1$ male, MSB]; $7.3 \mathrm{mi}$ SE of Puerto Viejo [1 male, TTU]; $11 \mathrm{~km} \mathrm{~S}, 4.5 \mathrm{~km}$ W of Puerto Viejo, $270 \mathrm{~m}$ [1 female, USNM]; $1 \mathrm{~km} \mathrm{S,} 11.5 \mathrm{~km}$ E of San Miguel, $680 \mathrm{~m}$ [4 males, 2 females, USNM; 1 female, UNA].

Additional records (3) $-4 \mathrm{mi} \mathrm{W}$ of Puerto Viejo, $300 \mathrm{ft}$ [ 2 females, TCWC]; $5.5 \mathrm{mi} \mathrm{S}, 1 \mathrm{mi}$ E of Puerto Viejo, $400 \mathrm{ft}$ [1 female, TCWC].

\section{Carollia castanea \\ Allen's Short-tailed Bat}

Allen's short-tailed bats are found from Honduras to Bolivia (Fig. 46). Carollia castanea is a monotypic species.

These bats are more likely to be taken in primary forest than their congeners, but also are common in second growth habitats. Roosting sites include caves, tunnels, hollow trees, and under overhanging roots along stream banks (Pine 1972). They feed on a variety of fruits, and perhaps occasional insects (Gardner 1977). The reproductive cycle is bimodally polyestrous (Wilson 1979).

This species is common throughout lowland Costa Rica. LaVal and Fitch (1977) captured 302 at La Selva. We found it only at the $300-\mathrm{m}$ site in Braulio Carrillo, where we captured specimens in nets set over a stream, and along a trail in hillside primary forest.

Specimens examined (41)-Puerto Viejo, Río Sarapiquí, $300 \mathrm{ft}$ [1 female, FMNH; 3 males, 5 females, KU; 3 males, 2 females, UMMZ]; $2.5 \mathrm{~km}$ SE of Puerto Viejo [2 males, 1 female, CM; 2 males, TCWC]; Finca La Selva, $3 \mathrm{~km}$ $\mathrm{S}$ of Puerto Viejo, $70 \mathrm{~m}$ [1 male, 4 females, KU; 1 male, 5 females, LACM; 2 females, 1 sex ?, MSB]; $7.3 \mathrm{mi}$ SE of Puerto Viejo [2 females, TTU]; $11 \mathrm{~km}$ $\mathrm{S}, 4.5 \mathrm{~km}$ W of Puerto Viejo, $270 \mathrm{~m}$ [4 males, 1 female, USNM; 1 male, UNA]. Additional records (3)-5.5 mi S, $1 \mathrm{mi}$ E of Puerto Viejo, ca. $400 \mathrm{ft} \mathrm{[3} \mathrm{males,}$ TCWC].

\section{Carollia perspicillata Seba's Short-tailed Bat}

Seba's short-tailed bats are distributed from Puebla, Mexico, to Argentina (Fig. 47). The Costa Rican subspecies, Carollia perspicillata azteca, is found throughout Central America.

This is one of the most widespread and abundant species of Neotropical bats. It is particularly common in second growth and disturbed habitats. Roosts are known from caves, tunnels, hollow trees, buildings, culverts, and under large leaves (Pine 1972). These bats specialize on fruits of the genus Piper, but take a wide variety of other fruits, and also insects during some seasons (Gardner 1977). The reproductive pattern is the familiar one of bimodal polyestry (Wilson 1979). Fleming (1983a, 1988) summarized the results of more than 10 years of detailed studies of the life history of this species in Costa Rica. 
Fig. 46. Allen's short-tailed bat, Carollia castanea.

Photo by B. L. Clauson.
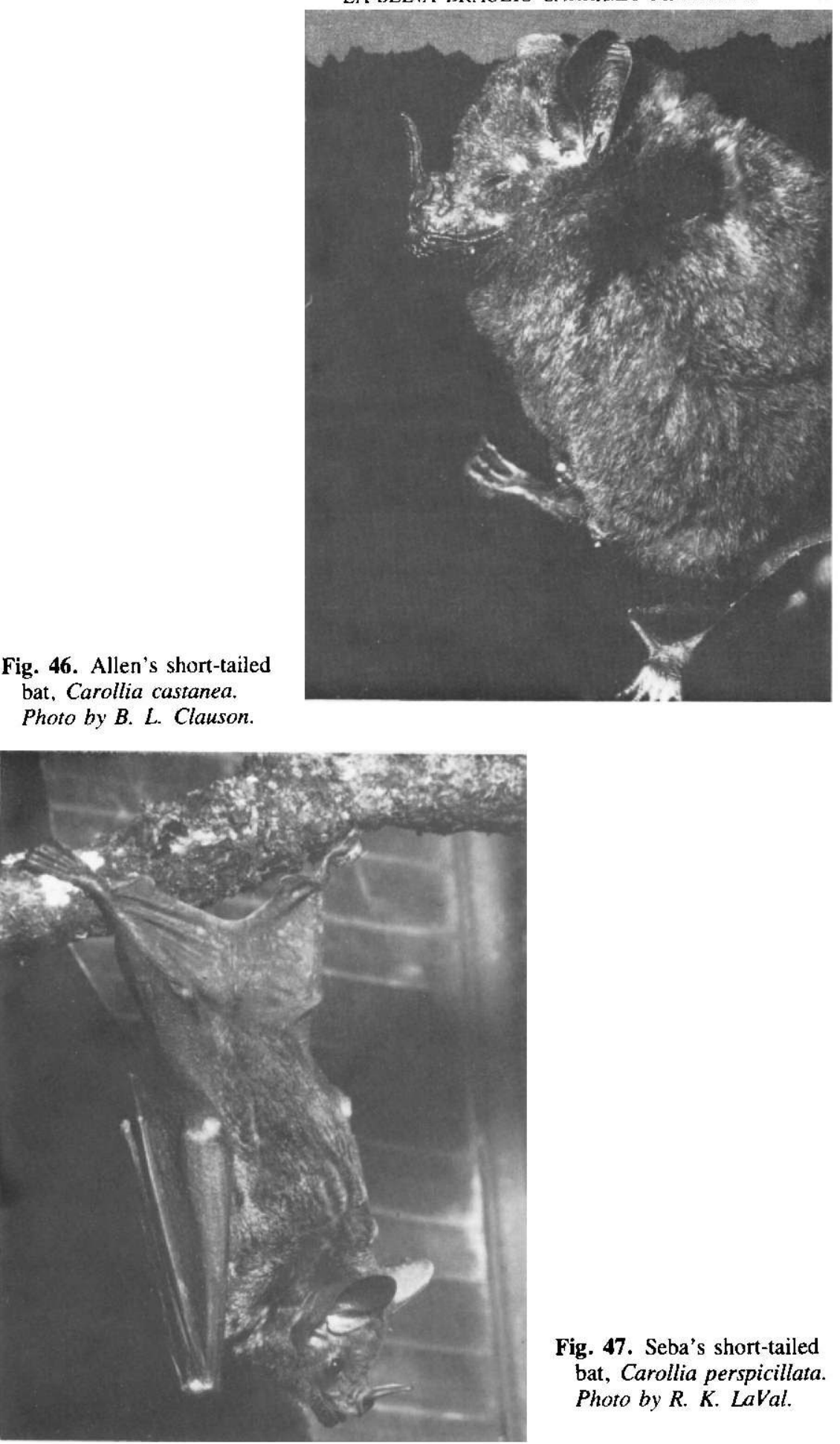

Fig. 47. Seba's short-tailed bat, Carollia perspicillata. Photo by R. K. LaVal. 
This species is common in the lowlands throughout Costa Rica. LaVal and Fitch (1977) captured 101 at La Selva, and we have found them to be abundant there on many occasions since 1968 . We found them to be common in second growth habitats up to $700 \mathrm{~m}$ in Parque Nacional Braulio Carrillo. An adult female collected at Puerto Viejo on 14 July 1961 carried a single embryo, $18 \mathrm{~mm}$ crownrump length.

We collected two species of streblid bat flies, Speiseria ambigua (1 female) and Trichobius joblingi (1 female), from $C$. perspicillata. The biology of three species of bat flies of the family Streblidae, which are host-specific, blood-feeding ectoparasites on C. perspicillata, was investigated at La Selva by Fritz (1983). He found that the life cycles of the bat flies are tightly synchronized with the life cycles of their hosts.

Specimens examined (43)-Puerto Viejo, Río Sarapiquí, 100 m [10 males. 3 females, KU; 5 males, 4 females, UMMZ]; $2.5 \mathrm{~km} \mathrm{SE}$ of Puerto Viejo 2 males, 1 female, CM]; Finca La Selva, $3 \mathrm{~km} \mathrm{~S}$ of Puerto Viejo, $70 \mathrm{~m}$ [1 male, KU; 1 female, LACM; 2 males, MSB]; $11 \mathrm{~km} \mathrm{S,} 4.5 \mathrm{~km} \mathrm{~W}$ of Puerto Viejo, $270 \mathrm{~m}$ [ 6 males, 2 females, USNM]; $1 \mathrm{~km} \mathrm{S,} 11.5 \mathrm{~km}$ E of San Miguel. $680 \mathrm{~m}$ [1 male, 1 female, USNM; 2 males, 2 females, UNA].

Additional records (10)-1.5 mi S of Cariblanco [2 males, 1 sex ?, MVZ]; $4 \mathrm{mi} \mathrm{W}$ of Puerto Viejo, $300 \mathrm{ft}$ [ 3 females, TCWC]; $5.5 \mathrm{mi} \mathrm{S}, 1 \mathrm{mi} \mathrm{E}$ of Puerto Viejo, $400 \mathrm{ft}$ [4 males, TCWC].

\section{Subfamily Stenoderminae \\ Artibeus jamaicensis Jamaican Fruit-eating Bat}

Jamaican fruit-eating bats are found from Sinaloa and Tamaulipas, Mexico, south through northern South America to Brazil and Paraguay (Fig. 48). Two subspecies are known from Costa Rica, Artibeus jamaicensis paulus from Guanacaste Province, and $A$. j. richardsoni from the rest of the country. Although widespread and abundant, species limits and infraspecific variation within this complex of bats are not well understood.

This is one of the most common species of bats throughout tropical America. It is found in most habitat types except perhaps the highest and driest. The known roosting habits are also catholic: caves, tunnels, hollow trees, logs, culverts, bridges, foliage, leaf-tents, and under tree roots (Foster and Timm 1976; Tuttle 1976). Gardner (1977) reported fruits as the primary food source, but flowers, leaves, and occasional insects also are taken. The reproductive cycle is one of bimodal polyestry (Wilson 1979). Morrison (1983) summarized natural history information.

The distribution in Costa Rica is widespread and well documented. This is one of the most common species of bat at La Selva. LaVal and Fitch (1977) captured 111 during their study, and we have captured numerous individuals during OTS field courses. They are found routinely in all habitats at La Selva. In Parque Nacional Braulio Carrillo, we found them to be common up to $700 \mathrm{~m}$. 


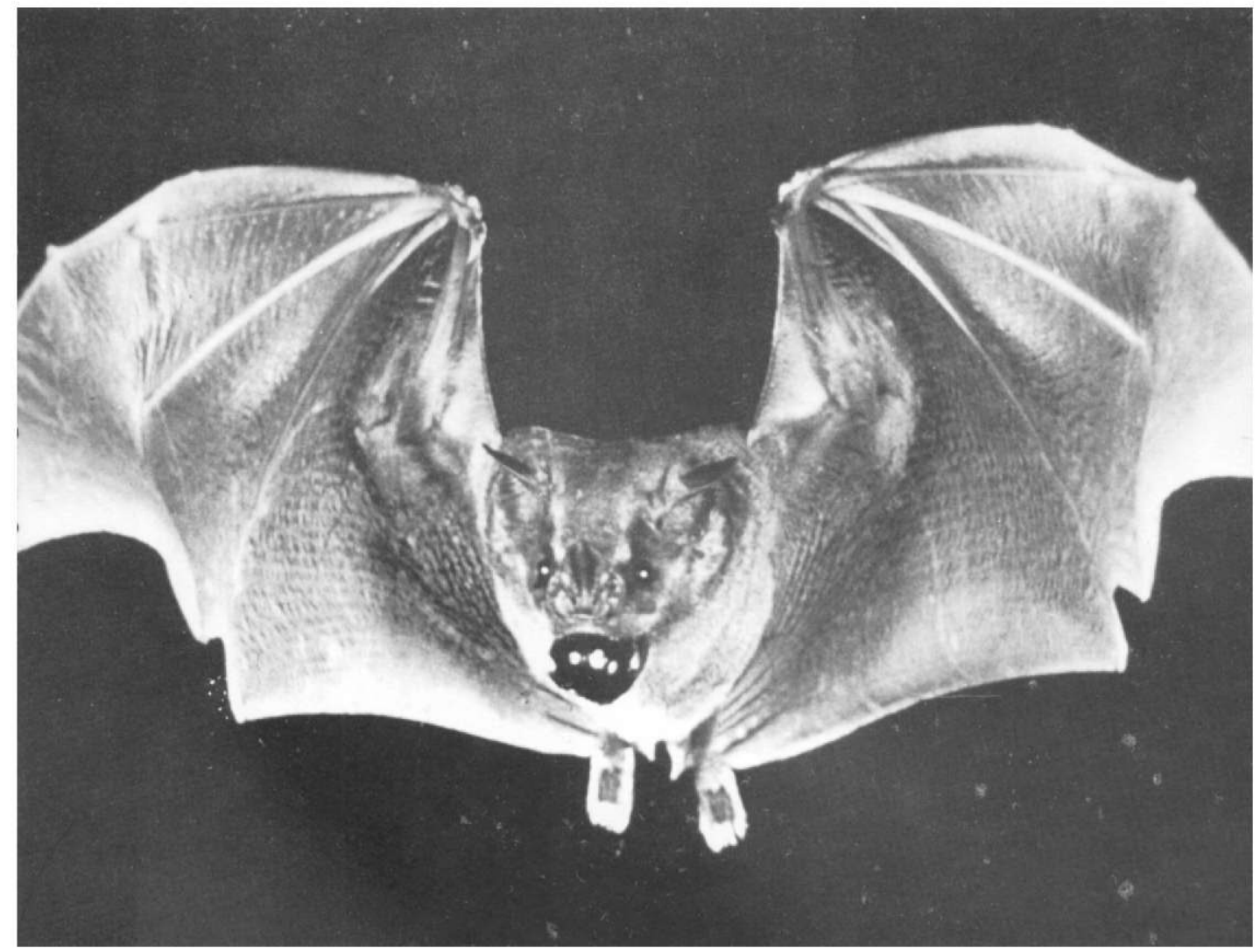

Fig. 48. Jamaican fruit-eating bat, Artibeus jamaicensis. Photo by M. D. Tuttle.

Specimens examined (22)-Finca La Selva, $3 \mathrm{~km} \mathrm{~S}$ of Puerto Viejo, $70 \mathrm{~m}$ [1 male, KU; 1 female, LACM]; Puerto Viejo, Río Sarapiquí, 300 ft [2 females, $\mathrm{KU} ; 7$ males, 3 females, UMMZ]; $11 \mathrm{~km} \mathrm{S,} 4.5 \mathrm{~km}$ W of Puerto Viejo, $270 \mathrm{~m}$ [ 3 males, 2 females, USNM; 1 female, UNA]; $1 \mathrm{~km} \mathrm{S.} 11.5 \mathrm{~km}$ E of San Miguel, $680 \mathrm{~m}$ [2 females, USNM].

Additional records (6) -6 mi SSE of Puerto Viejo [ 3 males, 1 female, TCWC]; $3 \mathrm{mi} \mathrm{N}$ of Heredia, 5,600 ft [2 males, TCWC]. 


\section{Artibeus lituratus \\ Big Fruit-eating Bat}

Big fruit-eating bats are found from Sinaloa, Mexico, south through Central America to Argentina in South America (Fig. 49). According to Davis (1984), the single subspecies occurring in Costa Rica is Artibeus lituratus palmarum. He recognized $A$. intermedius, formerly considered a subspecies of $A$. lituratus, as a distinct species. Artibeus intermedius is more common on the Pacific side of the country.

This species is widespread and locally abundant. The variety of habitats used ranges from dry forest to wet tropical forest. Roosting sites include caves, tunnels, hollow trees, buildings, culverts, foliage, and rock crevices (Goodwin and Greenhall 1961). Although primarily frugivorous, flowers, leaves, and insects also are taken (Gardner 1977). The reproductive cycle is one of bimodal polyestry (Wilson 1979; Willig 1985).

Although found throughout the country, this larger species is less abundant at most sites than $A$. jamaicensis. LaVal and Fitch (1977) took 16 at La Selva. We collected only one from Braulio Carrillo. Frequently, these bats forage higher in the canopy than do $A$. jamaicensis, and are more difficult to capture in groundlevel mist nets.

Specimens examined (7)-Finca La Selva, $3 \mathrm{~km} \mathrm{~S}$ of Puerto Viejo, $70 \mathrm{~m}$ [1 male, 2 females, LACM; 1 male, 1 sex ?, MSB]; $11 \mathrm{~km} \mathrm{S,} 4.5 \mathrm{~km} \mathrm{~W}$ of Puerto Viejo, 270 m [1 male, UNA]; Puerto Viejo, Río Sarapiquí, 300 ft [1 female, KU].

Fig. 49. Big fruit-eating bat, Artibeus lituratus. Photo by B. L. Clauson.

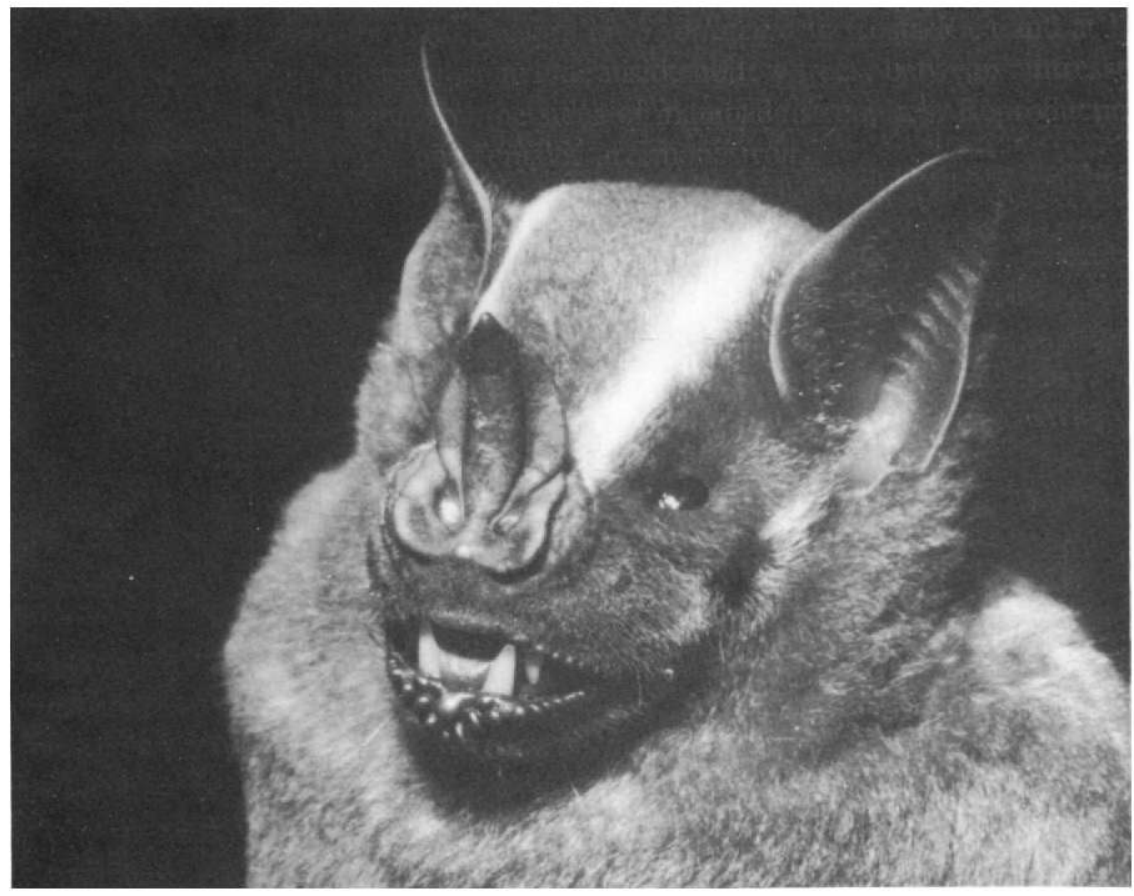




\section{Chiroderma salvini Salvin's White-lined Bat}

Salvin's white-lined bats are found from Chihuahua, Mexico, south through Central America to Peru and Bolivia (Fig. 50). Only the nominate subspecies, Chiroderma salvini salvini, is known to occur in Costa Rica, although Hall's (1981) distribution map suggests that $C$. s. scopaeum may be found in Guanacaste.

This species is found in forested regions, usually at middle or high elevations. They are frugivorous, but details of the food habits are lacking. The reproductive pattern is likely bimodal polyestry (Wilson 1979). Roosting sites are unknown.

Dobson (1878) described $C$. salvini from a specimen collected in Costa Rica by $O$. Salvin. White-lined bats are also known from near San Vito de Java (Wilson 1983a). Our specimen from $680 \mathrm{~m}$ in Parque Nacional Braulio Carrillo is the first record for the northeastern Caribbean slopes. It was a pregnant female, netted over a small stream crossing a pasture area.

Specimen examined (1)-1 km S, $11.5 \mathrm{~km} \mathrm{E}$ of San Miguel, $680 \mathrm{~m}[1$ female, USNM].

Fig. 50. Salvin's white-lined bat, Chiroderma salvini. Photo by R. K. LaVal. 


\section{Chiroderma villosum Shaggy-haired Bat}

Shaggy-haired bats are found from Veracruz, Mexico, to Brazil (Fig. 51). The Central American subspecies is Chiroderma villosum jesupi, the nominate race being restricted to South America and Trinidad.

This species is normally found in primary tropical forests at lower elevations. Roosting sites are unknown. Although presumed to be frugivorous, nothing is known of this bat's food habits. The species is polyestrous, but details of the cycle are unknown.

Goodwin (1946) first reported this species from Costa Rica based on a specimen from Guanacaste. Armstrong (1969) took the first specimen from La Selva, and LaVal and Fitch (1977) added a second.

Specimens examined (6)-Puerto Viejo, Río Sarapiquí, 100 m [1 male, KU; 1 male, 1 female, UMMZ]; Finca La Selva, $3 \mathrm{~km} \mathrm{~S}$ of Puerto Viejo, $70 \mathrm{~m}$ [1 male, 2 females, LACM].

Fig. 51. Shaggy-haired bat, Chiroderma villosum. Photo by B. L. Clauson.

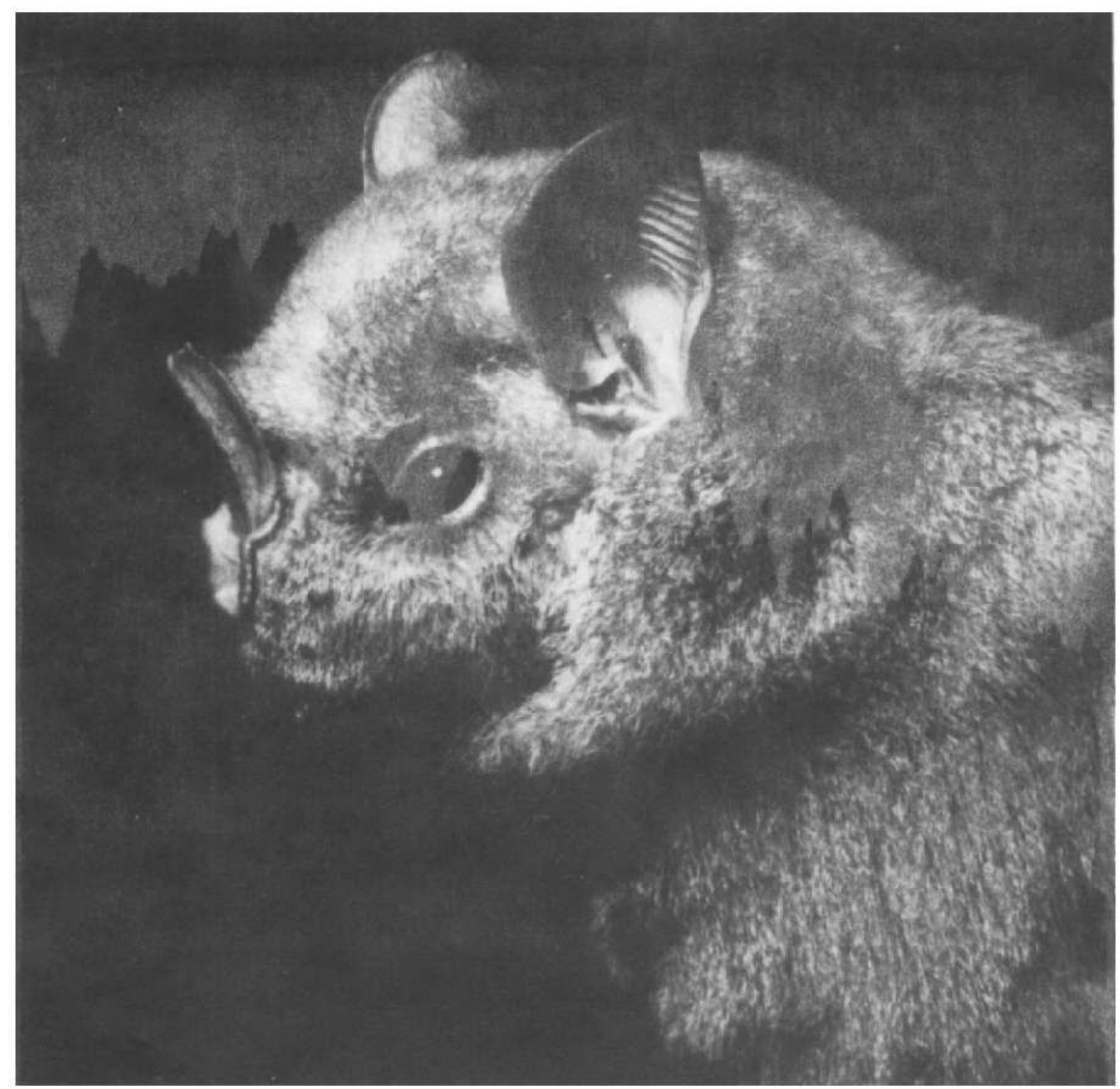




\section{Dermanura azteca Highland Fruit-eating Bat}

Highland fruit-eating bats are known from Sinaloa, Mexico, to western Panama (Fig. 52). The Costa Rican subspecies is Dermanura azteca major, which is essentially restricted to Costa Rica and northern Panama. We follow Owen (1987) in recognizing Dermanura as a genus distinct from Artibeus.

This species is limited to habitats above $1,000 \mathrm{~m}$. Known roosting sites are caves and tunnels (Davis et al. 1964), although it seems likely that this bat also will prove to be a tent-constructor as have all the other previously studied small Dermanura (Timm 1987). Food habits are unknown, but the bat is presumed to be frugivorous. Reproductive data are too few to allow speculation on the annual pattern (Wilson 1979). Biology of this species was summarized by Webster and Jones (1982a).

This species had not been recorded previously from the northeastern Caribbean slope of Costa Rica, although it is known from the Talamancas and the Monteverde area (Wilson 1983a). Our specimen from near Vara Blanca was taken from a pasture near a small stream.

Specimens examined (9)-5 km E of Vara Blanca, 2,050 m [ 1 male, USNM]; $1 \mathrm{mi} \mathrm{W}$ of Vara Blanca [2 males, 6 females, TTU].

Additional records (4)-Vara Blanca [2 females, TCWC; 2, LSUMZ].

Fig. 52. Highland fruit-eating bat, Dermanura azteca. Photo by R. K. LaVal.

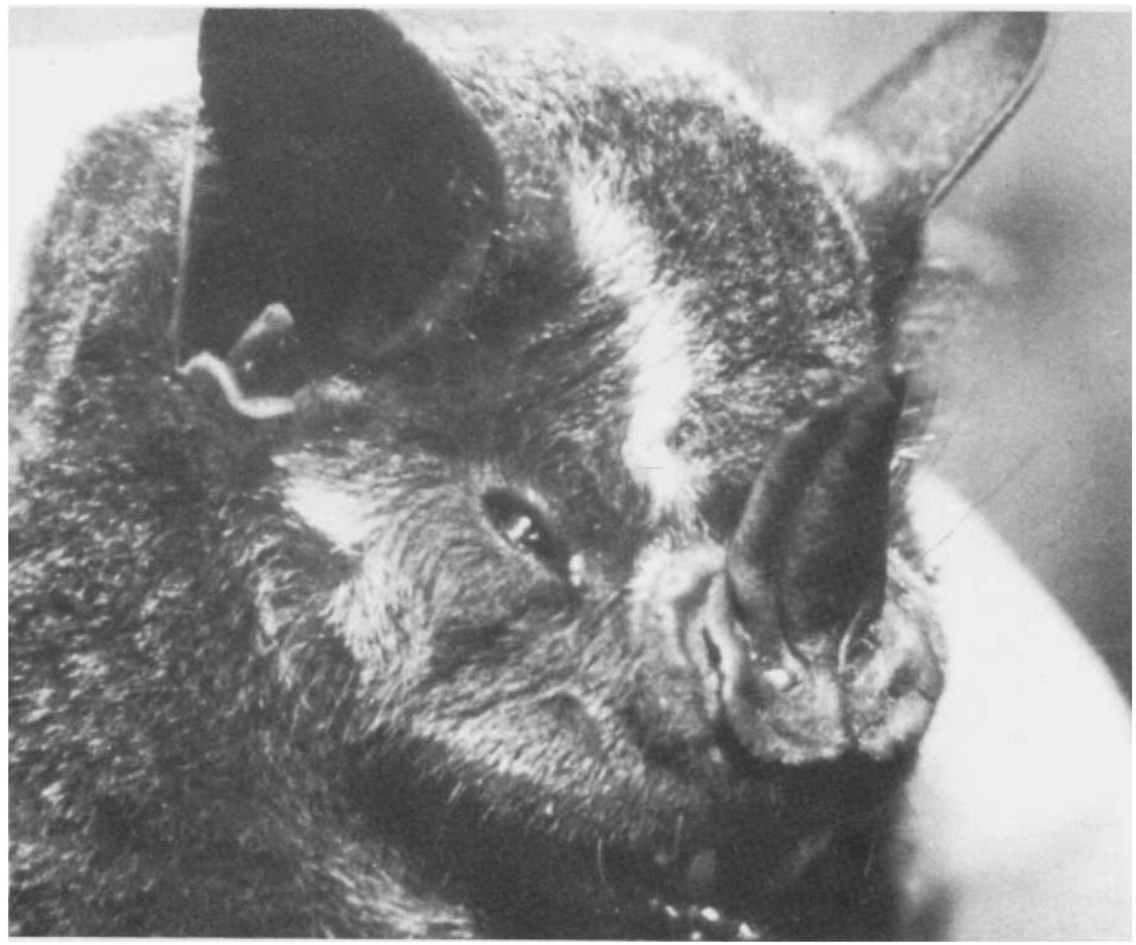




\section{Dermanura hartii \\ Little Fruit-eating Bat}

Little fruit-eating bats are known from Jalisco and Tamaulipas, Mexico, to Bolivia (Fig. 53). Dermanura hartii is a monotypic species exhibiting little geographic variation throughout its extensive range. The generic placement, however, has been the subject of much debate. This species has been considered to be the sole member of the genus Enchisthenes, a member of the overly inclusive genus Artibeus, and most recently a member of the genus Dermanura (Owen 1987).

This species occurs primarily in highlands, although there are scattered records from the lowlands. It occurs in a variety of types of forests ranging from dry to quite humid (Handley 1976). Roosting sites have not been reported. Gardner (1977) summarized the feeding habits and suggested figs were an important component of the diet. The few data available on reproduction suggest a bimodal pattern (Wilson 1979).

Armstrong (1969) reported the first record for Costa Rica from Finca Las Cruces in Puntarenas Province. Gardner et al. (1970) listed 19 additional specimens from the country, including the first from Heredia Province.

Specimens examined (5)-Vara Blanca, 1,900 m [1 male, 4 females, LSUMZ].

\section{Dermanura phaeotis Pygmy Fruit-eating Bat}

Pygmy fruit-eating bats are found from Sinaloa and Veracruz, Mexico, south throughout Central America and much of northern South America to Peru (Fig. 54). Two subspecies are known from Costa Rica, the nominate form from the Caribbean versant, and Dermanura phaeotis palatina from northwestern Costa Rica. This is an abundant species in Costa Rica and at La Selva, although probably not as abundant there and in many other areas as is $D$. watsoni. These two species are similar in appearance and are often misidentified, both in the field and in museum collections.

Pygmy fruit-eating bats are found in lowland forested areas, both wet and dry (Timm 1985). They modify both banana and Heliconia leaves to form tents for roosting sites (Timm 1987). Primarily frugivorous, they occasionally take pollen as well, and have been reported to feed on 11 different species of plants in Costa Rica (Heithaus et al. 1975). The reproductive pattern is one of bimodal polyestry (Timm 1985).

Although Dermanura phaeotis are common in Costa Rica, specimens have been confused under a variety of names in the past. LaVal and Fitch (1977) reported that this was one of the most common species of bats they captured at La Selva. We caught only two individuals in Parque Nacional Braulio Carrillo.

Specimens examined (9)-Finca La Selva, $3 \mathrm{~km} \mathrm{~S}$ of Puerto Viejo, $70 \mathrm{~m}$ [2 males, 2 females, KU; 2 males, 1 female, MSB]; $11 \mathrm{~km} \mathrm{S,} 4.5 \mathrm{~km} \mathrm{~W}$ of Puerto Viejo, $270 \mathrm{~m}$ [1 male, UNA]; $1 \mathrm{~km} \mathrm{~S}, 11.5 \mathrm{~km}$ E of San Miguel, $680 \mathrm{~m}$ [1 male, USNM]. 
Fig. 53. Little fruiteating bat, Dermanura hartii. Photo by R. K. LaVal.

Fig. 54. Pygmy fruiteating bat, Dermanura phaeotis. Photo by R. M.

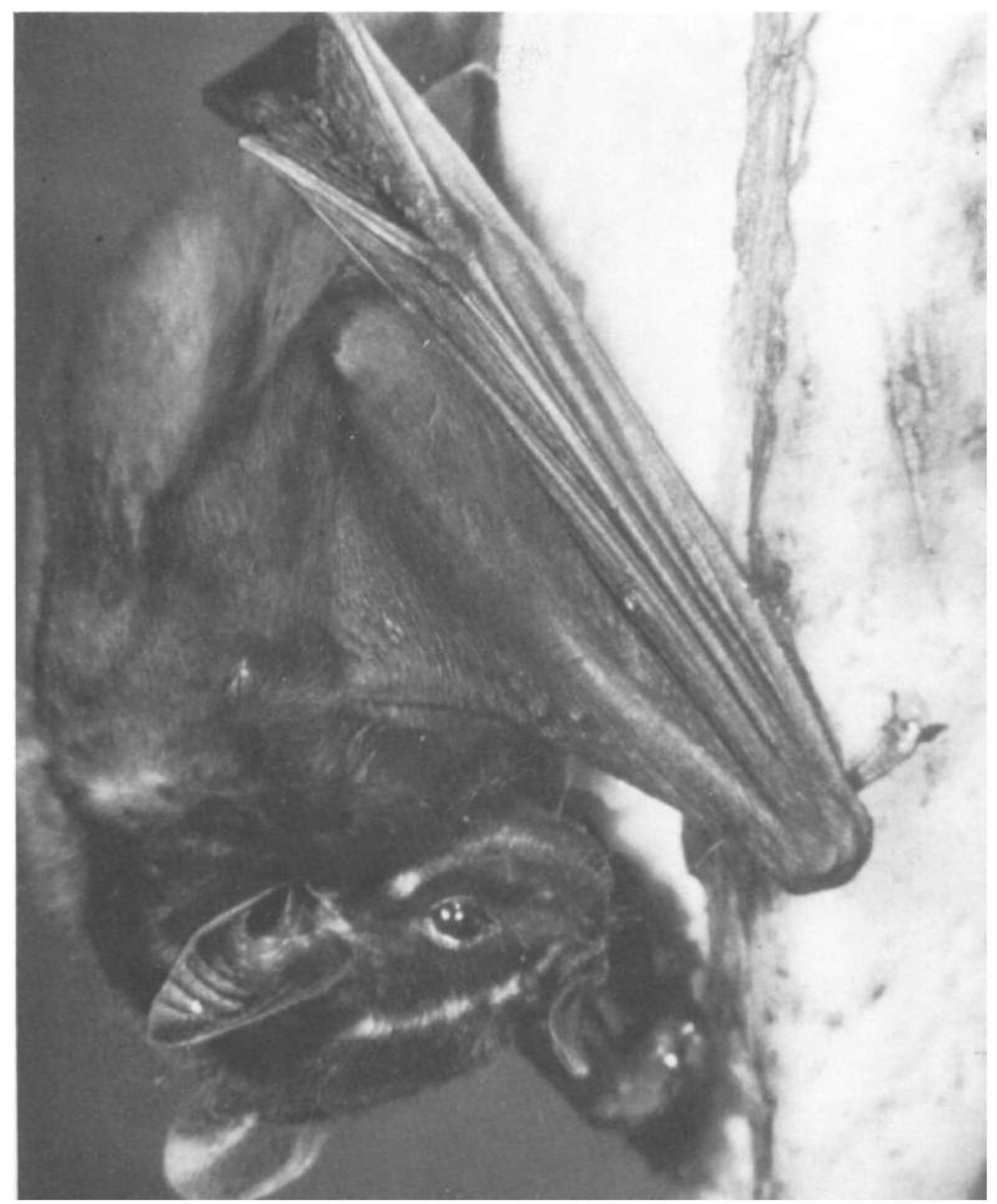
Timm.

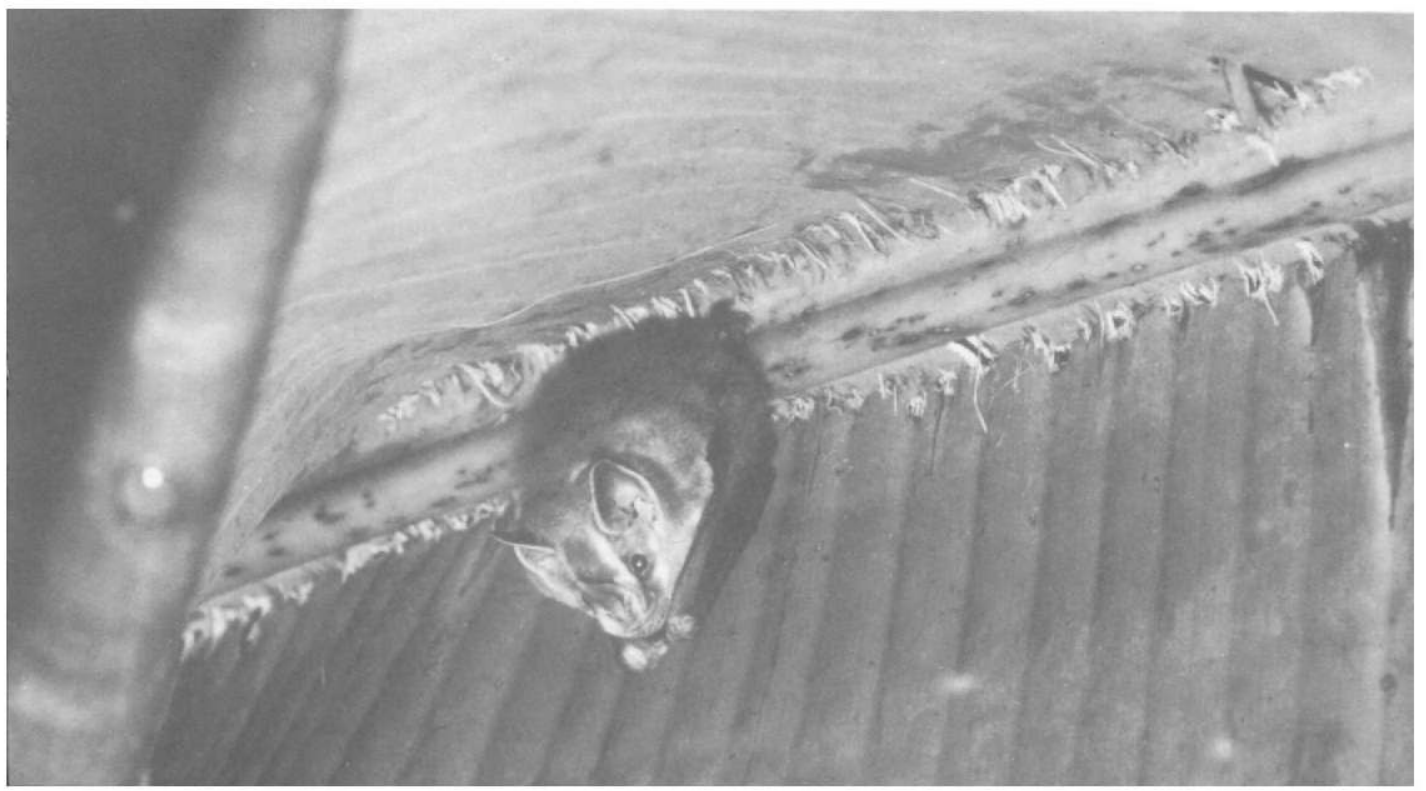




\section{Dermanura tolteca Lowland Fruit-eating Bat}

Lowland fruit-eating bats are found from Sinaloa, Mexico, to Panama (Fig. 55). Only the nominate subspecies, Dermanura tolteca tolteca, occurs in Costa Rica.

The common name is something of a misnomer, as these bats are more frequently caught at middle elevations than in the lowlands. A variety of forested habitats are inhabited, including dry forest. Known roosts include caves, tunnels, buildings, and foliage (Tuttle 1976). Dinerstein (1986) listed the fruit of 17 species of plants in the diet of this species at Monteverde, Costa Rica. Births are spread through much of the year in Mexico, and the usual bimodal polyestrous pattern was confirmed by Dinerstein (1986). Biology of this bat was summarized by Webster and Jones (1982b).

This species is abundant at Monteverde (LaVal and Fitch 1977), and is known from several other localities in Costa Rica (Wilson 1983a). Our specimens from Braulio Carrillo, taken in primary forest, represent the first records for the northeastern Caribbean slope. Two of the three females were pregnant.

Specimens examined (3) $-1 \mathrm{~km} \mathrm{S,} 11.5 \mathrm{~km}$ E of San Miguel, $680 \mathrm{~m}$ [2 females, USNM; 1 female, UNA].

Additional records-Vara Blanca [LSUMZ; Gardner et al. 1970].

\section{Dermanura watsoni Thomas' Fruit-eating Bat}

Thomas' fruit-eating bats are found from Oaxaca and Veracruz, Mexico, through Central America to Colombia (Fig. 56). The species is monotypic. Dermanura watsoni has been considered at times to be a subspecies of $D$. cinerea.

Although common in a variety of habitats, this species normally is restricted to forested areas. It seems to be absent from the drier parts of Costa Rica and of Central America in general. This is another species of tent-making bat, modifying large leaves to provide roosting sites (Timm 1987). They are primarily frugivorous (Gardner 1977). The reproductive pattern is bimodal polyestry (Fleming et al. 1972).

These bats are found throughout most of Costa Rica, but apparently do not occur in the Guanacaste lowlands. We collected two from Parque Nacional Braulio Carrillo, both from riparian situations near undisturbed forest.

One species of spinturnicid bat mite, Periglischrus iheringi, was collected on D. watsoni.

Specimens examined (47)-2.5 km SE of Puerto Viejo [3 males, CM; 1 male, TCWC]; Finca La Selva, $3 \mathrm{~km}$ S of Puerto Viejo, $70 \mathrm{~m}$ [1 male, FMNH; 5 males, 2 females, LACM; 8 males, 4 females, MSB]; Puerto Viejo, Río Sarapiquí, $300 \mathrm{ft}$ [ 2 males, 4 females, KU; 1 male, 4 females, UMMZ]; $7.3 \mathrm{mi} \mathrm{SE}$ of Puerto Viejo [7 males, TTU]; $11 \mathrm{~km} \mathrm{~S}, 4.5 \mathrm{~km} \mathrm{~W}$ of Puerto Viejo, $270 \mathrm{~m}$ [1 female, USNM]; Río Puerto Viejo [1 male, 1 female, KU]; $1 \mathrm{~km} \mathrm{~S}, 11.5 \mathrm{~km}$ E of San Miguel. $680 \mathrm{~m}$ [1 male, USNM; 1 male, UNA]. 


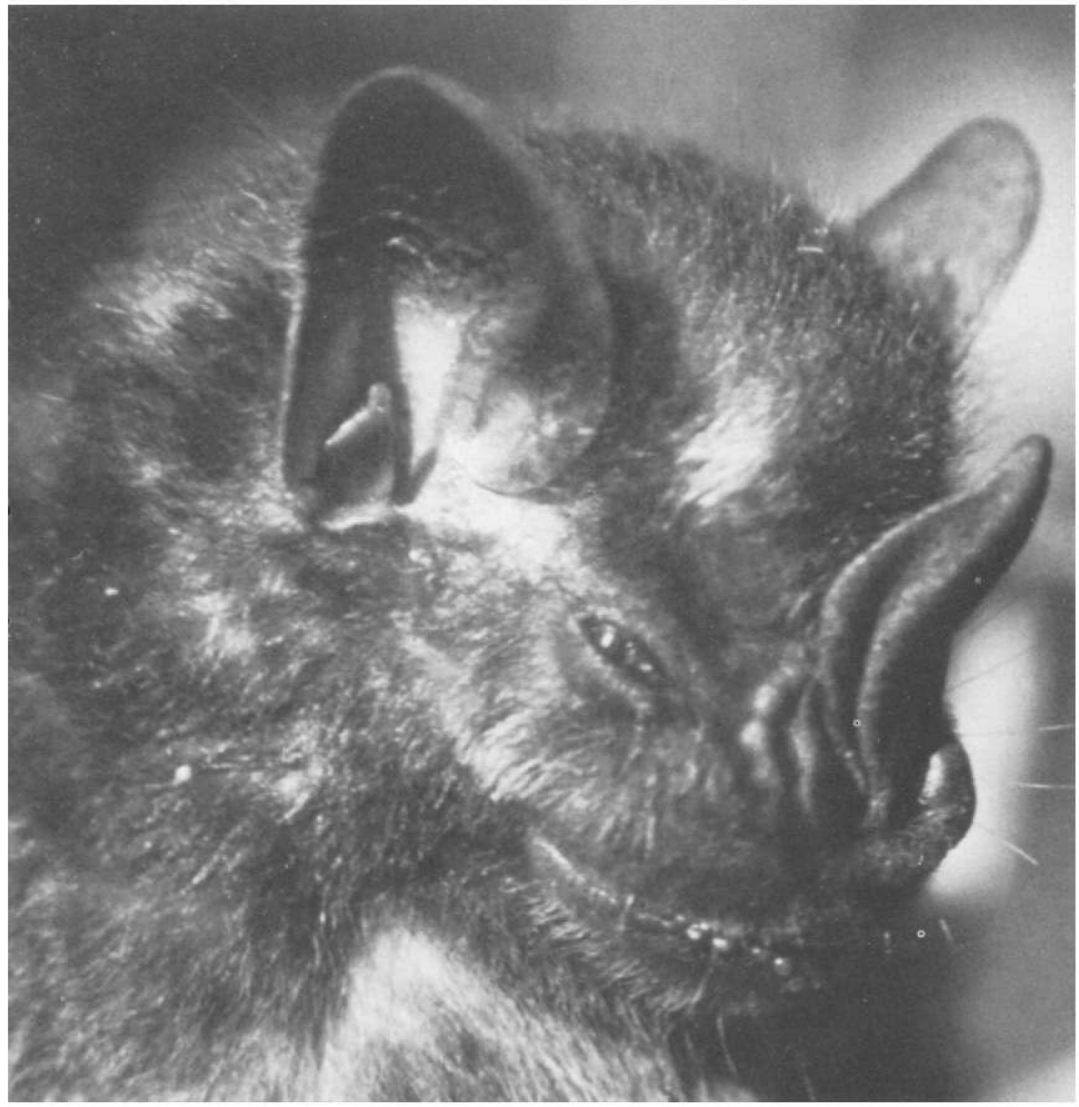

Fig. 55. Lowland fruit-eating bat, Dermanura tolteca. Photo by $R . K$. LaVal.

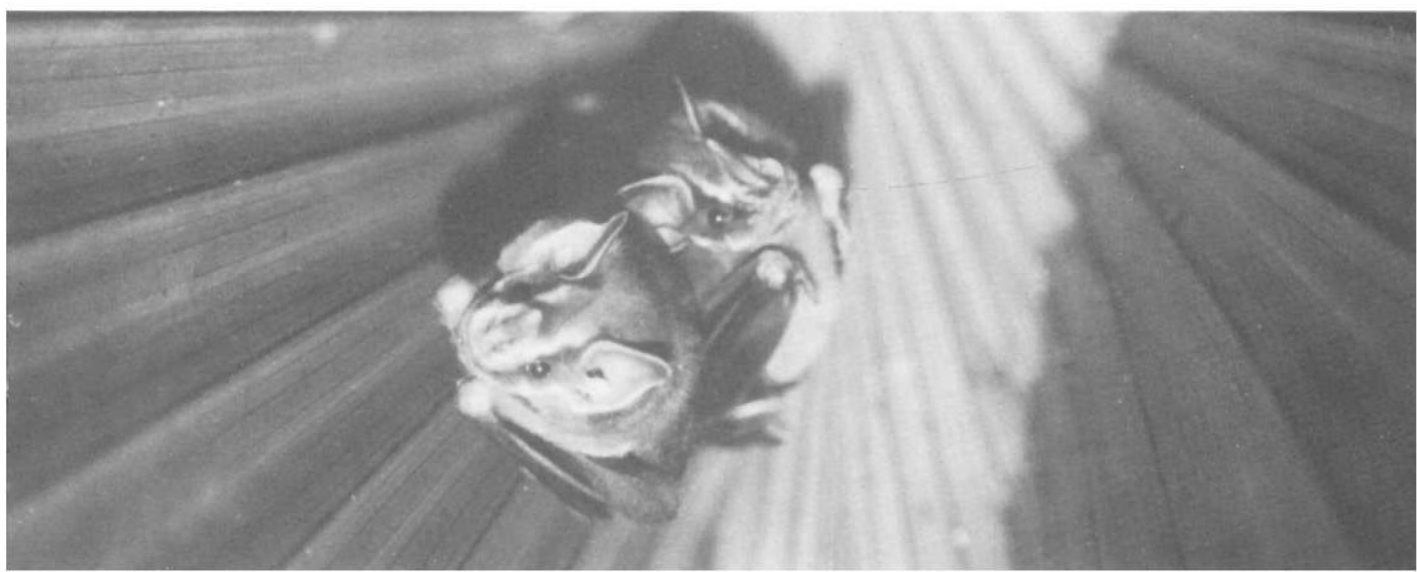

Fig. 56. Thomas' fruit-eating bat, Dermanura watsoni. Photo by B. L. Clauson. 


\section{Ectophylla alba \\ Caribbean White Bat}

Caribbean white bats occur only from Honduras to Panama (Fig. 57). Ectophylla alba is a monotypic species.

White bats are limited to the Caribbean lowlands of Central America, where they occur in primary and old second-growth forests interspersed with Heliconia (Timm 1982). Ectophylla is one of the most distinctively colored bats; it is bright white with darker wings and bright orange-yellow ears and nose leaf. It is one of the few species of bats that actively alters the shape of leaves to create diurnal roosting sites. Ectophylla severs the side nerves and interconnected tissues on both Heliconia and Calathea from near the base to near the tip of the leaf causing the sides of the leaf to droop (Brooke 1987b; Timm 1982; Timm and Mortimer 1976). The roosting bats hang from the midrib of the leaf and are protected from predators and weather by their roosting structure, which has been termed a "tent." Brooke (1987b) reported that occupied tents typically contained four to eight roosting bats and that some tents were used only as night feeding roosts and others only as diurnal roosts. She found the birth of young to be highly synchronous, occurring in the latter half of April. Ectophylla alba is frugivorous; Brooke found fruit pulp and seeds from the small understory fig, Ficus columbrinae, under noctural feeding roosts. Several additional aspects of the biology of $E$. alba have been investigated at La Selva (Brooke 1987b; Greenbaum et al. 1975; LaVal and Fitch 1977; Timm 1982). The species is now known from a total of 12 localities, but only those at La Selva and the adjoining Braulio Carrillo and at Parque Nacional Tortuguero are in reserves where there is assurance that their habitat will be protected.

Fig. 57. Caribbean white bat, Ectophylla alba. Photo by B. L. Clauson.

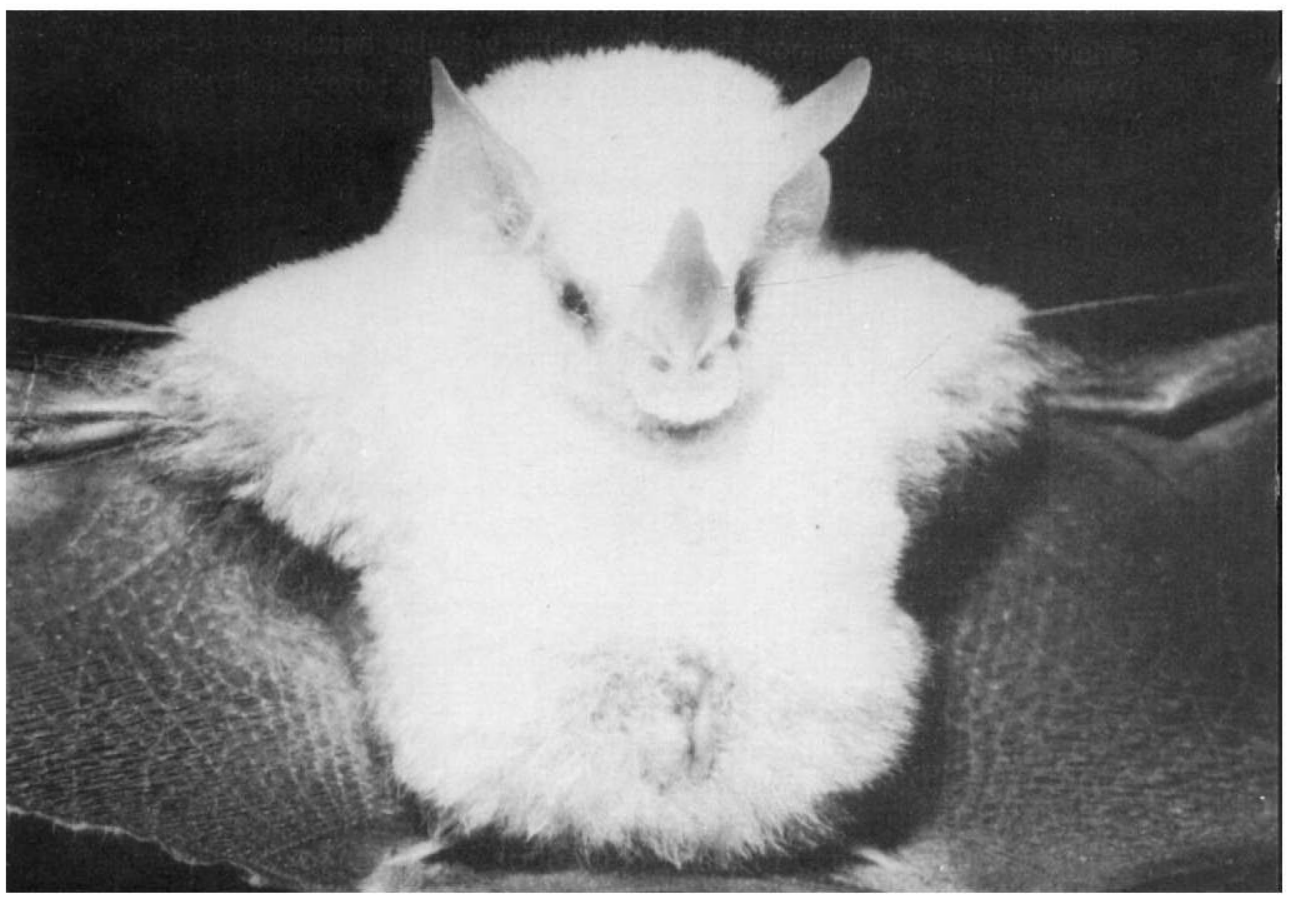


Allen (1892) described the species based on a specimen he thought was from Honduras, but which actually was from Nicaragua. Later (1898) he described a subsequent specimen he thought was from Nicaragua, but which turned out to be from Costa Rica. Casebeer et al. (1963) finally collected three specimens unequivocally from La Selva. We have since observed them there regularly, and LaVal and Fitch (1977) reported capturing 38. Our specimens from Parque Nacional Braulio Carrillo were taken over a small stream in primary forest. One of the two females captured on 9 February 1983 was pregnant, carrying an embryo $7 \mathrm{~mm}$ in length.

Specimens examined (17)-Puerto Viejo, $100 \mathrm{~m}$ [1 female, KU]; $2.5 \mathrm{~km} \mathrm{SE}$ of Puerto Viejo [1 female, CM]; Finca La Selva, $3 \mathrm{~km} \mathrm{~S}$ of Puerto Viejo, $70 \mathrm{~m}$ [ 2 females, KU; 4 females, LACM; 5 males, MSB; 1 male, UMMZ; 1 female, USNM]; $11 \mathrm{~km} \mathrm{~S}, 4.5 \mathrm{~km}$ W of Puerto Viejo, $270 \mathrm{~m}$ [1 female, UNA; 1 female, USNM].

\section{Sturnira lilium \\ Yellow-shouldered Bat}

Yellow-shouldered bats are known from Sonora and Tamaulipas, Mexico, to Argentina (Fig. 58). The Costa Rican subspecies, Stumira lilium parvidens, is found throughout Central America and Mexico.

An occupant of both dry and wet forests, this species is locally abundant throughout tropical lowlands. Roost sites include caves, tunnels, hollow trees, buildings, in culverts, and under bridges (Villa-R. 1967). Basically frugivorous, they also may feed occasionally on pollen or nectar (Gardner 1977). They are bimodally polyestrous in Costa Rica (Wilson 1979).

Mares and Wilson (1971) recorded 32 specimens from Guanacaste. Curiously, this species has never been taken at La Selva, although there is a single record from Puerto Viejo.

Specimen examined (1)-Puerto Viejo, Río Sarapiquí, $300 \mathrm{ft}$ [1 female, UMMZ].

Fig. 58. Yellow-shouldered bat, Sturnira lilium. Photo by B. L. Clauson.

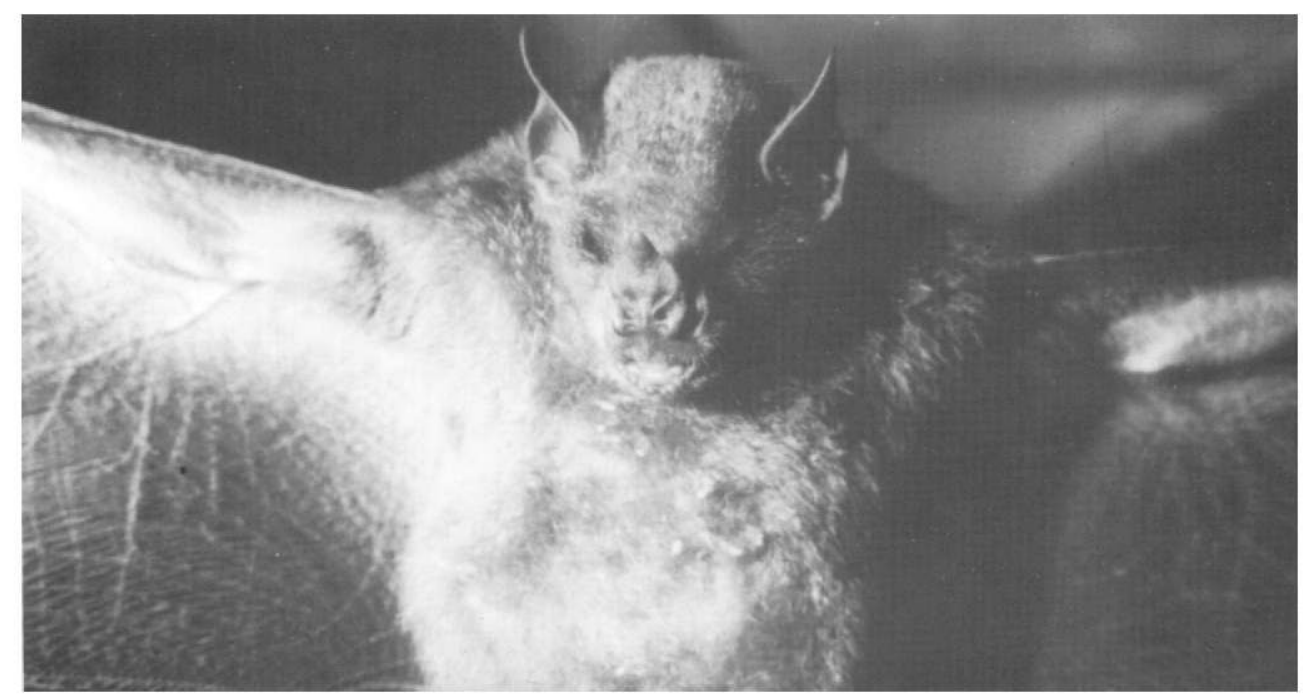




\section{Sturnira ludovici \\ Anthony's Bat}

Anthony's bats are widely distributed from Sinaloa and Tamaulipas, Mexico, to Peru and Bolivia (Fig. 59). The nominate subspecies, Sturnira ludovici ludovici, is found throughout Central America (de la Torre 1961). The systematic status of this species is not well understood; it is almost surely a composite as currently recognized in the literature. True $S$. ludovici probably are restricted to northern South America. The Central American bats under discussion here may prove to be a distinct species, for which the name S. hondurensis (Goodwin 1940) is available.

Although Anthony's bat inhabits a variety of forest types, it is frequently more common at intermediate elevations. Nothing is known about roosting sites. At Monteverde, Dinerstein (1986) found $S$. ludovici feeding on the fruits of 29 species of plants. The reproductive cycle is the familiar one of bimodal polyestry (Wilson 1979).

Goodwin (1946) reported two specimens from Agua Buena, Puntarenas Province. Starrett and de la Torre (1964) added one from Volcán Turrialba, Cartago Province. Mares and Wilson (1971) reported two from near San Vito de Java, Puntarenas Province. LaVal and Fitch (1977) caught one at La Selva. We found them to be fairly common at middle and higher elevations in Braulio Carrillo. Three, of the females we caught in April were pregnant.

Specimens examined (11)-Finca La Selva, $3 \mathrm{~km} \mathrm{~S}$ of Puerto Viejo, $70 \mathrm{~m}$ [1 male, KU]; $11 \mathrm{~km} \mathrm{S,} 4.5 \mathrm{~km} \mathrm{~W}$ of Puerto Viejo, $270 \mathrm{~m}$ [1 male, UNA]; $1 \mathrm{~km}$ $\mathrm{S}, 11.5 \mathrm{~km}$ E of San Miguel, $680 \mathrm{~m}$ [ 3 females, USNM; 2 males, 1 female, USNM]; $5 \mathrm{~km}$ E of Vara Blanca, 2,050 m [2 females, USNM]; $2 \mathrm{~km} \mathrm{~N}, 0.5 \mathrm{~km} \mathrm{E}$ of Sacramento, 2,600 m [1 female, FMNH].

Additional records (3) $-3 \mathrm{mi} \mathrm{N}$ of Heredia, 5,600 $\mathrm{ft}$ [ 3 females, TCWC].

\section{Sturnira luisi \\ Luis' Bat}

Previously confused with Stumira lilium, Luis' bat was recognized only recently as a distinct species (Davis 1980). The type locality for $S$. luisi is Cariblanco in Alajuela Province, Costa Rica, and it is now known to occur from Costa Rica to Peru.

Our specimens came from wet forest, and the distribution of the known specimens suggest this as the primary habitat. Nothing is known about the natural history of these bats due to their confusion with $S$. lilium. Presumably they are frugivorous like their congeners. None of our specimens evidenced any reproductive activity. Our specimens all came from over a small stream through pasture land in an otherwise primary forest zone. Paratypes are known from Limón Province, so finding them in the park is not surprising.

Specimens examined (4)-1 km S, $11.5 \mathrm{~km}$ E of San Miguel, $680 \mathrm{~m}$ [1 male, 2 females, USNM; 1 female, UNA]. 


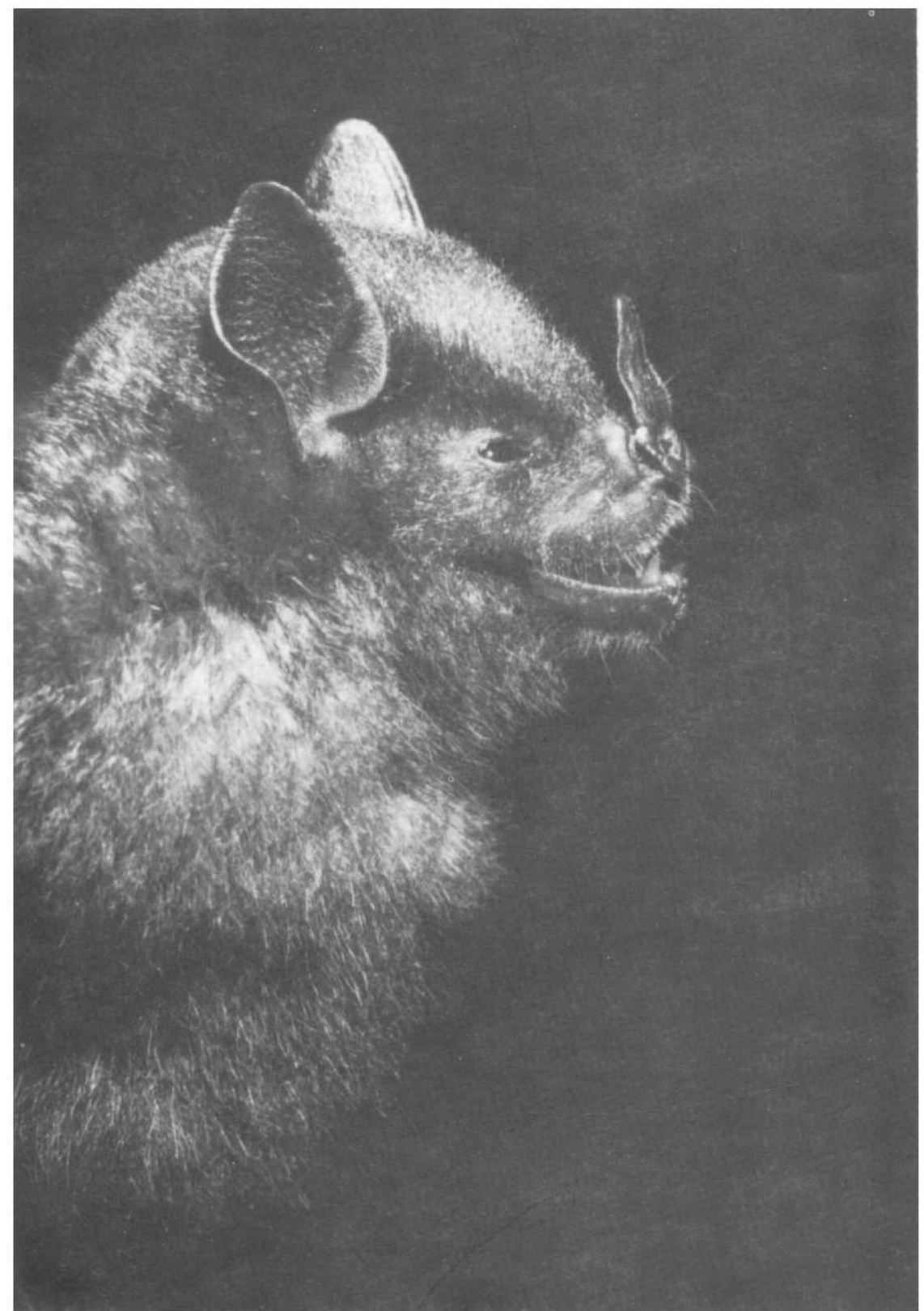

Fig. 59. Anthony's bat, Sturnira ludovici. Photo by B. L. Clauson. 


\section{Sturnira mordax Talamancan Bat}

Talanancan bats are endemic to the highlands of Costa Rica and adjacent western Panama (Fig. 60). The species is monotypic.

This is a middle to high elevation bat, found in both tropical and cloud forests. Roosting sites are unknown. They are frugivorous, and Howell and Burch (1974) reported the remains of four species of fruits in stomach contents. The reproductive cycle is polyestrous, probably bimodal based on the little data that are available and the fact that other species of Sturnira are bimodally polyestrous (Wilson 1979).

The type specimen was collected by C. Underwood at El Sauce Peralta, Costa Rica, in 1931. Davis et al. (1964) reported nine more from Cariblanco in Alajuela Province. Armstrong (1969) added a specimen from Finca Las Cruces near San Vito de Java, Puntarenas Province, and Gardner et al. (1970) added numerous specimens from several other localities. LaVal and Fitch (1977) found them at Monteverde. We found them to be common in Parque Nacional Braulio Carrillo from 700 to $2,000 \mathrm{~m}$. We caught them in primary forest and along pasture edges. Two females were pregnant in April. Gardner et al. (1970) reported that an adult female they captured on 2 May at Vara Blanca was lactating. We obtained two species of bat flies, both are undescribed species, from $S$. mordax: Megistopoda sp. (10 males, 5 females) and Trichobius sp. ( 2 males).

Specimens examined (16) $-1 \mathrm{~km} \mathrm{~S}, 11.5 \mathrm{~km}$ E of San Miguel, $680 \mathrm{~m}$ [2 males, 5 females, USNM]; $3.5 \mathrm{~km} \mathrm{~S}, 11.5 \mathrm{~km}$ E of San Miguel, 1,000 m [1 male, 3 females, USNM]; $9 \mathrm{~km} \mathrm{~S}, 11.5 \mathrm{~km}$ E of San Miguel, 1,520 m [1 male, USNM]; Vara Blanca [2 females, LSUMZ]; $5 \mathrm{~km}$ E of Vara Blanca, 2,050 m [1 male, 1 female, USNM].

\section{Uroderma bilobatum Tent-making Bat}

Tent-making bats are found from Oaxaca and Veracruz, Mexico, to Brazil (Fig. 61). Two subspecies occur in Costa Rica: Uroderma bilobatum molaris on the Caribbean versant and $U . b$. convexum on the Pacific side.

This species is found in a wide variety of habitats ranging from primary humid and dry forests to second-growth forest and pasture. As the name implies, roosts are constructed by modifying large leaves to form a tent. The diet is mainly fruit, although pollen, nectar, and insects occasionally are taken. The reproductive pattern is one of bimodal polyestry (Wilson 1979). The biology of tent-making bats was summarized by Baker and Clark (1987).

Mares and Wilson (1971) reported $U$. bilobatum from a variety of localities in Costa Rica, including La Selva. LaVal and Fitch (1977) captured 17 at La Selva and noted that pregnant females were observed in January and February.

Specimens examined (17)-Finca La Selva, $3 \mathrm{~km} \mathrm{~S}$ of Puerto Viejo, $70 \mathrm{~m}$ [1 male, FMNH; 2 males, LACM; 1 male, 1 female, MSB]; Puerto Viejo, Río Sarapiquí, $300 \mathrm{ft}$ [2 males, UMMZ]; $7.3 \mathrm{mi}$ SE of Puerto Viejo [1 female, TTU]; $8 \mathrm{mi}$ SE of Puerto Viejo [2 males, 7 females, TTU]. 
Fig. 60. Talamancan bat, Stumira mordax. Photo by $B$. L. Clauson.
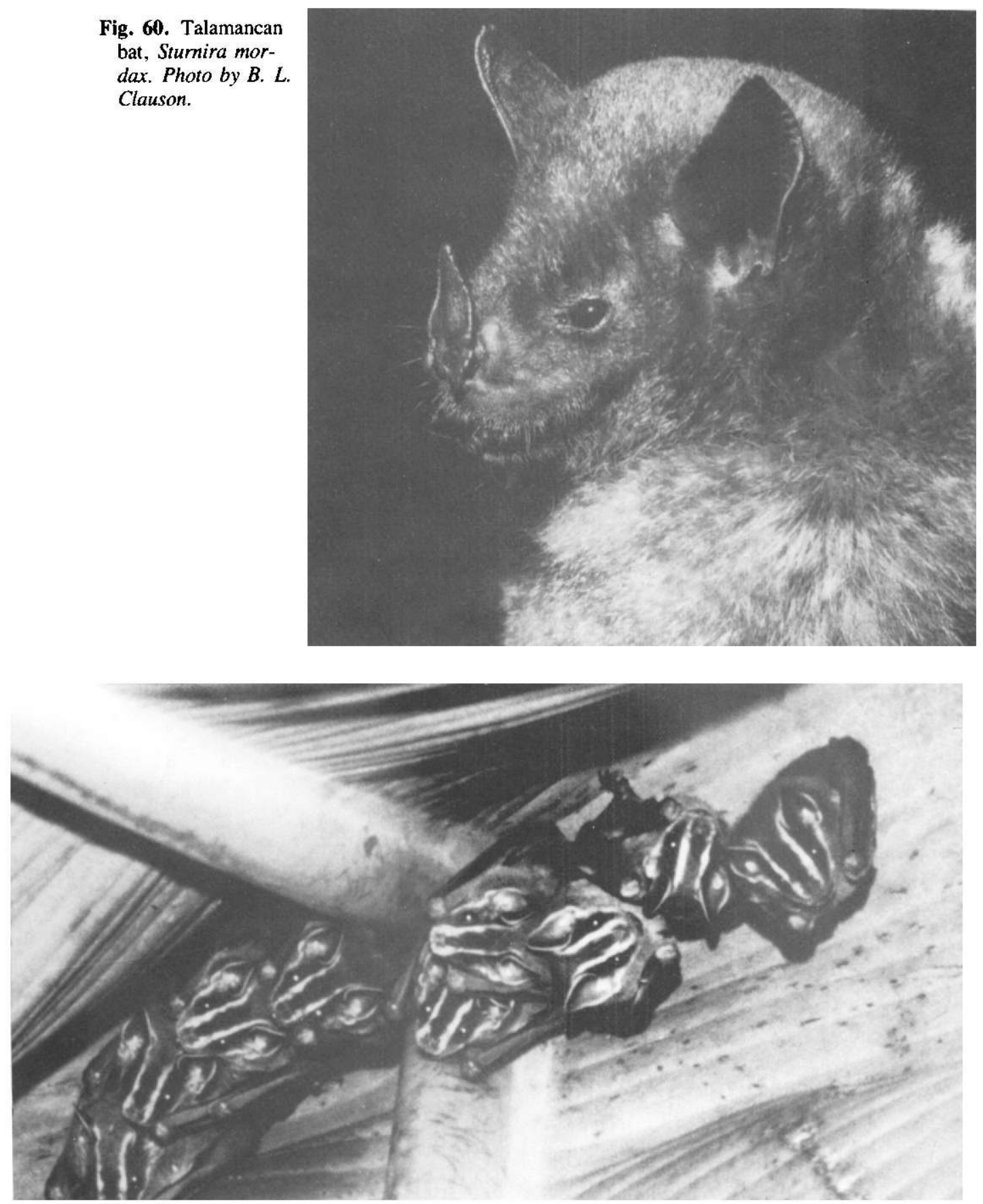

Fig. 61. Tent-making bats, Uroderma bilobatum. Photo by R. M. Timm. 


\section{Vampyressa nymphaea Big Yellow-eared Bat}

Big yellow-eared bats are found from Nicaragua through Costa Rica and Panama to Amazonian Brazil (Fig. 62). The species is monotypic.

This species is normally found in primary forest habitats. Although mainly frugivorous, some insect consumption has been reported (Fleming et al. 1972). The reproductive pattern is bimodal polyestry (Wilson 1979). Brooke (1987a), in a study of roosting ecology and social behavior of Vampyressa nymphaea at La Selva, found that these bats roosted exclusively under cut leaves of the understory shrub Pentagonia donnell-smithii (Rubiaceae). The bats severed the basal lateral nerves and the midrib near its midpoint to form a three-sided tent. One to three adult females roosted together with a single adult breeding male, suggesting a harem mating system. Pregnant females were found from early through mid-April. Tents were used for several days in succession, and there was some movement of individuals between tents. One tent was in use for more than 9 months, although not continuously (Brooke 1987a).

Gardner et al. (1970) reported the first $V$. nymphaea for Costa Rica from Cariari. Mares and Wilson (1971) reported additional specimens from Guanacaste and Puntarenas Provinces. LaVal and Fitch (1977) reported two from La Selva. Our specimen from Parque Nacional Braulio Carrillo was netted over a small stream with a closed canopy of riparian vegetation.

Specimens examined (3)-2.5 km SE of Puerto Viejo [1 male, CM]; Finca La Selva, $3 \mathrm{~km} \mathrm{~S}$ of Puerto Viejo, $70 \mathrm{~m}$ [1 male, FMNH]; $1 \mathrm{~km} \mathrm{~S}, 11.5 \mathrm{~km} \mathrm{E}$ of San Miguel, $580 \mathrm{~m}$ [1 male, USNM].

Fig. 62. Big yellow-eared bat, Vampyressa nymphaea. Photo by R. K. LaVal.

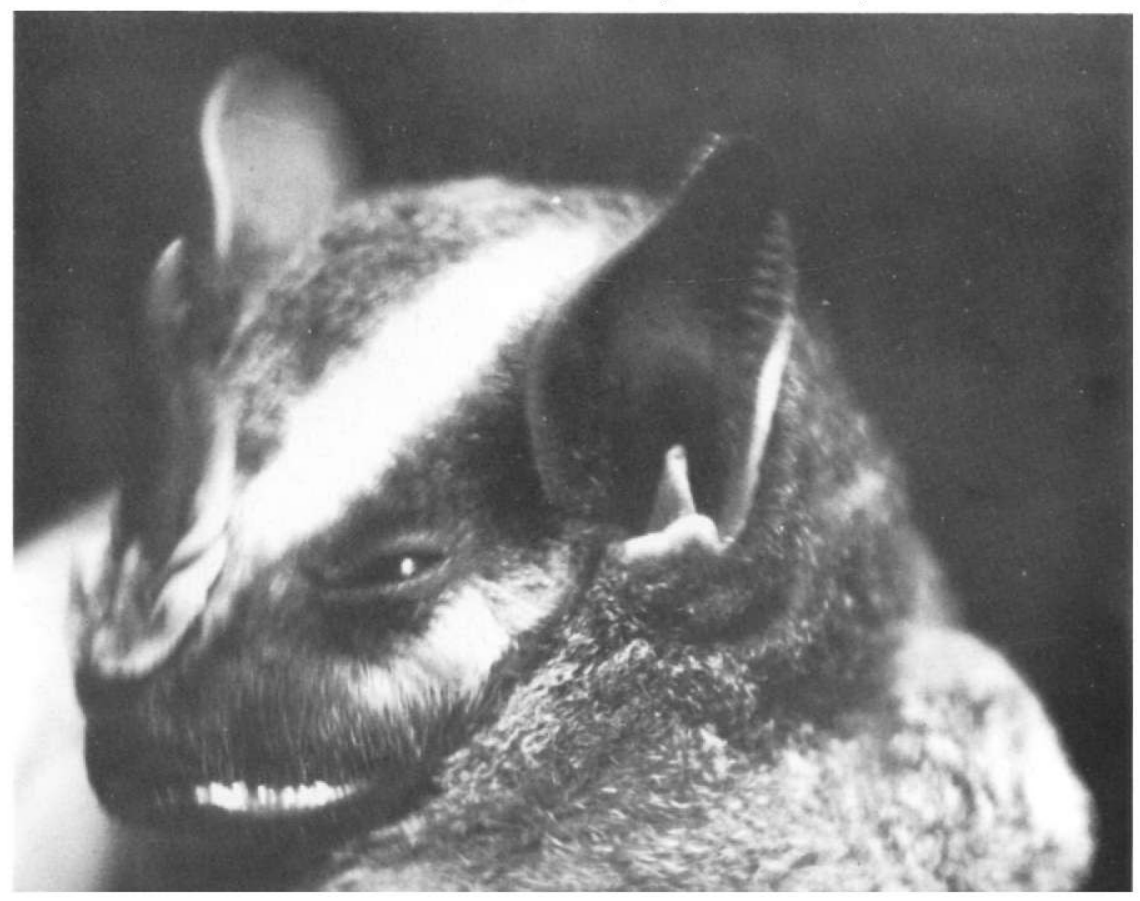




\section{Vampyressa pusilla \\ Little Yellow-eared Bat}

Little yellow-eared bats are found from Oaxaca and Veracruz, Mexico, to Brazil and Paraguay (Fig. 63). The Costa Rican subspecies, Vampyressa pusilla thyone, is found throughout Central America.

This species is found mainly in primary forest habitats, both wet and dry. Basically frugivorous, it has been reported to feed on Acnistes sp. in Costa Rica (Howell and Burch 1974). The reproductive cycle is the usual bimodal polyestry (Wilson 1979). Timm (1984) described the first known tent of little yellow-eared bats, which he found at La Selva. This species cuts the basal nerves of Philodendron leaves such that the sides of the leaf roll downward to form a pyramid-shaped tent. Brooke (1987b) found $128 \mathrm{~V}$. pusilla tents in Philodendron at La Selva over a several month period; seven of the tents were occupied, most by single bats. Biology of $V$. pusilla was summarized by Lewis and Wilson (1987).

Goodwin (1946) reported the first Costa Rican specimens from Agua Buena, Puntarenas Province. Armstrong (1969) reported on specimens from the Osa Peninsula, and on one collected in 1961 at La Selva. LaVal and Fitch (1977) captured 27 at La Selva and noted that pregnant females were seen in February, April, July, August, and September. A flightless juvenile was collected at La Selva on 17 July 1974.

Specimens examined (7)-Cariblanco [ 1 female, KU]; Finca La Selva, $3 \mathrm{~km}$ $\mathrm{S}$ of Puerto Viejo, $70 \mathrm{~m}$ [1 male, FMNH; 1 male, 1 female, KU; 2 males, 1 sex ?, MSB].

Additional record (1)-1.5 mi S of Cariblanco [1 male, MVZ].

Fig. 63. Little yellow-eared bat, Vampyressa pusilla. Photo by R. K. LaVal.

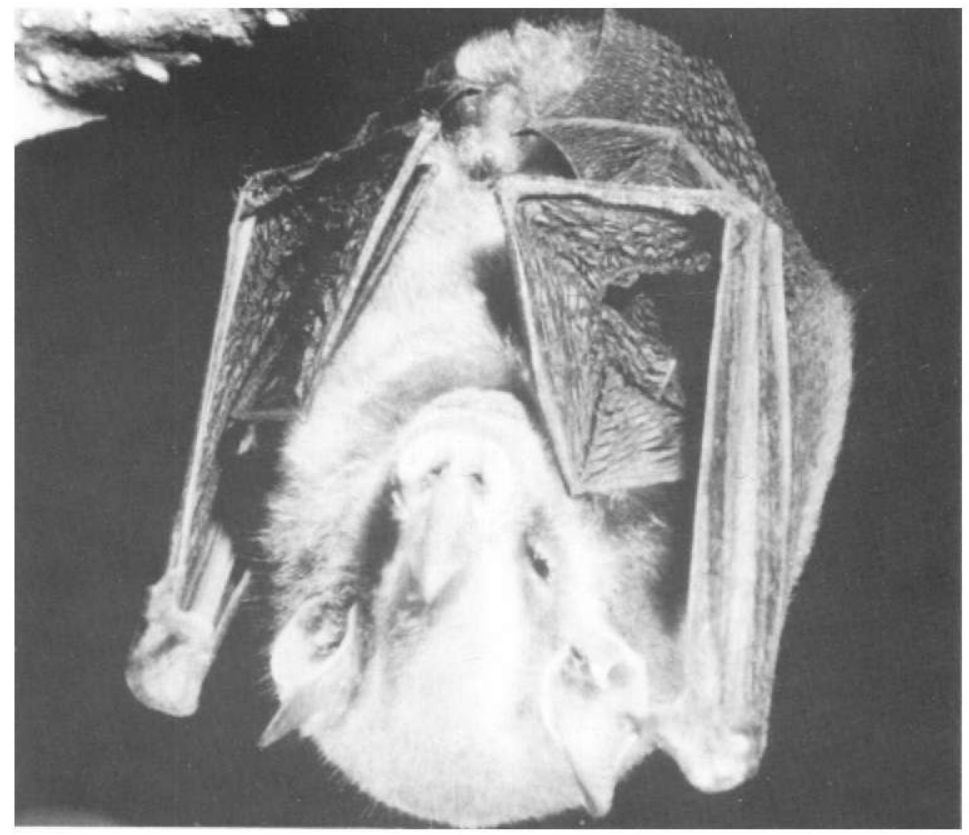




\section{Vampyrodes caraccioli \\ San Pablo Bat}

San Pablo bats are known from Oaxaca and southern Veracruz, Mexico, to Brazil and Bolivia (Fig. 64). The Costa Rican subspecies, Vampyrodes caraccioli major, is considered by some to be a species ( $V$. major) distinct from the South American $\boldsymbol{V}$, caraccioli.

This species is found predominately in primary forest habitats and is more common in low to middle elevation wet forests. The bats roost in small groups in foliage (Tuttle 1976). The diet is restricted to fruit (Gardner 1977). The reproductive pattern is bimodal polyestry (Wilson 1979).

The first specimen from Costa Rica was reported by Goldman (1920) from Alajuela Province. Starrett and Casebeer (1968) added several more from various localities. LaVal and Fitch (1977) took a single pregnant female from La Selva in February.

Specimens examined (22)-Puerto Viejo, $100 \mathrm{~m}$ [1 male, KU]; Finca La Selva, $3 \mathrm{~km} \mathrm{~S}$ of Puerto Viejo, $70 \mathrm{~m}$ [1 sex ?, MSB]; $7.3 \mathrm{mi} \mathrm{SE}$ of Puerto Viejo [11 males, 9 females, TTU].

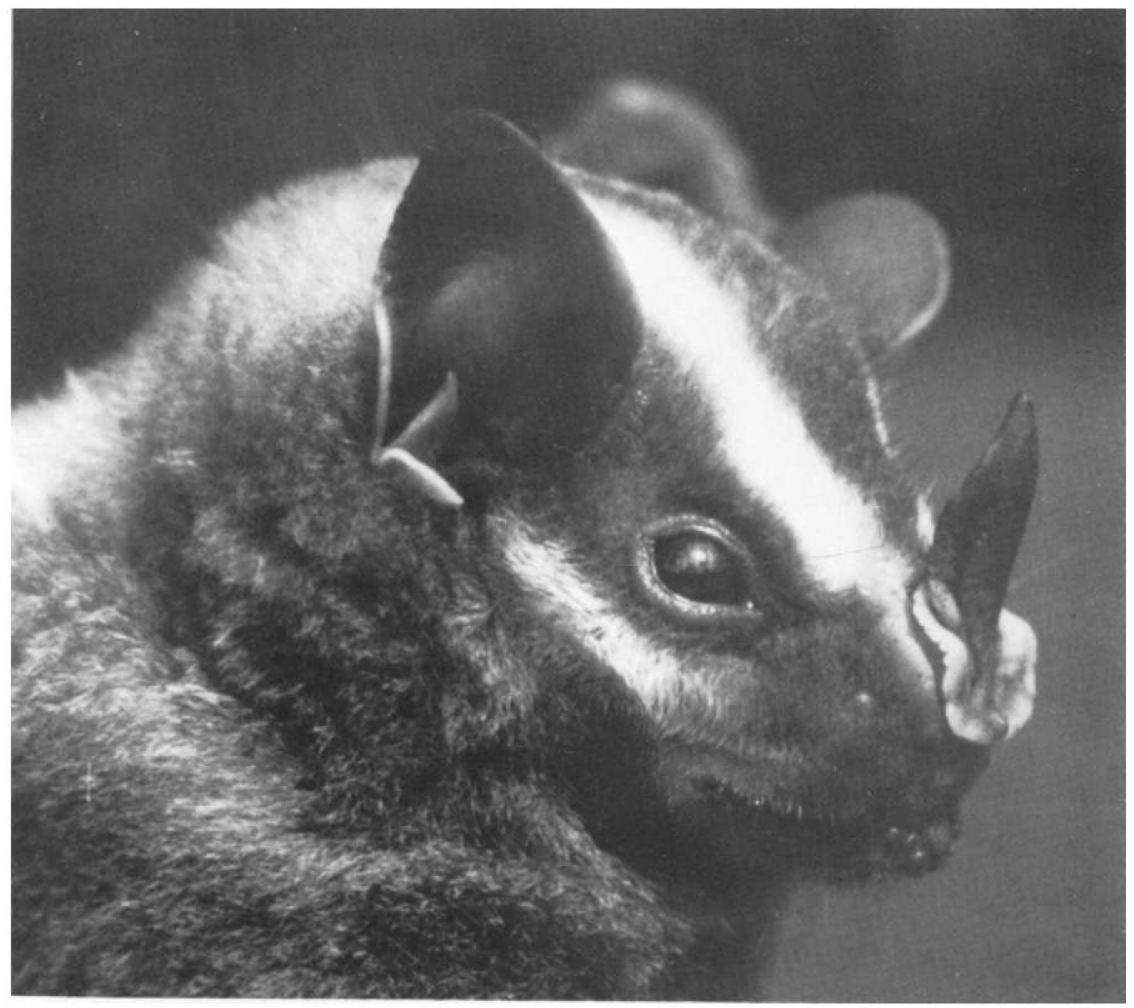

Fig. 64. San Pablo bat, Vampyrodes caraccioli. Photo by R. K. LaVal. 


\section{Vampyrops helleri \\ Heller's Broad-nosed Bat}

Heller's broad-nosed bats occur from Oaxaca and Veracruz, Mexico, to central Brazil (Fig. 65). If subspecies are recognized in Vampyrops helleri, the nominate form occurs throughout Central America.

This species is found in primary forest habitats and occasionally in secondgrowth and riparian situations. Roost sites include caves, tunnels, buildings, culverts, and bridges, as well as foliage (Tuttle 1976). Although essentially frugivorous, this species occasionally takes insects (Howell and Burch 1974). Data on reproduction are too few to suggest a definitive pattern (Wilson 1979).

Goodwin (1946) reported a specimen from Jiménez, Limón Province. Mares and Wilson (1971) added specimens from the Osa Peninsula and San Vito, Puntarenas Province. LaVal and Fitch (1977) reported 17 from La Selva; their only pregnant female was found in August. We took two males in Parque Nacional Braulio Carrillo, both from primary forest on a well-drained ridge.

Specimens examined (9)-Finca La Selva, $3 \mathrm{~km} \mathrm{~S}$ of Puerto Viejo, $70 \mathrm{~m}$ [2 females, KU; 3 males, 2 females, LACM]; $11 \mathrm{~km} \mathrm{~S}, 4.5 \mathrm{~km}$ W of Puerto Viejo, $270 \mathrm{~m}$ [1 male, USNM; 1 male, UNA].

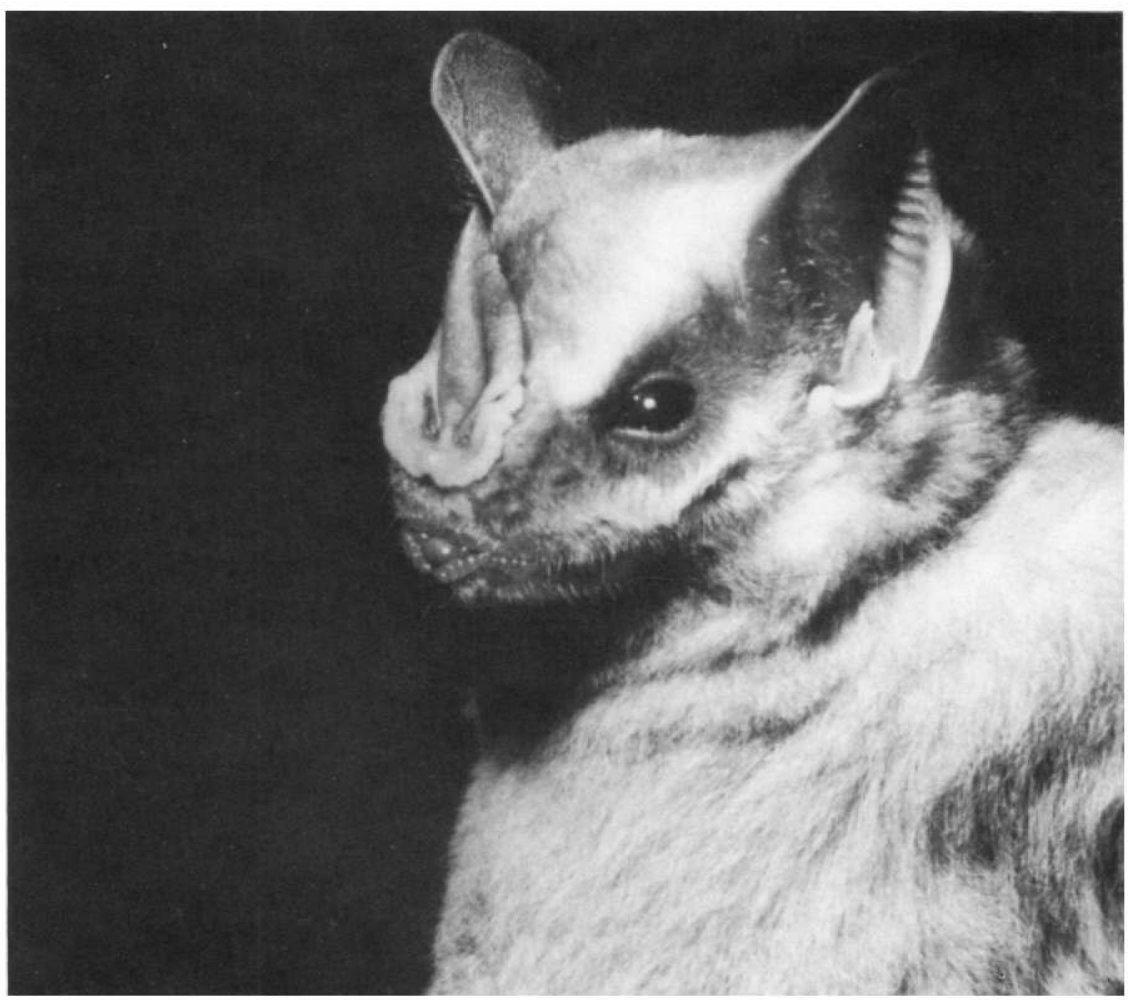

Fig. 65. Heller's broad-nosed bat, Vampyrops helleri. Photo by B. L. Clauson. 


\section{Vampyrops vittatus Greater Broad-nosed Bat}

Greater broad-nosed bats reach their northern limit in Costa Rica, and extend as far south as Bolivia (Fig. 66). Vampyrops vittatus is a monotypic species.

This broad-nosed bat is most common at intermediate elevations in wet and moist forest habitats (Handley 1976). Roosting sites have been reported from caves and tunnels, overhanging roots, and under stream banks (Tuttle 1976). Gardner (1977) listed this species as frugivorous. Little is known about the reproductive pattern, but the species is presumed to be bimodally polyestrous (Wilson 1979).

Dobson (1878) first reported $V$. vittatus from Costa Rica (undesignated locality), and Tamsitt and Valdivieso (1961) reported a second specimen from San José. Davis et al. (1964) collected 9 specimens from Cariblanco, Alajuela Province, and Gardner et al. (1970) reported 16 from Vara Blanca, Heredia Province.

Specimens examined (16)-Vara Blanca [6 males, 10 females, LSUMZ].

\section{Subfamily Desmodontinae \\ Desmodus rotundus Common Vampire Bat, Vampiro}

Common vampires occur from Sonora and Tamaulipas, Mexico, to Argentina (Fig. 67). The Costa Rican subspecies, Desmodus rotundus murinus, occurs throughout Mexico and Central America.

Common vampires have adapted to a wide variety of habitats and prosper where man has introduced livestock. They are much less common in primary forest. Roost sites include caves, tunnels, hollow trees, culverts, bridges, and rock crevices (Tuttle 1976). The diet is restricted to blood, primarily mammalian, although we have also observed them feeding on chickens. Reproduction is continuous, probably due to the artifically high food supply provided by domestic livestock. The biology of vampires was summarized by Greenhall et al. (1983) and Greenhall and Schmidt (1988). Turner $(1975,1983)$ summarized natural history information for Costa Rica.

In a several-month study of vampires at La Selva, Young (1971) reported a colony of 40 to 47 individuals in the hollow of a large Ceiba pentandra tree, while a second colony of 54 to 68 individuals roosted between two gnarled buttresses of a giant Terminalia bucidoides tree (Combretaceae). One roost site also contained a colony of greater white-lined bats (Saccopteryx bilineata), but there was little to no interaction between the vampires and sac-winged bats. Young noted a high degree of site fidelity in the vampires. The individuals he observed typically fed on cattle located $2.4 \mathrm{~km}$ from the roosting sites. Although he found reproduction concentrated in a 2 month period (March through April), investigators in other areas have found vampires to breed the year around.

Goodwin (1946) reported specimens from Cartago Province. Mares and Wilson (1971) reported vampires from Guanacaste Province and also seven specimens from La Selva. LaVal and Fitch added 29 from La Selva. Our specimens from Braulio Carrillo came from forested areas near old pastures. 
Fig. 66. Greater broadnosed bat, Vampyrops vittatus. Photo by R. K. LaVal.
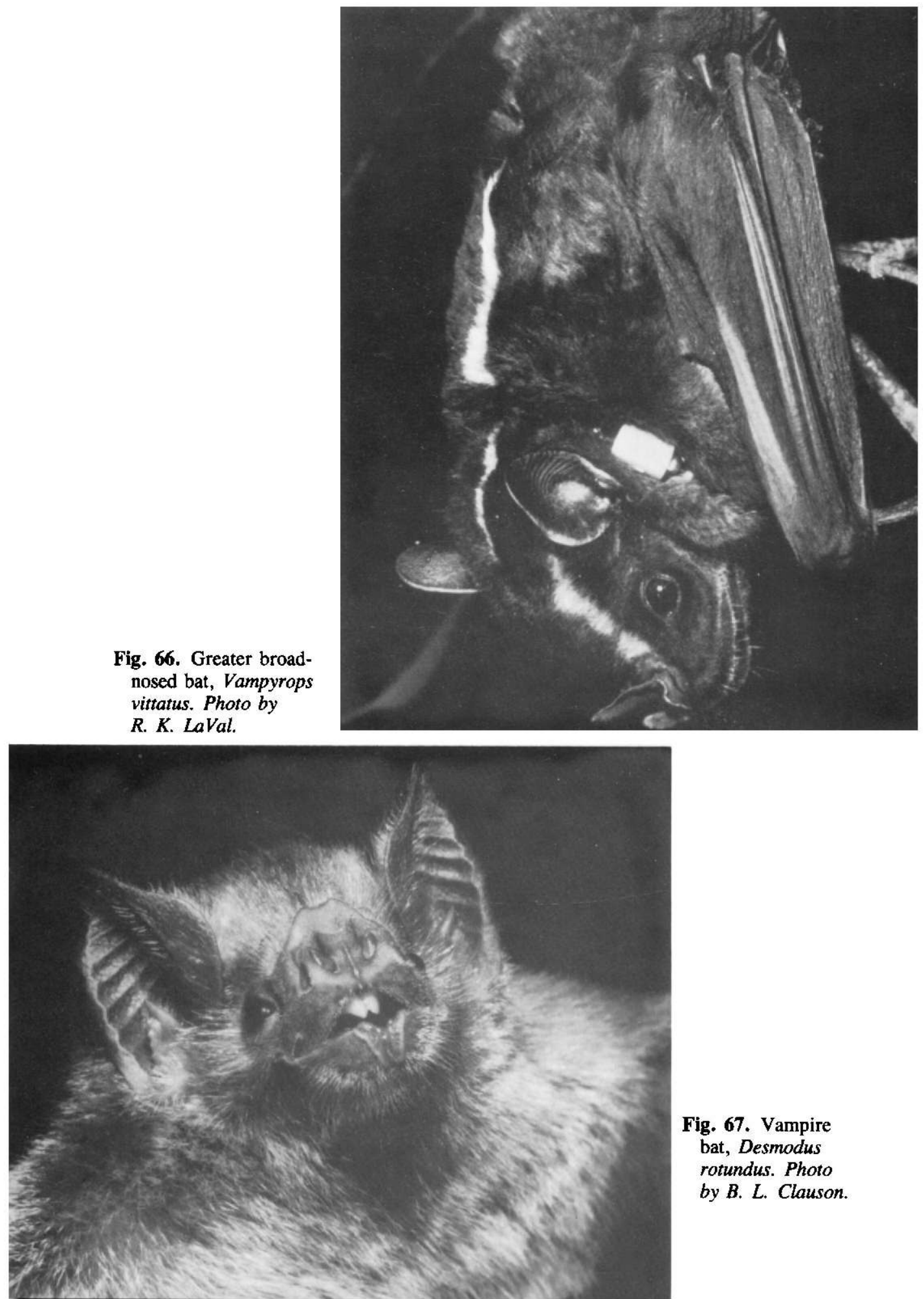

Fig. 67. Vampire bat, Desmodus rotundus. Photo by B. L. Clauson. 
Parasitic streblid bat flies we found on vampire bats include Strebla wiedemanni (1 female) and Trichobius parasiticus (1 male, 1 female).

Specimens examined (7)-Finca La Selva, $3 \mathrm{~km} \mathrm{~S}$ of Puerto Viejo, $70 \mathrm{~m}$ [1, LACM]; $11 \mathrm{~km} \mathrm{S,} 4.5 \mathrm{~km}$ W of Puerto Viejo, $270 \mathrm{~m}$ [1 female, USNM]; $1 \mathrm{~km}$ $\mathrm{S}, 11.5 \mathrm{~km}$ E of San Miguel, $580 \mathrm{~m}$ [ 3 females, USNM; 1 male, UNA]; $5 \mathrm{~km}$ $\mathrm{E}$ of Vara Blanca, $2,050 \mathrm{~m}$ [1 female, USNM].

Additional records (2)-4 mi W of Puerto Viejo, $300 \mathrm{ft}$ [1 female, TCWC]; Vara Blanca [LSUMZ; Gardner et al. 1970].

\section{Family Furipteridae \\ Furipterus horrens Smoky Bat}

Smoky bats reach the northern limit of their range in Costa Rica and are known from South America as far south as Brazil. Furipterus horrens is a monotypic genus and species.

Although this species is primarily restricted to mesic forest habitats, it has been reported from dry forest in South America (Uieda et al. 1980). Roost sites are in caves, hollow logs, and rock crevices (LaVal 1977; Uieda et al. 1980). Uieda et al. (1980) reported moths to be important dietary items. Scattered reports of reproductive activity are insufficient to speculate on the annual cycle.

LaVal (1977) found a roost in a hollow log at La Selva containing more than 59 individuals. This is the northernmost locality for the species, and the only known Costa Rican locality of record.

Specimens examined (2)-Finca La Selva, $3 \mathrm{~km} \mathrm{~S}$ of Puerto Viejo, $70 \mathrm{~m}$ [1 male, 1 female, KU].

\section{Family Thyropteridae}

\section{Thyroptera tricolor}

\section{Spix's Disk-winged Bat}

Spix's disk-winged bats are known from Veracruz, Mexico, to southern Brazil (Fig. 68). The Costa Rican subspecies, Thyroptera tricolor albiventer, occurs throughout Central America. Disk-winged bats occur from sea level to middle elevations.

This species is found in wet forest habitats with stands of Heliconia spp. Individuals roost inside the tubular emerging leaves of these plants and also of the introduced banana (Musa sapientum), holding onto the leaf with the unique suction cups on their wrists and ankles (Findley and Wilson 1974). They are insectivorous, but details of the diet are unknown. They roost in family groups, but details of the reproductive cycle are not available (Wilson and Findley 1977).

Goodwin (1946) reported the first Costa Rican specimens from Puntarenas Province. Starrett and de la Torre (1964) added a specimen from Golfito, and Gardner et al. (1970) also reported Thyroptera tricolor from the Osa Peninsula. Our specimen from Parque Nacional Braulio Carrillo was captured in a mist net across a narrow road through an old pasture, with primary forest nearby. Disk-winged bats have been observed at La Selva on only a few occasions. The specimen now at LACM was taken in the early 1960 's and was the first from the Caribbean 


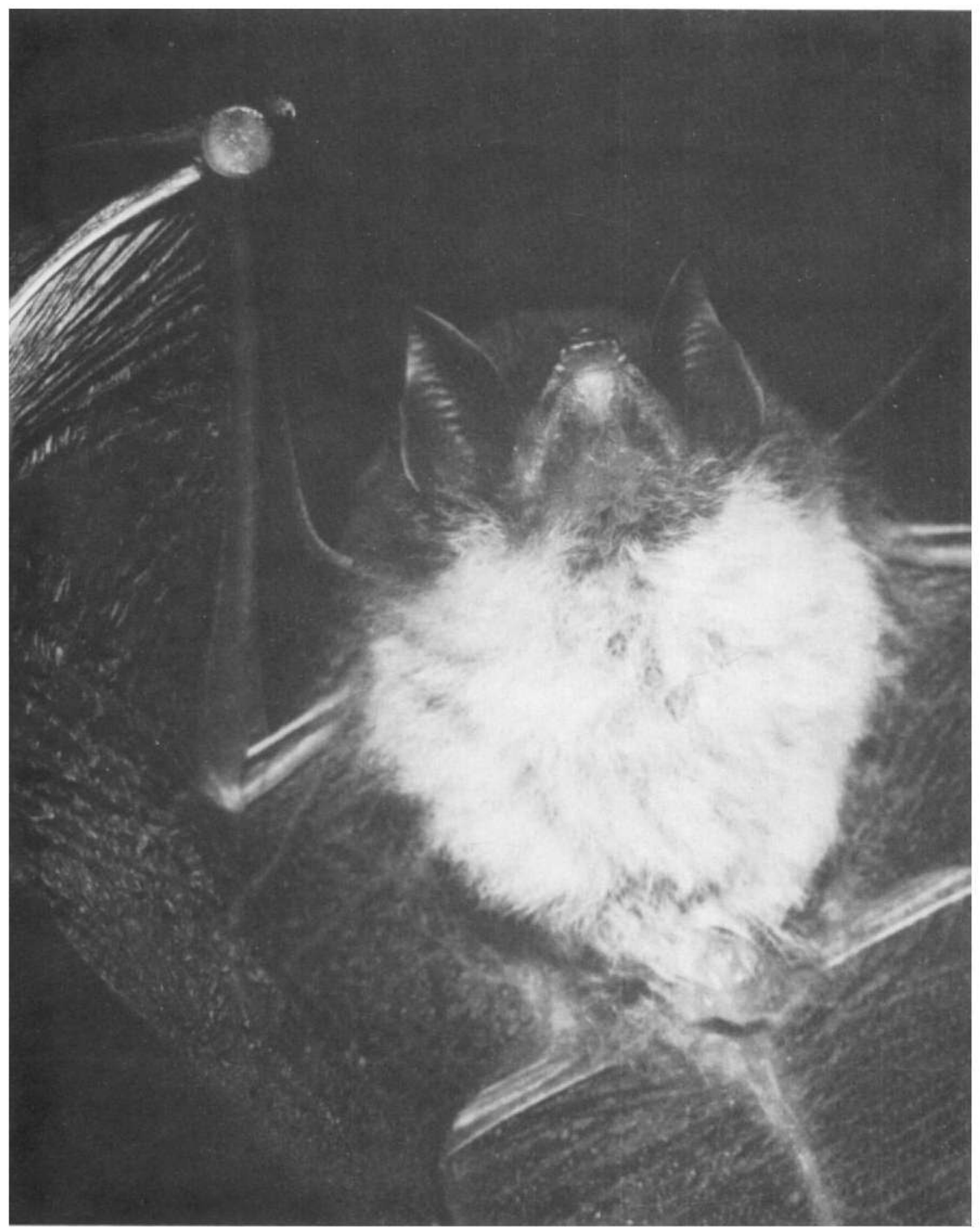

Fig. 68. Spix's disk-winged bat, Thyroptera tricolor. Photo by B. L. Clauson.

lowlands of Costa Rica. A single individual was recorded in the mammal log at La Selva on 23 May 1983. In June 1988, a colony of seven disk-winged bats was found in an unfurled Heliconia leaf near the field station at La Selva, and another colony was found in the same area in May 1989. Thyroptera is common in other lowland areas in Costa Rica. It is abundant at Tortuguero and on the Osa Peninsula, but may be locally restricted to areas that combine Heliconia stands with substantial canopy cover.

Specimens examined (2)-Finca La Selva, $3 \mathrm{~km} \mathrm{~S} \mathrm{of} \mathrm{Puerto} \mathrm{Viejo} \mathrm{[1} \mathrm{male,}$ LACM]; $11 \mathrm{~km} \mathrm{S,} 4.5 \mathrm{~km}$ W of Puerto Viejo, $270 \mathrm{~m}$ [1 female, USNM]. 


\section{Family Vespertilionidae \\ Eptesicus brasiliensis \\ Brazilian Brown Bat}

Brazilian brown bats are found from Veracruz, Mexico, to Argentina (Fig. 69). The Costa Rican subspecies, Eptesicus brasiliensis andinus, occurs in the highlands of Central America. It may warrant recognition as a distinct species $(E$. andinus).

Although this species normally is found in highland areas in Central America, its presence at La Selva (LaVal and Fitch 1977) and at $270 \mathrm{~m}$ in the Zona argues for broader habitat tolerance. These bats frequently roost in buildings or in hollow trees (Handley 1976). They are insectivorous, but details of the diet are unknown. Reproductive records suggest the possibility of a polyestrous pattern.

This species has been taken at several localities in the highlands of Costa Rica (Starrett and Casebeer 1968). LaVal and Fitch (1977) captured one at La Selva. Our lowland specimen from Parque Nacional Braulio Carrillo was caught in a net placed over a small stream, and the highland specimen was netted in an old pasture near a small strip of riparian forest.

Specimens examined (2)-11.5 km S, $4.5 \mathrm{~km} \mathrm{~W}$ of Puerto Viejo, $270 \mathrm{~m}$ [1 female, USNM]; $5 \mathrm{~km}$ E of Vara Blanca, 2,050 m [1 male, USNM].

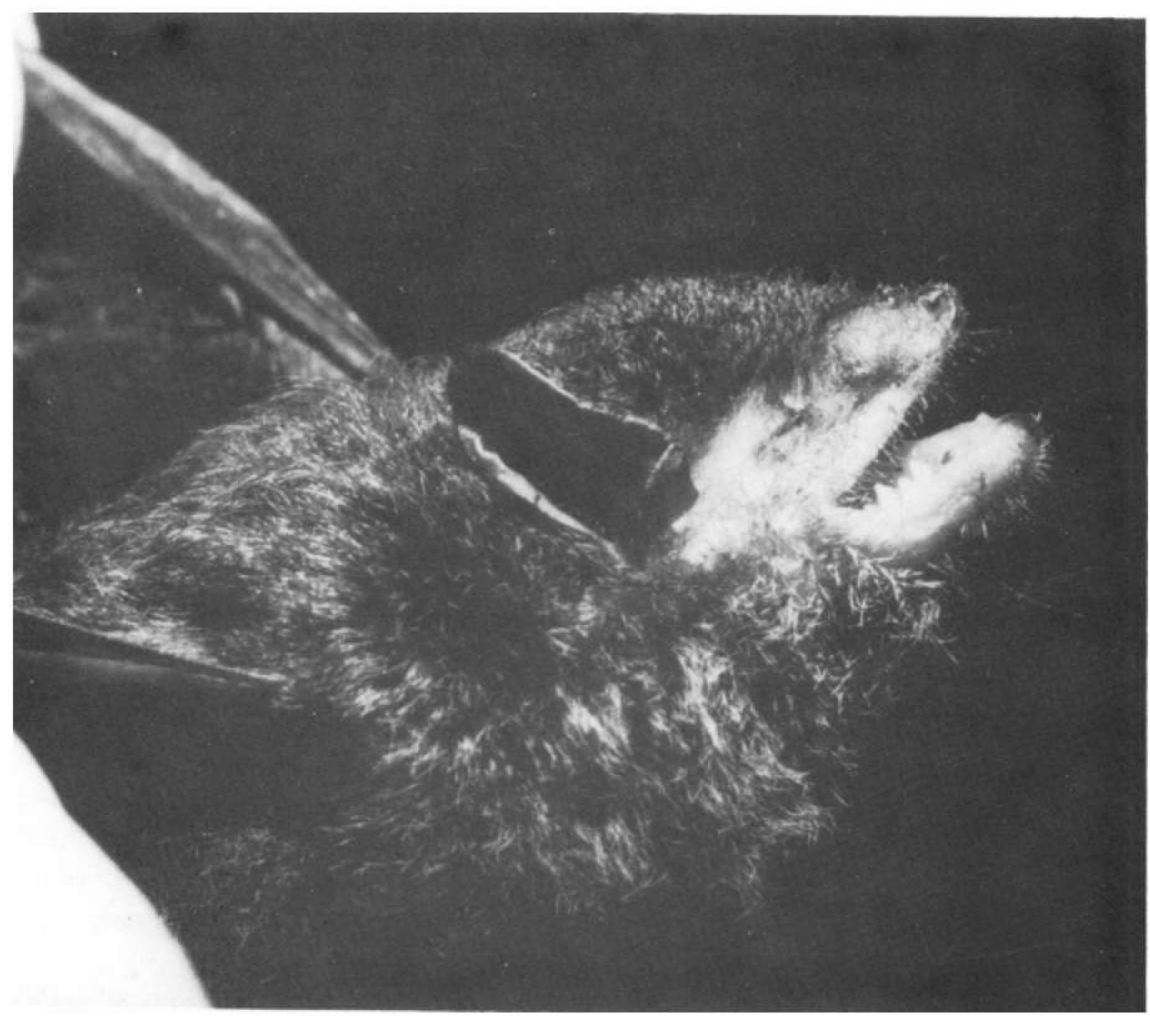

Fig. 69. Brazilian brown bat, Eptesicus brasiliensis. Photo by B. L. Clauson. 


\section{Eptesicus furinalis \\ Argentine Brown Bat}

Argentine brown bats range from Jalisco and Tamaulipas, Mexico, south to Argentina. Davis (1965) considered Costa Rican animals to belong to a distinct subspecies, which he described as Eptesicus gaumeri carteri. Subsequently (Davis 1966), he arranged both gaumeri and carteri as subspecies of the wide-ranging $E$. furinalis. Additional study of geographic variation in this species is warranted.

This species occurs in a wide range of environmental conditions from sea level to high montane habitats. Roosts are known from caves, buildings, hollow trees, and logs (Villa-R. 1967). These bats are insectivorous, but details of the diet are unknown. The reproductive cycle has not been studied adequately in any given locality.

Starrett and Casebeer (1968) listed specimens from Puntarenas, Limón, and Alajuela Provinces. LaVal and Fitch (1977) captured a single individual from La Selva. Apparently no specimens have been preserved from this region.

\section{Lasiurus ega Southern Yellow Bat}

Southern yellow bats are found from southeastern Texas and adjacent Mexico to Argentina. A single subspecies, Lasiurus ega panamensis, is known from Central America. Systematics of the genus Lasiurus, based on genic data, were reviewed recently by Baker et al. (1988).

This species has an enormous range, and has been taken in a wide variety of habitats ranging from xeric desert scrub to rainforest. These bats normally roost in foliage. Details of food habits are not known; however, the species is certainly insectivorous. These bats are monestrous; litter size varies from one to three (Nowak and Paradiso 1983).

Goodwin (1946) recorded this species from San José and Alajuela Provinces. Starrett and Casebeer (1968) added specimens from Puntarenas Province, and Gardner et al. (1970) recorded specimens from the Meseta Central. Our specimen is the first from the Caribbean slope of Costa Rica.

Specimen examined (1)-11 km S, $4.5 \mathrm{~km}$ W of Puerto Viejo, $270 \mathrm{~m}$ [1 male, USNM].

\section{Myotis albescens \\ Silver-tipped Myotis}

The silver-tipped myotis ranges from Chiapas, Tabasco, and Veracruz, Mexico, to Argentina. Myotis albescens, a monotypic species, is typical of lowland rain forests, although individuals were netted from as high as $1,500 \mathrm{~m}$ by LaVal (1973a).

These bats usually are found in areas of mature forest, although they also follow riparian corridors through disturbed habitats. They roost in caves, hollow trees, and buildings. They are strictly insectivorous. The reproductive cycle is one of seasonal polyestry (Myers 1977). 
Goodwin first reported the species from Costa Rica based on a specimen from Guanacaste Province. Gardner et al. (1970) added a specimen from the Caribbean lowlands. LaVal (1977) found two roosting in a building at La Selva, and five, including three pregnant females, roosting with Molossus sinaloae in a building in Puerto Viejo in January. One species of bat fly, Basilia costaricensis (two females), was obtained on a single $M$. albescens at La Selva.

Specimens examined (3)-Finca La Selva, $3 \mathrm{~km} \mathrm{~S}$ of Puerto Viejo, $70 \mathrm{~m}$ [1 male, KU; 1 male, LACM]; $1 \mathrm{~km} \mathrm{S,} 11.5 \mathrm{~km} \mathrm{E}$ of San Miguel, $270 \mathrm{~m}$ [1 female, USNM].

\section{Myotis elegans \\ Elegant Myotis}

The elegant myotis occurs from San Luis Potosí, Mexico, to Costa Rica (Fig. 70). The species is monotypic. Myotis elegans is among the smallest of the Neotropical myotis. It is a lowland species, typically found from sea level to $300 \mathrm{~m}$, although it is known from as high as $750 \mathrm{~m}$.

Most individuals have been taken in forested areas, both wet and dry. Roosts have not been described. This is an insectivorous species. Although occasional reproductively active individuals have been reported, nothing is known about the annual pattern.

This species reaches the known southern limit of its range in Costa Rica, where it is known only from the La Selva area and Guanacaste Province (LaVal 1973a, 1977). LaVal caught 20 at La Selva. An undescribed species of bat fly (Nycteribiidae) of the genus Basilia (1 male, 3 females) was collected on an elegant myotis at La Selva.

Specimens examined (2)-5.5 mi N, $1 \mathrm{mi}$ E of Puerto Viejo, $120 \mathrm{~m}$ [1 female, TCWC]; Finca La Selva, $3 \mathrm{~km} \mathrm{~S}$ of Puerto Viejo, $70 \mathrm{~m}$ [1 male, KU].

\section{Myotis keaysi \\ Hairy-legged Myotis}

Bats of this polytypic species are found from Tamaulipas, Mexico, throughout Central America except for most of Panama, then south in South America to Peru. The Costa Rican subspecies is Myotis keaysi pilosatibialis. In Central America as a whole, the elevational range of hairy-legged myotis is from sea level to more than $2,500 \mathrm{~m}$. Interestingly, all lowland records of this species are from north of Honduras.

This bat has been taken in a variety of habitats ranging from arid scrub to tropical rain forest. Few roosts have been documented, but individuals use caves, hollow trees, and perhaps buildings in some areas. The species is definitely insectivorous. The reproductive cycle is seasonal polyestry (LaVal and Fitch 1977). Individuals captured near San Miguel were taken in mist nets in undisturbed primary forest.

LaVal (1973a) reported hairy-legged myotis from several localities in Costa Rica. All Costa Rican localities of record for $M$. keaysi seem to be from middle and high elevations. The specimens taken from Cinco Esquinas, Heredia Province, were part of a colony of 200 individuals that W. E. Duellman found roosting at night under a bridge. 


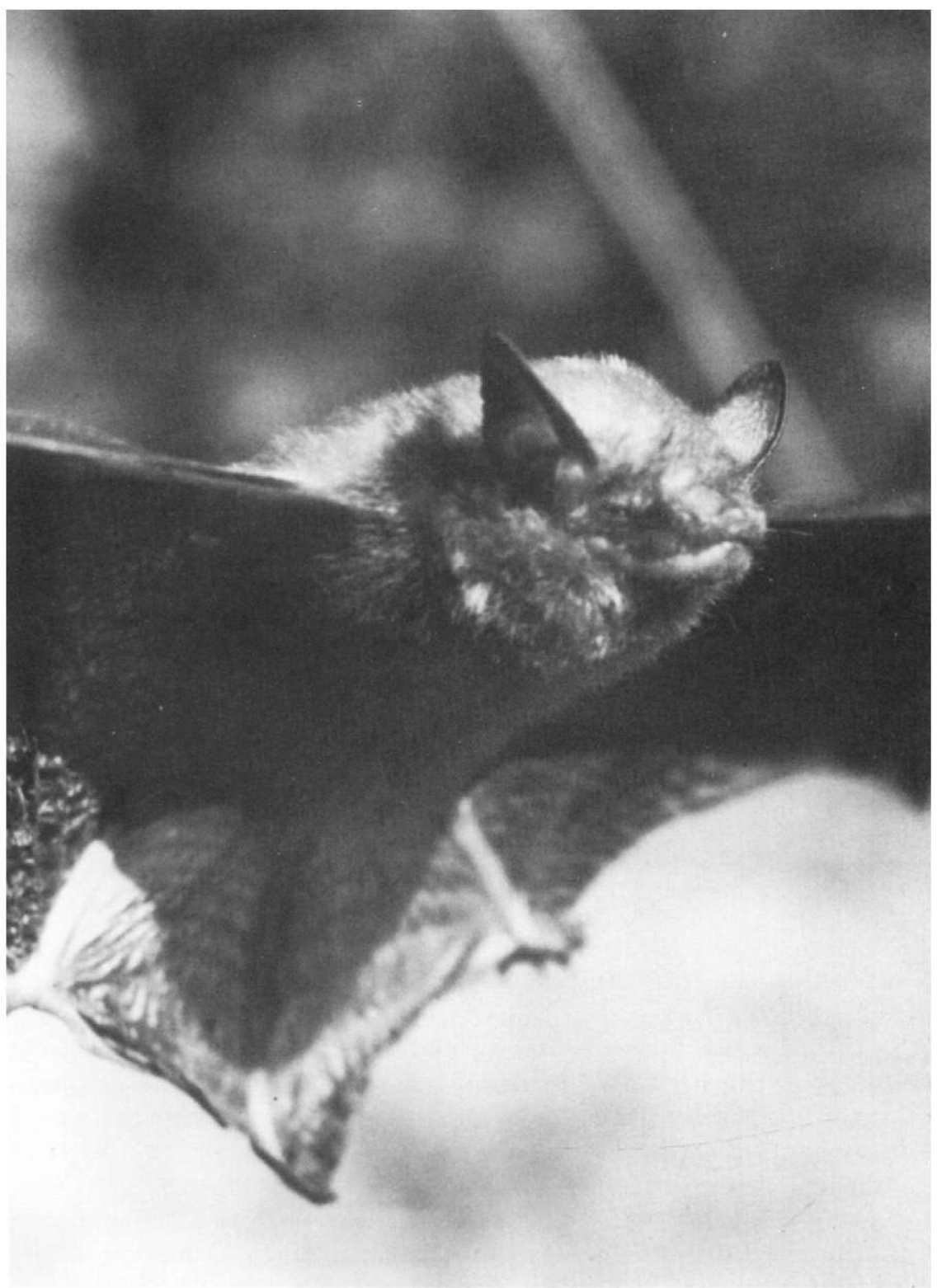

Fig. 70. Elegant myotis, Myotis elegans. Photo by R. K. LaVal.

Specimens examined (34)-2 km $\mathrm{N}$ of Cinco Esquinas, 1,550 m [21 males, 2 females, KU; 5 males, LACM]; $3.5 \mathrm{~km} \mathrm{S,} 11.5 \mathrm{~km}$ E of San Miguel, 1,000 m [1 male, UNA; 2 males, USNM]; Vara Blanca, 1,800 m [1, LSUMZ]; Volcán Barva, $3.2 \mathrm{~km} \mathrm{~S}$ of Los Cartagos, ca. 1,800 m [2, LACM]. 


\section{Myotis nigricans \\ Black Myotis}

The black myotis is distributed from Tamaulipas, Mexico, to Argentina (Fig. 71). The nominate subspecies, Myotis nigricans nigricans, is found throughout Central America.

This species is known from almost all vegetation types within its broad range. In Costa Rica it is found from sea level to above $3,000 \mathrm{~m}$. Black myotis roost in buildings, caves, tunnels, and hollow trees. The reproductive cycle is one of seasonal polyestry with a short diapause during the end of the rainy season (Wilson 1971b). The biology of black myotis was summarized by Wilson and LaVal (1974) and Wilson (1983b).

Goodwin (1946) reported black myotis from several Costa Rican localities, and subsequent workers have found this species occurring in most areas of the country. LaVal took 14 during his study at La Selva (LaVal and Fitch 1977). Our specimens from Parque Nacional Braulio Carrillo were caught in mist nets set over small streams near large tracts of primary forest. We obtained two species of bat flies on $M$. nigricans: Anatrichobius scorzai (1 female) and Basilia sp. (4 males, 3 females).

Specimens examined (19)-Puerto Viejo de Sarapiquí [ 2 males, 1 female, LACM]; Finca La Selva, $3 \mathrm{~km} \mathrm{~S}$ of Puerto Viejo, $70 \mathrm{~m}$ [1 female, KU]; $5.7 \mathrm{mi}$ $\mathrm{S}$ of Puerto Viejo [1 male, LACM]; $11 \mathrm{~km} \mathrm{S,} 4.5 \mathrm{~km}$ W of Puerto Viejo, $270 \mathrm{~m}$ [1 male, USNM]; $1 \mathrm{~km} \mathrm{~S}, 11.5 \mathrm{~km}$ E of San Miguel, $680 \mathrm{~m}$ [1 male, USNM]; Volcán Barva, $3.2 \mathrm{~km} \mathrm{~S}$ of Los Cartagos, ca. 1,800 m [12, LACM].

\section{Myotis oxyotus \\ Montane Myotis}

Montane myotis reach their northern limit in Costa Rica; the species extends south to Bolivia (Fig. 72). The Central American subspecies (LaVal 1973a) is Myotis oxyotus gardneri.

In Central America, the montane myotis is known only from highland areas of the Cordillera Talamanca in Panama and Costa Rica, and the Cordillera Tilaran of Costa Rica. The Vara Blanca specimen represents the northeasternmost record of the species. The habitat there is moist oak forests and cloud forests. We have also taken this species on several occasions in the Monteverde region. Montane myotis are insectivorous, but details of the food habits are unknown. The few records of reproductive activity (Gardner et al. 1970) suggest a monestrous cycle, with young born in summer.

The first Costa Rican records came from near Villa Mills on Cerro de la Muerte (Starrett and Casebeer 1968). Gardner et al. (1970) collected specimens from San José and Cartago Provinces in addition to the single male from Vara Blanca in Heredia Province.

Specimen examined (1)-Vara Blanca, 1,800 m [1 male, LSUMZ]. 
Fig. 71. Black myotis, Myotis nigricans. Photo by $B$. L. Clauson.
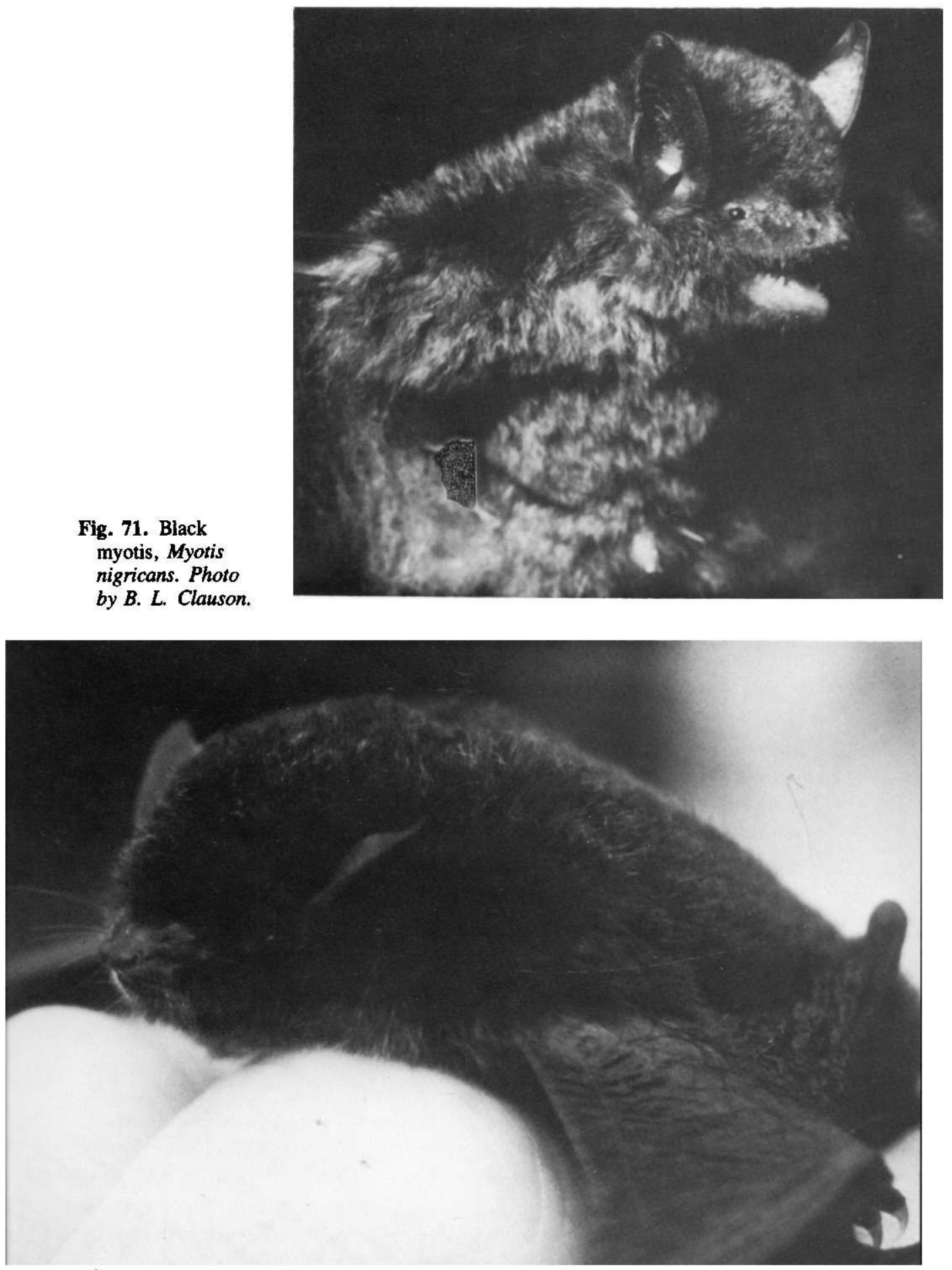

Fig. 72. Montane myotis, Myotis oxyotus. Photo by R. K. LaVal. 


\section{Myotis riparius \\ Riparian Myotis}

Myotis riparius, a monotypic species, is found from Honduras to Uruguay. It occupies a wide elevational range, and habitats include both forested and savannah regions. Roosting sites are not known. Like other members of this genus, Myotis riparius are strictly insectivorous. At La Selva, the reproductive cycle is monestrous (LaVal and Fitch 1977).

LaVal (1973a) reported specimens from Limón and San José Provinces. He found the species common at La Selva, where he captured 78 (LaVal and Fitch 1977).

Specimen examined (1)-Finca La Selva, $3 \mathrm{~km} \mathrm{~S}$ of Puerto Viejo, $70 \mathrm{~m}$ [1 male, KU].

\section{Rhogeessa tumida Central American Yellow Bat}

Central American yellow bats are found from Oaxaca and Tamaulipas, Mexico, to Brazil (Fig. 73). Rhogeessa tumida has been considered a monotypic species, although the degree of chromosomal and morphological variation present suggests that several biological species may be represented (LaVal 1973b).

Almost all types of habitats found within its range are occupied by $R$. tumida, which occurs from sea level to $1,500 \mathrm{~m}$ in Costa Rica (LaVal 1973b). They are known to roost in buildings (Goodwin 1946), and are insectivorous. Reproductive data suggest a limited breeding season, but are too few to understand the cycle.

The first record for Costa Rica was that of Sanborn (1932) from Guanacaste Province. Goodwin (1946) reported these specimens from Puntarenas Province. LaVal and Fitch (1977) captured one at La Selva. Our three specimens came from mist nets set across a small stream in primary forest.

Specimens examined (3)-11 km S, $4.5 \mathrm{~km} \mathrm{~W}$ of Puerto Viejo, $270 \mathrm{~m}$ [2 females, USNM; 1 female, UNA].

\section{Family Molossidae \\ Molossus bondae Bonda Mastiff Bat}

Bonda mastiff bats are known from Honduras to Colombia, Ecuador, Venezuela, and Guyana (Fig. 74). The species is monotypic, and seems to be limited to forested regions in the Caribbean versant in the northern part of its range. Colonies commonly roost in buildings. The diet is made up completely of insects, which are taken on the wing. Little is known of reproduction, but pregnant females have been recorded in August and January in Costa Rica (LaVal 1977).

First reports of this species from Costa Rica were by Gardner et al. (1970), based on specimens from Cartago and Limón Provinces. LaVal (1977) reported a colony roosting under the roof of a building in Puerto Viejo. We captured and released an adult male and female at La Selva in June 1982. We mist-netted a single individual in Braulio Carrillo over a quiet pool in a small stream flowing through a recently cleared pasture. 


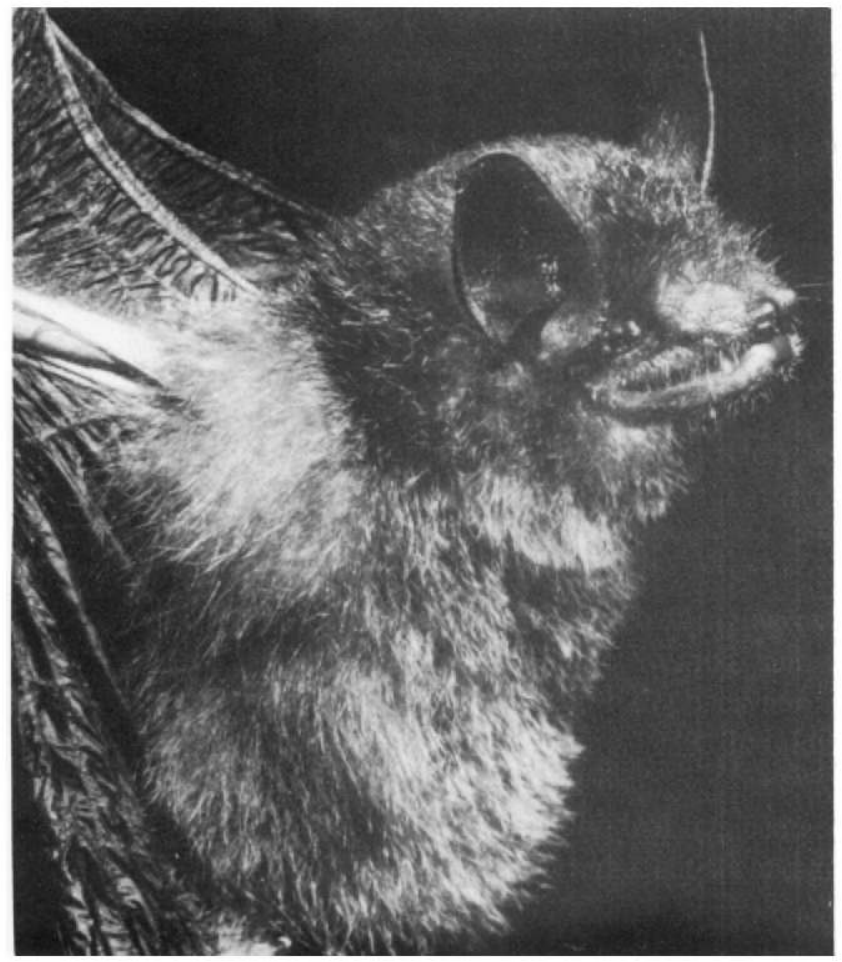

Fig. 73. Central American yellow bat, Rhogeessa tumida. Photo by B. L. Clauson.

Fig. 74. Bonda mastiff bat, Molossus bondae. Photo by B. L. Clauson.

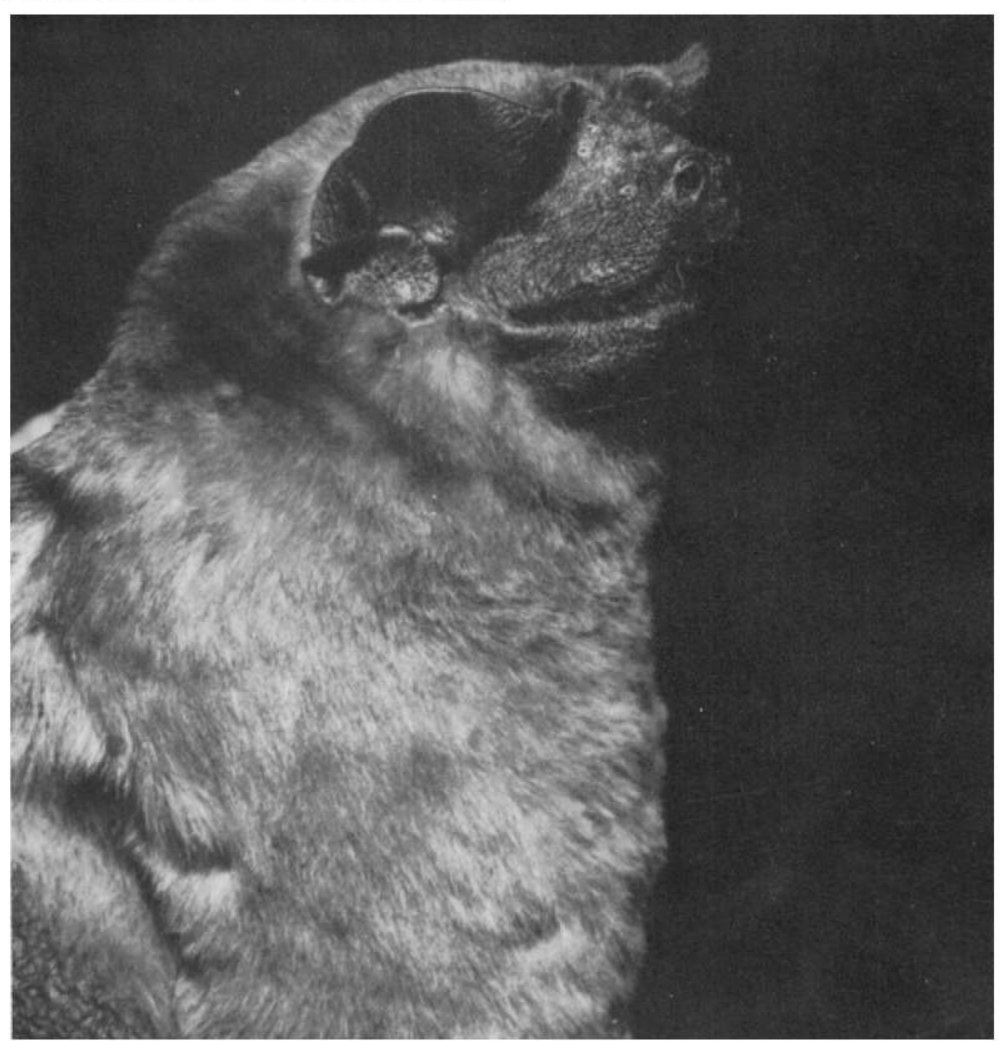


Specimen examined (1) $-1 \mathrm{~km} \mathrm{S,} 11.5 \mathrm{~km}$ E of San Miguel, $680 \mathrm{~m}$ [1 female, USNM].

\section{Molossus sinaloae}

\section{Allen's Mastiff Bat}

Allen's mastiff bats are found from Sinaloa to Suriname (Fig. 75). Hall (1981) recognized two subspecies as occurring in Costa Rica, Molossus sinaloae sinaloae in the north (including La Selva) and $M$. s. trinitatus in the south. Dolan (1982), however, regarded $M$. sinaloae as a monotypic species.

This mastiff bat has been taken in a wide variety of habitats in both wet and dry forest regions, and it commonly roosts in buildings. It is completely insectivorous. The reproductive cycle appears to be continuous (LaVal and Fitch 1977).

Goodwin (1946) reported specimens from Alajuela Province. LaVal and Fitch (1977) reported capturing 76 from a single colony roosting in a building in Puerto Viejo.

Specimens examined (23)-Puerto Viejo, Río Sarapiquí, 70 m [1 male, 7 females, KU; 4 males, 11 females, UMMZ].

Fig. 75. Allen's mastiff bat, Molossus sinaloae. Photo by R. K. LaVal. 


\section{Tadarida brasiliensis Brazilian Free-tailed Bat}

Brazilian free-tailed bats occur from the southern United States to Argentina (Fig. 76). The nominate subspecies, Tadarida brasiliensis brasiliensis, occurs throughout Costa Rica and south into South America.

This species is migratory, at least in the northern parts of its range. In Costa Rica, most records have come from higher elevations. Roosts are known from caves, tunnels, bridges, and buildings. The diet is composed entirely of insects. In the northern part of the range, this bat is monestrous and females form huge maternity colonies in summer. The reproductive cycle has not been studied in tropical areas.

Brazilian free-tailed bats were first recorded from Costa Rica by Allen (1892). Starrett and de la Torre (1964) collected 12 from a colony in a building in San José de la Montaña. The male from San Miguel de la Montaña was collected from a colony of perhaps a couple of hundred individuals that roosted in the hollow walls of a home. The volume of urine produced by this colony was so great that the walls were badly stained and the house smelled strongly of urine.

Specimens examined (13)-San José de la Montaña, 1,520 m [1 male, 11 females, LACM]; San Miguel de la Montaña, el. 1,690-1,700 m [1 male, KU]; Vara Blanca [LSUMZ].

Fig. 76. Brazilian free-tailed bat, Tadarida brasiliensis. Photo by M. D. Tuttle.

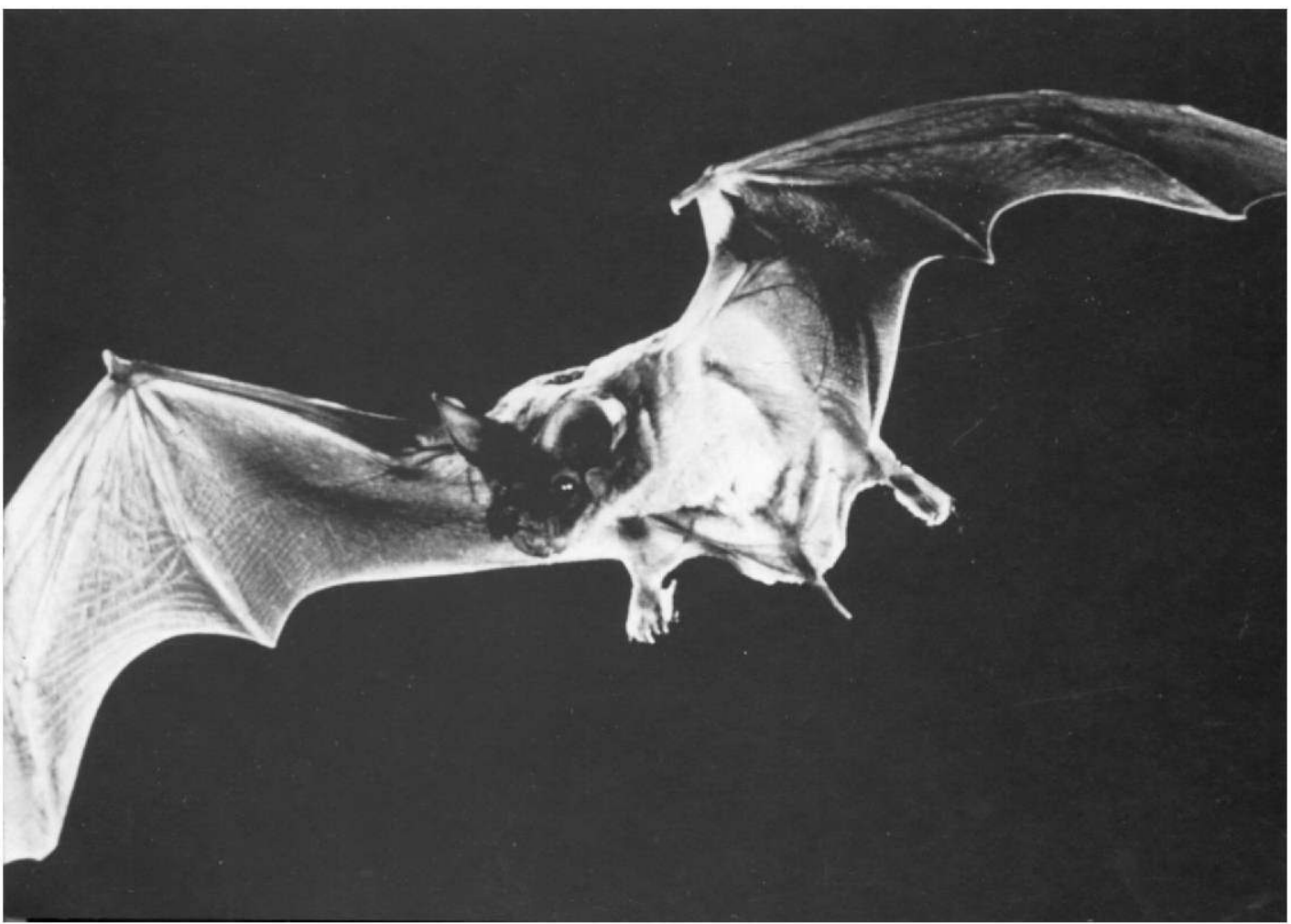




\section{ORDER PRIMATES}

Primates currently are protected throughout Costa Rica, and probably little poaching occurs. However, historically in this region, spider, howler, and capuchin monkeys were a meat source. Use of these primates for food continued in some areas of Costa Rica as late as the early 1970's, and undoubtedly the indigenous Indians in remote areas are still harvesting them. As the monkeys at La Selva in recent years have received complete protection from hunters, they are undoubtedly less wary of humans. Perhaps their recent abundance is attributable to a decrease in wariness and thus increased visibility as well as an increase in absolute numbers.

Primate populations throughout much of the Caribbean lowlands of Central America were decimated by an epidemic of mosquito-borne yellow fever during the early 1950's (see Fishkind and Sussman 1987, and references therein). Although data are not available for La Selva or the adjacent Braulio Carrillo region, we assume that this epidemic had a tremendous negative effect on the populations of indigenous primates. Far fewer primates were observed at La Selva during the late 1960's, 1970 's, and early 1980's than in similar tracts of primary forest elsewhere in the Neotropics. During the past several years, however, primate populations at La Selva have certainly rebounded. It is now common to see capuchin, howler, and spider monkeys almost daily and often in large troops.

\section{Family Cebidae \\ Alouatta palliata \\ Mantled Howler Monkey, Mono Congo or Mono Aullador}

Mantled howler monkeys are found from southern Mexico south through Central America to extreme northwestern South America, where they occur on the western slope of the Andes in Colombia and Ecuador to Guayaquil (Fig. 77). Two subspecies are found from sea level to forested high elevations $(2,500 \mathrm{~m})$ in Costa Rica. The nominate race, Alouatta palliata palliata, is widespread in Costa Rica, including Parque Nacional Braulio Carrillo; $A$. p. aequatorialis is restricted to extreme southwestern Costa Rica on the Osa Peninsula. This species adapts well to the presence of humans, usually being as abundant near rural towns and in second growth forests as it is in primary forests.

Howler monkeys were seen or heard by us on numerous occasions in the park from the lower elevations to $1,200 \mathrm{~m}$. Although they are widespread in Costa Rica, howler monkeys are less abundant within Parque Nacional Braulio Carrillo than we have observed them to be in other areas of the country. Additionally, both howler monkeys and white-faced capuchins were wary of us, suggesting that they have been hunted in this area. Corroborating this is Vaughan's (1972) observation of howler monkeys that were shot for human consumption in the vicinity of Cariblanco.

Howler monkeys were observed along the trail from 100 to $200 \mathrm{~m}$; calling troops heard at 200,300 , and $700 \mathrm{~m}$; and a troop observed at $500 \mathrm{~m}$. This is a commonly reported species at La Selva, although it is not as abundant there as are white-faced capuchins (Timm, in press). These monkeys have been seen or heard howling at La Selva in every month of the year. Troop sizes are variable 


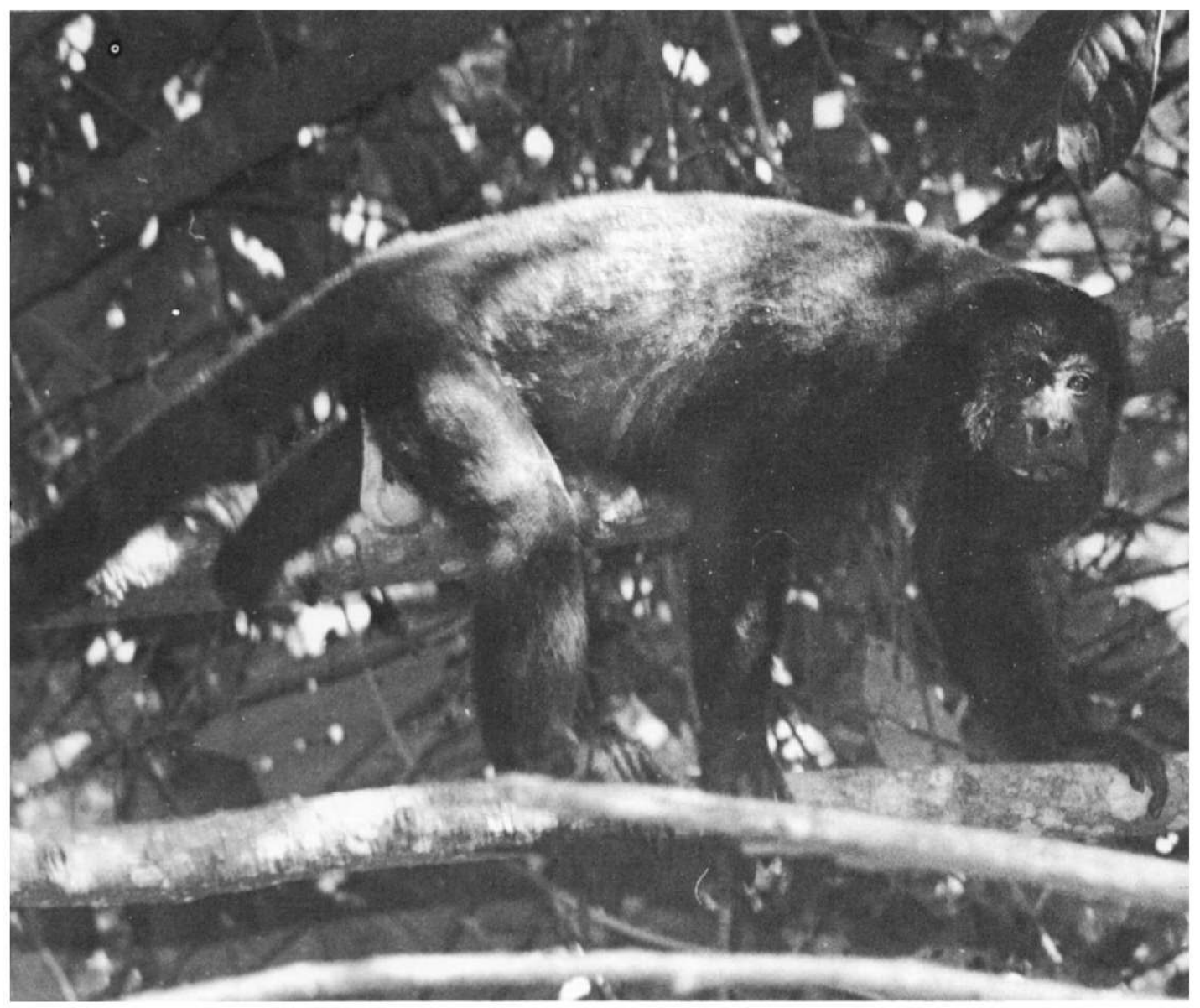

Fig. 77. Mantled howler monkey, Alouatta palliata. Photo by C. Thorington.

and may be as high as 10 or 11 . Lone individuals, which are usually males, are seen occasionally. Troops that included juveniles were seen in February 1983 (eight adults-three males, five females; two juveniles; and one infant), in April 1983 (three adults-one male, two females; one subadult female; one juvenile; and one infant in natal yellow coat), and in May 1986 (three adults-two males, one female; and one juvenile). Howler monkeys were observed eating the flower buds of Castilla elastica in April 1982 and the leaves of Cecropia sp. in November 1982; both plants are in the family Moraceae. In the late 1960 's only one troop of howler monkeys was known to occur on the La Selva property, but by 1980 two troops were regularly heard. The late foreman of La Selva, Rafael Chavarría, commented that before the 1953 yellow fever epidemic, howlers were extremely abundant along the Rio Puerto Viejo.

The biology of howler monkeys in Costa Rica was reviewed by Glander ( 1980 , 1983). 


\section{Ateles geoffroyi \\ Geoffroy's Spider Monkey, Mono Colorado or Mono Araña}

Geoffroy's spider monkey is primarily a Central American species found from southern Mexico through Central America to extreme northwestern Colombia (Fig. 78). In Costa Rica, three subspecies currently are recognized, although the group is in need of revision. Ateles geoffroyi ornatus is the most widely distributed subspecies in the country and is found in the eastern lowlands and central highlands; $A$. $g$. frontatus is restricted to the Guanacaste area of Costa Rica and most of Nicaragua; and $A$. g. panamensis is found in southwestern Costa Rica and much of Panama. Spider monkeys are found from sea level to nearly $2,200 \mathrm{~m}$ in suitable habitats, which are almost exclusively large tracts of undisturbed primary forest. It is the most widely hunted primate in Costa Rica.

We observed spider monkeys at 200 and $500 \mathrm{~m}$ within Parque Nacional Braulio Carrillo and learned that park guards frequently saw them at lower elevations within the park. There are probably at least two Ateles troops on the La Selva Biological Reserve, and groups numbering up to 23 individuals have been reported there since mammal records were begun in 1979. It is a commonly reported species at La Selva and has been observed year round. Group sizes vary considerably, but tend to be five or fewer. Lone animals are seen on occasion, and often these are males. Adults with young have been observed from nearly every month of the year; one or two infants may be seen in a troop. On one occasion, an adult male was seen traveling with a troop of six Cebus, and on another occasion an adult of unknown sex was with a troop of five Alouatta. A mixed group of two or three Ateles and five Cebus was seen in March 1986. Spider monkeys were observed feeding on the fruits of Dipteryx panamensis (Fabaceae) on 25 March 1986, seeds of Dussia (Fabaceae) in August and July, fruits of Protium (Burseraceae) in February, and fruits of Dendropanax (Araliaceae) in September. Rafael Chavarria informed Hartshorn (in litt.) that the large troops of spider monkeys (15 to 30 individuals) broke up during the day into smaller groups ( 2 to 5 individuals) for foraging. Spider monkeys were rarely observed at La Selva during the early 1970's.

Alston (1879-82:9) reported that spider monkeys were abundant in Costa Rica, "being found in the mountains up to an elevation of from six to seven thousand feet, as well as in the hot forests near the coast." The biology of spider monkeys was reviewed recently by Eisenberg (1983).

\section{Cebus capucinus \\ White-faced Monkey or White-faced Capuchin, Mono Cara Blanca}

White-faced capuchins are found from eastern Honduras and Nicaragua south through Costa Rica to northwestern Colombia and Venezuela (Fig. 79). A single subspecies, Cebus capucinus imitator, is found in Costa Rica from sea level to $3,000 \mathrm{~m}$. This species is adapted to a variety of habitat types and, although it is legally protected in Costa Rica, as are the other species of monkeys, it is not endangered. The biology of white-faced monkeys in Costa Rica recently was reviewed by Freese (1983). We have the general impression that all three species of primates 


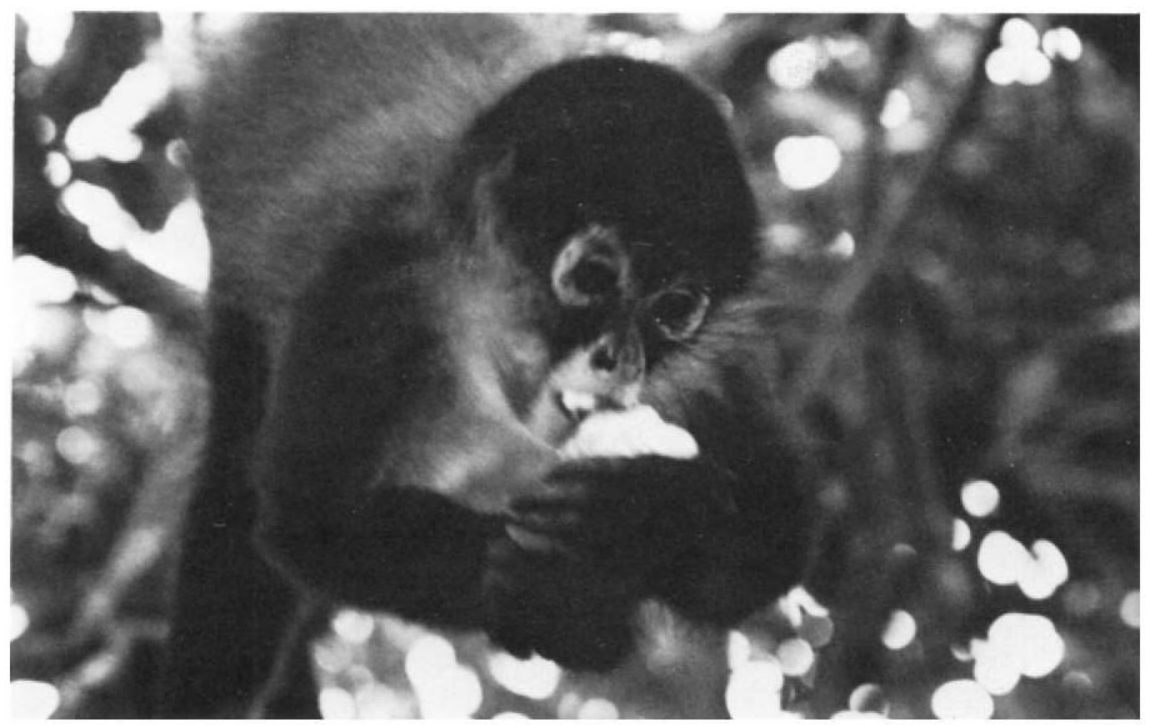

Fig. 78. Geoffroy's spider monkey, Ateles geoffroyi. Photo by D. E. Wilson.

are more common at La Selva now than when the Organization for Tropical Studies acquired the property in 1968 .

White-faced monkeys are one of the most abundant and frequently seen mammals at La Selva. Individuals can be observed on a daily basis if an effort is made to locate them. There are records from the La Selva property for every month of the year. Cebus capucinus is most often seen in groups of four to five; however,

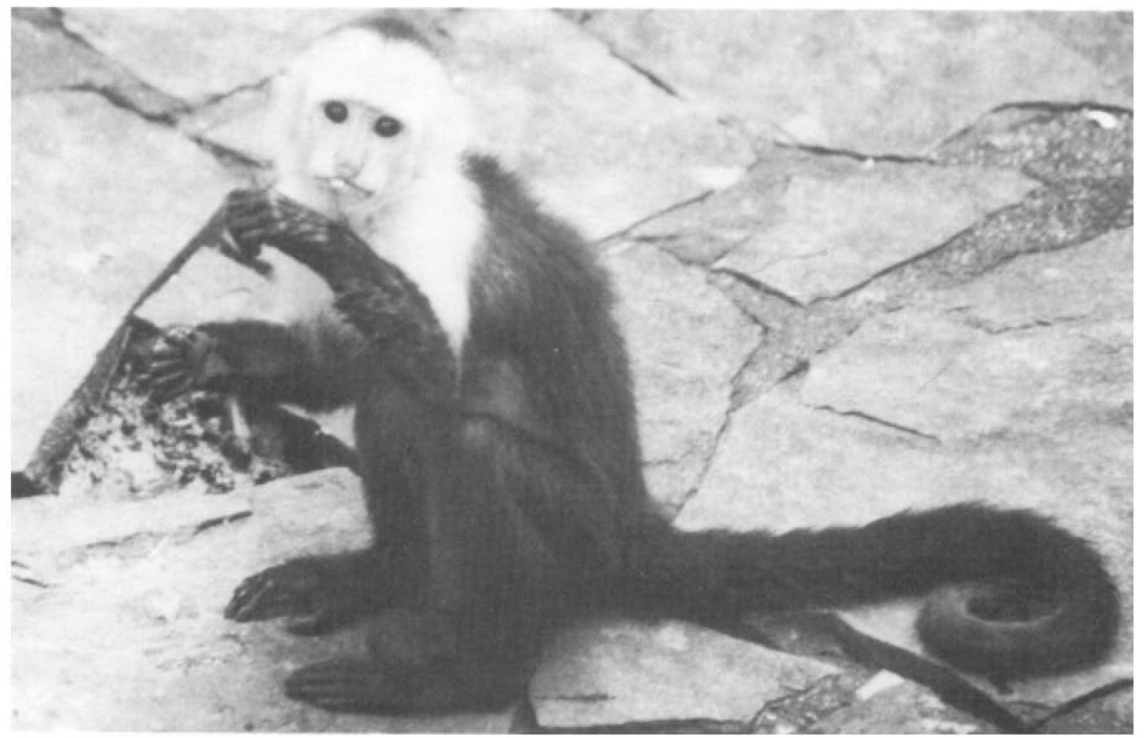

Fig. 79. White-faced capuchin, Cebus capucinus. Photo by N. Woodman. 
lone individuals, most likely males, have been observed on several occasions. The largest groups observed contained 15 to 20 individuals. Juveniles are first seen in January. On 7 January 1987, seven adults and one juvenile were observed; on 21 January 1987, seven or eight adults and two juveniles were observed; on 22 January 1987, an adult female near term was seen. In May and June of 1986, one or more troops ranging from five to nine adults with two infants were observed on several occasions. On two occasions, troops of $C$. capucinus have been observed in trees adjacent to troops of howler monkeys; on one occasion, a male spider monkey was seen with a troop of capuchins and on another a mixed group of $C$. capucinus and Ateles geoffroyi was seen together. On 16 September 1982, five $C$. capucinus were observed eating the fruits of Pourouma aspera (Moraceae). They were seen eating Inga sp. (Mimosaceae) on 21 October 1982 and fruits of Minquartia guianensis (Olacaceae) on 24 October 1982. White-faced monkeys were seen eating the fruits of Dipteryx panamensis on 31 July 1983 and those of Welfia georgii in April, July, August, and October. They feed by "breaking off entire rachillae, chewing the exocarp off individual fruits, eating the mesocarp, and dropping the undamaged seeds and the broken rachillae to the ground" (Vandermeer et al. 1979:19). They are probably important dispersers of Welfia seeds.

We observed Cebus capucinus on 14 occasions within Parque Nacional Braulio Carrillo at elevations of $100,300,700$, and $1,540 \mathrm{~m}$. Group sizes of 10 or more were seen between $100 \mathrm{~m}$ and $300 \mathrm{~m}$, whereas group sizes were smaller at higher elevations. White-faced capuchins at lower elevations were quiet when approached and frequently retreated quickly and quietly, whereas at higher elevations they often would display aggressive behavior. We interpret this to indicate greater hunting pressures on these monkeys at lower elevations.

\section{ORDER XENARTHRA}

\section{Family Bradypodidae \\ Bradypus variegatus Three-toed Sloth, Perezoso de Tres Dedos}

Three-toed sloths are found from extreme eastern Honduras southward through much of tropical South America (Fig. 80). Two subspecies of three-toed sloths are found in Costa Rica, Bradypus variegatus castaneiceps in the north and east, the race at La Selva, and B. v. griseus in the west. In Costa Rica, they are abundant in moist forests from sea level to elevations of 500 to $600 \mathrm{~m}$. Bradypus variegatus is officially protected in Costa Rica as an endangered species, although we suspect that these animals are found in good numbers in appropriate habitats as indicated by Montgomery and Sunquist from their studies of three-toed sloths on Barro Colorado Island, Panama. Their apparent rarity probably stems from the fact that they are often difficult to see.

Three-toed sloths have been sighted on many occasions at La Selva. Interestingly, most of these records are from the dry season (December through April). This 


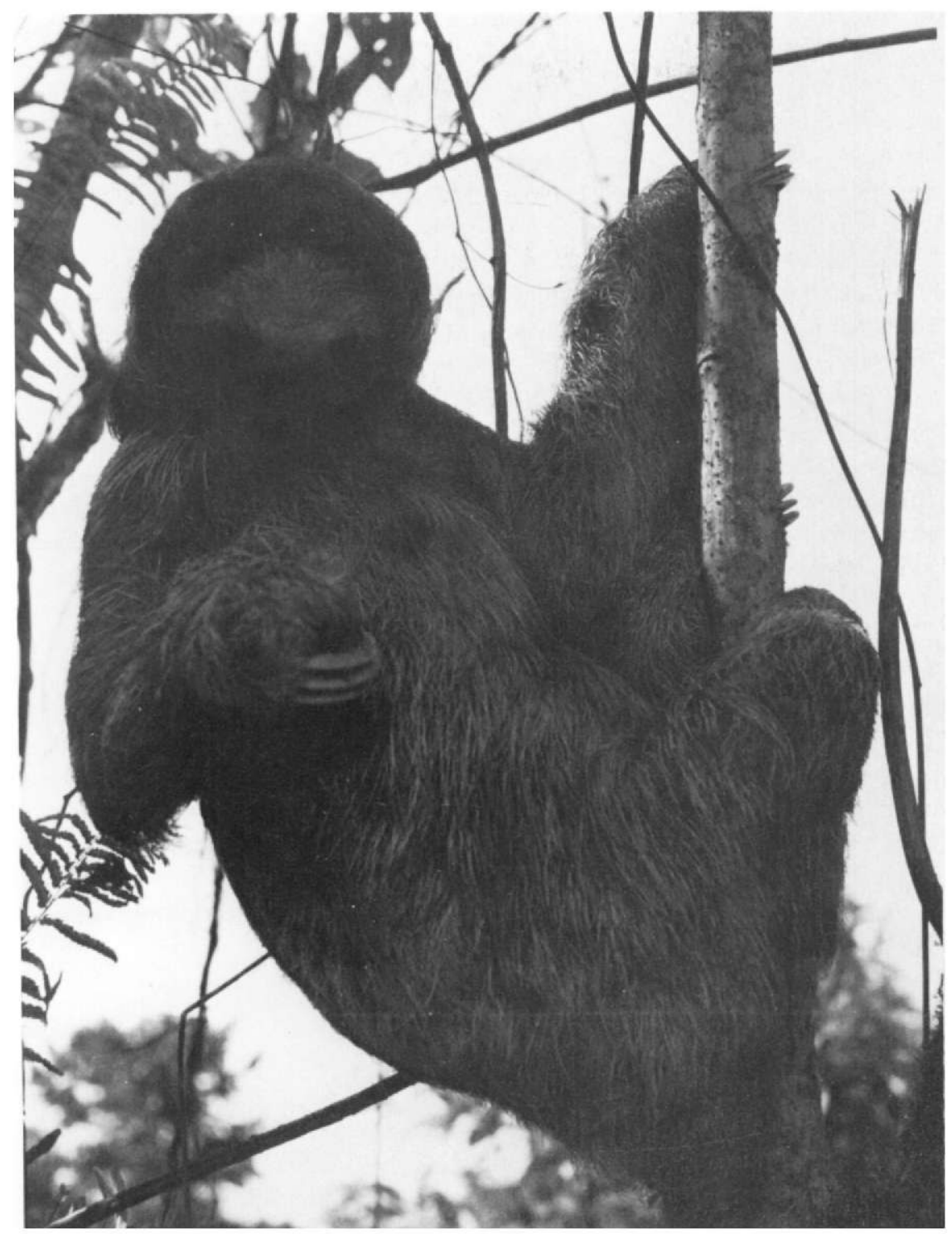

Fig. 80. Three-toed sloth, Bradypus variegatus. Photo by R. M. Timm. 
probably indicates that they are more visible during these months either because they are moving more or they are just more easily seen in their preferred trees. Several of the observed animals were in Cecropia trees, one of the favored food sources of this species. They are often visible from the foot bridge over the Río Puerto Viejo, where they can be seen in the Cecropia trees on the south bank. We observed a single three-toed sloth in Parque Nacional Braulio Carrillo at $200 \mathrm{~m}$ in March 1986.

Greene (in press) observed an aggressive interaction between two adult male three-toed sloths at La Selva. This is the first such observation on free-ranging sloths. He saw one sloth actively approach the other in a $C$. obtusifolia tree and witnessed that they struck each with their forefeet and emitted high pitched vocalizations. The aggressive encounter lasted some $3 \mathrm{~min}$ and ended when one sloth rapidly descended the tree. He also reported that 4 days later on 19 December 1987 "a pregnant female sloth was seen in the same tree, and one week later a female with young was seen ca. $100 \mathrm{~m}$ away." Greene (in press) concluded that these observations suggest that the social system and other natural history traits of sloths were more complex than has been previously thought. Sloths are one of the primary prey items taken by jaguars at La Selva (Greene, in litt.).

A discussion of the taxonomy of algae found in sloth hair was provided by Wujek and Timpano (1986) who described a blue-green alga, a branched, filamentous red alga, and two species of coccoid green algae based in part on material collected on sloths at La Selva.

The biology of three-toed sloths, primarily summarized from research on Barro Colorado Island, Panama, was reviewed recently by Montgomery (1983a). Excellent comprehensive reviews on the biology of sloths and other xenarthrans were provided by Montgomery $(1978,1985)$.

Specimens examined (2)-Puerto Viejo, Río Sarapiquí, 300 ft [2 females, UMMZ].

\section{Family Choloepidae \\ Choloepus hoffmanni \\ Two-toed Sloth, Perezoso}

Two-toed sloths are found from southeastern Nicaragua to northwestern Venezuela and Colombia (Fig. 81). The subspecies Choloepus hoffmanni hoffmanni is found throughout Costa Rica from sea level to at least $1,800 \mathrm{~m}$.

Two-toed sloths have been sighted on 14 occasions at La Selva. Observations of this species have been made throughout the year. Adults accompanied by single young have been seen on three occasions-twice during January and once in March. We observed a single two-toed sloth at $200 \mathrm{~m}$ in Parque Nacional Braulio Carrillo in March 1986.

Specimens examined (2)-Volcán Barva [1 female, CAL; 1 female, MVZ]. 


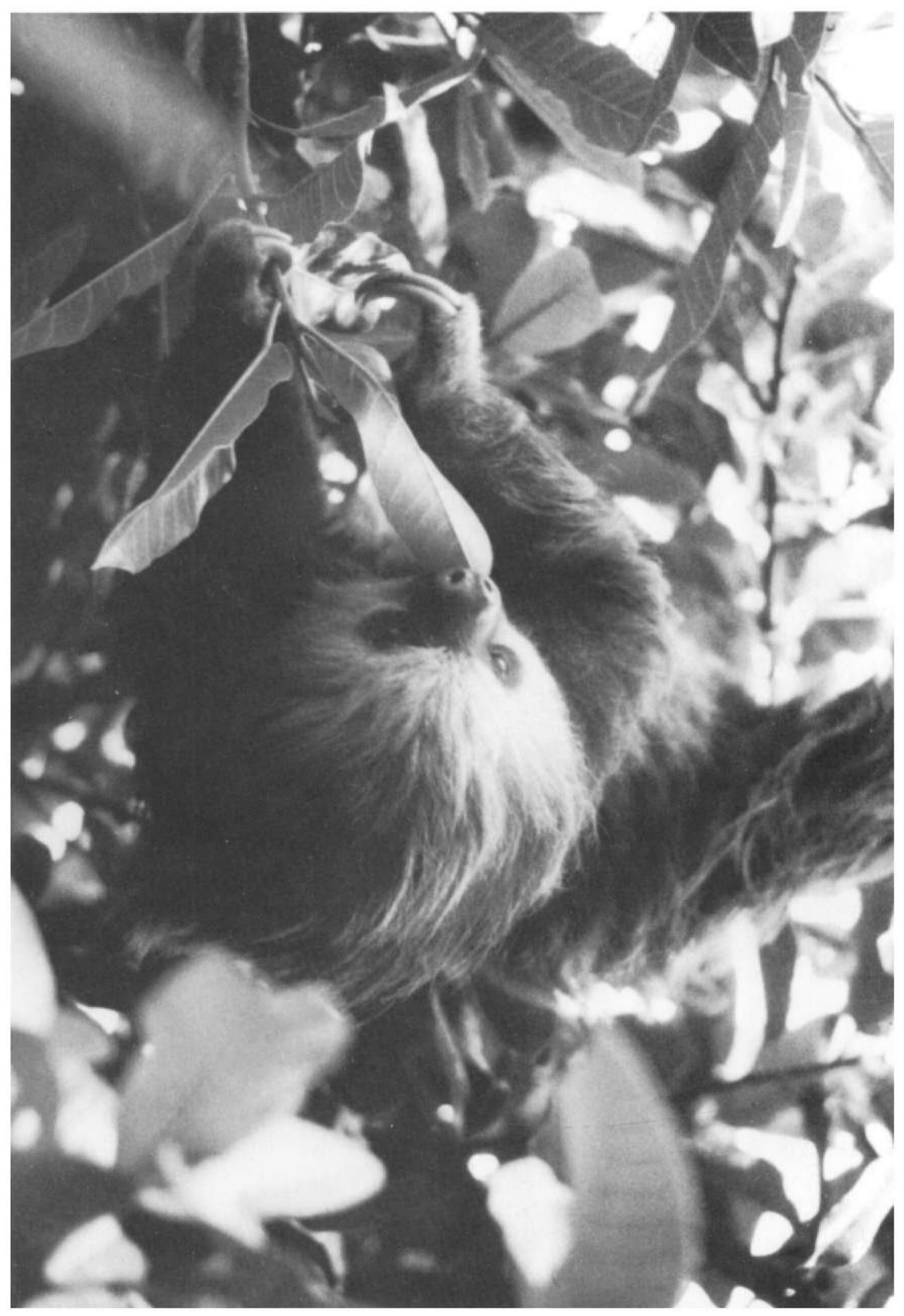

Fig. 81. Two-toed sloth, Choloepus hoffmanni. Photo by B. L. Clauson. 


\section{Family Dasypodidae}

\section{Cabassous centralis}

Central American Five-toed Armadillo, Armadillo Zopilote

Central American five-toed armadillos are found from southeastern Guatemala to northwestern Venezuela (Fig. 82). In Costa Rica, they are found from sea level to $1,800 \mathrm{~m}$. Cabassous centralis is a monotypic species (Wetzel 1980).

In March 1986 we observed Central American five-toed armadillos in Parque Nacional Braulio Carrillo at about $200 \mathrm{~m}$. Cabassous centralis has been observed at La Selva on only three occasions: 1973, August 1983, and December 1984.

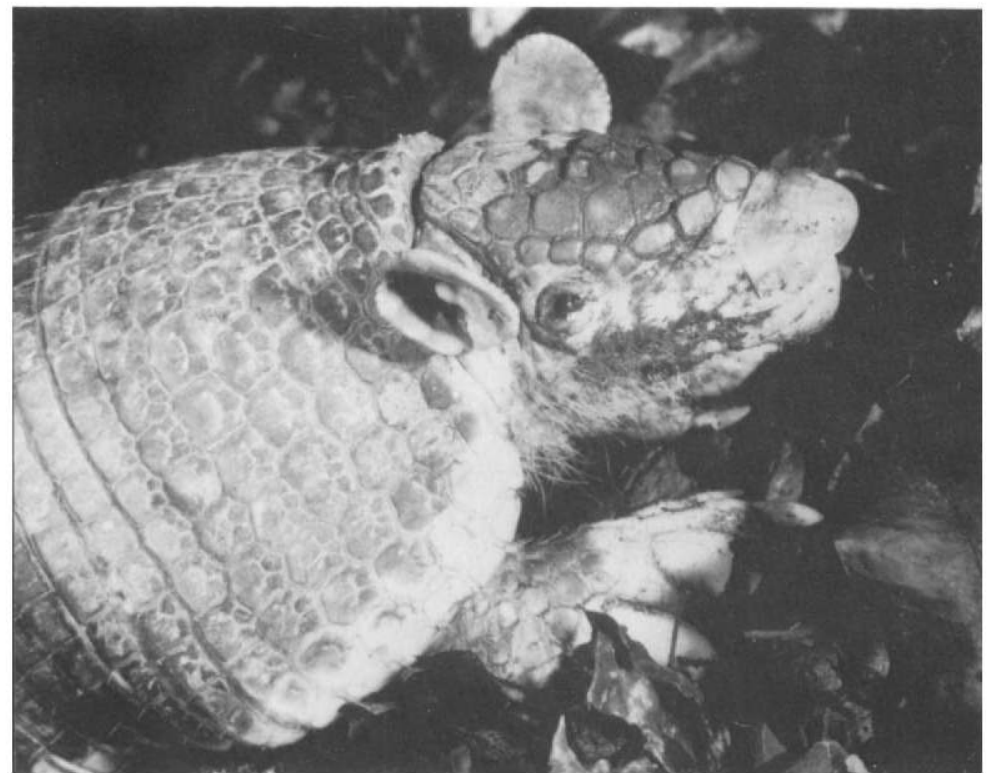

Fig. 82. Central American five-toed armadillo, Cabassous centralis. Photo by R. $K$. LaVal.

\section{Dasypus novemcinctus Nine-banded Armadillo, Cusuco}

Nine-banded armadillos are the most widely distributed xenarthrans, occurring from the southeastern United States to southeastern Brazil and northeastern Argentina (Wetzel 1982; Fig. 83). The subspecies Dasypus novemcinctus fenestratus is found throughout Costa Rica, except at higher elevations.

Armadillos have been noted at La Selva on many occasions. They have become so abundant in recent years that they can be seen nearly every evening. An adult female and her litter of four half-grown young were sighted by us on several occasions in August 1988. One armadillo was observed by us in March 1986 at $200 \mathrm{~m}$. Pringle et al. (1984) reported sighting an armadillo along the trail east of the Quebrada Cantarrana base camp in January 1983.

The biology and distribution of Dasypus novemcinctus recently was reviewed by McBee and Baker (1982) and Wetzel (1983, 1985).

Specimen examined (1)-4 mi N of Barva, Hwy. 9 [1 male, LACM]. 
Fig. 83. Ninebanded armadillo, Dasypus novemcinctus. Photo by $B$. $L$. Clauson.

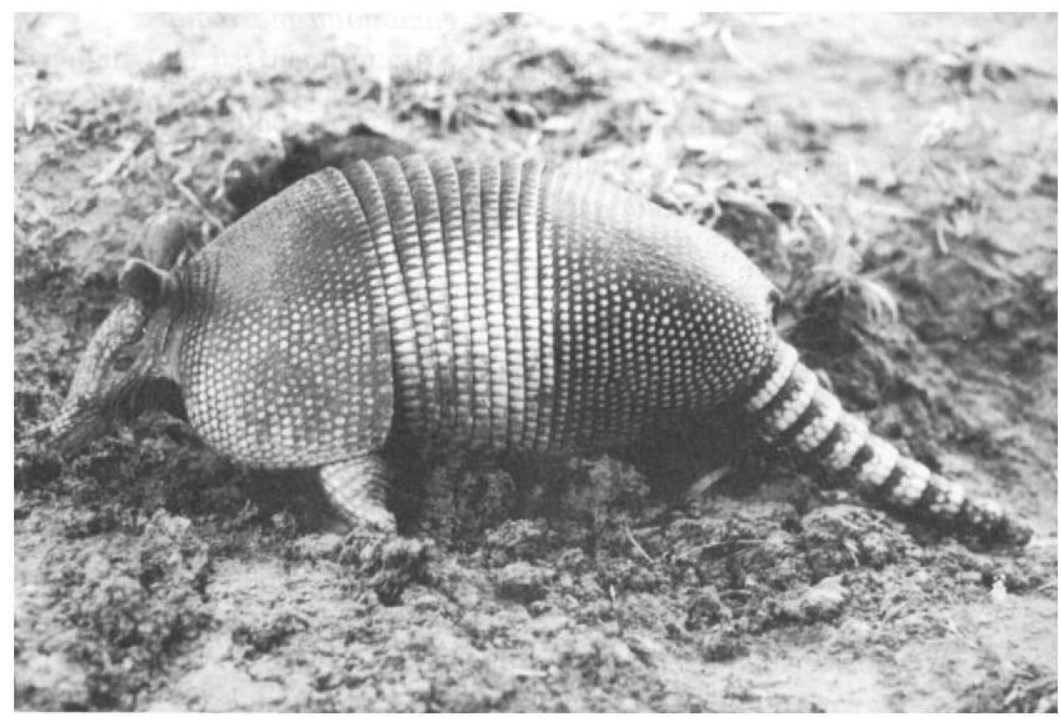

Family Myrmecophagidae

Cyclopes didactylus

Silky Anteater, Serafín de Platanar or Tapacara

Silky anteaters are known from southern Mexico to northern South America (Fig. 84). The subspecies Cyclopes didactylus dorsalis is found throughout the tropical humid zone of Costa Rica up to about $1,500 \mathrm{~m}$.

Silky anteaters have been observed on 11 occasions at La Selva. As with the sloths, we believe that they are present in the lower elevations of Parque Nacional Braulio Carrillo. However, there are no records from Braulio Carrillo, probably because they are difficult to observe. The biology of silky anteaters recently was reviewed by Montgomery (1983b).

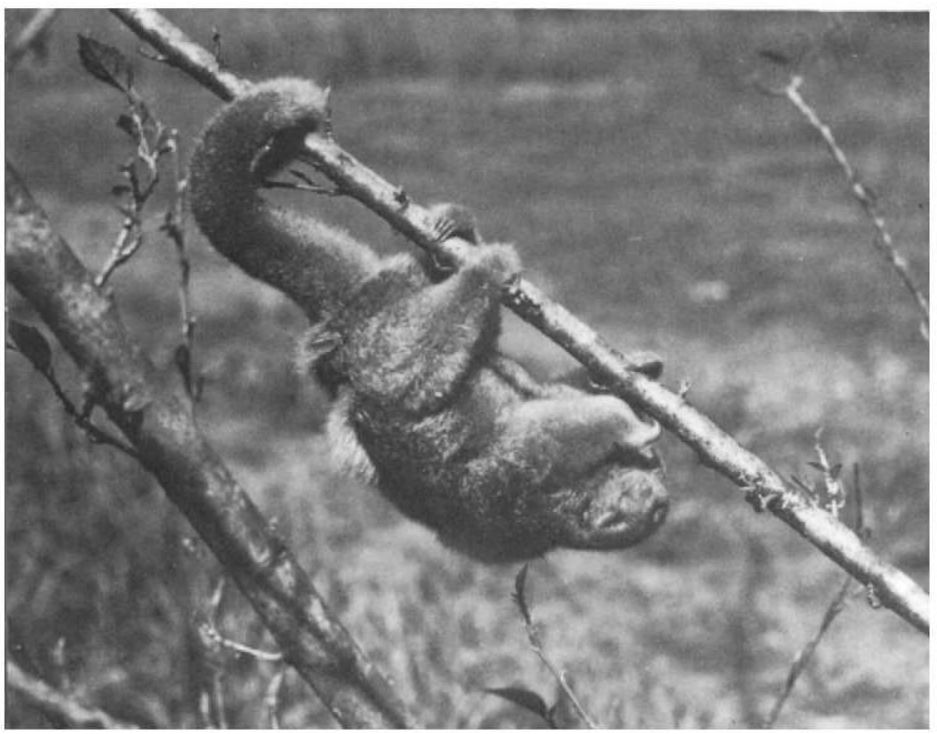

Fig. 84. Silky anteater, Cyclopes didactylus. Photo by $R$. $W$.

McDiarmid 


\section{Tamandua mexicana \\ Northern Tamandua, Oso Hormiguero}

Northern tamanduas are found from southern Mexico to northwestern Venezuela, western Colombia, western Ecuador, and western Peru (Fig. 85). The subspecies Tamandua mexicana chiriquensis occurs throughout Costa Rica from sea level to $1,500 \mathrm{~m}$.

Tamanduas commonly are encountered at La Selva where they have been seen as lone individuals year round. Many observations of these animals were during the day when they were active. A lone juvenile tamandua was seen at La Selva on 20 April 1988. An adult female was captured alive on 17 April 1986 (3 km $\mathrm{S}, 11.5 \mathrm{~km}$ E of San Miguel, $1,400 \mathrm{~m}$ ) and released after being photographed. A second tamandua was spotted during midday on 27 March as it traveled near the $300-\mathrm{m}$ base camp, about $10 \mathrm{~km} \mathrm{~S}, 9.5 \mathrm{~km} \mathrm{~W}$ of Puerto Viejo. It appeared to be an adult, but no attempt was made to capture the animal. Pringle et al. (1984) reported a tamandua in January 1983 on the trail east of the Quebrada Cantarrana base camp.

Additionally, an adult female was found dead on Route 9 just northeast of La Virgen, $180 \mathrm{~m}$, on 8 June 1982 by Timm. The biology of tamanduas in Costa Rica was reviewed recently by Lubin (1983).

Specimen examined (1)-La Virgen, $180 \mathrm{~m}$ [ 1 female, FMNH].

\section{ORDER LAGOMORPHA}

\section{Family Leporidae \\ Sylvilagus brasiliensis \\ Forest Rabbit or Forest Cottontail, Conejo}

Forest rabbits occur from the eastern and southern lowlands of Mexico through Central America and South America to northern Argentina and southern Brazil (Fig. 86). In Costa Rica the subspecies Sylvilagus brasiliensis gabbi is found in the Caribbean lowlands (Diersing 1981).

Forest rabbits have been recorded in the log book at La Selva on only 13 occasions in the early 1980 's; however, they are now seen frequently in the station clearing and along the Sura trail. Also, it was not uncommon to see forest rabbits in the clearings around the laboratory buildings in 1977 and 1978. Forest rabbits are more common in the successional plots and in clearings at La Selva than in primary forest. Hoth (in litt.) observed at night a single pair for a period of 2 weeks in August 1987. During that time he saw several copulations. A 2-m long fer-delance (Bothrops asper) captured on 5 July 1978, in disturbed habitat at La Selva, contained an adult $S$. brasiliensis (Findley, in litt.). In January 1983, forest rabbits occasionally were seen in grass along the trail east of the Cantarrana base camp (Pringle et al. 1984).

Specimens examined (7)-Puerto Viejo, Río Sarapiquí, $300 \mathrm{ft}$ [5 males, 1 female, UMMZ]; $1.7 \mathrm{mi} S$ of Puerto Viejo [1 male, LACM]. 


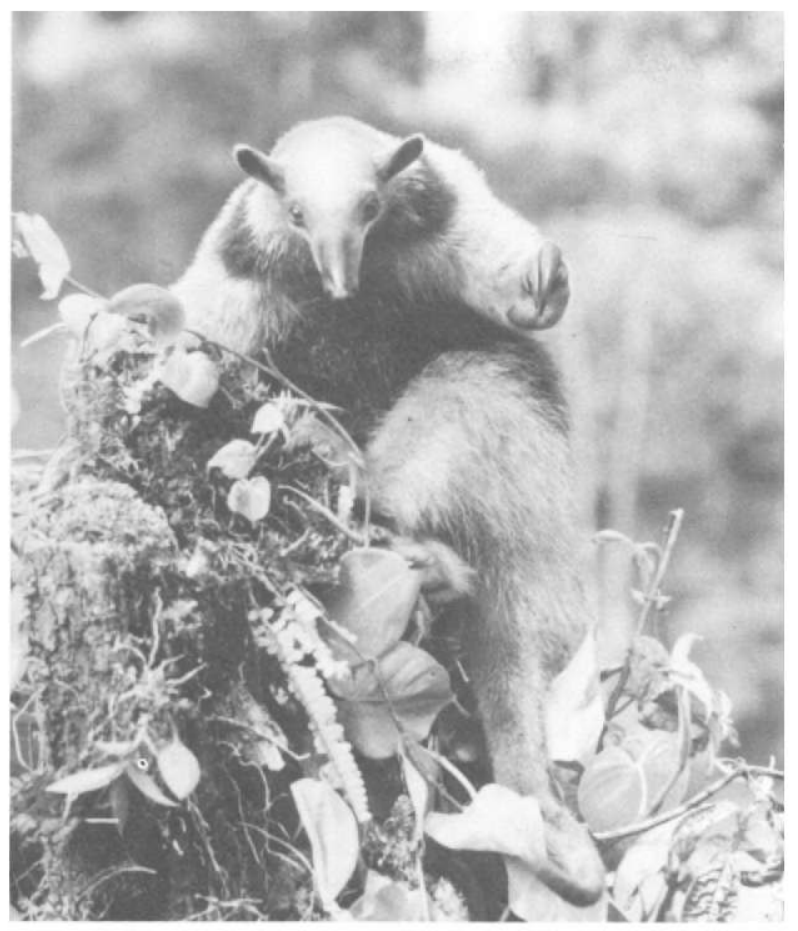

\section{Fig. 85. Northern tamandua, Tamandua mexicana. Photo by B. L. Clauson.}

Fig. 86. Forest rabbit, Sylvilagus brasiliensis. Photo by J. Hoth.

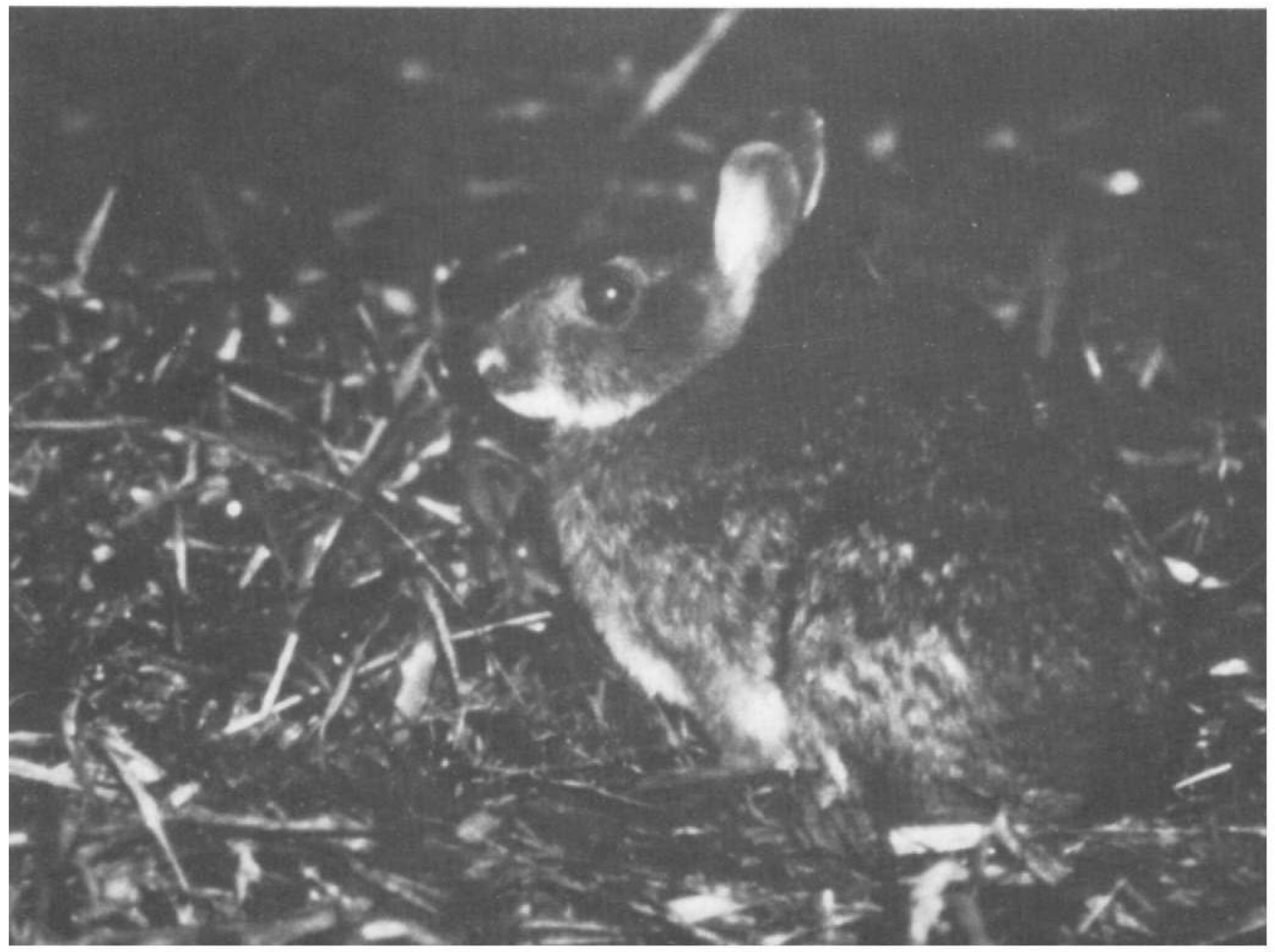




\section{Sylvilagus dicei \\ Dice's Cottontail, Conejo}

Dice's cottontail is restricted to elevations above $1,100 \mathrm{~m}$ in the Cordillera de Talamanca of Costa Rica and adjacent west-central Panama. There are no recognized subspecies of Sylvilagus dicei. Sylvilagus dicei originally was described by Harris (1932) based on specimens from El Copey de Dota in the Cordillera de Talamanca. Most subsequent authors have followed Hershkovitz (1950) in regarding dicei as a subspecies of $S$. brasiliensis; however, Diersing (1981) recently demonstrated that this is a separate species of cottontail rabbit.

We observed at night a single cottontail rabbit on a trail near the $2,600-\mathrm{m}$ base camp. Although there are no specimens of cottontail rabbits from Parque Nacional Braulio Carrillo, based on their known distribution and systematics, rabbits at lower elevations are probably $S$. brasiliensis and those at higher elevations probably are $S$. dicei. Dice's cottontails are an important component of the diet of coyotes (Canis latrans) in the Costa Rican highlands (Vaughan and Rodriguez 1986).

\section{ORDER RODENTIA}

\section{Family Sciuridae \\ Microsciurus alfari Alfaro's Pygmy Squirrel, Ardilla or Chiza}

Alfaro's pygmy squirrels are found from southern Nicaragua to northwestern Colombia. Three subspecies are known from lower and middle elevations of northeastern Costa Rica: Microsciurus alfari alfari (the subspecies occurring at La Selva), $M$. a. alticola, and $M$. a. septentrionalis. A fourth subspecies, $M$. a. browni, is found in the southwestern lowlands.

Pygmy squirrels have been noted at La Selva on 12 occasions; on 4 observations, 2 squirrels were seen together and the remaining 8 observations were of lone individuals. In February 1985, a pygmy squirrel was seen feeding on the fruit of Dipteryx panamensis, a common canopy tree at La Selva. A semiplumbeous hawk (Leucopternis semiplumbea) was seen diving at, but missing, a pygmy squirrel in April 1982. In January 1987, we watched 2 individuals as they spent $10 \mathrm{~min}$ moving about on lianas attached to a huge Ceiba pentandra. They descended and crossed the ground to an adjacent tree. Pygmy squirrels were observed by the 1983 Zona Expedition (Pringle et al. 1984).

Specimens examined (2)-Río Sarapiquí, Puerto Viejo, $300 \mathrm{ft}$ [1 male, UMMZ]; La Hondura, Province San José [1, UMMZ; Harris 1943].

\section{Sciurus granatensis \\ Tropical Red-tailed Squirrel, Ardilla or Chiza}

Tropical red-tailed squirrels range from Costa Rica south to Ecuador and Venezuela (Fig. 87). Two subspecies are now recognized from Costa Rica: Sciurus granatensis hoffmanni in the central highlands and $S . g$. chiriquensis in the 


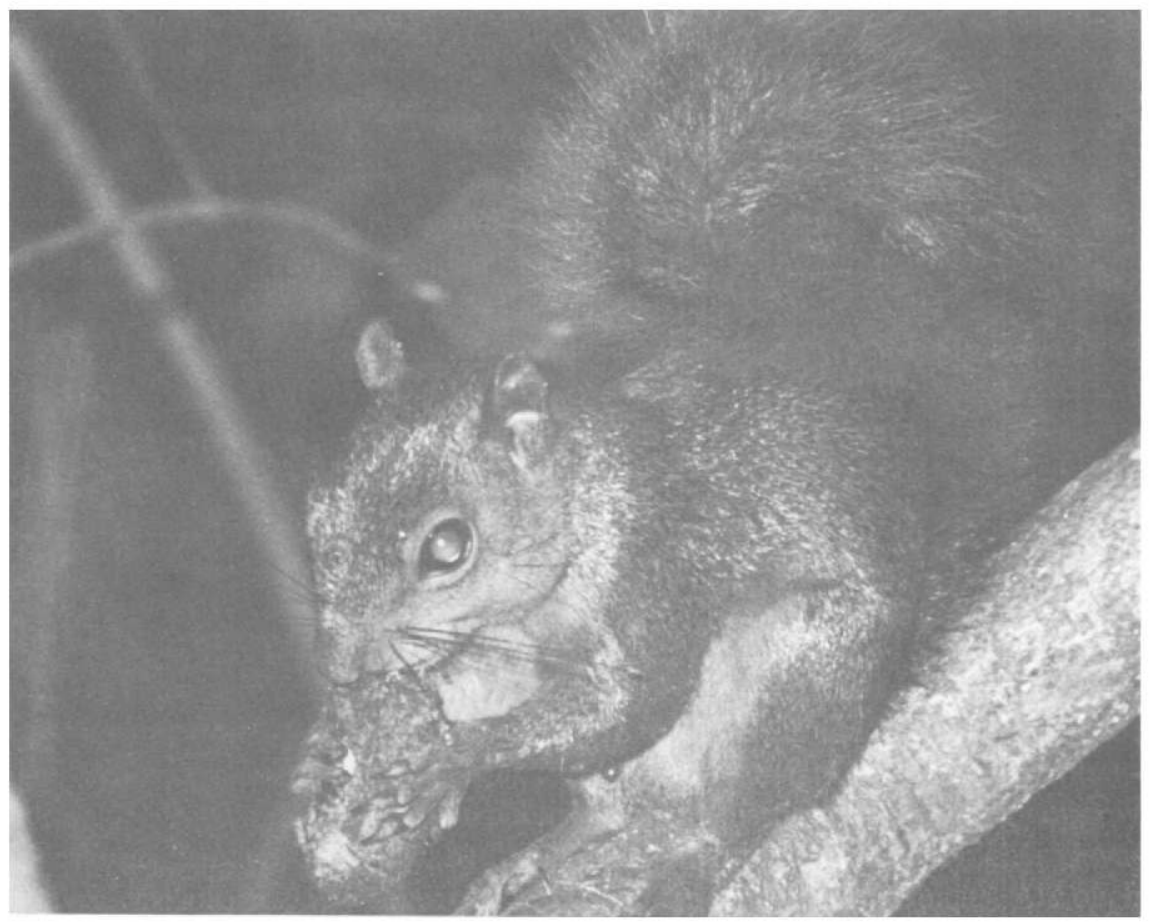

Fig. 87. Tropical red-tailed squirrel, Sciurus granatensis. Photo by $C$. Thorington.

surrounding lower elevations including the La Selva area. These squirrels occur from sea level to about $1,500 \mathrm{~m}$.

Sciurus granatensis was seen on several occasions within Parque Nacional Braulio Carrillo at elevations ranging from 100 to $860 \mathrm{~m}$. In the forest near the $300-\mathrm{m}$ base camp, one individual was observed on several days in succession. We have observed red-tailed squirrels on several occasions at La Selva. In the mammal logbook at La Selva there are several records listed of medium-sized Sciurus identified as $S$. deppei. We suspect that most, if not all, of these observations are actually $S$. granatensis.

In Panama, $S$. granatensis eats a wide variety of plants, but the large, nutlike fruits of three species, Astrocaryum standleyanum, Dipteryx panamensis, and Scheelea zonensis, make up most of the diet. The reproductive season of tropical red-tailed squirrels is strongly correlated to the seasonal availability of these three preferred fruits. Adult females were found to have an average of two litters per year and a mean of 1.9 young per litter (Glanz et al. 1982). The biology of these squirrels was reviewed recently by Heaney (1983) and Nitikman (1985).

Specimens examined (3)-Puerto Viejo, Río Sarapiquí, $300 \mathrm{ft}$ [1 female, UMMZ]; San José de la Montaña [2, UNA].

Additional record (1)-2 mi SE of Cariblanco [1 male, MVZ]. 


\section{Sciurus variegatoides \\ Variegated Squirrel, Ardilla or Chiza}

Variegated squirrels are found from southern Mexico to Panama (Fig. 88). In Costa Rica, as many as eight subspecies of Sciurus variegatoides have been reported (Hall 1981); however, the color patterns of this squirrel are quite variable geographically and its subspecific taxonomy is in need of revision. The subspecies of variegated squirrel thought to be represented in northeastern Costa Rica is Sciurus variegatoides thomasi. Variegated squirrels are often abundant at low and middle elevations. We have found them as high as $1,850 \mathrm{~m}$.

Variegated squirrels have been recorded on only 10 occasions in the mammal logbook at La Selva. We saw one near the El Sura bridge in January 1987.

Specimens examined (2)-Barva, San Miguel de la Montaña, 1,800 m [1 male, $\mathrm{KU}$; 1 male, UNA].

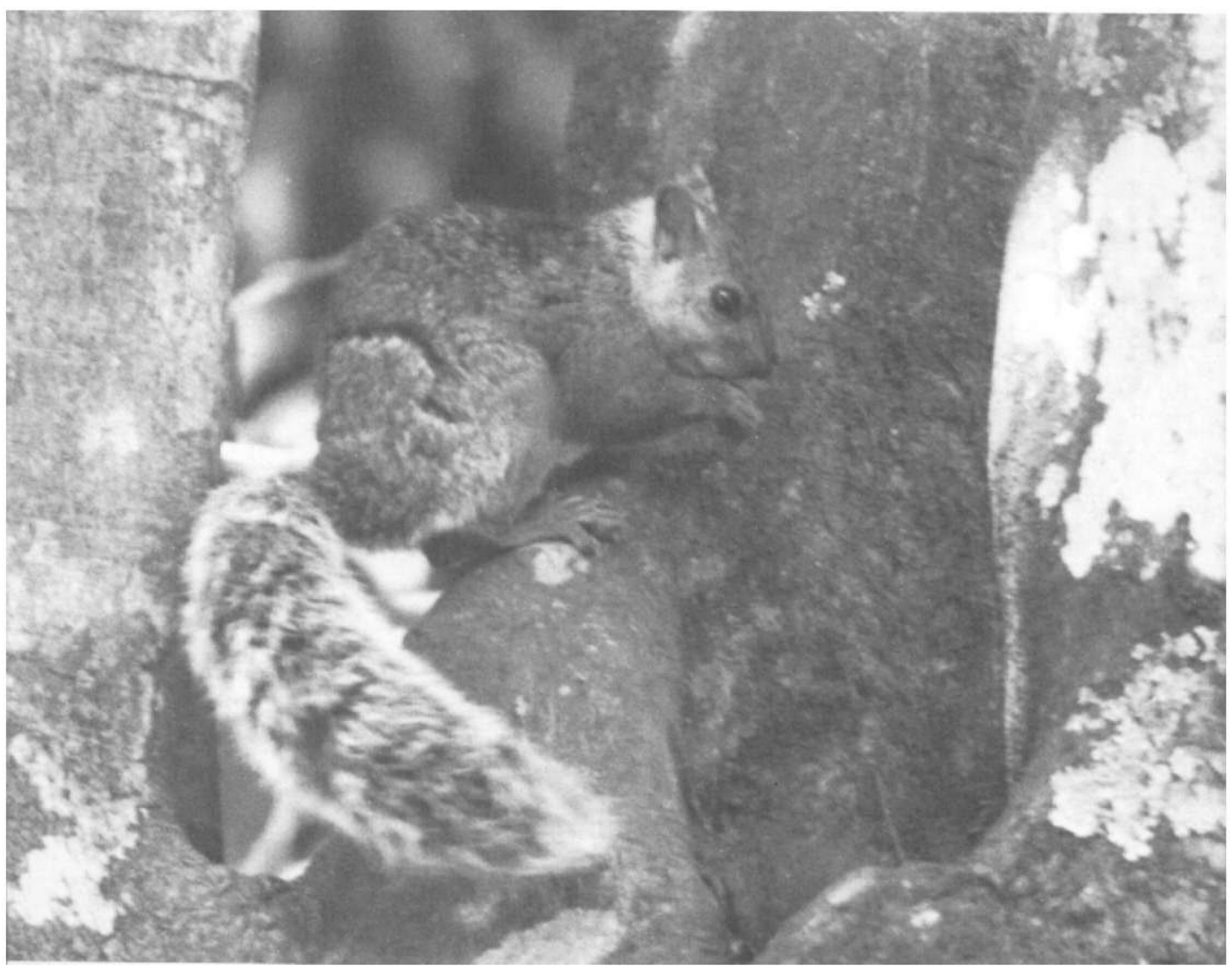

Fig. 88. Variegated squirrel, Sciurus variegatoides. Photo by R. M. Timm. 


\section{Family Geomyidae \\ Orthogeomys cherriei \\ Cherrie's Pocket Gopher, Taltusa}

Cherrie's pocket gopher, Orthogeomys cherriei, previously was thought to be restricted to low elevations of central and northern Costa Rica; however, it has been documented recently that this species occurs in a broad elevational band (from 50 to $1,450 \mathrm{~m}$ ) north and east of the Cordillera Central and north and west of the Cordillera de Tilaran in northern Costa Rica (Hafner and Hafner 1987; Fig. 89). Although there are no specimens of pocket gophers from La Selva or Parque Nacional Braulio Carrillo, we know that they occur in these regions and we suspect that the species is $O$. cherriei. Orthogeomys cherriei is abundant in the vicinity of Santa Clara, Limón Province, where it does considerable damage to bananas. Pocket gophers are difficult to locate in forests; we suspect that in lowland forests they only occur in the more fertile soils that have little rock and are fairly well drained. Pocket gophers are often more abundant in disturbed habitats than they are in pristine forests.

Pocket gophers destroyed L. R. Holdridge's original plantation of Para rubber trees, Hevea brasiliensis (Euphorbiaceae), at La Selva in the late 1950's. Hartshorn (in litt.) has seen the destruction of the basal meristem of young Welfia georgii palms by pocket gophers in primary forest at La Selva. Large populations of pocket gophers in the Puerto Viejo region cause severe damage to agricultural crops, especially bananas, platano, and yuca, with some farmers reporting as much as a $50 \%$ crop loss (Sisk and Vaughan 1984).

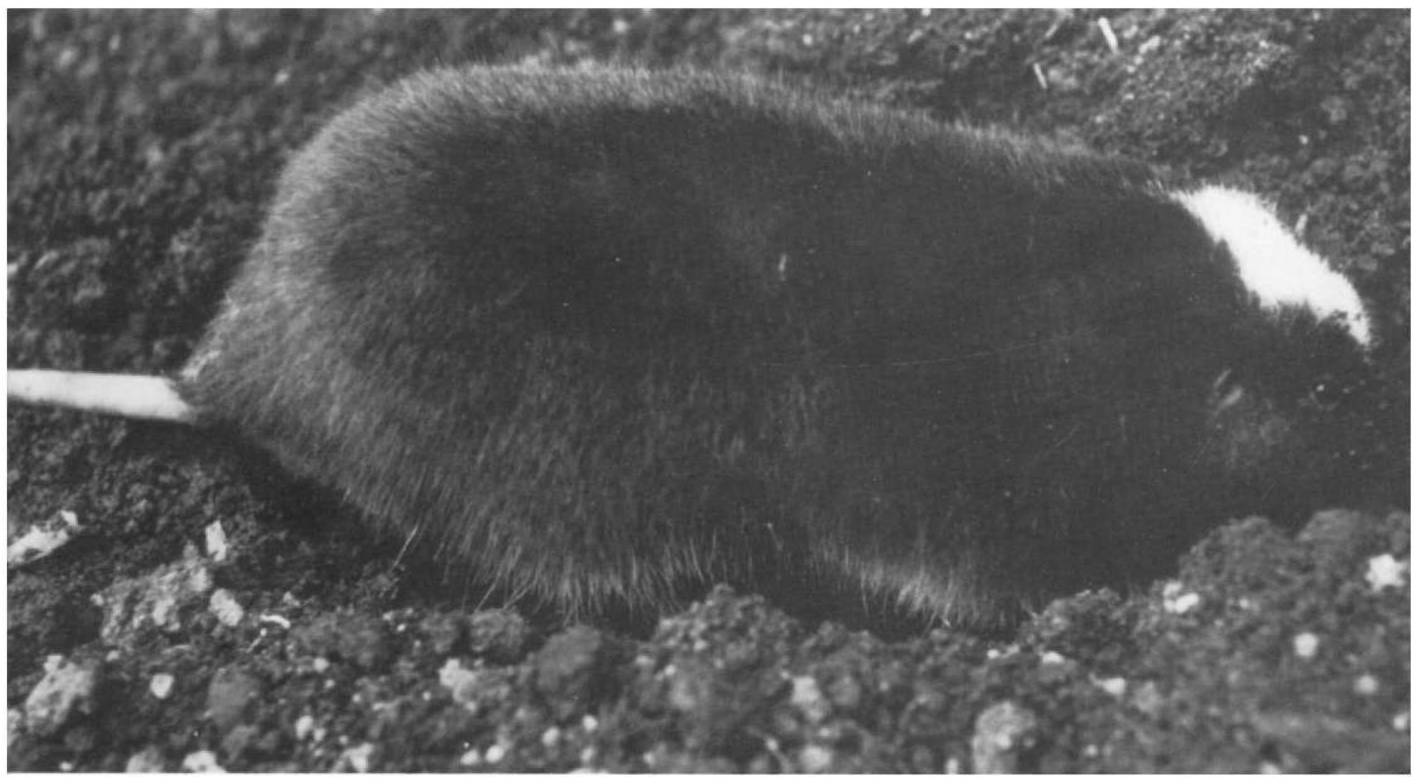

Fig. 89. Cherrie's pocket gopher, Orthogeomys cherriei. Photo by $R$. K. LaVal. 


\section{Orthogeomys heterodus Variable Pocket Gopher, Taltusa}

The variable pocket gopher, a species endemic to Costa Rica, is known from the mid- and high elevations of the Cordillera Central and Cordillera de Talamanca (Fig. 90). Three subspecies of Orthogeomys heterodus currently are recognized from Costa Rica, but we know little of its systematics, distribution, or ecology. The subspecies $O$. $h$. cartagoensis occurs on the northeastern Caribbean slope and in the adjacent central valley. Although there are no specimens of $O$. heterodus from Braulio Carrillo, this species is known from just outside the park near Concepción de San Rafael de Heredia and elsewhere in Heredia Province, and we suspect that it occurs in the park also.

In a study of several aspects of the natural history of $O$. heterodus near Concepción, Sisk and Vaughan (1984) found that variable pocket gophers had extensive tunnel systems that consisted of three parts: an enlarged central chamber or nest, radiating tunnels that connect the nest with foraging areas, and a network of shallow feeding tunnels. They found multiple foraging areas within the territory, a foraging strategy previously unreported in pocket gophers. Activity periods consisted of short excursions from the nest area to foraging areas, with $90 \%$ of the time spent near the nest. The average home range for two gophers was $237 \mathrm{~m}^{2}$ (Sisk and Vaughan 1984).

Fig. 90. Variable pocket gopher, Orthogeomys heterodus. Photo by N. Woodman.

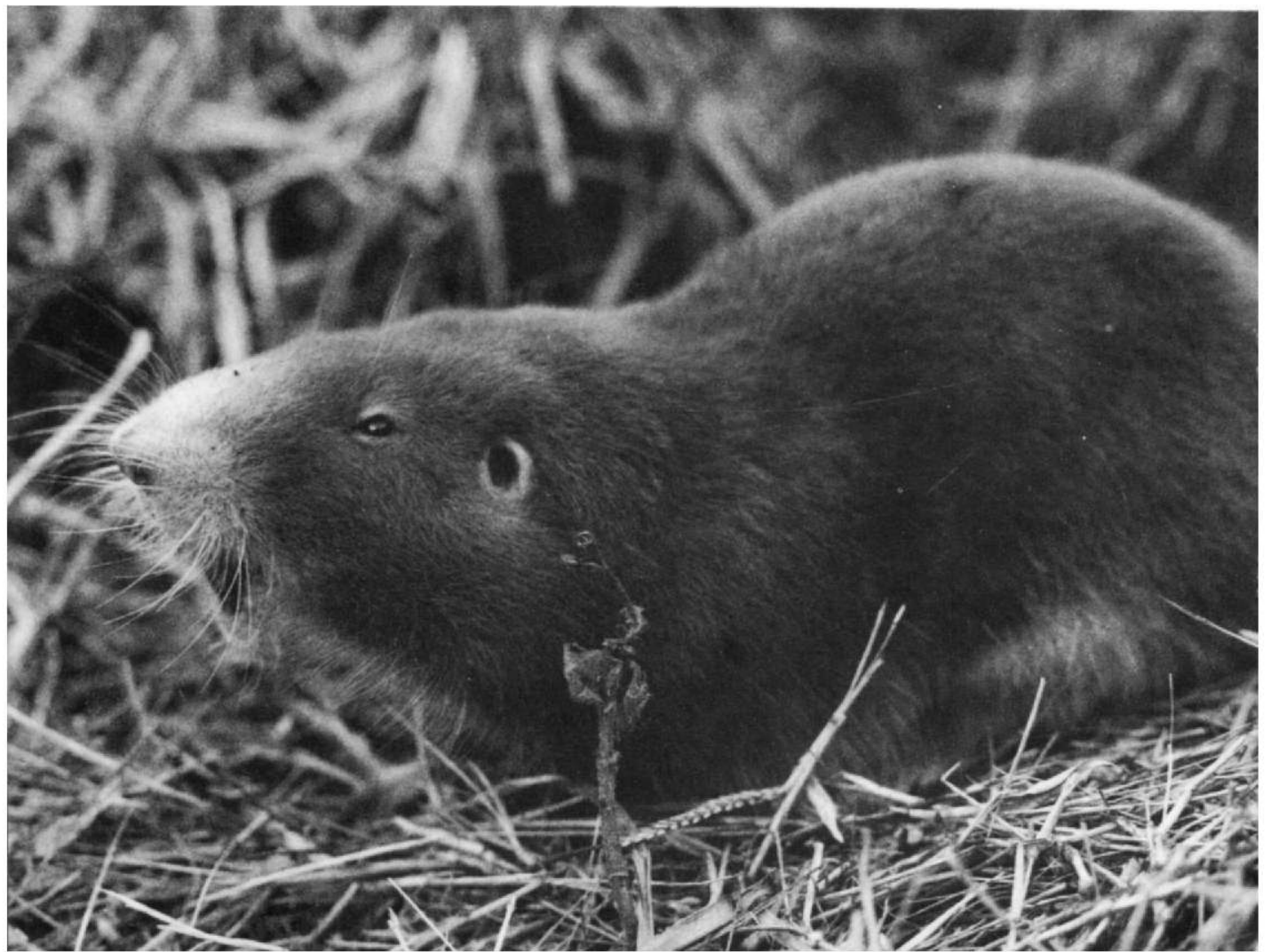




\section{Family Heteromyidae}

\section{Heteromys desmarestianus}

\section{Desmarest's Spiny Pocket Mouse, Ratón Semiespinosa}

Desmarest's spiny pocket mouse is found from extreme southern Mexico to Colombia (Fig. 91). Five subspecies of Heteromys desmarestianus currently are recognized from Costa Rica; the race at La Selva being $H$. $d$. subaffinis. It is found from sea level to high elevation cloud forest and may be extremely abundant locally (Fleming 1983b).

Heteromys desmarestianus is the most abundant forest floor rodent at La Selva and is found in a wide array of forested habitats (Fleming 1974a,b, 1977a,b). However, it is uncommon or absent in the successional plots at La Selva. All females weighing more than $66 \mathrm{~g}$ were pregnant in April 1986 (Table 1). Mean testes length and width for eight adult males was $19.8 \times 13.1 \mathrm{~mm}$. Spiny mice were found carrying seeds of the following plants in their cheek pouches: Euterpe macrospadix, Geonoma sp., Iriartea gigantea (Palmae), and Meliosma sp. (Sabiaceae). Bushmasters (Lachesis muta) are abundant at La Selva and often are found coiled near Welfia palms, the preferred food of spiny mice (Fleming and Brown 1975). It is likely that spiny mice constitute one of the principal food items of bushmasters.

We found one species of sucking louse, Fahrenholzia ferrisi (Hoplopleuridae), to be abundant on $H$. desmarestianus. In April 1986, we found all life cycle stages including eggs, first, second, and third instars, and adults, primarily on the dorsal surface of hosts.

Fig. 91. Desmarest's spiny pocket mouse, Heteromys desmarestianus. Photo by B. L. Clauson.

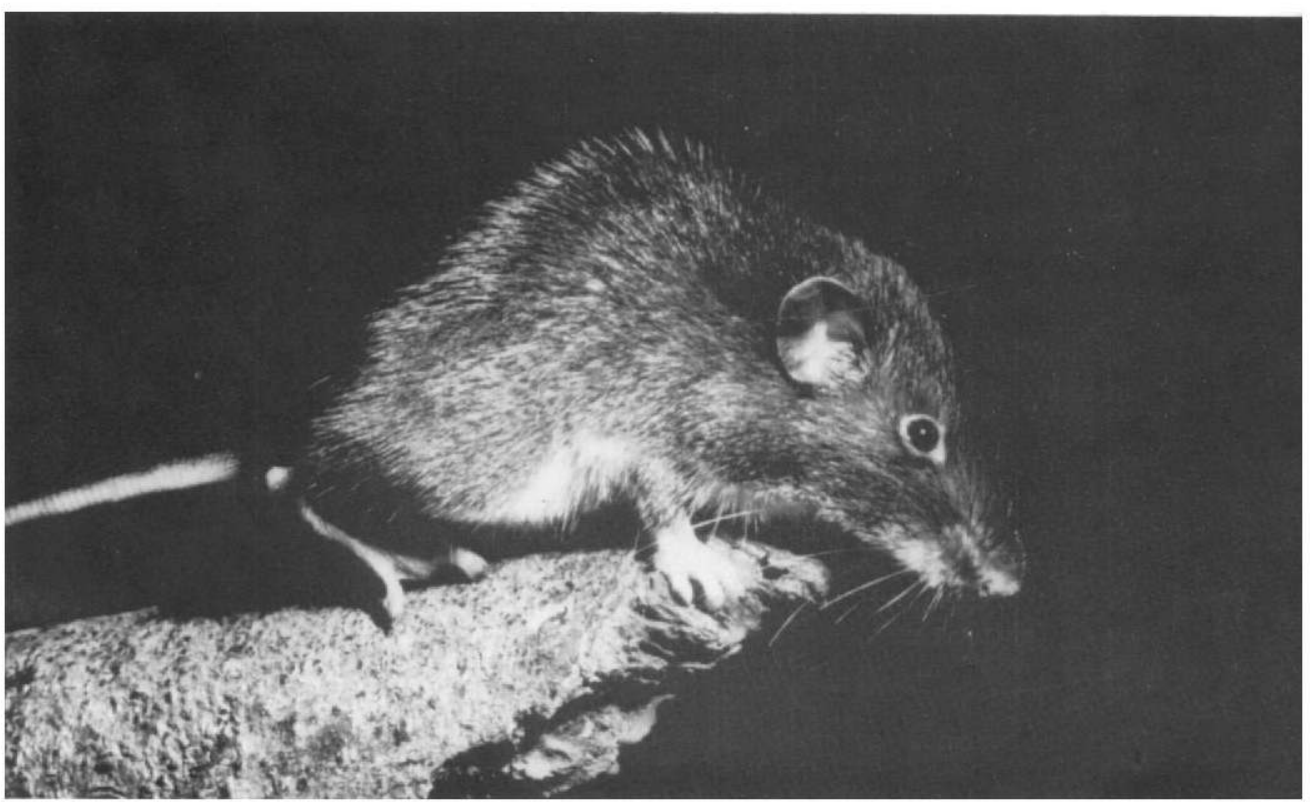


Table 1. Reproductive characteristics of five adult (weight $>66 \mathrm{~g}$ ) female Heteromys desmarestianus from Heredia Province, Costa Rica. ${ }^{a}$

Date of

capture

Reproductive characteristics

29 March 1986

3 embryos $\times 12 \mathrm{~mm}(2 \mathrm{~L}-1 \mathrm{R})$, lactating

30 March 1986

pregnant female, mammae enlarged; released

5 April 1986

2 embryos $\times 22 \mathrm{~mm}(1 \mathrm{~L}-1 \mathrm{R})$ plus 1 resorbing embryo

5 April 1986

3 embryos $\times 23 \mathrm{~mm}(1 \mathrm{~L}-2 \mathrm{R})$

8 April 1986

uterus enlarged, no embryos or placental scars

${ }^{a}$ Eight females weighing between 45 and $66 \mathrm{~g}$ showed no sign of reproductive activity. All females weighing more than $66 \mathrm{~g}$ were reproductively active.

A tineid moth, Amydria selvae, phoretic on $H$. desmarestianus, was described by Davis et al. (1986) from La Selva. Only females of $A$. selvae were found on spiny pocket mice; no males were collected. All specimens were taken in July 1984. Heteromys desmarestianus was trapped in both lowland and highland localities and at La Selva in late August and September, but no additional moths were found (Davis et al. 1986). We examined $47 \mathrm{H}$. desmarestianus captured from 280 to 1,520 m elevation in late March and April 1986 in Parque Nacional Braulio Carrillo but found no tineids. Nor were any tineids found on $120 \mathrm{H}$. desmarestianus caught near Monteverde, Puntarenas Province at elevations ranging from 1,380 to $1,860 \mathrm{~m}$ in May 1986. Ticks found on $\boldsymbol{H}$. desmarestianus included four adult female Lxodes venezuelensis. This represents the first record of this tick on $H$. desmarestianus.

Specimens examined (255)-Finca La Selva, $3 \mathrm{~km} \mathrm{~S}$ of Puerto Viejo [1 male, 2 females, KU; 9 males, 5 females, LACM; 101 males, 99 females, UMMZ]; Puerto Viejo, Río Sarapiquí [1 female, KU]; $1.7 \mathrm{mi} \mathrm{S}$ of Puerto Viejo [1 male, LACM]; $3.2 \mathrm{mi} \mathrm{S}$ of Puerto Viejo [1 female, LACM]; $11 \mathrm{~km} \mathrm{S,} 4.5 \mathrm{~km} \mathrm{~W}$ of Puerto Viejo, 280, 325, 340, 365, and $369 \mathrm{~m}$ [ 2 males, 8 females, FMNH; 1 male, UNA]; $1 \mathrm{~km} \mathrm{S,} 11.5 \mathrm{~km}$ E of San Miguel, 680, 700, $710 \mathrm{~m}$ [ 6 males, 8 females, FMNH; 1 male, 1 female, UNA]; $3.5 \mathrm{~km} \mathrm{~S}, 11.5 \mathrm{~km}$ E of San Miguel, $1,000 \mathrm{~m}$ [ 3 males, 2 females, FMNH]; $9 \mathrm{~km} \mathrm{S,} 11.5 \mathrm{~km}$ E of San Miguel, $1,520 \mathrm{~m}$ [ $1 \mathrm{male}$, 2 females, FMNH].

\section{Family Muridae}

Nyctomys sumichrasti

\section{Sumichrast's Vesper Rat, Ratón}

Sumichrast's vesper rat is found from Mexico to eastern Panama (Fig. 92). Three subspecies of Nyctomys sumichrasti occur in Costa Rica, $N$. s. costaricensis along the Pacific slopes, $N$. s. nitellinus in the southeast, and $N$. s. venustulus in the northeast. It is found from sea level to $1,500 \mathrm{~m}$. Ecology and morphological variation in vesper rats in Nicaragua were reported by Genoways and Jones (1972). 


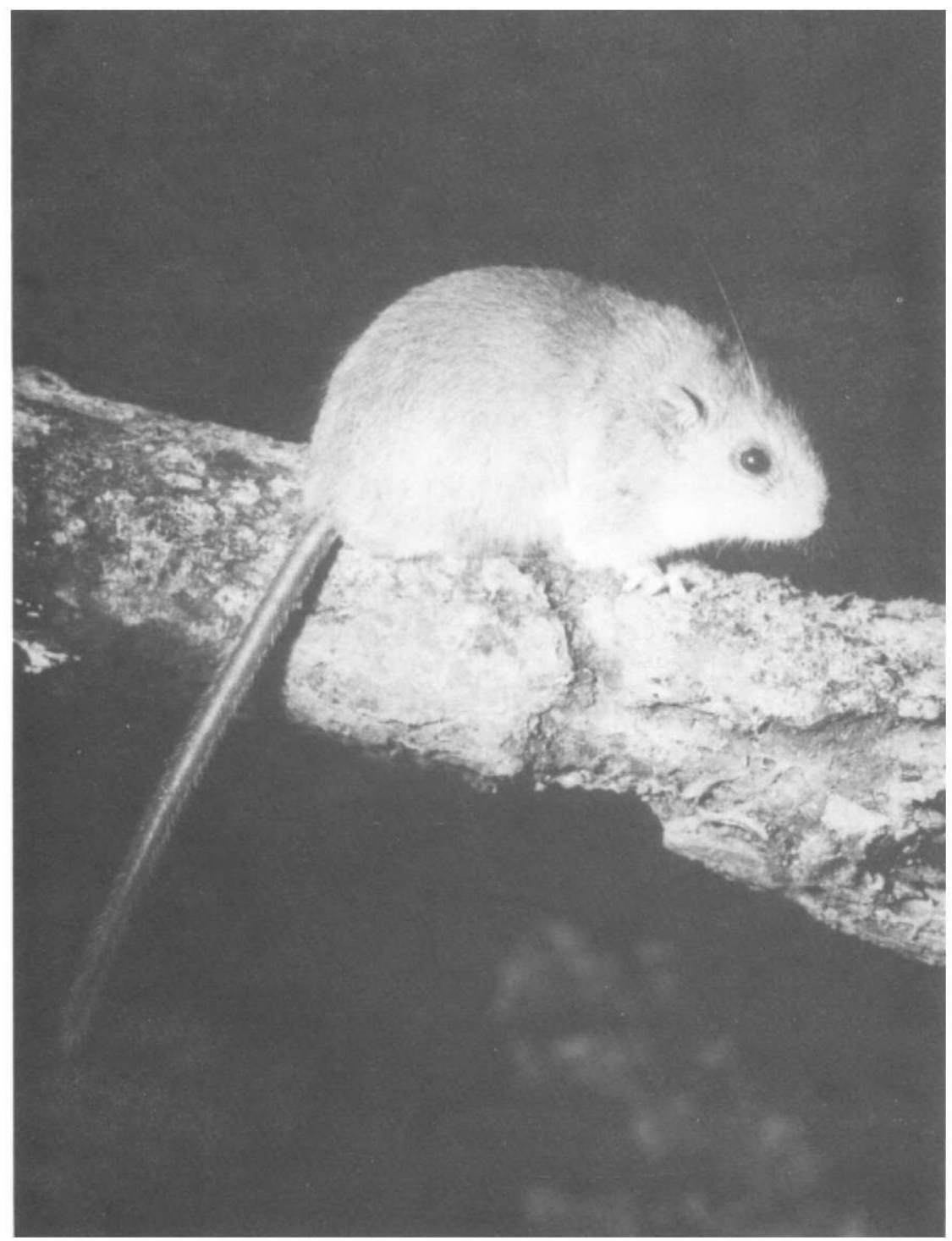

Fig. 92. Sumichrast's vesper rat, Nyctomys sumichrasti. Photo by B. L. Clauson.

Vesper rats may be common in the forest at La Selva, but they are seldom observed because of their nocturnal, arboreal habits. Fleming (1973) reported catching a Sumichrast's vesper rat at La Selva in primary forest. An adult and subadult were collected by Findley in the laboratory buildings in July 1974. An adult male captured on 7 August 1971 had fully scrotal testes measuring $14 \times 7 \mathrm{~mm}$.

Specimens examined (3)-Finca La Selva, $3 \mathrm{~km} \mathrm{~S}$ of Puerto Viejo [1 female, KU; 2 sex?, MSB]; 7.3 mi SE of Puerto Viejo [1 male, TTU]. 


\section{Oryzomys albigularis \\ Tomes' Rice Rat, Ratón Arrocera}

Tomes' rice rat occurs at high elevations in Costa Rica, Panama, Colombia, and Venezuela (Fig. 93). The Central American populations are restricted to elevations above $1,000 \mathrm{~m}$ in Costa Rica and the adjacent Chiriquí mountains of western Panama. A single subspecies, Oryzomys albigularis devius, is recognized in Costa Rica and western Panama. This northern disjunct population of $O$. albigularis is isolated by the Panamanian lowlands from the populations in extreme eastern Panama, Colombia, and Venezuela. Gardner (1983b) considered this disjunct population to be a distinct species, Oryzomys devius.

Tomes' rice rat previously was thought to be restricted in Costa Rica to the Cordillera Central and Cordillera de Talamanca. However, we recently have found this distinctive species to be abundant in the cloud forests above Monteverde in Puntarenas Province at 1,740 to $1,780 \mathrm{~m}$, thus extending its known range into the Cordillera de Tilaran.

We observed Tomes' rice rat at two localities in Braulio Carrillo at elevations of $1,000 \mathrm{~m}$ and $2,050 \mathrm{~m}$. They appear to be restricted to undisturbed forests. We suspect that the species is widespread and common in appropriate habitats. An adult female collected on 28 April carried three embryos (all in the right uterine horn) with crown-rump lengths of $28 \mathrm{~mm}$. Four adult males had testes that measured $15 \times 9 \mathrm{~mm}, 13 \times 9 \mathrm{~mm}, 13 \times 8 \mathrm{~mm}$, and $13 \times 7 \mathrm{~mm}$ in April. Subadult-sized animals were collected on 5-6 August 1967.

Specimens examined (8)-1.5 mi S of Cariblanco, 2,900 ft [1 male, 2 females, MVZ]; $3.5 \mathrm{~km} \mathrm{S,} 11.5 \mathrm{~km}$ E of San Miguel, $1,000 \mathrm{~m}$ [1 male, FMNH; 1 male, UNA]; $5 \mathrm{~km}$ E of Vara Blanca, 2,050 m [1 male, 1 female, FMNH; 1 male, UNA].

\section{Oryzomys alfari \\ Allen's Rice Rat, Ratón}

Allen's rice rat is found from southeastern Honduras along the Caribbean lowlands to western Panama.

Three specimens of Oryzomys alfari are known from Heredia Province, two of which were captured at La Selva. Fleming (1973) reported that the specimens he collected were caught in live traps baited with corn and placed on the ground.

Specimens examined (2)-Finca La Selva, $3 \mathrm{~km} \mathrm{~S}$ of Puerto Viejo [2 females, UMMZ].

Additional record (1)-32 mi S of Puerto Viejo [1, LACM].

\section{Oryzomys bombycinus Long-whiskered Rice Rat, Ratón Arrocera}

Long-whiskered rice rats are known from only two localities in the eastern Caribbean lowlands of Honduras and Nicaragua and from only a few additional localities in Costa Rica, Panama, western Colombia, and Esmeraldas Province of extreme northwestern Ecuador. The systematics and ecology of this poorly known mouse were reviewed by Pine (1971) and Jones and Engstrom (1986). 


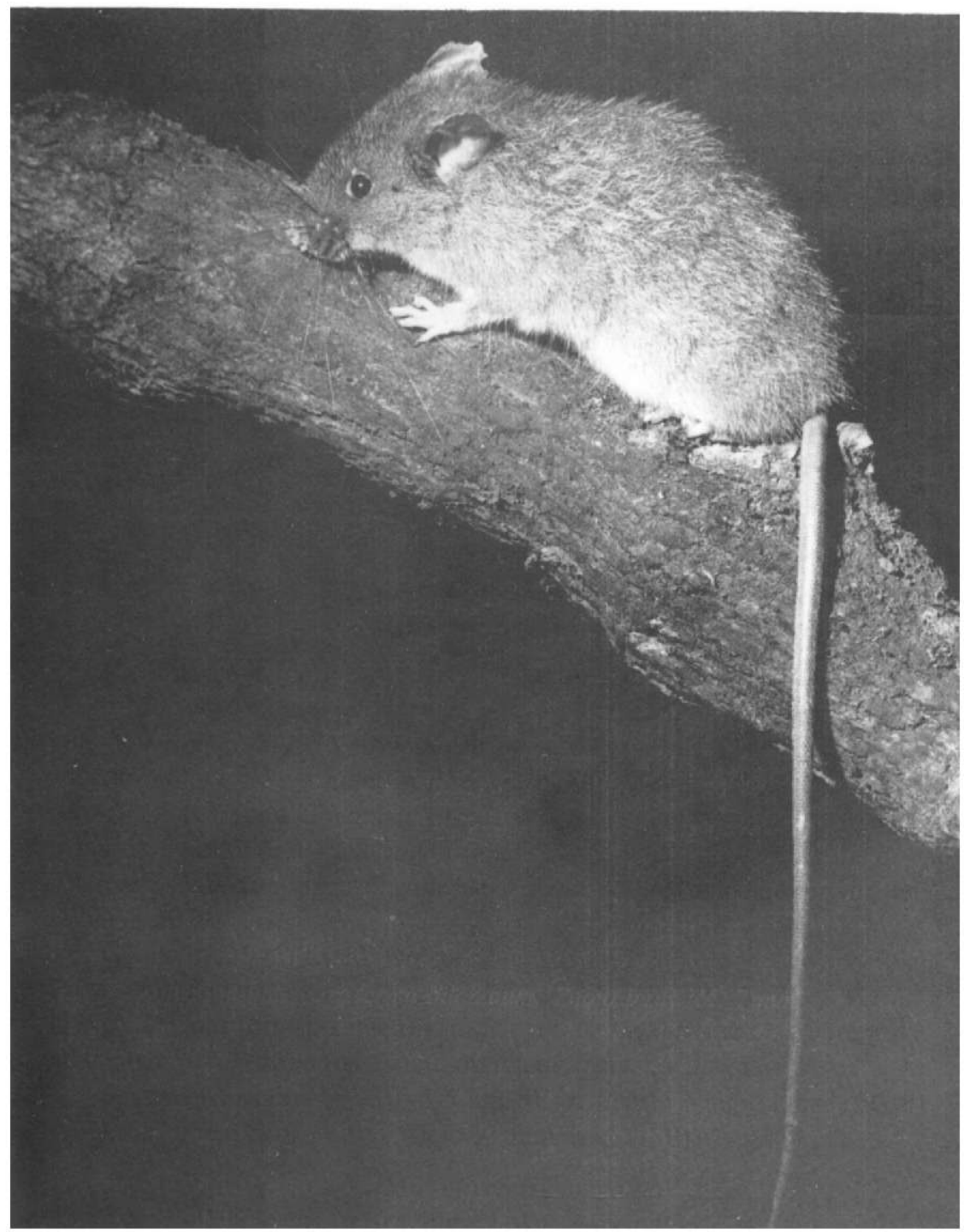

Fig. 93. Tomes' rice rat, Oryzomys albigularis. Photo by B. L. Clauson.

One young adult female captured on 7 April had two newly developed embryos in the right uterine horn. Testes measurements on four males captured in late March and early April were $12 \times 6 \mathrm{~mm}, 10 \times 5 \mathrm{~mm}, 9 \times 5 \mathrm{~mm}$, and $8 \times 6 \mathrm{~mm}$. Specimens examined (7)-Finca La Selva, $3 \mathrm{~km} \mathrm{~S}$ of Puerto Viejo [2 males, UMMZ]; $11 \mathrm{~km} \mathrm{S,} 4.5 \mathrm{~km}$ W of Puerto Viejo, 325 and $340 \mathrm{~m}$ [ 2 males, FMNH; 1 male, UNA]; $1 \mathrm{~km} \mathrm{S,} 11.5 \mathrm{~km} \mathrm{E}$ of San Miguel, $680 \mathrm{~m}$ [1 male, 1 female, FMNH]. 


\section{Oryzomys caliginosus \\ Dusky Rice Rat, Ratón Arrocera}

Dusky rice rats are found from extreme eastern Honduras and Nicaragua to western Ecuador (Fig. 94). In Costa Rica the subspecies Oryzomys caliginosus chrysomelas is found at lower elevations. The biology of dusky rice rats was reviewed recently by Gardner (1983b).

The mean litter size, as judged by counts of embryos and recent placental scars, of three females was 3.0 (Table 2). Mean testes length and width for nine adult male $O$. caliginosus was $10.2 \times 5.8 \mathrm{~mm}$.

A single adult female Ixodes venezuelensis was found on $O$. caliginosus.

Specimens examined (41)-Finca La Selva, $3 \mathrm{~km} \mathrm{~S}$ of Puerto Viejo [1 male, UMMZ]; Parque Nacional Braulio Carrillo [1 male, 1 female, UNA]; Puerto Viejo, Río Sarapiquí, $300 \mathrm{ft}$ [5 males, 4 females, FMNH; 1 male, 1 female, LACM; 1 sex ?, UNA]; $1.7 \mathrm{mi} \mathrm{S}$ of Puerto Viejo [1 male, LACM]; $4.4 \mathrm{mi} \mathrm{S}$ of Puerto Viejo [1 male, LACM]; $5.7 \mathrm{mi} \mathrm{S}$ of Puerto Viejo [1 male, LACM]; $11 \mathrm{~km} \mathrm{~S}$, $4.5 \mathrm{~km} \mathrm{~W}$ of Puerto Viejo, 260 and $280 \mathrm{~m}$ [7 males, 5 females, FMNH; 1 male, 2 females, UNA], $1 \mathrm{~km} \mathrm{~S}, 11.5 \mathrm{~km}$ E of San Miguel, $680 \mathrm{~m} \mathrm{[4}$ males, 4 females, FMNH].

Fig. 94. Dusky rice rat, Oryzomys caliginosus. Photo by B. L. Clauson.

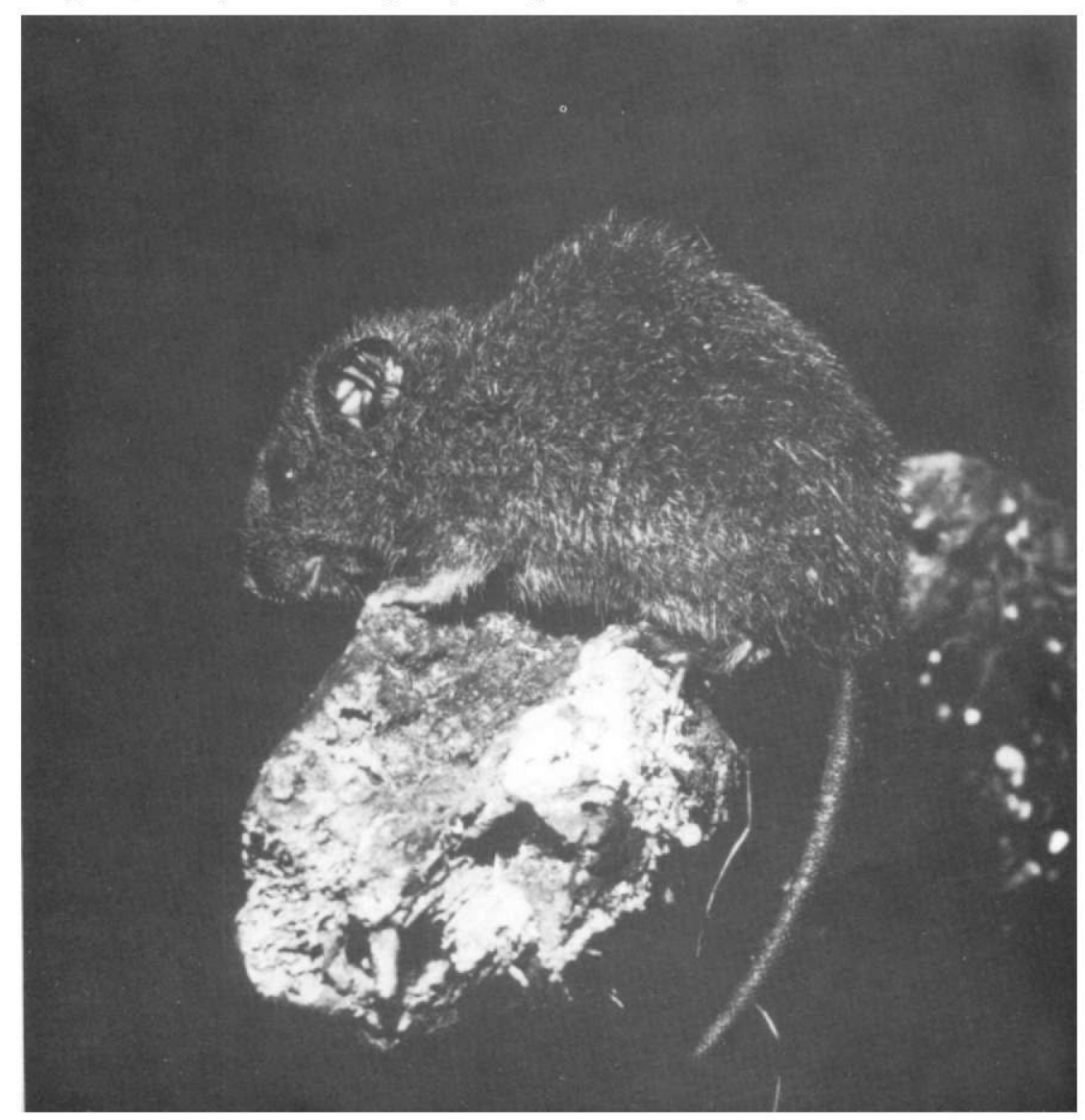


Table 2. Reproductive characteristics of five adult (weight $>36 \mathrm{~g}$ ) female Oryzomys caliginosus from Heredia Province, Costa Rica."

Date of capture

27 March 1986

28 March 1986

30 March 1986

8 April 1986

10 April 1986
Reproductive characteristics

numerous placental scars

3 embryos (1L-2R)

pubic symphysis open, mammae enlarged; released

3 embryos $\times 24 \mathrm{~mm}(1 \mathrm{~L}-2 \mathrm{R})$

3 recent placental scars (2L-1R)

${ }^{a}$ Additionally, one fernale weighing $30.0 \mathrm{~g}$ had recently given birth; other females weighing 30,32 , and $36 \mathrm{~g}$ were nulliparous. Two females weighing more than $36 \mathrm{~g}$ were not reproductively active.

\section{Oryzomys fulvescens \\ Pygmy Rice Rat, Ratón}

Pygmy rice rats are found from central Mexico to eastern Panama (Fig. 95). Perhaps as many as four subspecies of Oryzomys fulvescens are found in Costa Rica, although the status of each of these taxa is in need of review. These subspecies include: $O$. $f$. costaricensis, $O$. $f$. creper (the subspecies occurring at La Selva), $O$. $f$. pacificus, and $O . f$. vegetus.

Pygmy rice rats are the smallest Oryzomys found in Costa Rica and among the smallest of all rodents found in the country. They are nocturnal and semiarboreal.

Fig. 95. Pygmy rice rat, Oryzomys fulvescens. Photo by B. L. Clauson.

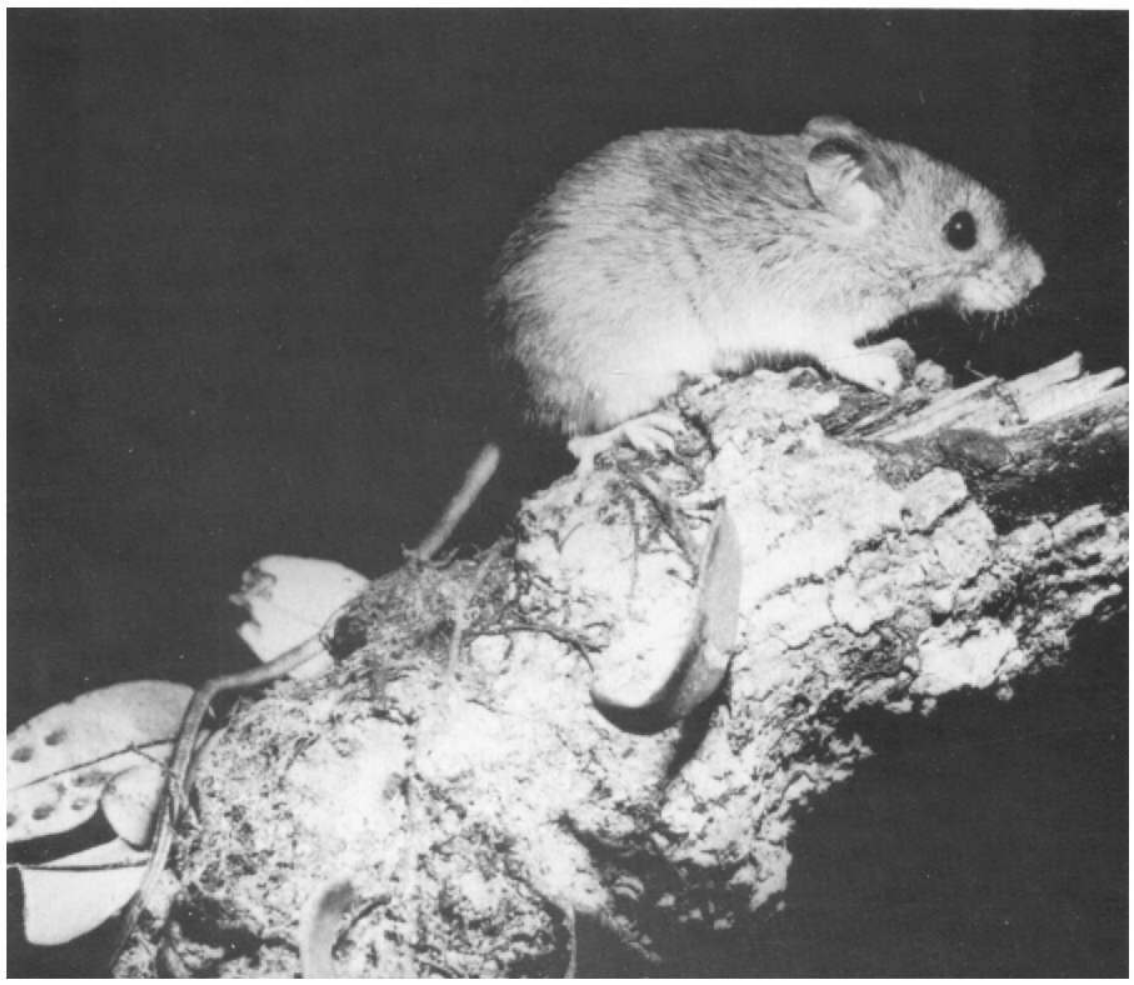


Oryzomys fulvescens occupies a variety of habitats and a wide range of elevations from near sea level to $3,400 \mathrm{~m}$. They are frequently trapped in open grassy and weedy habitats which suggests that they might be more abundant now in disturbed habitats than they were in pristine forests. In Nicaragua, Jones and Engstrom (1986) reported that pregnant females carried an average of four embryos, with a range of three to six.

Only three specimens of $O$. fulvescens are known from Heredia Province. A single adult female was obtained by E. H. Taylor along the Río Puerto Viejo on 6 August 1954 "under a log," and a male and female were trapped south of Cariblanco in August 1967. We suspect that the few records from this region reflect a lack of concerted effort in searching for pygmy rice rats in appropriate habitats, and not that the species is rare.

Specimen examined (1)-Puerto Viejo River [1 female, KU].

Additional records (2) $-1.5 \mathrm{mi} \mathrm{S}$ of Cariblanco [1 male, 1 female, MVZ].

\section{Peromyscus nudipes \\ Cloud Forest Deer Mouse, Ratón}

The systematic status of the white-footed mice and deer mice (genus Peromyscus) in Central America is in a state of flux (Fig. 96). Specimens of Peromyscus collected $5 \mathrm{~km}$ SE of Turrialba, Cartago Province, were regarded by Hall and Kelson (1959) and later by Hall (1981) as representing Peromyscus mexicanus saxatilis, whereas all other specimens from Costa Rica were regarded as representing a high-elevation species, $P$. nudipes, which was restricted to Costa Rica and adjacent Panama. In a revision of the $P$. mexicanus group, Huckaby (1980) reduced the name nudipes to a junior synonym of $P$. mexicanus. Thus, all Peromyscus, within Costa Rica would represent the widespread species $P$. mexicanus, which, as Huckaby defined it, ranges from San Luis Potosí and Veracruz, Mexico, to western Panama. He recognized no subspecies within $P$. mexicanus, although he did state that there was considerable geographic variation. Huckaby's concept of the species $P$. mexicanus has not been supported universally by subsequent authors. The morphology of the $\mathrm{Y}$ chromosome of nudipes differs from $P$. mexicanus in that nudipes has a small metacentric $\mathrm{Y}$, whereas in $P$. mexicanus the $\mathrm{Y}$ is a small acrocentric (Rogers et al. 1984; Smith et al. 1986). In both studies, $P$. nudipes was regarded as a distinct species.

The mean litter size, as judged by counts of embryos and recent placental scars of eight adult females, was 2.5 (Table 3 ). Mean testes length and width for 17 adult males was $15.1 \times 8.5 \mathrm{~mm}$.

Ticks collected from cloud forest deer mice include Ixodes venezuelensis (6 nymphs).

Specimens examined (46)-Barva, Sta. Lucia [ 2 males, 3 females, UNA]; 2 km $\mathrm{N}, 0.5 \mathrm{~km}$ E of Sacramento, 2,600 m [6 males, 3 females, UNA]; $1 \mathrm{~km} \mathrm{~S}, 11.5 \mathrm{~km}$ E of San Miguel, $710 \mathrm{~m}$ [ 3 males, 5 females, FMNH; 2 males, 1 female, UNA]; $3.5 \mathrm{~km} \mathrm{~S}, 11.5 \mathrm{~km}$ E of San Miguel, 750 and 1,000 m [7 males, 8 females, FMNH; 1 male, UNA]; $5 \mathrm{~km}$ E of Vara Blanca, $2,050 \mathrm{~m}$ [ 3 males, 2 females, FMNH]. Additional record (1) $-1.5 \mathrm{mi} \mathrm{W}$ of Cariblanco [1 female, MVZ]. 


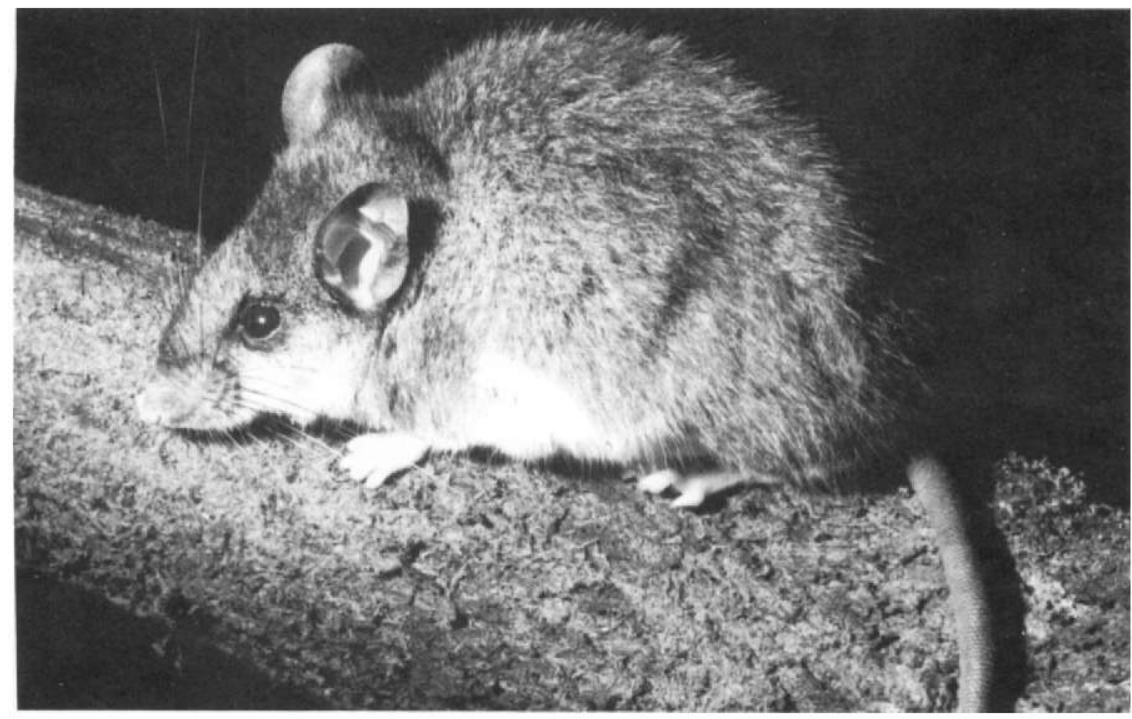

Fig. 96. Cloud forest deer mouse, Peromyscus nudipes. Photo by B. L. Clauson.

Table 3. Reproductive characteristics of 10 adult (weight $>40 \mathrm{~g}$ ) female Peromyscus nudipes from Heredia Province, Costa Rica. ${ }^{a}$

Date of

capture

Reproductive characteristics

4 April 1986

3 placental scars $(2 \mathrm{~L}-1 \mathrm{R})$

4 April 1986

2 embryos $\times 5 \mathrm{~mm}(1 \mathrm{~L}-1 \mathrm{R})$ plus old placental scars

5 April 1986

2 embryos $\times 12 \mathrm{~mm}(2 \mathrm{R})$ plus old placental scars

5 April 1986

2 embryos $\times 6 \mathrm{~mm}(1 \mathrm{~L}-1 \mathrm{R})$

7 April 1986

2 recent placental scars (1L-1R) plus old placental scars, lactating

8 April 1986

3 embryos $\times 8 \mathrm{~mm}(1 \mathrm{~L}-2 \mathrm{R})$

8 April 1986

3 embryos $\times 8 \mathrm{~mm}(2 \mathrm{~L}-1 \mathrm{R})$

8 April 1986

pregnant female; released

10 April 1986

3 recent placental scars (L), lactating

18 April 1986

uterus enlarged, lactating

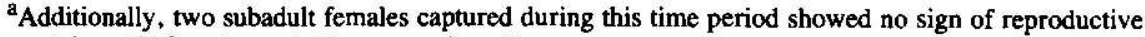
activity. All females weighing more than $40 \mathrm{~g}$ were reproductively active. 


\section{Reithrodontomys creper \\ Chiriquí Harvest Mouse, Ratón de la Cosecha}

Chiriquí harvest mice have been reported from the Cordillera Central of Costa Rica, as far north as volcanos Irazú, Barva, and Poás, and southward through the Talamancas to the Chiriquí highlands of western Panama (Fig. 97). Recently, we have found Reithrodontomys creper to be abundant in the cloud forests above Monteverde, Puntarenas Province, thus extending the known range of the species farther north and west in Costa Rica into the Cordillera de Tilaran. Also, we have caught $R$. creper at San Gerardo de Dota, San José Province, at 2,600 m in pastures and in 5-year-old scrub that had been pasture. These are high-elevation mice; localities of capture range from $1,300 \mathrm{~m}$ near Angel Falls to more than $3,000 \mathrm{~m}$. Although Chiriquí harvest mice are not uncommon in the appropriate habitat, at these higher elevations, rodents have not been studied intensively and little has been published on their biology. This species seems to prefer pristine forest as there have been few reports of it in second growth or disturbed habitats. There are no subspecies of $R$. creper recognized.

We encountered $R$. creper at $2,050 \mathrm{~m}$ in the park, and we suspect that it occurs throughout much of the higher-elevation forests of Braulio Carrillo. Oryzomys albigularis, Peromyscus nudipes, and Scotinomys teguina were the abundant small mammals encountered along with $R$. creper at this site. Two adult females collected on 17 and 20 April each carried three embryos, both had one embryo in the left uterine horn and two in the right. Embryos from one female had crownrump lengths of $4 \mathrm{~mm}$, those from the second had crown-rump lengths of $5 \mathrm{~mm}$. A third adult female was not pregnant. Three adult males had testes that measured $19 \times 10 \mathrm{~mm}, 19 \times 9 \mathrm{~mm}$, and $15 \times 9 \mathrm{~mm}$.

Specimens examined (5) $-5 \mathrm{~km}$ E of Vara Blanca, 2,050 m [3 males, 2 females, FMNH].

Additional records (4)-Altos de Roble, S Fork Río Las Vueltas, 1,450 m [3, LACM]; $1.2 \mathrm{mi} \mathrm{N}$ of Angel Falls, 1,300 m [1, LACM].

\section{Reithrodontomys rodriguezi \\ Rodriguez's Harvest Mouse, Ratón de la Cosecha}

Reithrodontomys rodriguezi was described originally on the basis of two subadult specimens from Volcán Irazú, Cartago Province, at 9,400 ft $(2,865 \mathrm{~m})$ by Goodwin (1943). He described it as "A moderately large harvest mouse with soft dense pelage, long unicolor tail, large ears and white underparts," and stated that the holotype was taken in long grass at the edge of rain forest (Goodwin 1943:1). For the next four decades the species was not encountered again and remained perhaps the most poorly known and enigmatic mammal of the country. Single specimens are now known from Asunción and Volcán Irazú, both in Cartago Province (McPherson 1985). The presence of $R$. rodriguezi on Volcán Barva was noted recently by Lumer and Schoer (1986), who felt that this was one of several species of rodents that pollinated flowers of Blakea sp.

We encountered $R$. rodriguezi at two localities on the northeastern slope of Volcán Barva during the 1986 expeditions. Specimens were taken at elevations 


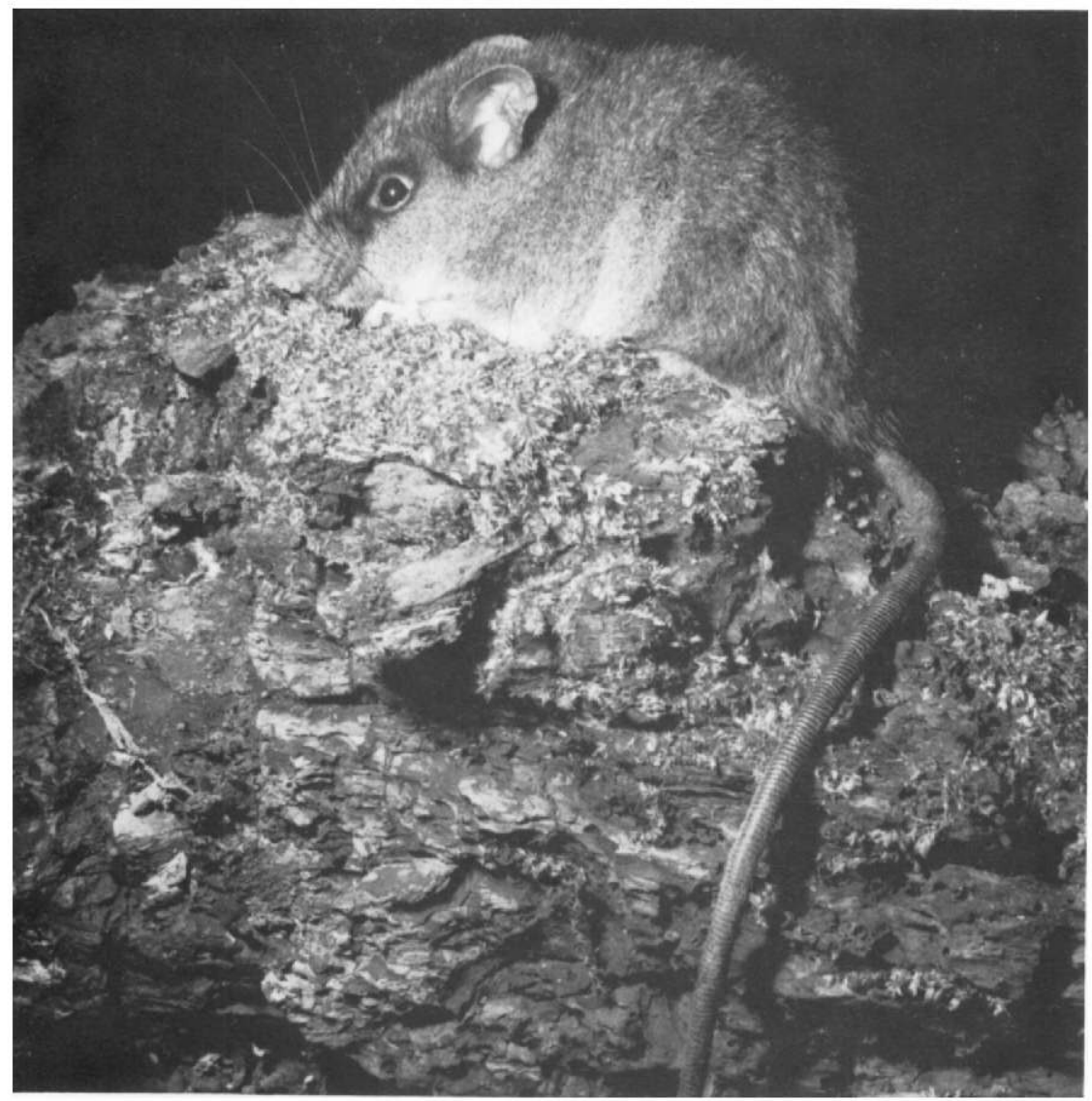

Fig. 97. Chiriquí harvest mouse, Reithrodontomys creper. Photo by B. L. Clauson.

ranging from 1,500 to $2,500 \mathrm{~m}$.

Specimens examined (3)-Parque Nacional Braulio Carrillo, 2,500 m [1 female, UNA]; 9 km S, $11.5 \mathrm{~km}$ E of San Miguel, 1,500 m [2 females, KU].

Additional record (1)-Cerro Chompipe, Volcán Barva, 2,090 m [AMNH].

\section{Mus musculus}

\section{House Mouse, Ratón de Casa}

The house mouse was indigenous to the Old World, perhaps being found originally through much of central Asia from the Mediterranean to China. It is now a commensal that has followed humans throughout much of the world.

We captured only two house mice at $2,600 \mathrm{~m}$ during the survey. The adult female weighed $14.7 \mathrm{~g}$, the adult male weighed $14.3 \mathrm{~g}$ and had testes measurements of $7 \times 4 \mathrm{~mm}$.

Specimens examined (2) $-2 \mathrm{~km} \mathrm{~N}, 0.5 \mathrm{~km}$ E of Sacramento, 2,600 m [1 male, 1 female, UNA]. 


\section{Scotinomys teguina \\ Alston's Brown Mouse, Ratón}

Alston's brown mouse is found at higher elevations from southern Mexico to the Chiriquí mountains of western Panama (Fig. 98). Two subspecies of Alston's brown mouse occur in Costa Rica, Scotinomys teguina irazu throughout most of the mountainous regions of the country and $S$. $t$. apricus in extreme southern Costa Rica.

Scotinomys is an abundant rodent in a wide variety of habitats. It is apparently highly insectivorous and uses audible high-pitched vocalizations for intraspecific communication. Brown mice are active during daylight as well as at night.

We captured four adult females in mid-April. One carried two embryos in the left uterine horn with crown-rump lengths of $11 \mathrm{~mm}$; one had four recent placental scars, three in the left uterine horn and one in the right; one was lactating; and one had no embryos. A juvenile male was captured on 13 April. Scotinomys was frequently captured during the day, attesting to the diurnal activity of these insectivorous rodents.

Specimens examined (17)-2 km N, $0.5 \mathrm{~km}$ E of Sacramento, 2,600 m [ 2 males, 2 females, UNA]; San José de la Montaña, Paso Llano, 1,800 m [1 male, 2 females, 3 unknown, KU]; $9 \mathrm{~km} \mathrm{~S}, 11.5 \mathrm{~km} \mathrm{E}$ of San Miguel, 1,500 and 1,520 m [1 male, 3 females, FMNH; 1 female, UNA]; $5 \mathrm{~km} \mathrm{E}$ of Vara Blanca, $2,050 \mathrm{~m}$ [1 male, 1 female, UNA].

Additional records (2)-1.2 mi $\mathrm{N}$ of Angel Falls [2, LACM].

Fig. 98. Alston's brown mouse, Scotinomys teguina. Photo by B. L. Clauson.

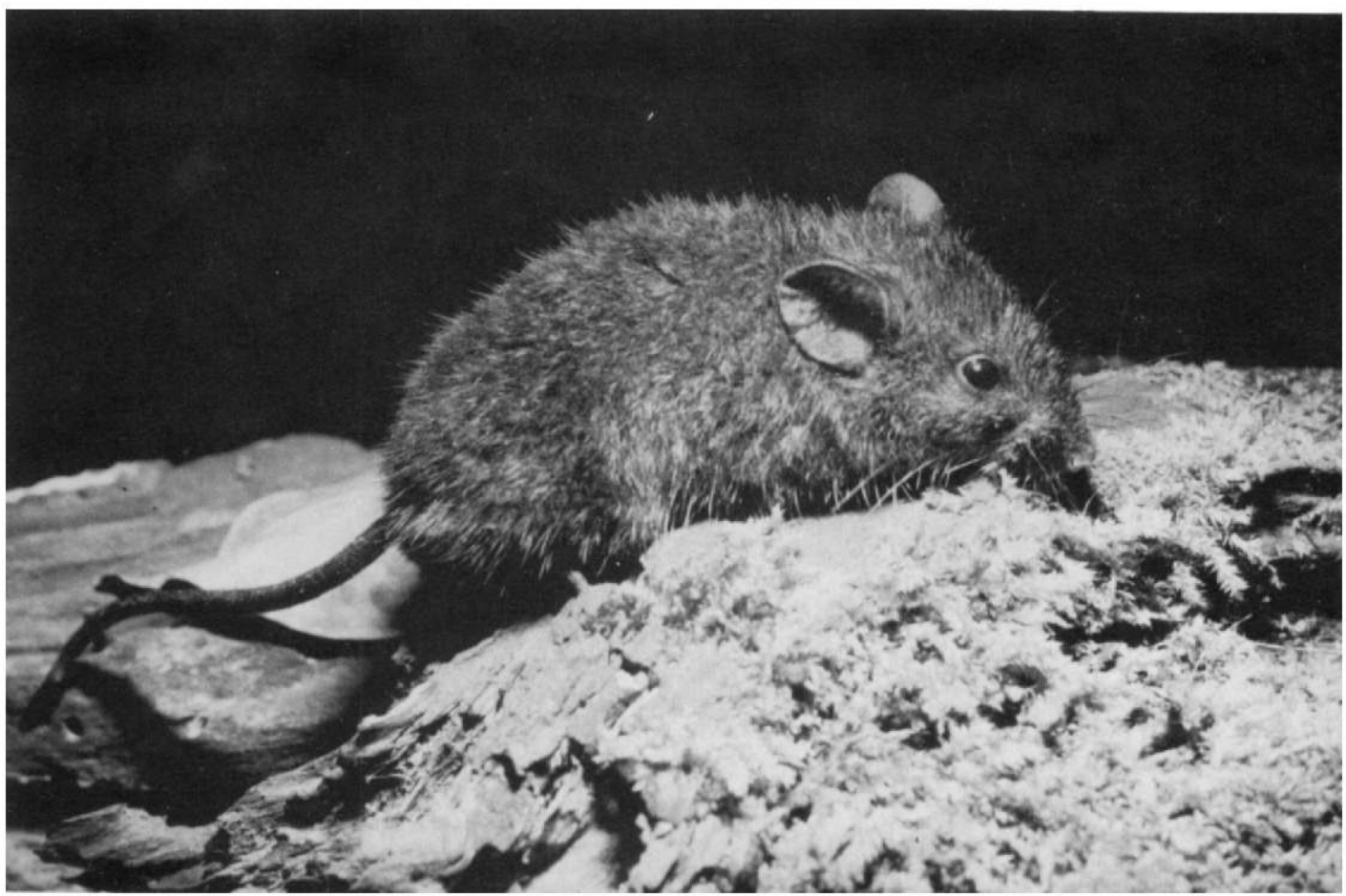




\section{Tylomys watsoni \\ Watson's Climbing Rat, Rata Azul}

Watson's climbing rat is found throughout much of Costa Rica and Panama, but has not been taken in adjacent countries (Fig. 99). No subspecies of Tylomys watsoni are recognized, and little is known of its ecology and habitat requirements. It is found from sea level to high elevation cloud forest.

Apparently, $T$. watsoni has been seen only once at La Selva. Fleming (1973) reported that one Watson's climbing rat was captured there by W. H. Freeland.

Fig. 99. Watson's climbing rat, Tylomys watsoni. Photo by B. L. Clauson.

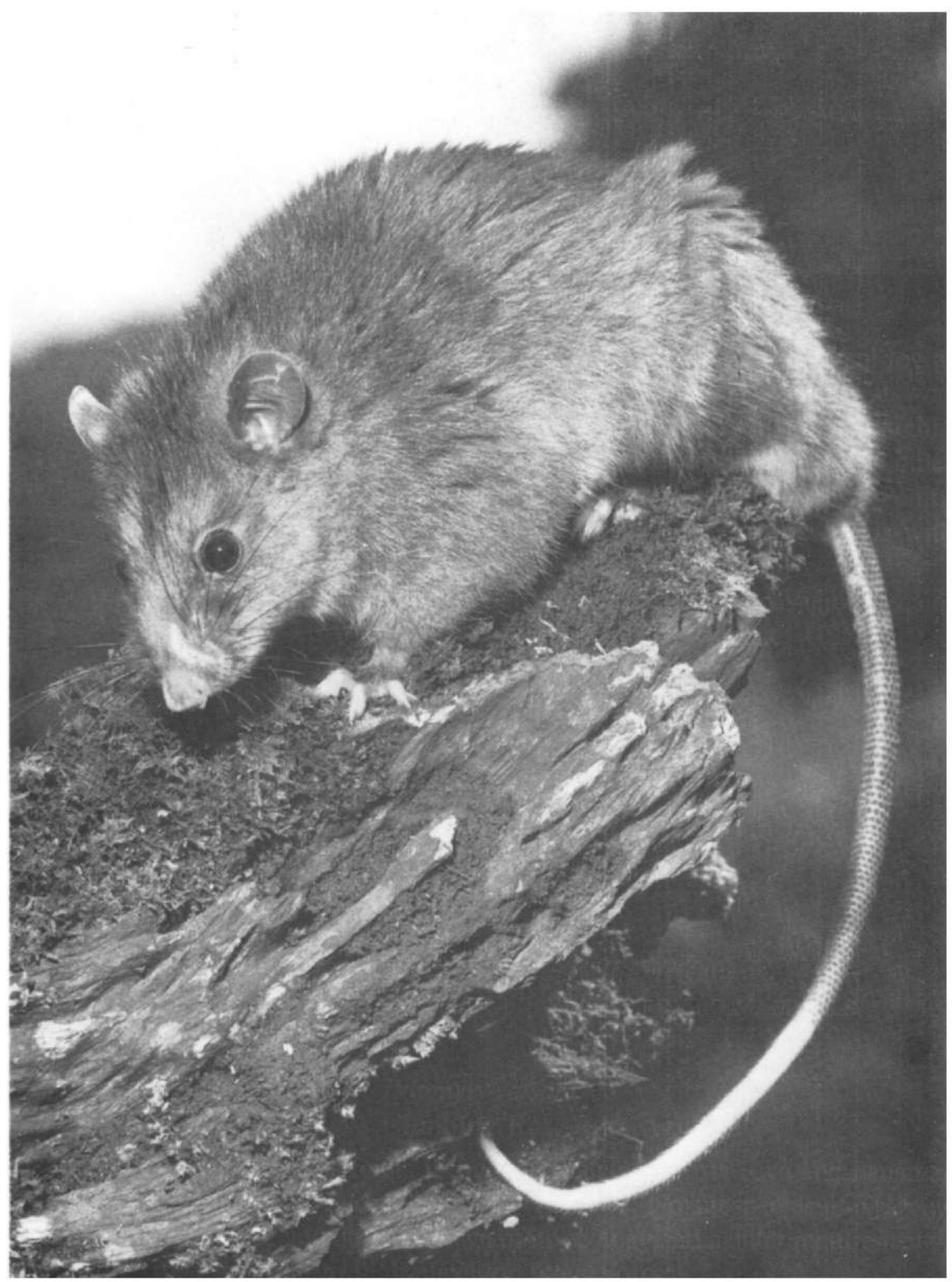




\section{Family Erethizontidae}

\section{Coendou mexicanus \\ Prehensile-tailed Porcupine, Puercoespín}

Prehensile-tailed porcupines are found from east-central Mexico to extreme western Panama (Fig. 100). The subspecies Coendou mexicanus laenatus is found throughout most of Costa Rica from sea level to about 3,000 m.

A prehensile-tailed porcupine was found dead along a road near the $2,050-\mathrm{m}$ base camp; only bones and the distinctive hair remained. If the animal had been killed by hunters and the remains discarded there, it probably was taken in the general vicinity. Within Parque Nacional Braulio Carrillo, C. mexicanus was observed near the guard station at $2,600 \mathrm{~m}$ and near Laguna Barva at $2,700 \mathrm{~m}$. Prehensile-tailed porcupines have been observed at La Selva on only five occasions: 1965, 9 March 1980, late July 1981, 23 November 1986, and May 1987. The biology of this species in Costa Rica was reviewed recently by Janzen (1983a).

Specimen examined (1)-Finca La Selva, $3 \mathrm{~km} \mathrm{~S}$ of Puerto Viejo [1 female, MNCR].

Fig. 100. Prehensile-tailed porcupine, Coendou mexicanus. Photo by B. L. Clauson.

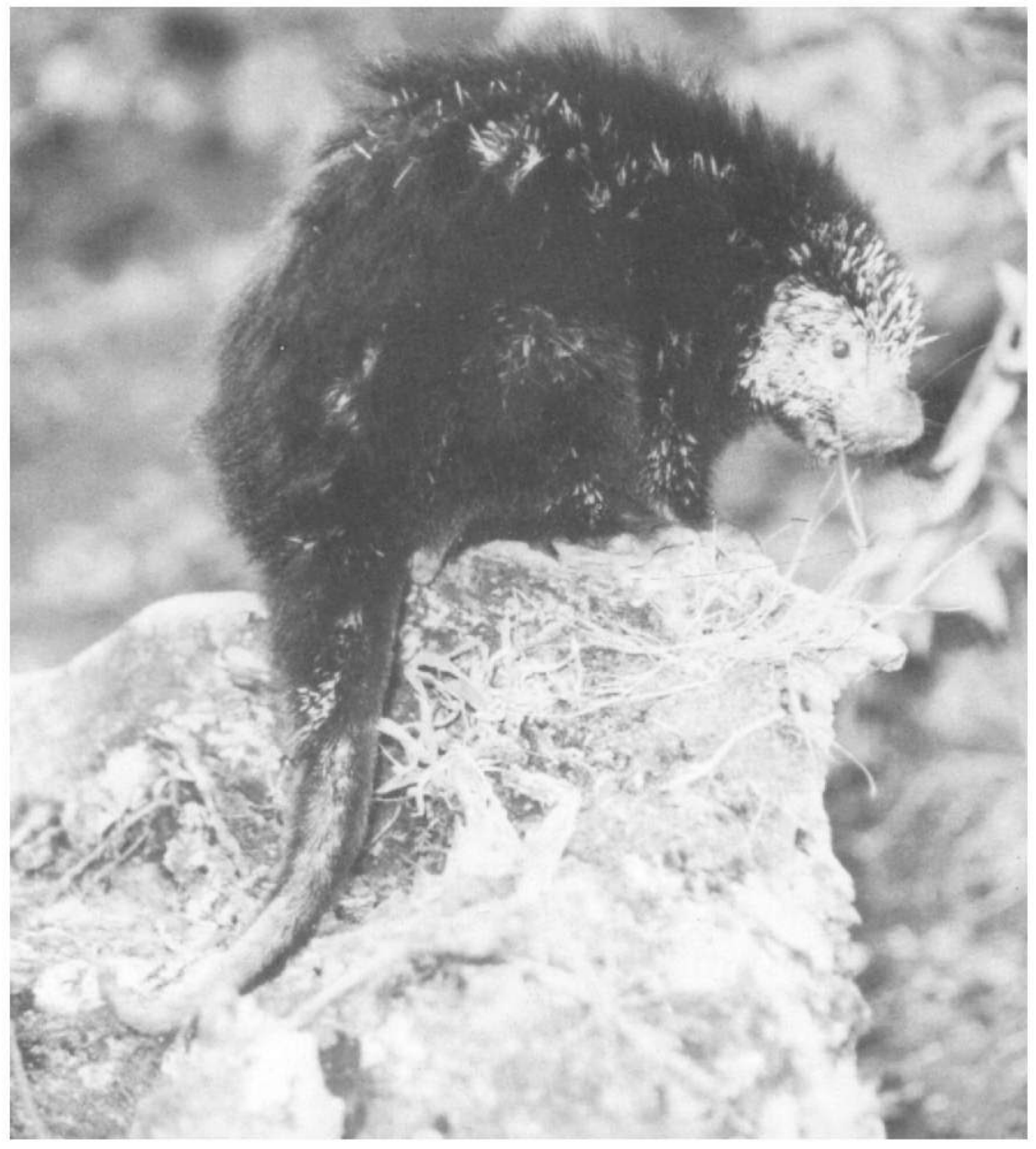




\section{Family Agoutidae \\ Agouti paca \\ Paca, Tepezcuintle}

Pacas, the largest rodents in Costa Rica, are found from east-central Mexico south through all of Costa Rica and the northern two-thirds of South America to Paraguay, Uruguay, and southeastern Brazil (Fig. 101). Two subspecies are recognized in Costa Rica: Agouti paca nelsoni in the northwest Guanacaste region and $A$. $p$. virgatus throughout the rest of the country including La Selva. Due to their nocturnal, secretive nature, and because they are a highly prized and heavily hunted game species (Smythe 1983), they are rarely seen.

Pacas are common, but no longer abundant members of the La Selva fauna. They have been observed there year round. In June 1983, an adult and single juvenile were observed, and a lone juvenile was seen on 8 July 1988 . In the past few years, sightings of pacas have increased at La Selva suggesting that the population is increasing. Pacas feed on the seeds of Carapa guianensis (Meliaceae), a common tree in swampy areas at La Selva, and they are one of the major vertebrate predators of these seeds (McHargue and Hartshorn 1983).

Pringle et al. (1984:198) reported "We repeatedly saw tracks of Agouti paca (paca), and once found a hunters' blind with paca hair beneath it on a ridge above the Río Sardinalito"' in the Zona Protectora.

\section{Family Dasyproctidae}

\section{Dasyprocta punctata Agouti, Guatusa}

Agoutis occur from southern Mexico to extreme northern Argentina (Fig. 102). Four subspecies of Dasyprocta punctata currently are recognized in Costa Rica (Hall 1981), with a single subspecies, D. p. richmondi, found throughout the Caribbean luwlands, mid- and high-elevation slopes. Agoutis are found in Costa Rica from sea level to high elevations; they occur at least as high as $2,400 \mathrm{~m}$.

Agoutis are territorial and primarily monogamous; however, when abundant resources are available, a male may have two or more mates. Annually each mated female produces a single highly precocious young (Smythe 1983).

Agoutis are one of the most frequently observed mammals at La Selva. They are abundant in the primary forest and may be seen from the trails nearly every day. An adult and two young were seen in May 1981 and August 1983. Two were seen copulating in November 1982. In September 1982, an agouti was seen running from a small felid, probably a margay (Felis wiedii). Agoutis have been observed eating the fruits of Dipteryx panamensis and pejibaye palms, Bactris gasipaes, at La Selva. Vandermeer et al. (1979:19) reported that agoutis were observed eating the fruits of the palm Welfia georgii; the behavioral repertoire included "picking up fruits from the ground, shucking them, eating the mesocarp and either eating the seed, dropping it to the ground, or burying it." Seeds of two other species of trees are heavily utilized by agoutis, Carapa guianensis and Matisia ochrocalyx (Bombacaceae). For all these tree species, agoutis may serve both as 


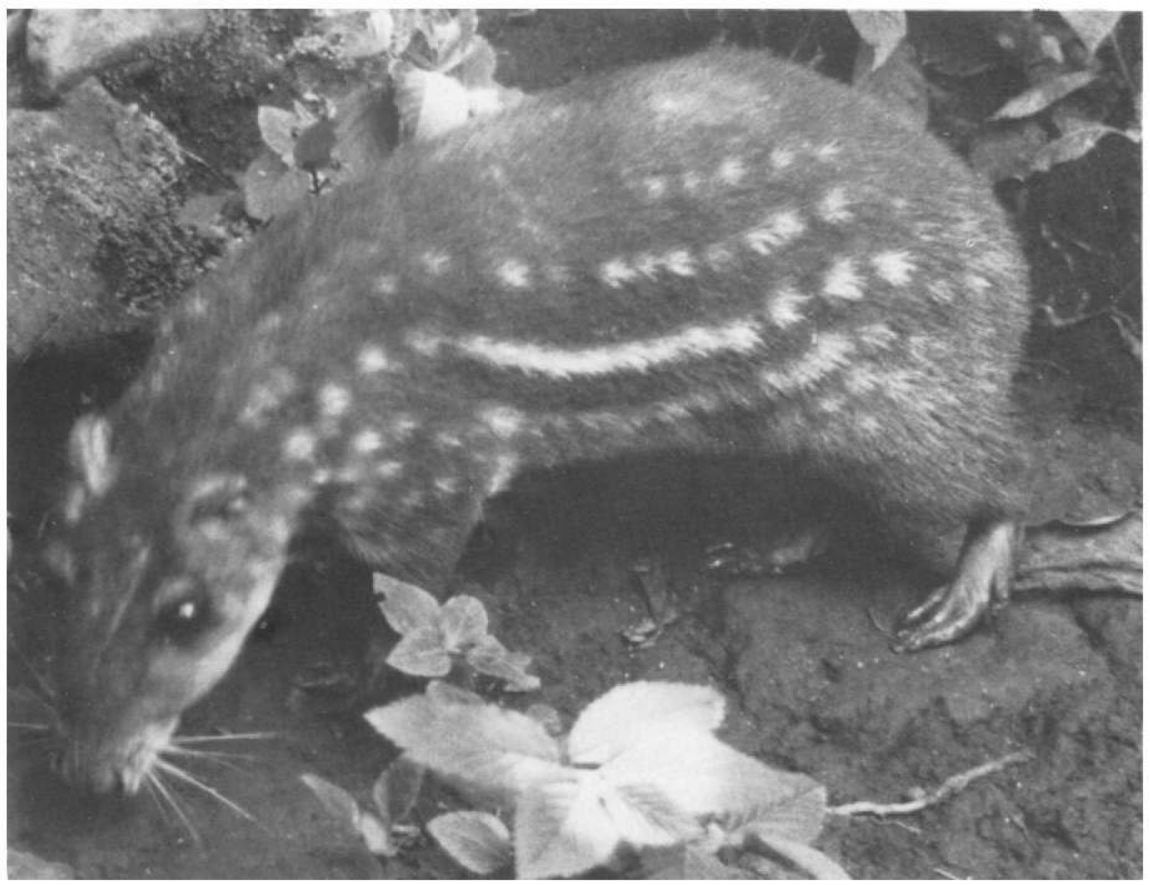

Fig. 101. Paca, Agouti paca. Photo by R. M. Timm.

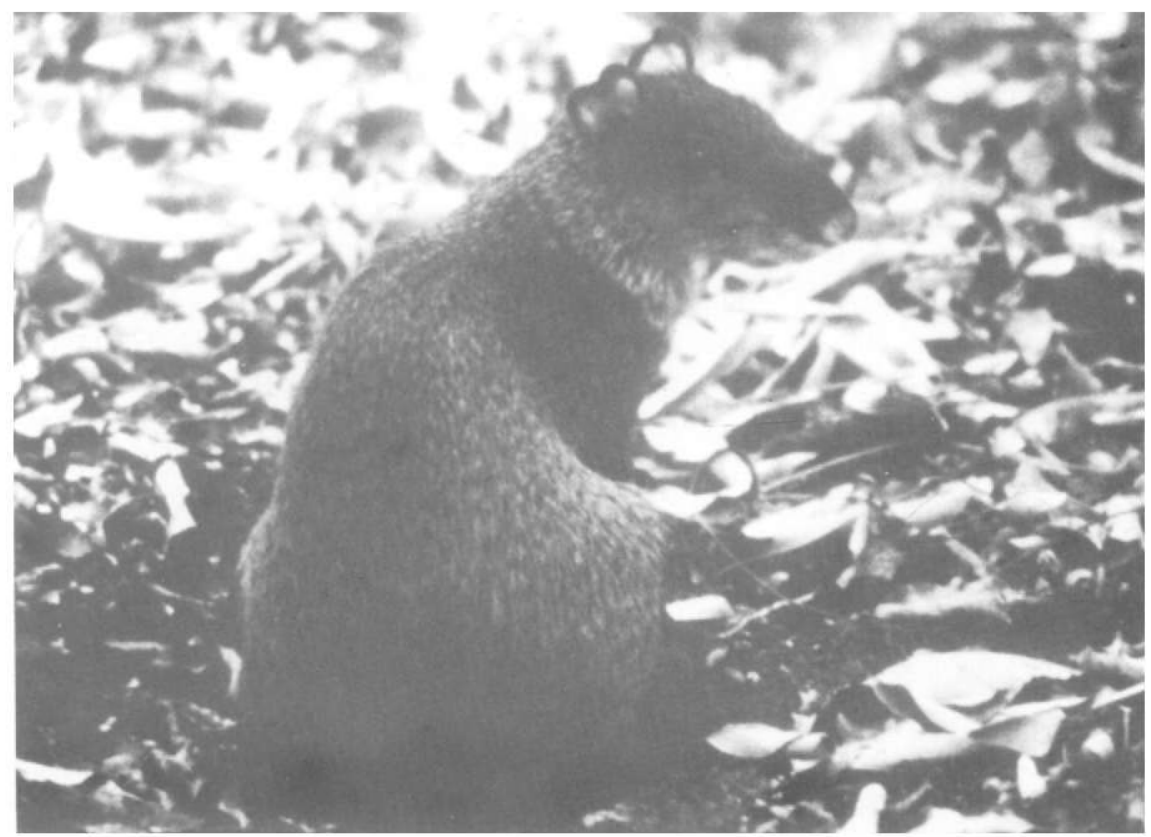

Fig. 102. Agouti, Dasyprocta punctata. Photo by J. K. Adams. 
major vertebrate predators on the seeds and as principal dispersal agents, although Larson and Howe (1987) noted the lack of data on the actual effect of agoutis on specific species. One of the best places to observe agoutis at La Selva is the pejibaye grove.

Single agoutis were seen by members of our group at $100 \mathrm{~m}$ and $300 \mathrm{~m}$ within Parque Nacional Braulio Carrillo. The natural history of the agouti in Central America, based primarily on studies at Barro Colorado Island, Panama, was detailed by Smythe (1978).

\section{Family Echimyidae}

\section{Hoplomys gymnurus Armored Rat, Ratón}

Armored or thick-spined rats are distributed from the Caribbean lowlands of extreme southeastern Honduras south through the tropical lowlands of Nicaragua, Costa Rica, and Panama to western Colombia and Ecuador. Two subspecies are known from Costa Rica, Hoplomys gymnurus goethalsi from southern Costa Rica and adjacent Panama and $H$. g. truei from central, eastern, and northern Costa Rica.

We obtained a single adult that was crossing a log over the Río Cantarrana at $280 \mathrm{~m}$. Armored rats are certainly present at La Selva, although we know little of their abundance because they are rarely observed. Vandermeer et al. (1979) reported that they were able to capture Hoplomys in live traps using the fruit of the palm Welfia georgii as bait. They also noted that $H$. gymnurus readily consumed the mesocarp of $W$. georgii and would also eat the seeds if other foods were not available. It is likely that $H$. gymnurus and the closely related and similarly sized spiny rat, Proechimys semispinosus, are major food items of bushmasters.

Specimens examined (3)-Finca La Selva, $3 \mathrm{~km} \mathrm{~S}$ of Puerto Viejo [2 females, UMMZ]; $11 \mathrm{~km} \mathrm{S,} 4.5 \mathrm{~km}$ W of Puerto Viejo, $280 \mathrm{~m}$ [1 female, FMNH].

\section{Proechimys semispinosus Tomes' Spiny Rat, Ratón}

Tomes' spiny rat is widely distributed at lower elevations from southeastern Honduras and eastern Nicaragua through Costa Rica except in the northwest and along the western Andean lowlands of South America to southwestern Ecuador. Although the group is in need of revision, three subspecies of spiny rats are recognized from Costa Rica (Gardner 1983c): Proechimys semispinosus rubellus is known only from Pacuare, the type locality; $P$. $s$. centralis is found in northern Costa Rica with the exception of Guanacaste; and $P$. $s$. panamensis is found throughout the rest of the country. This species is captured occasionally at La Selva, although we know little of its biology in Central America. Greene (1988) reported that bushmasters prey primarily on spiny rats at La Selva.

Specimens examined (4)-Puerto Viejo, $100 \mathrm{~m}$ [1 male, KU]; Finca La Selva, $3 \mathrm{~km} \mathrm{~S}$ of Puerto Viejo [2 males, UMMZ]; $5.7 \mathrm{mi}$ S of Puerto Viejo [1 female, LACM].

Additional record (1)-7.3 mi SE of Puerto Viejo [1 male, TTU]. 


\title{
ORDER CARNIVORA
}

\author{
Family Canidae \\ Canis latrans \\ Coyote
}

Coyotes are found from extreme northern Alaska and northwestern Canada across most of the United States, Mexico, and Central America to western Panama. A single subspecies of coyote, Canis latrans dickeyi, is found in Costa Rica. There is considerable controversy concerning the original distribution of coyotes in the country. It is documented in some of the earliest faunal reports that coyotes were abundant in Guanacaste Province and adjacent Nicaragua at the time of colonization by the Spanish and that the species is expanding its range in Central America (Monge-N. and Morera 1986, 1987). Vaughan (1983b) suggested that coyotes in Costa Rica originally were restricted to the tropical dry forests, and have rapidly expanded their range in Costa Rica and into Panama with the progress of recent deforestation. Coyotes in Costa Rica are opportunistic: in lowland dry Costa Rica they feed mostly on mammals, reptiles, and to a lesser degree on vegetation, birds, and arthropods (Janzen 1983b), whereas in the highlands the diet is almost exclusively mammals and birds (Vaughan and Rodriguez 1986).

During our 1986 expedition to Parque Nacional Braulio Carrillo, we found coyote scats in a pasture at $2,000 \mathrm{~m}$, heard coyotes howling at $2,050 \mathrm{~m}$, and observed their tracks at $2,600 \mathrm{~m}$. There were no previous records of coyotes in the park.

\section{Family Procyonidae \\ Bassaricyon gabbii Olingo, Martilla}

Olingos are found from central Nicaragua to western Colombia and Ecuador. Two subspecies are found in Costa Rica, the nominate race, Bassaricyon gabbii gabbii, in the south and $B . g$. richardsoni in the north. A second species, B. lasius is known from only the type locality at Estrella de Cartago in Cartago Province.

Olingos have been observed on a dozen occasions at La Selva. In August 1982 and again in July of 1988, single individuals were seen feeding on the fruits of Cecropia. Two individuals were observed together on 8 April 1988. Olingos are frequently misidentified as kinkajous.

Specimens examined (2)-Puerto Viejo, Río Sarapiquí, $300 \mathrm{ft}$ [1 male, 1 female, UMMZ]. 


\section{Nasua narica Brown-nosed Coati, Pizote}

Northern or brown-nosed coatis range from the southwestern United States through much of Central America to northwestern Colombia (Fig. 103). Coatis are extremely adaptable and are found in a wide variety of habitats including deserts, tropical dry forests, and tropical wet forests. The subspecies Nasua narica narica is found in Costa Rica from sea level to at least $3,500 \mathrm{~m}$. Originally, coatis probably occurred in all natural terrestrial habitats in Costa Rica. The correct scientific name for the Central and South American coatis has varied over the years as several species and subspecies of Nasua have been described (Honacki et al. 1982). We concur with Decker (in litt.) in recognizing only two species of coatis; Nasua narica, the northern or brown-nosed coati in Central America, and N. nasua, the whitenosed coati, a widely distributed species in South America. The Cozumel Island coati is probably best considered as an endemic insular subspecies, N. n. nelsoni, of the Central American species.

Coatis are the most social of the procyonids. Adult males are solitary, but females and their offspring live in highly organized social groups. Coatis, unlike other procyonids, are active primarily during the day. They are omnivorous, consuming a wide variety of fruits, insects, and any smaller vertebrates that they are able to capture, including snakes, frogs, birds, bird eggs, and rodents. An excellent long-term study of the ecology and social behavior of coatis on Barro Colorado Island, Panama, was provided by Kaufmann (1962). The biology of coatis in Central America was reviewed recently by Kaufmann (1983).

In April 1986, we sighted lone coatis at 200 and $300 \mathrm{~m}$ in Parque Nacional Braulio Carrillo. Three coatis were seen together at $500 \mathrm{~m}$, and the characteristic tracks of coatis were observed at 700 and $2,100 \mathrm{~m}$. Coatis have been observed on numerous occasions at La Selva; there are records of sightings year round. The solitary adult males are seen most frequently. As many as 56 individuals have been seen in a group. Juveniles were observed in January, March, July, August, and September. They have been observed eating the fruits of Dipteryx panamensis and Trophis racemosa. In April 1986, we observed a group of 36 coatis eating the fruits of Dipteryx. Pringle et al. (1984) observed coatis in the Zona in January 1983.

\section{Potos flavus \\ Kinkajou, Martilla or Mico de Noche}

Kinkajous are found from tropical and subtropical southern Mexico through Central America to the Mato Grosso of Brazil (Fig. 104). The subspecies Potos flavus chiriquensis occurs throughout Central America to the Darién of Panama. A second Costa Rican subspecies, $P$. $f$. arborensis, was described by Goodwin (1938) for eastern Costa Rica; however, Kortlucke (1973) demonstrated that this subspecies was based on age-dependent characters and thus is not taxonomically valid.

There are numerous reports of kinkajous by researchers at La Selva. They have been found there year around. In April 1981, several kinkajous were observed 


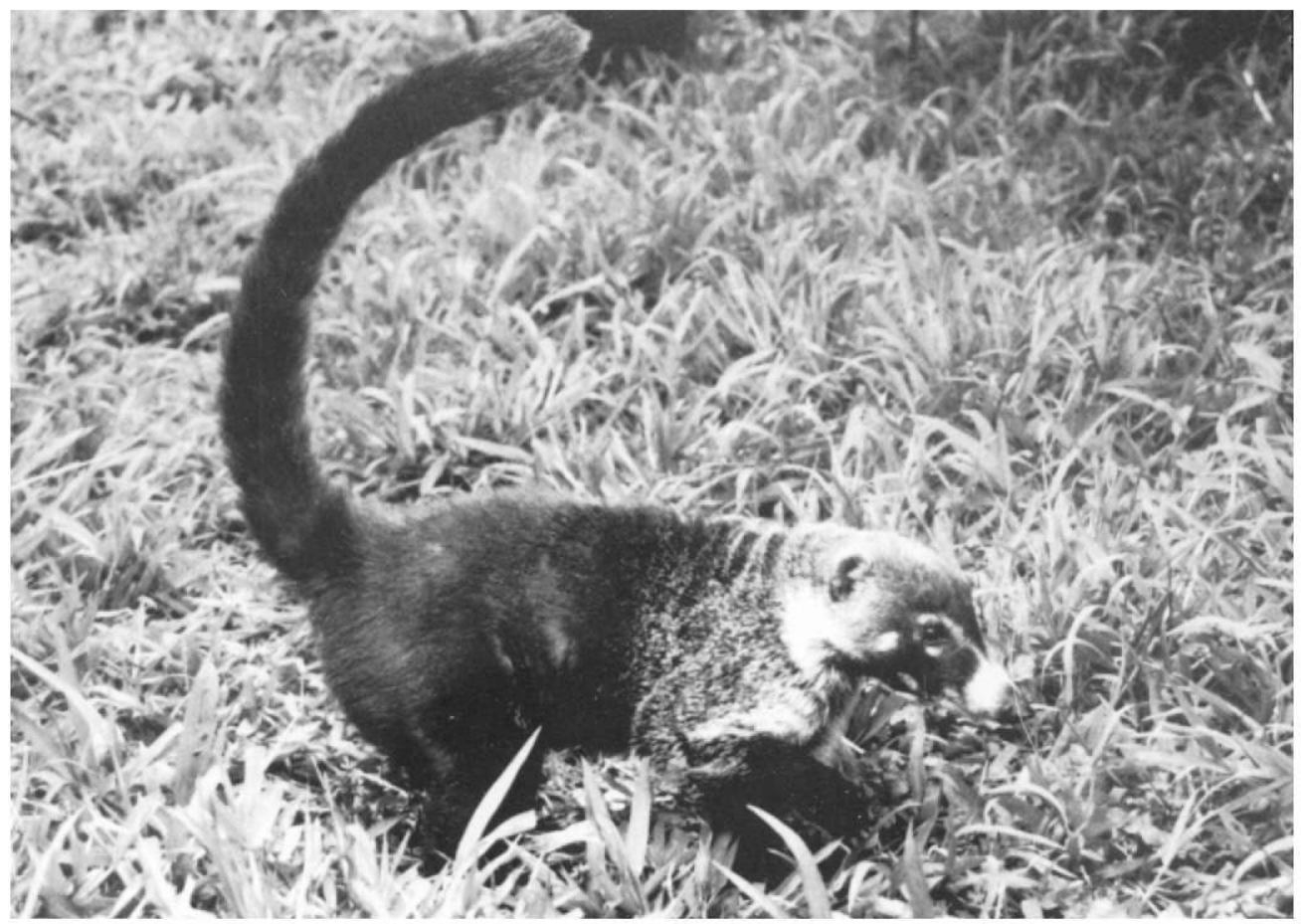

Fig. 103. Brown-nosed coati, Nasua narica. Photo by R. M. Timm.

Fig. 104. Kinkajou, Potos flavus. Photo by $R$. K. LaVal.

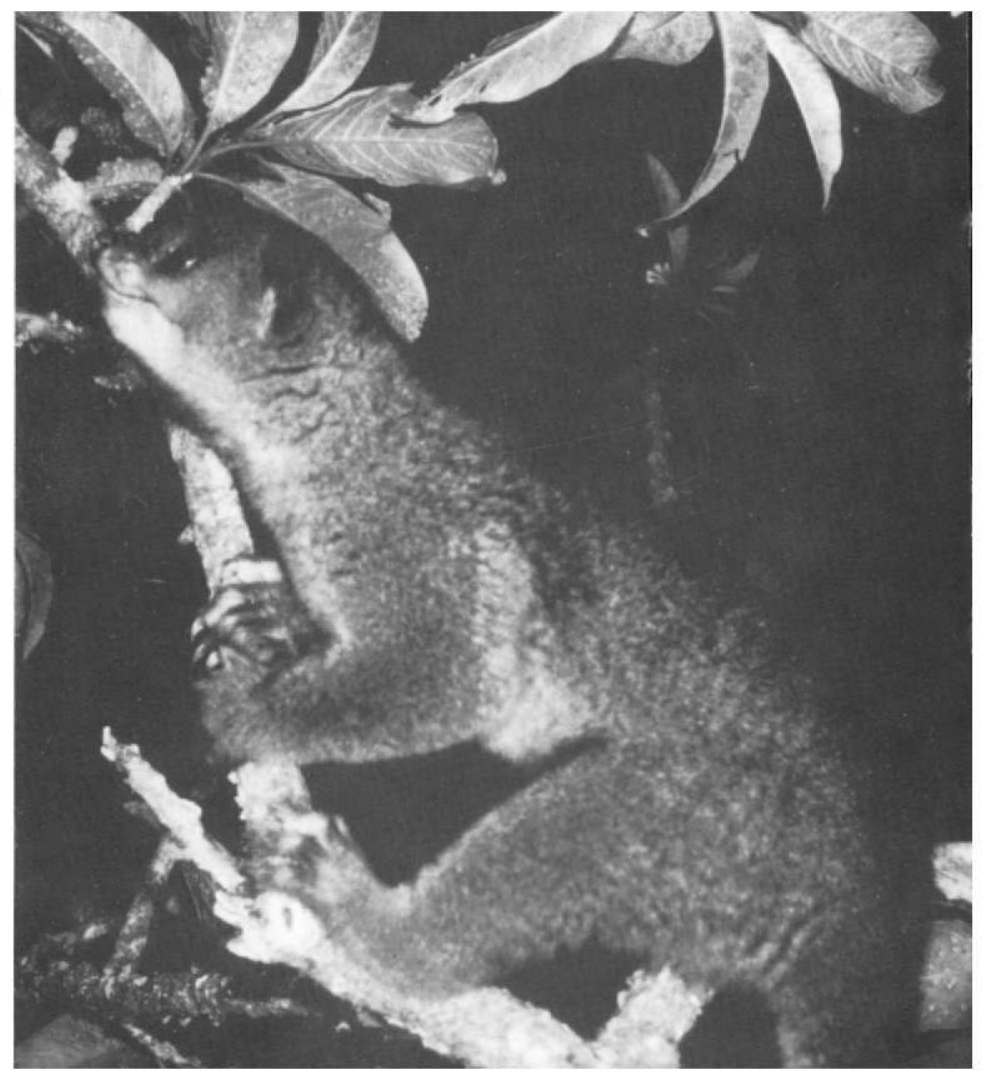


feeding on the fruits of Inga coruscans. Three kinkajous were seen together on 9 July 1988. Kinkajous at La Selva were reported to shuck the fruits of the palm, Welfia georgii, eat the mesocarp, and drop the seeds to the ground (Vandermeer et al. 1979). Pringle et al. (1984) saw one kinkajou in the Zona Protectora in 1983. The biology of kinkajous was reviewed recently by Ford and Hoffmann (1988). Additional records (1)-Puerto Viejo, Río Sarapiquí, $300 \mathrm{ft}$ [1 female, MVZ].

\section{Procyon lotor \\ Raccoon, Mapachín}

Raccoons are found through North America and Central America from southern Canada to eastern Panama, with the exception of the most arid deserts and high elevations of the Rocky Mountains (Fig. 105). Two subspecies of Procyon lotor are found in Costa Rica, $P$. $l$. crassidens throughout most of the country and $P$. $l$. pumilus near the Panamanian border. A second species of raccoon, the crab-eating raccoon (Procyon cancrivorus), also occurs in the country; its known distribution is southwestern Costa Rica, extending as far north as Quepos on the Pacific coast.

Raccoons have been observed on only eight occasions at La Selva; six of these were lone individuals, but two animals were seen together twice. The most recent observation was in August 1987 of a single individual. This paucity of observations of animals as large and easily seen and identified as raccoons suggests that they are uncommon. The biology of raccoons was reviewed by Lotze and Anderson (1979) and in Costa Rica by Sanderson (1983).

\section{Family Mustelidae}

\section{Conepatus semistriatus \\ Striped Hog-nosed Skunk, Zorro Hediondo}

Striped hog-nosed skunks are found from Veracruz, Mexico, eastward along the Caribbean coast of Central America to western Panama. The Costa Rican subspecies, Conepatus semistriatus trichurus, is probably found throughout the country but is observed infrequently. Where hog-nosed skunks are common, such as the Monteverde area, they are frequently killed along roadways by passing vehicles.

Hog-nosed skunks are insectivorous-omnivorous terrestrial foragers. They are one of the most strictly noctural of the Neotropical carnivores. As most observations of these skunks have been of single individuals, we assume that they are solitary.

A striped hog-nosed skunk was observed foraging at the 700 -m base camp along the Río Cascante on two consecutive evenings and one was seen near the 2,600-m base camp in late April. There are 23 observations of striped hog-nosed skunks at La Selva from 1979 through mid-1988. Judging from the close proximity in time and area, these sightings probably represent repeated sightings of few individuals. In recent years, one individual has been seen almost every evening at dusk near the visitor center, in the adjacent second growth, and occasionally on the Río Puerto Viejo bridge. 


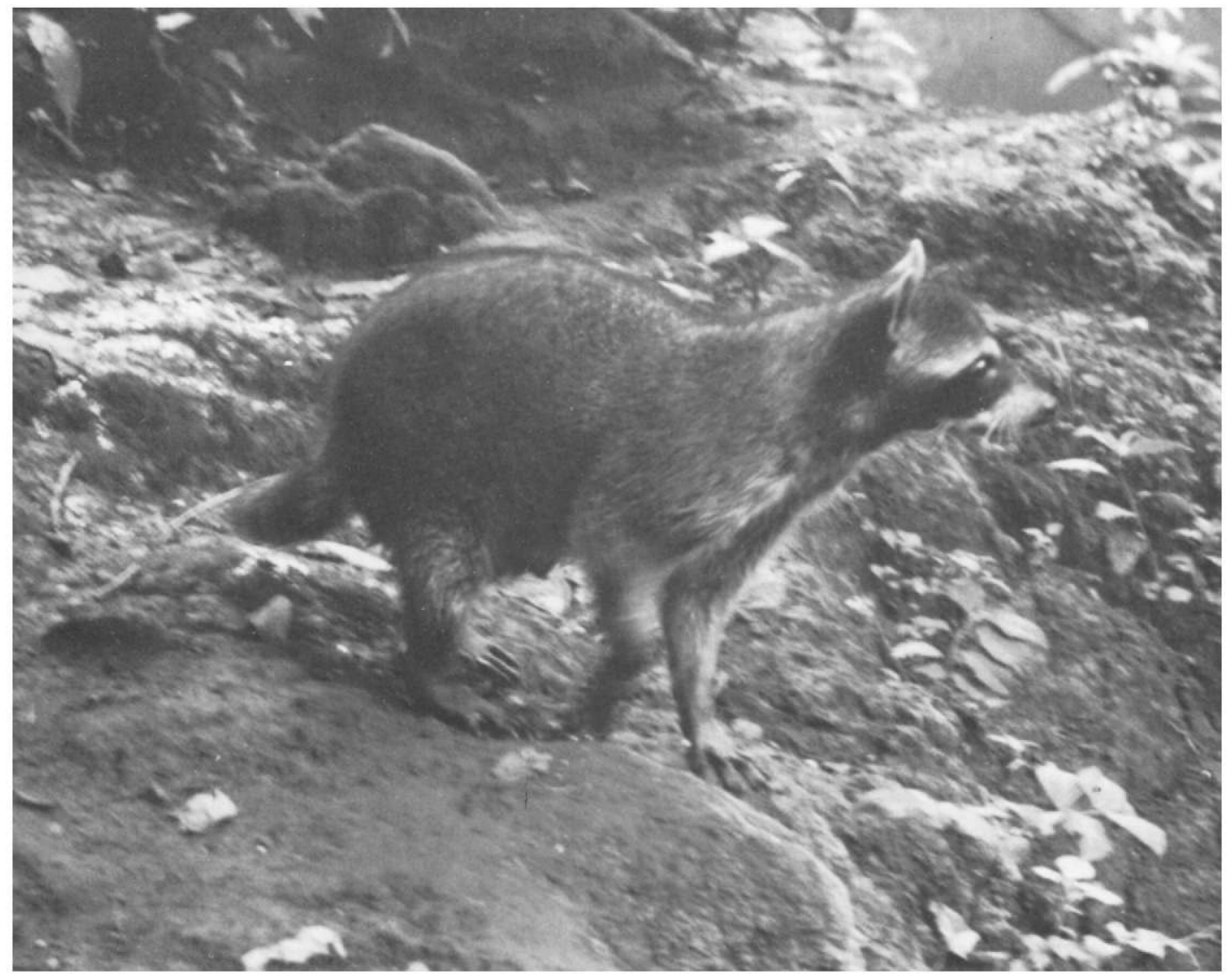

Fig. 105. Raccoon, Procyon lotor. Photo by R. M. Timm. 


\section{Eira barbara \\ Tayra, Tolomuco or Gato de Monte}

Tayras are found from Sinaloa and Tamaulipas, Mexico, south to northern Argentina (Fig. 106). Two subspecies are known from Costa Rica: Eira barbara biologiae from the southern and eastern part of the country and $E$. $b$. inserta from northern and western Costa Rica. Tayras are found from sea level to high-elevation cloud forest.

Tayras are the most arboreal and diurnal of the Neotropical mustelids. They are strong and agile climbers and frequently are seen during the day moving through the tree tops as well as on the ground. They eat small rodents, reptiles, and fruits, especially figs (Ficus). The biology of tayras in Costa Rica was reviewed recently by Janzen (1983c).

Tayras have been observed on several dozen occasions at La Selva. There are records of sightings from throughout the year. Judging from their close proximity in time and space, these records probably represent a few individuals seen repeatedly. Most sightings have been of lone animals. However, on 4-5 April 1982, an adult and a single young were observed together. Two observations are of two individuals together; three were observed together twice, and once five were seen together (14 June 1987). Many of the observations were made near buildings or on trails frequently traveled by researchers. Several sightings near El Sura in January 1987 were probably of the same individual. Hartshorn (in litt.) saw an adult and three juveniles in the pejibaye grove at La Selva in the early 1970's. A member of our group saw a tayra on two occasions near the 2,050-m camp in Braulio Carrillo, and another was seen at $200 \mathrm{~m}$.

Fig. 106. Tayra, Eira barbara. Photo by R. M. Timm. 


\section{Galictis vittata \\ Grison, Grisón or Tejón}

Grisons are found at lower elevations from central and eastern Mexico throughout Central America to Peru and southern Brazil (Fig. 107). The subspecies Galictis vittata canaster is found in Costa Rica from sea level to perhaps over $1,500 \mathrm{~m}$. Most records of grisons are from below $500 \mathrm{~m}$. In Costa Rica, however, grisons appear to be absent from the tropical dry forests of northwestern Costa Rica. They are uncommon and rarely observed throughout their range. Grisons should receive complete protection in Costa Rica as an endangered species.

Galictis vittata is found in a wide variety of habitats including both wet and dry tropical forests, open and wooded grasslands, and cultivated areas. Grisons are most often found near streams and rivers, and they swim readily. They are opportunistic predators and are known to prey on a variety of small mammals, including Didelphis and Sigmodon, lizards, snakes, frogs, and birds. Grisons are primarily nocturnal, although their activity may continue through the morning.

Grisons have been observed on nine occasions at La Selva. Although we have no record of this species from Braulio Carrillo, we expect that it occurs there.

Fig. 107. Grison, Galictis vittata. Photo by R. M. Timm.

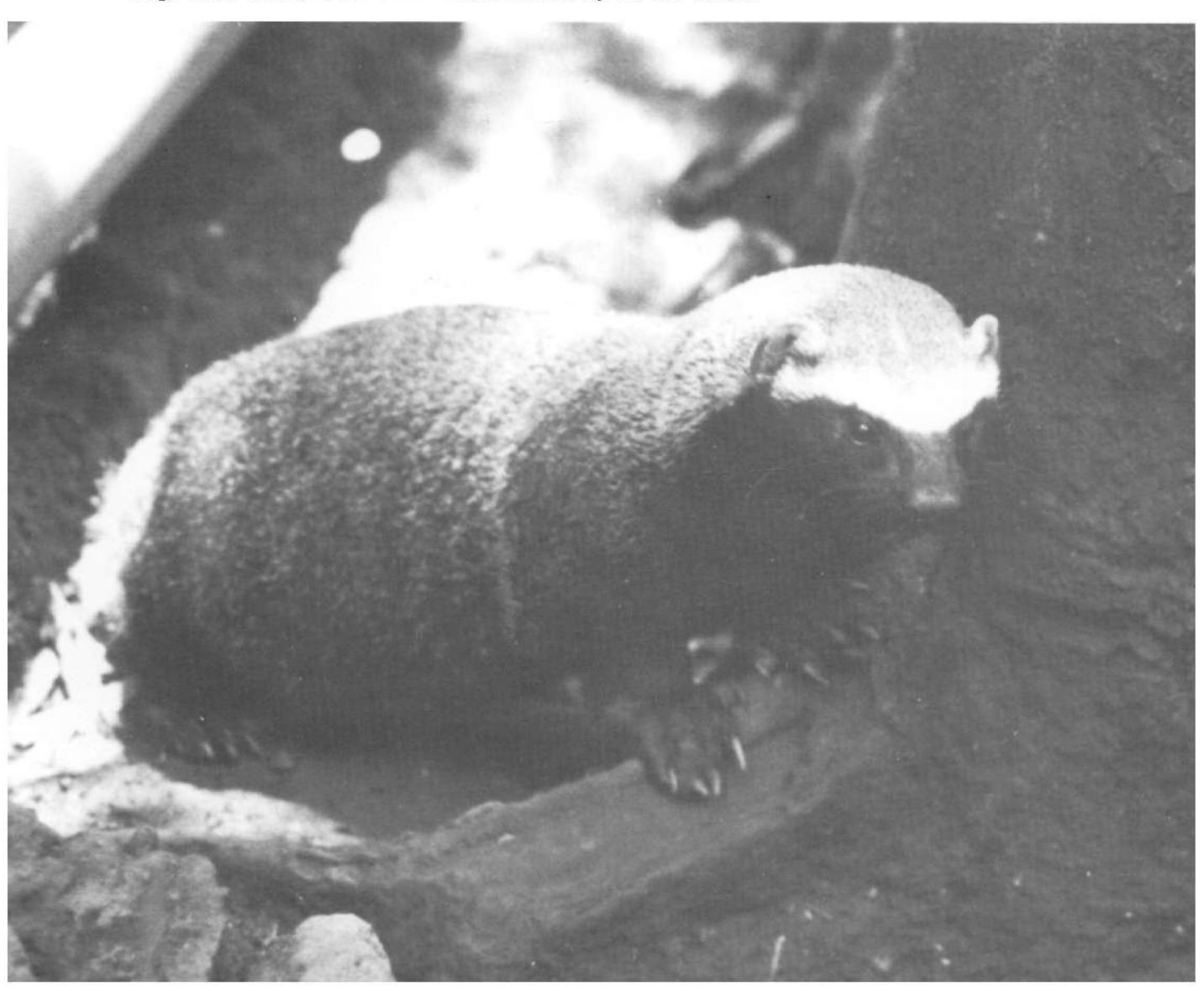




\section{Lutra longicaudis \\ Southern River Otter, Perro de Agua or Nutria}

Southern river otters are found from northwestern Mexico south through Central America to Peru and Uruguay. All otters in Costa Rica are now considered as belonging to the subspecies Lutra longicaudis annectens; however, there are few actual records for the country. A specimen collected by C. Underwood from Río Grande, Villa Colón, San José Province, was described by Cabrera (1924) as a distinct species, $L$. mesopetes. River otters are included on Costa Rica's listing of Rare and Endangered Species.

We found fresh otter scat on a rock in the Río Cantarrana at $300 \mathrm{~m}$; it contained the remains of crustaceans. Otters have been seen regularly at La Selva, primarily along the Río Puerto Viejo, Río Sarapiquí, and Quebrada El Salto. The 36 separate recordings of otters at La Selva (all but 5 have been of lone animals) include every month of the year. On several occasions in January 1987 and August 1988 we sighted two adult-sized individuals from the bridge over the Río Puerto Viejo. There is an otter den in the bluff of the Río Puerto Viejo about $300 \mathrm{~m}$ upstream from the station landing at La Selva.

\section{Mustela frenata \\ Long-tailed Weasel, Comadreja}

Long-tailed weasels are found from southern Canada through Central America to northern South America and along the Andes south to Bolivia (Fig. 108). The subspecies Mustela frenata costaricensis was described from San José, Costa Rica, and is now considered the subspecies that occurs throughout the country. There is little known about the distribution or ecology of weasels in Costa Rica. Longtailed weasels are abundant at middle and high elevations including the Monteverde area. The taxonomy of this weasel was last reviewed by Hall (1951).

Long-tailed weasels have been sighted on only three occasions at La Selva. In 1970, Wilson and Janzen captured one just west of Braulio Carrillo; Janzen kept it in captivity for several months. Near the city of Heredia we have observed longtailed weasels crossing roads between abandoned fields and in coffee plantations.

\section{Family Felidae}

\section{Felis concolor}

\section{Mountain Lion, Puma or León de Montaña}

Mountain lions are one of the most widely distributed mammals, originally found from Alaska across most of North America and throughout Central America and South America to Tierra del Fuego (Fig. 109). The subspecies Felis concolor costaricensis is distributed throughout Costa Rica but in reduced numbers because of hunting pressure. Mountain lions are rare in Costa Rica, although they are found in a variety of habitats from sea level to $3,300 \mathrm{~m}$. Mountain lions are included on both the Costa Rican and U.S. Rare and Endangered Species lists. The ecology of mountain lions, primarily based on studies in North America, was reviewed recently by Currier (1983). 


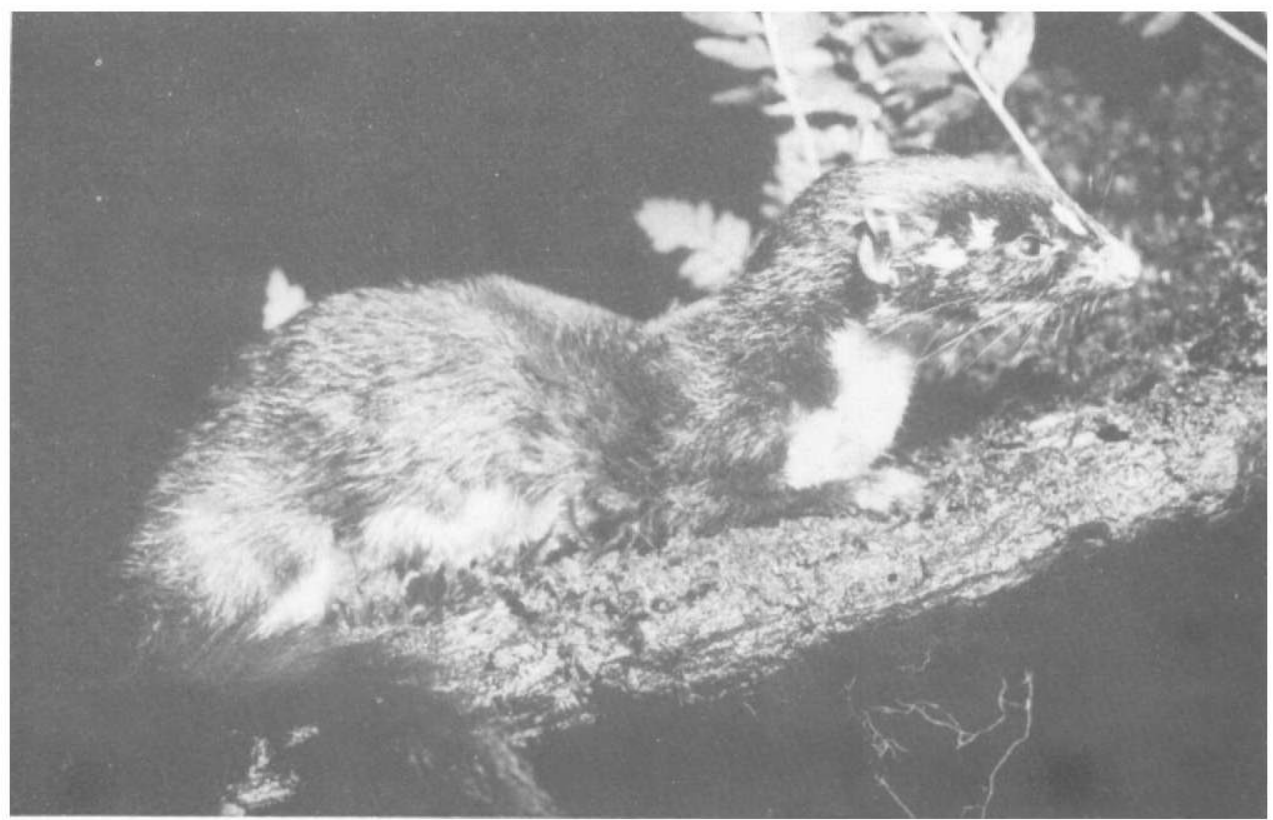

Fig. 108. Long-tailed weasel, Mustela frenata. Photo by B. L. Clauson.

Fig. 109. Mountain lion, Felis concolor. Photo by $R$. K. LaVal.

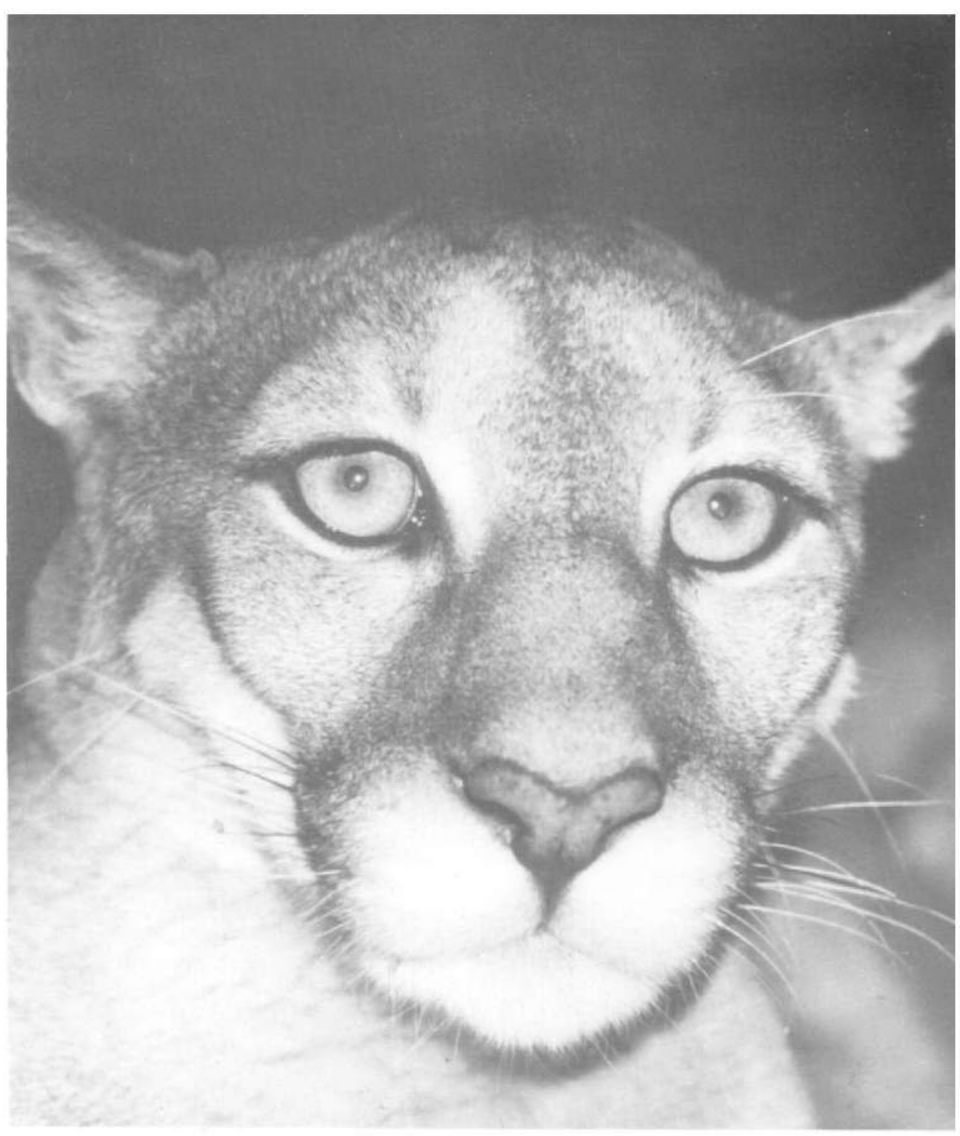


An adult mountain lion was seen crossing a trail near the Magsaysay guard station at $200 \mathrm{~m}$ in January 1986 by Reinaldo Aguilar Fernández, a park guard. A second mountain lion was seen at $1,000 \mathrm{~m}$ by a group on 21 February 1987 . Mountain lions have been observed on 12 occasions at La Selva. On one of these occasions, two adult-sized animals were sighted together. Hartshorn (in litt.) observed three mountain lions in Parque Nacional Braulio Carrillo along the Río Patria in 1986.

Specimen examined (1)-Moravia, Finca Tomás Guardia [1 male, UNA].

\section{Felis onca \\ Jaguar, Tigre}

Jaguars historically were found as far north as the Grand Canyon and California in the United States, through Mexico, all of Central America, and much of South America to northern Argentina (Fig. 110). In Costa Rica, the subspecies Felis onca centralis was once found from sea level to the higher forested elevations, although now its numbers and distribution have been reduced by hunting pressure and habitat destruction (Koford 1983a). Jaguars are included on both the Costa Rican and U.S. endangered species lists.

Jaguars are the largest terrestrial predators in the Neotropics. In Belize, armadillos, pacas, and brocket deer composed $94 \%$ of the diet of these nocturnal felids, although a wide variety of medium-sized mammals is consumed. There is extensive range overlap between males and females, but individuals are spaced within the territory to avoid contact with conspecifics except during the mating season. Males apparently use a small area for up to 2 weeks before shifting to another area (Rabinowitz and Nottingham 1986).

Jaguars have been seen eight times at La Selva. On several occasions, Vaughan tried unsuccessfully to capture and translocate a jaguar that had been killing livestock around Puerto Viejo since 1986. The local residents believe that it lives in La Selva. They have been seen at La Selva with increasing frequency in recent years. We found numerous large scats that we presume to be from a jaguar near the $2,050-\mathrm{m}$ camp. At La Selva we have twice identified the remains of tamanduas in the scats of jaguars, although sloths and green iguanas are the primary prey items found in jaguar scats there (Greene and Losos 1988). Park guards reported to us that a jaguar was observed just before our 1986 expedition at $200 \mathrm{~m}$ within the park. In the Zona Protectora, Pringle et al. (1984:198) reported that "We repeatedly encountered tracks of Felis onca (jaguar) throughout the ZP [Zona Protectora], and a fresh scat was observed on the trail east of the base camp."

\section{Felis pardalis \\ Ocelot, Manigordo or Ocelote}

Ocelots are found from the southern United States along the Pacific and Caribbean coasts of Mexico through much of Central America to northern Argentina. The subspecies Felis pardalis mearnsi is found in Costa Rica. Ocelots occur in a variety of habitats including dense forest, second growth, and agricultural areas, 


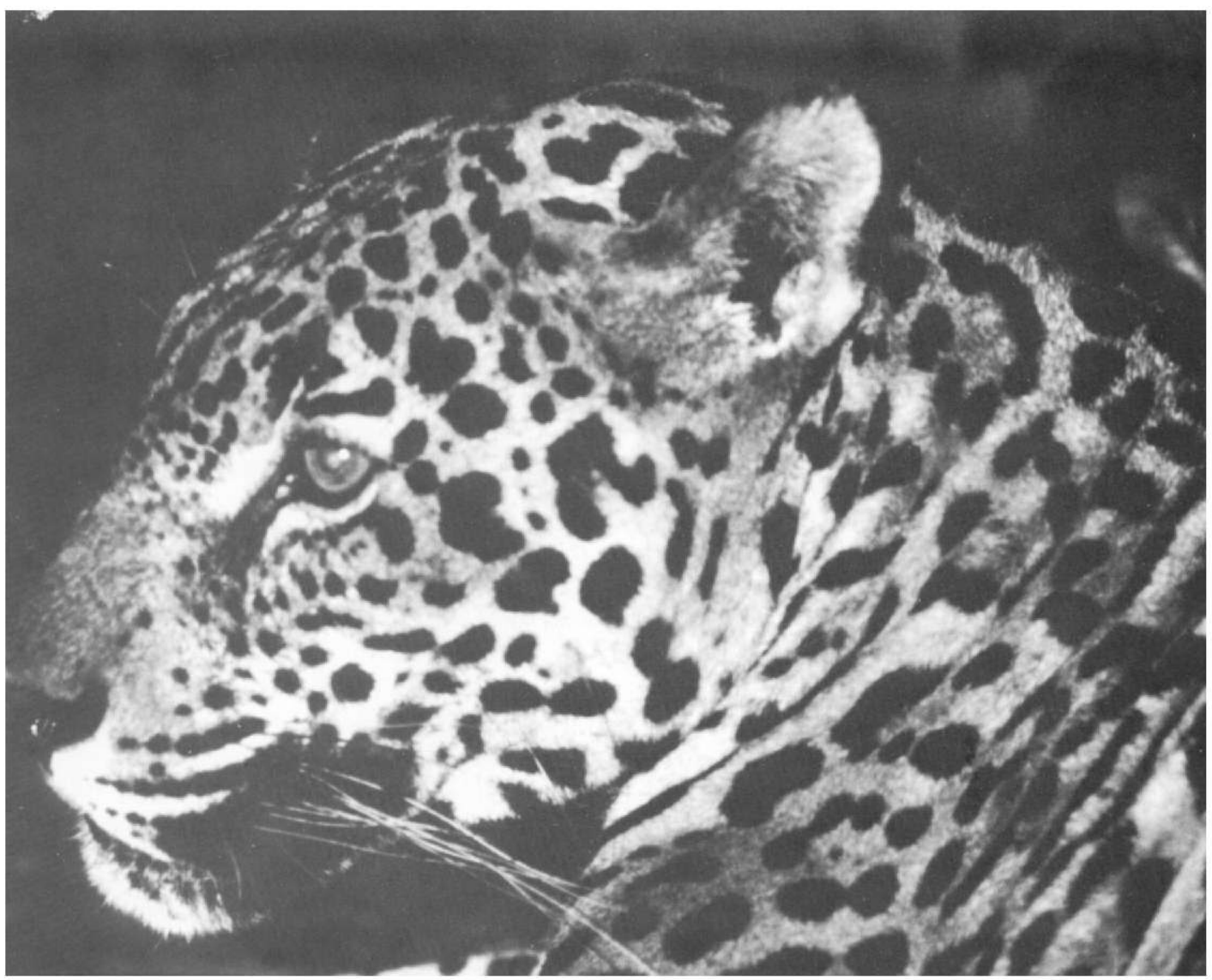

Fig. 110. Jaguar, Felis onca. Photo by $R$. K. LaVal.

where they range elevationally from sea level to nearly $3,800 \mathrm{~m}$. Ocelots are included on both the Costa Rican and U.S. listings of endangered species. Ocelots and jaguarundis are the most frequently observed native felids in Costa Rica.

Ocelots are primarily nocturnal and are not infrequently crepuscular. They eat a wide variety of small and medium-sized mammals, reptiles, and birds. Spiny rats (genus Proechimys), often abundant rodents in an area, are caught and eaten frequently by ocelots. In Peru, Emmons (1988) found that males and females were solitary and occupy distinct territories that are maintained by scent marks. Adult females had nonoverlapping home ranges as did males. Male territories, however, overlapped those of three or more adult females.

We observed the tracks or scats of ocelots at $760 \mathrm{~m}, 2,000 \mathrm{~m}$, and at $2,610 \mathrm{~m}$ within Parque Nacional Braulio Carrillo. Ocelots have been observed at La Selva on 17 occasions. 


\section{Felis wiedii \\ Margay, Caucél}

Margays originally were found from the southwestern United States through Central and South America to northern Argentina (Fig. 111). The subspecies Felis wiedii nicaraguae formally occurred throughout Costa Rica from sea level to the higher elevations (Koford 1983b). Margays are included on both the Costa Rican and U.S. listings of endangered species.

Margays are arboreal predators. In Belize, M. J. Konecny (in litt.) found that the diet of this diminutive cat was primarily smaller arboreal rodents.

Margays have been seen at La Selva on only three occasions, in February 1982, in June 1986, and in March 1988.

\section{Felis yagouaroundi \\ Jaguarundi, León Breñero or Gatillo de Monte}

Jaguarundis originally ranged from the southwestern United States through Central America to northern Argentina. The subspecies Felis yagouaroundi panamensis is distributed throughout Costa Rica in suitable habitat along both coasts to $2,000 \mathrm{~m}$ in elevation. Jaguarundis are one of the smallest and most variably colored felids in this region, with color phases ranging from grays and deep reddishbrowns to blacks. Jaguarundis are included on both the Costa Rican and U.S. listings of endangered species.

Jaguarundis are perhaps the most diurnal of the Neotropical cats, and they are also the most adaptable, occurring in primary and secondary forests as well as in pastures. Small mammals, especially Sigmodon spp. and birds, made up most of the prey items of jaguarundis in Belize (Konecny, in litt.).

Jaguarundis have been observed at La Selva on 25 occasions with records from most months. An adult with four kittens was seen in July 1985. An adult was observed stalking a spiny rat on the Sura bridge in February 1983.

Fig. 111. Margay, Felis wiedii. Photo by R. K. LaVal.

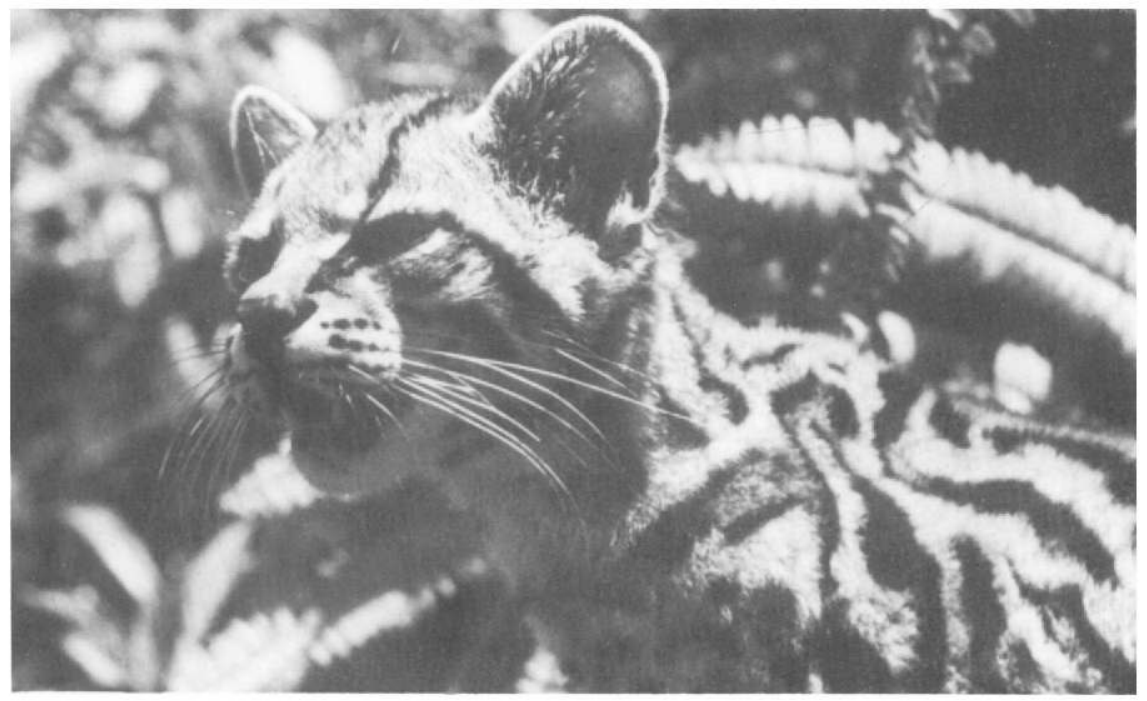




\title{
ORDER PERISSODACTYLA
}

\author{
Family Tapiridae \\ Tapirus bairdii \\ Baird's Tapir, Danta
}

Baird's tapir (Tapirus bairdii) originally was found from southern Mexico east of the Isthmus of Tehuantepec south throughout Central America to the western slopes of the Andes in Colombia and Ecuador to the Gulf of Guayaquil (Fig. 112). Tapirs probably were common throughout most of Costa Rica before contact by Europeans. There are no recognized subspecies of Baird's tapir. In Costa Rica, tapirs are found in a wide variety of habitats from sea level to $3,800 \mathrm{~m}$. They seem to require large tracts of primary forest and protection from hunting pressure in order to maintain adequate population levels (Janzen 1983d). Baird's tapir is included on both the Costa Rican and U.S. listings of rare and endangered species. The biology of tapirs in northwestern Costa Rica was investigated by Williams (1984).

We observed tapir tracks and droppings at several localities within Parque Nacional Braulio Carrillo, ranging from 100 to 2,000 m in elevation. Tracks were most common in the elevational range from 1,500 to $2,000 \mathrm{~m}$. A single individual was observed at $1,800 \mathrm{~m}$ in February 1987 . Tapirs were reported by Pringle et al. (1984) from the southern end of the Zona Protectora at $700 \mathrm{~m}$ in January 1983. Tapir tracks are seen regularly at La Selva, but the animals are rarely observed; most have been seen near the south end of the property. Slud (1960) implied that tapirs were common there in the late 1950's.

Fig. 112. Baird's tapir, Tapirus bairdii. Photo by B. L. Clauson.

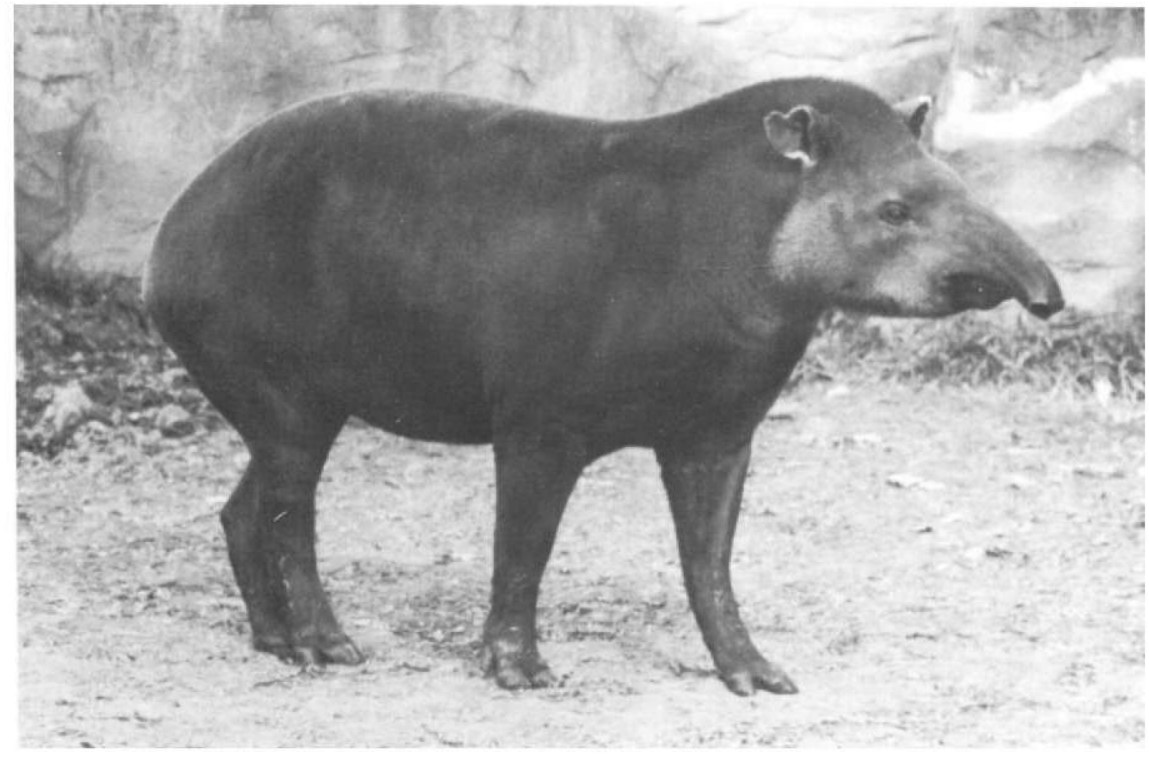




\section{ORDER ARTIODACTYLA}

\section{Family Tayassuidae \\ Tayassu pecari \\ White-lipped Peccary, Chancho de Monte}

White-lipped peccaries once occurred in lowland tropical forests from Veracruz and Oaxaca in southern Mexico through Central America and much of tropical South America to Entre Ríos in northern Argentina (Fig. 113). One subspecies, Tayassu pecari spiradens, is found in Costa Rica; the type locality for this subspecies is Sipurio, Río Sixaola, Limon Province. This species is a wilderness species and endangered in Costa Rica due to overexploitation and habitat destruction (Vaughan 1983a). It is found from sea level to $1,500 \mathrm{~m}$. There has been little work on whitelipped peccaries in Costa Rica, in part because they are now so rarely encountered. The ecology of this species recently was reviewed by Mayer and Wetzel (1987).

Between 1979 and 1987, herds of white-lipped peccaries have been recorded at La Selva on only five occasions, the most recent of these in July 1983. Pringle et al. (1984:198) reported, "Local people told us that white-lipped peccaries ( $T$. pecari) were especially vulnerable to overhunting because of large herd size and aggressive temperament, and that this species is now very rare or absent in the ZP [Zona Protectora]." McHargue and Hartshorn (1983:401) stated of $T$. pecari in the La Selva area that "According to knowledgeable local people, white-lipper. peccaries are usually found in swamps feeding on Carapa seeds. We did not observe any sign of white-lipped peccaries in the Study Area II during the summers of 1974, 1975, and 1976." White-lipped peccaries apparently were abundant in the La Selva area as late as the early 1960's. Paul Slud (1960:76) wrote "Ominous are the clopping, champing noises of a herd of White-lipped Peccaries; unsettling is the heavy, growling 'woof' of a startled individual close at hand."

Although white-lipped peccaries have been given complete protection as an endangered species in Costa Rica, the species is still hunted in some areas.

\section{Tayassu tajacu Collared Peccary, Saíno}

Collared peccaries are found from the southwestern United States throughout Central America and tropical South America south to Santiago del Estero in northern Argentina (Fig. 114). One subspecies, Tayassu tajacu crusnigrum is found in Costa Rica from sea level to about $3,000 \mathrm{~m}$. Collared peccaries are one of the most important game species in Costa Rica.

Collared peccaries are common, obvious elements of the La Selva fauna; they have been seen there on numerous occasions year round. They have been observed in herd sizes of 25-30 individuals. Juveniles have been seen in May and July. The January 1983 and the 1986 expeditions into Braulio Carrillo recorded peccary tracks at numerous elevations. Although the tracks could not be identified to species, it 


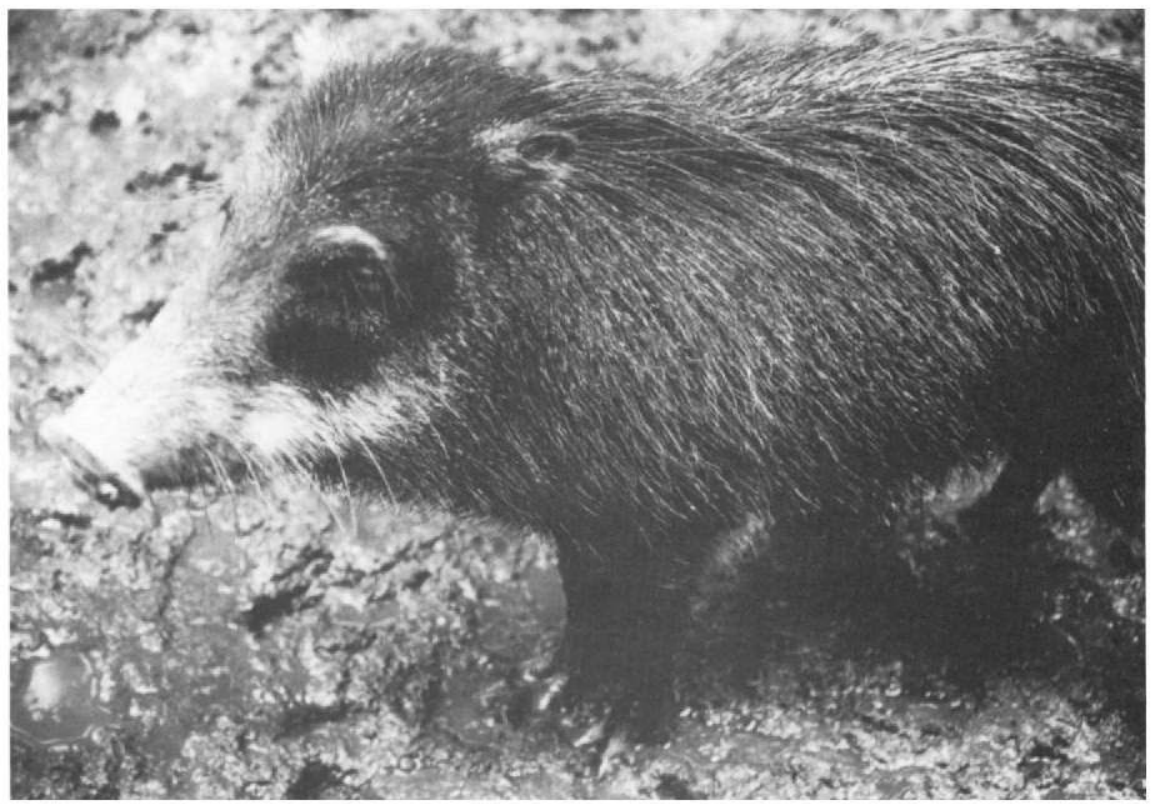

Fig. 113. White-lipped peccary, Tayassu pecari. Photo by B. L. Clauson.

Fig. 114. Collared peccary, Tayassu tajacu. Photo by N. Woodman.

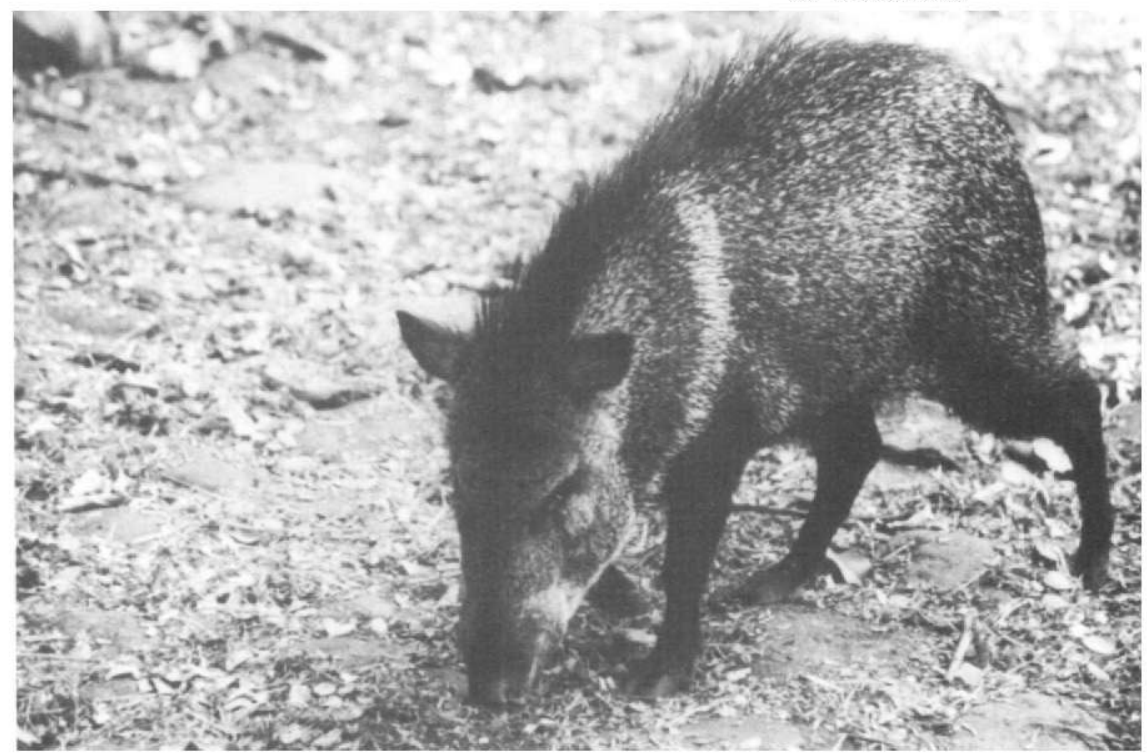


is likely they were from collared peccaries. Our group sighted collared peccaries at $200 \mathrm{~m}$ and again at $300 \mathrm{~m}$.

At La Selva in August 1988, we observed damage to stems of the large terrestrial aroid, Dieffenbachia sp. (Araceae), caused by peccaries feeding on it. As the sap of diffenbachias, and especially this species, contains large amounts of raphides of water-insoluble calcium oxalate crystals and cyanogenic glycosides, this observation is of interest. Because of the high concentrations of these extremely noxious chemicals found in the sap, few insects or vertebrates are able to feed on Dieffenbachia. The peccaries seemed to have fed only on the older diffenbachias in which the main stem trailed along the ground. Damage caused by peccaries was noted only on the lowest, horizontal sections of the stem; there was no evidence of feeding on vertical stems. In the northern, arid parts of their range, T. tajacu is known to feed on several species of prickly-pear cactus (genus Opuntia), which also contain oxalic acid, a substance that is toxic to most mammals (Sowls 1983). Thus, peccaries seem to be one of the few animals that are capable of utilizing plants with high oxalate concentrations.

\section{Family Cervidae \\ Mazama americana Red Brocket, Cabro de Monte}

Red brocket deer are found from eastern Mexico through Central and tropical South America to Bolivia and Paraguay. In Costa Rica, the subspecies Mazama americana cerasina is found throughout the country, although there are few actual records. It frequents forested areas from sea level to near timber line.

We saw tracks of brocket deer at $2,100 \mathrm{~m}$ and skulls of this species were seen at a cabin at $2,000 \mathrm{~m}$; presumably these individuals were shot nearby. Brocket deer have been recorded at La Selva on 12 occasions. Tracks of brocket deer in the Zona Protectora were reported by Pringle et al. (1984).

\section{Odocoileus virginianus \\ White-tailed Deer, Venado Cola Blanca}

Two subspecies of white-tailed deer are found in Costa Rica: Odocoileus virginianus chiriquensis in the southwest and $O . v$. truei throughout the rest of the country (Fig. 115). White-tailed deer are found from sea level to at least $1,300 \mathrm{~m}$.

There are 21 observations of white-tailed deer at La Selva where they have been recorded from nearly every month of the year. A female with a fawn was observed in January 1984 and a female and two half-grown young were sighted in September 1985. Janzen (1983e) reviewed natural history information for Costa Rica. 


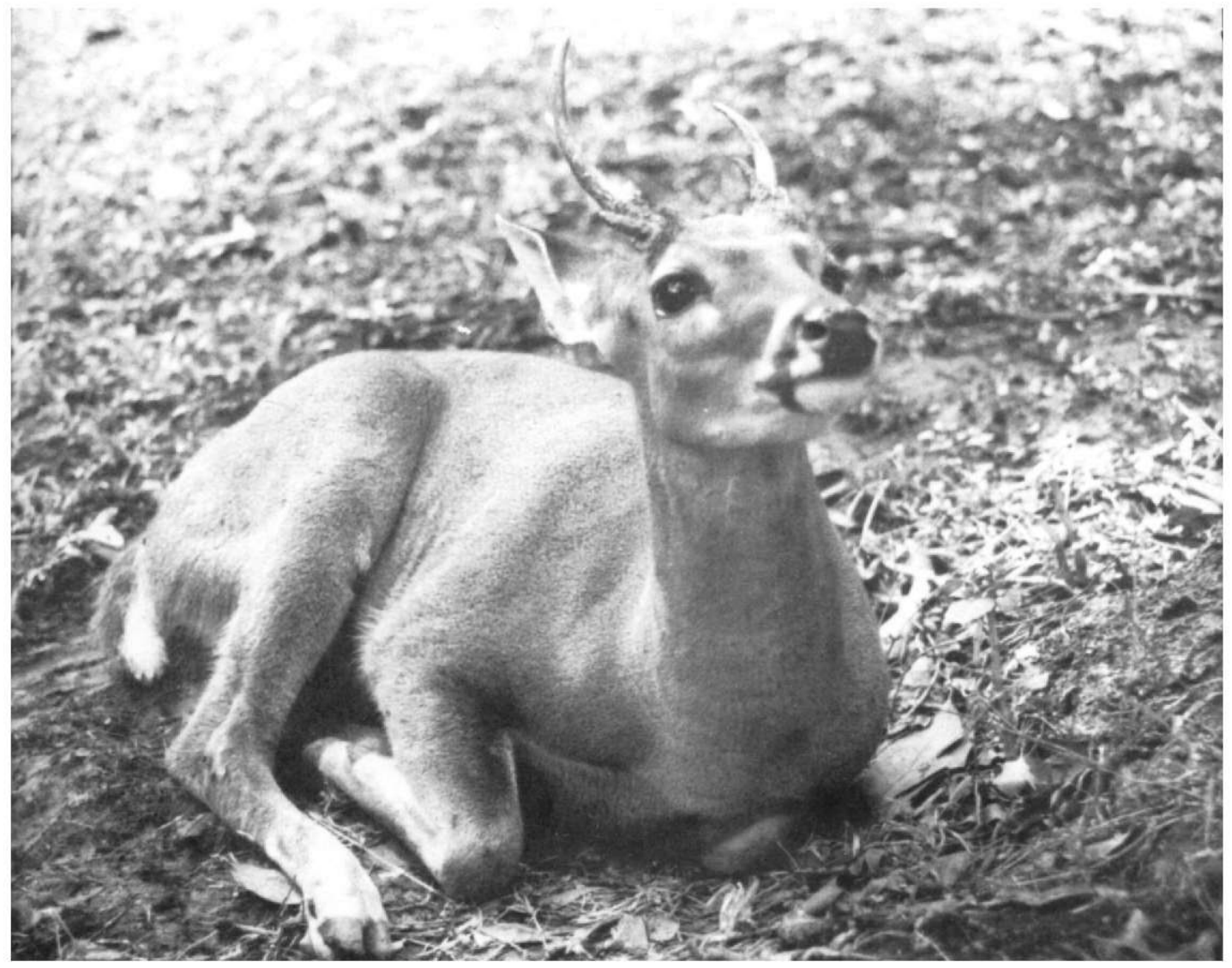

Fig. 115. White-tailed deer, Odocoileus virginianus. Photo by B. L. Clauson.

\section{Species Extirpated from the Park}

\section{Myrmecophaga tridactyla \\ Giant Anteater, Oso Caballo}

Giant anteaters originally were found from Guatemala and Belize throughout the tropical lowlands of Central America and tropical South America to southwestern Brazil (Fig. 116). The subspecies Myrmecophaga tridactyla centralis was found in Central America, but its range is now much reduced due to overhunting and habitat destruction. There are few records or observations of giant anteaters from this region, and we suspect that this species is either extirpated from this area as it is from much of the country, or that population numbers are so low that the population cannot be considered viable. 


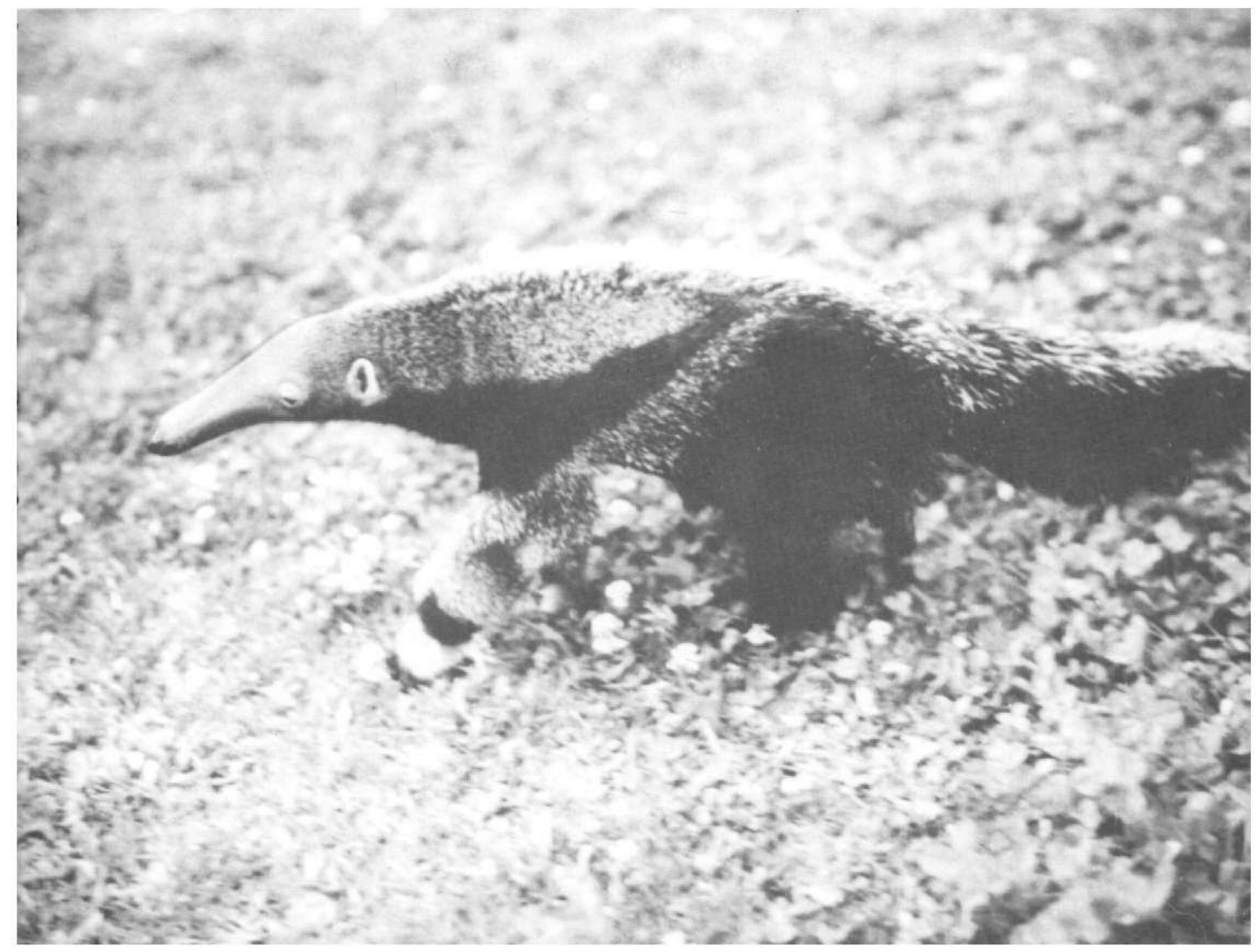

Fig. 116. Giant anteater, Myrmecophaga tridactyla. Photo by B. L. Clauson.

In late 1978 or early 1979 McDade observed a large, dark animal at La Selva that she believed was a giant anteater. She noted that it was at least $75 \mathrm{~cm}$ high at the shoulders, had a very long and coarsely bushy tail, and had a flash of white near the front legs. It was seen on the River Road Trail between the Quebrada El Sura bridge and the old field station. She saw it on the trail and as it loped into the forest (McDade, personal communication). The only other recent observation of a giant anteater in Costa Rica was one seen near the Sirena field station at Parque Nacional Corcovado on the Osa Peninsula. Boinski saw one at close range while it foraged in maturing second growth forest in 1979 (Boinski, personal communication). On two or three other occasions she observed diggings in termite mounds that she attributed to $M$. tridactyla.

We know little about the original distribution and abundance of giant anteaters in Costa Rica. The first, and one of the few, authors to mention giant anteaters in the country was Alston (1879-82) who reported that they were considered rare in Costa Rica and confined to the "low hot forest lands near the coast," This species 
has experienced severe reduction in numbers and range since colonization of the Neotropics by European man.

\section{Species of Possible or Probable Occurrence in the Area}

\section{Diclidurus albus \\ Ghost Bat}

Ghost bats are found from Nayarit, Mexico, to eastern Brazil. The subspecies Diclidurus albus virgo is found in Costa Rica. Although some authors consider $D$. virgo (type locality, Escazú, Costa Rica) a species distinct from $D$. albus, we follow Honacki et al. (1982) in regarding the Central American populations as a subspecies of the widely distributed $D$. albus.

Relatively little published information is available on the natural history of ghost bats. Most of the few specimens of $D$. albus in collections have been shot in flight or from roosting sites under palm leaves (Sánchez and Chávez 1984). In Venezuela, Handley (1976) found them in a variety of habitats. This species is insectivorous. The reproductive cycle seems to be monestrous, and breeding aggregations suggesting harems have been reported (Sánchez and Chávez 1984). Although there are no specimens of ghost bats from the La Selva area, we suspect that it occurs there.

Underwood collected the first Costa Rican specimen at Escazú in 1897 (Goodwin 1946). The biology of ghost bats was reviewed by Ceballos and Medellín (1988).

\section{Aotus lemurinus \\ Night Monkey, Mono Nocturno}

Night monkeys of the genus Aotus are widespread in the lowlands of South America and previously were known as far north as Isla Bastimentos, Bocas del Toro Province, Panama. A historical record of an Aotus collected in Costa Rica in the early 1870's has long been discounted, as has one from Bluefields, Nicaragua. However, in a recent review of this literature, Timm (1989) suggested that the Costa Rican specimen might be a valid record. Previous authors have attributed this specimen to a locality variously spelled Quindín, Quindin, or Quindiu. This locality (actually in Colombia) was erroneously applied to the specimen by Elliott some 45 years after the specimen was collected. Several recent observations between 1975 and 1986 suggest that $A$. lemurinus may be present in the Caribbean lowlands of Costa Rica (Timm 1989). Night monkeys apparently have been sighted on three occasions at the La Selva Biological Reserve, and hunters have reported night monkeys near that area and also near Bribri, Limón Province, near the Panamanian border. Although the presence of night monkeys in Costa Rica still needs to be confirmed, the species should be sought in appropriate habitats throughout the Caribbean lowlands. 


\section{Sciurus deppei \\ Deppe's Squirrel, Ardilla de Miravalles or Chiza Negra}

Deppe's squirrel is found from Tamaulipas and Veracruz of eastern Mexico to northern Costa Rica. A single subspecies, Sciurus deppei miravallensis, has been described from Costa Rica; the type locality is Volcán de Miravalles in the Cordillera de Guanacaste at $1,500 \mathrm{ft}$ (Harris 1931, 1943). The distribution of this squirrel in Costa Rica is poorly understood. We have observed it throughout much of the Guanacaste lowlands of northwestern Costa Rica and at Monteverde, where it is quite abundant.

Although the only published records of this squirrel are from extreme northwestern Costa Rica (McPherson 1985), squirrels identified as $S$. deppei have been recorded at La Selva on several occasions. We cannot confirm that $S$. deppei occurs as far east and south in Costa Rica as La Selva; however, we suspect that this species is more widely distributed in the country than believed previously.

\section{Oryzomys couesi \\ Coues' Marsh Rice Rat, Ratón}

Coues' marsh rice rat is found from southern Texas and eastern Mexico to the Caribbean lowlands of extreme northern Colombia (Hershkovitz 1987). The systematic position of Oryzomys couesi has long been in a state of flux. It was originally proposed as a full species based on specimens taken in Guatemala; however, Hall (1960) suggested that the populations known as couesi from Central America intergraded with $O$. palustris to the north and were best considered a subspecies of $O$. palustris. Recent karyologic studies have demonstrated that $O$. couesi has a large submetacentric $\mathrm{X}$ chromosome, whereas $O$. palustris has a large acrocentric X; both have a diploid number of 56 (Benson and Gehlbach 1979). Both karyotypes are known from Texas and Mexico which suggests that two species are involved, although they have not been obtained from the same locality.

Although no specimens of this species have been observed at La Selva or in Braulio Carrillo, it seems likely that $O$. couesi does occur there because it is widely distributed throughout the Caribbean lowlands of Central America and has been collected at several localities in the Caribbean lowlands of Costa Rica. Rice rats are often abundant in cultivated fields and in weedy gardens.

\section{Urocyon cinereoargenteus Gray Fox, Tigrillo or Zorra Gris}

Gray foxes are among the most widely distributed of the New World carnivores, being found from southern Canada across most of the United States (except for the northwestern States) through Mexico and Central America to northern Colombia and Venezuela. Little has been published on the distribution or ecology of gray foxes in the tropics. They may be found throughout the middle and higher elevations of Costa Rica. They appear to be most common in altered habitats. Although 
we have no records of gray foxes from Parque Nacional Braulio Carrillo, we suspect that they occur there. Apparently these foxes are found throughout the country except for the Atlantic lowlands. The biology of gray foxes, based primarily on studies in the eastern United States, recently was reviewed by Fritzell and Haroldson (1982).

\section{Acknowledgments}

We are pleased to thank the Servicio de Parques Nacionales, especially F. Cortés and the many park guards, for making our studies in Parque Nacional Braulio Carrillo possible, profitable, and enjoyable. E. López Pizarro and G. Canessa Mora of the Departamento Vida Silvestre facilitated permits for our work. The Organization for Tropical Studies, especially R. Butterfield, G. S. Hartshorn, L. A. McDade, and C. E. Schnell went above and beyond the call of duty to provide first-rate and indispensable logistic assistance. Funding for this project was provided by the Field Museum of Natural History, National Geographic Society, Organization for Tropical Studies, Rice Foundation of Chicago (we especially thank Mr. and Mrs. A. A. Nolan, Jr.), and Universidad Nacional de Costa Rica. We are extremely grateful to each of these organizations for making our studies possible. We heartily thank R. Aguilar F., J. S. Ashe, R. J. Izor, D. G. Pranke, and J. H. Shook, Jr., for providing excellent technical and logistic assistance in the field, often under trying conditions. R. L. Wenzel provided us with the identifications of the bat flies we collected, and J. E. Keirans provided us with the identifications of the ticks. S. Boinski, A. P. Brooke, G. Hartshorn, D. H. Janzen, and L. McDade freely shared their unpublished observations on mammals with us. J. Rodriguez (University of Costa Rica), S. B. George (Natural History Museum of Los Angeles County), J. S. Findley and T. L. Yates (University of New Mexico), J. K. Jones, Jr. and R. D. Owen (Texas Tech University), P. Myers (University of Michigan), B. D. Patterson (Field Museum of Natural History), D. A. Schlitter (Carnegie Museum of Natural History), and B. Stein and J. L. Patton (Museum of Vertebrate Zoology) were extremely helpful in making specimens housed in their respective collections available to us for study. J. K. Adams, A. L. Gardner, J. Hoth, R. W. McDiarmid, C. Thorington, M. D. Tuttle, and $\mathrm{N}$. Woodman provided us with some of the photographs that are published here. We especially thank J. Wiglesworth for her efforts in expeditiously and cheerfully typing the numerous drafts of this manuscript. M. A. Bogan, G. K. Creighton, A. L. Gardner, G. S. Hartshorn, J. K. Jones, Jr., L. A. McDade, P. A. Opler, D. E. Stone, and N. Woodman provided us with valuable suggestions on earlier drafts. We appreciate the care and expertise A. M. Musser used in drafting the map (Fig. 1). 


\section{References}

Adams, J. K. 1989. Pteronotus davyi. Mamm. Species. 346:1-5.

Albuja V., L. 1983. Murciélagos del Ecuador. Escuela Politécnica Nac., Depto. Cien. Biol., Quito, Ecuador. xii + 285 pp. + map.

Alfaro, A. 1897. Mamíferos de Costa Rica. Museo Nacional, San José. 51 pp.

Allen, G. M., and T. Barbour. 1923. Mammals from Dariên. Mus. Comp. Zool. Harv. Bull. 65:259-274.

Allen, H. 1892. Description of a new genus of phyllostome bats. Proc. U.S. Natl. Mus. Bull. 15(913):441-442.

Allen, H. 1898. The skull and teeth of Ectophylla alba. Trans. Am. Philos. Soc. 19:267-273.

Allen, J. A. 1892. Further notes on Costa Rican mammals, with descriptions of a new species of Oryzomys. Bull. Am. Mus. Nat. Hist. 5:237-240.

Allen, J. A. 1897. Additional notes on Costa Rican mammals, with descriptions of new species. Bull. Am. Mus. Nat. Hist. 9:31-44.

Alston, E. R. 1879-1882. Biologia Centrali-Americana, Mammalia. Taylor and Francis, London. $x x+220$ pp. +22 plates.

Alvarez, T. 1968. Notas sobre una colección de mamíferos de la región costera del Río Balsas entre Michoacán y Guerrero. Rev. Soc. Mex. Hist. Nat. 29:21-35.

Anthony, H. E. 1923. Preliminary report on Ecuadorean mammals, No. 3. Am. Mus. Novit. $55: 1-14$.

Armstrong, D. M. 1969. Noteworthy records of bats from Costa Rica. J. Mammal. 50:808-810.

Baker, R. J., and C. L. Clark. 1987. Uroderma bilobatum. Mamm. Species 279:1-4.

Baker, R. J., J. C. Patton, H. H. Genoways, and J. W. Bickham. 1988. Genic studies of Lasiurus (Chiroptera: Vespertilionidae). Occas. Pap. Mus. Tex. Tech Univ. 117:1-15.

Belt, T. 1874. The naturalist in Nicaragua. John Murray, London. 403 pp. [1985 reprint, University of Chicago Press, Chicago]

Benson, D. L., and F. R. Gehlbach. 1979. Ecological and taxonomic notes on the rice rat (Oryzomys couesi) in Texas. J. Mammal. 60:225-228.

Bonaccorso, F. J. 1979. Foraging and reproductive ecology in a Panamanian bat community. Bull. Fla. State Mus. Bio. Sci. 24(4):359-408.

Bradbury, J. 1983a. Saccopteryx bilineata (murciélago de saco, sac-wing bat). Pages 488-489 in D. H. Janzen, ed. Costa Rican natural history. University of Chicago Press, Chicago. $816 \mathrm{pp}$.

Bradbury, J. 1983b. Vampyrum spectrum (vampiro falso, false vampire bat). Pages 500-501 in D. H. Janzen, ed. Costa Rican natural history. University of Chicago Press, Chicago. 816 pp.

Bradbury, J. W., and S. L. Vehrencamp. 1976. Social organization and foraging in emballonurid bats. I. Field studies. Behav. Ecol. Sociobiol. 1:337-381.

Bradbury, J. W., and S. L. Vehrencamp. 1977. Social organization and foraging in emballonurid bats. IV. Parental investment patterns. Behav. Ecol. Sociobiol. 2:19-29.

Brandon, C. 1983. Noctilio leporinus (murciélago pescador, fishing bulldog bat). Pages 480-481 in D. H. Janzen, ed. Costa Rican natural history. University of Chicago Press, Chicago. $816 \mathrm{pp}$.

Brooke, A. P. 1987a. Tent construction and social organization in Vampyressa nymphaea (Chiroptera: Phyllostomidae) in Costa Rica. J. Trop. Ecol. 3:171-175.

Brooke, A. P. 1987b. The natural history of the Honduran white bat, Ectophylla alba, in Costa Rica. M.A. thesis, Boston University, Mass. $90 \mathrm{pp}$.

Brooke, A. P. 1988. Prey selection, foraging and habitat use by Chrotopterus auritus in Costa Rica. Bat Res. News 29(4):44. 
Bucher, J. E., and R. S. Hoffmann. 1980. Caluromys derbanius. Mamm. Species 140:1-4. Cabrera, A. 1924. Una nueva nutria de la América Central. Bol. Real Soc. Española Hist. Nat. 24:52-53.

Carter, D. C., R. H. Pine, and W. B. Davis. 1966. Notes on Middle American bats. Southwest. Nat. 11:488-499.

Casebeer, R. S., R. B. Linsky, and C. E. Nelson. 1963. The phyllostomid bats, Ectophylla alba and Vampyrum spectrum, in Costa Rica. J. Mammal. 44:186-189.

Ceballos, G., and R. A. Medellín. 1988. Diclidurus albus. Mamm. Species 316:1-4.

Choate, J. R. 1970. Systematics and zoogeography of Middle American shrews of the genus Cryptotis. Univ. Kans. Publ. Mus. Nat. Hist. 19(3):195-317.

Currier, M. J. P. 1983. Felis concolor. Mamm. Species 200:1-7.

Davis, D. R., D. H. Clayton, D. H. Janzen, and A. P. Brooke. 1986. Neotropical Tineidae, II: Biological notes and descriptions of two new moths phoretic on spiny pocket mice in Costa Rica (Lepidoptera: Tineoidea). Proc. Entomol. Soc. Wash. 88:98-109.

Davis, W. B. 1965. Review of the Eptesicus brasiliensis complex in Middle America with the description of a new subspecies from Costa Rica. J. Mammal. 46:229-240.

Davis, W. B. 1966. Review of South American bats of the genus Eptesicus. Southwest. Nat. 11:245-274.

Davis, W. B. 1980. New Sturnira (Chiroptera: Phyllostomidae) from Central and South America, with key to currently recognized species. Occas. Pap. Mus. Tex. Tech Univ. 70:1-5.

Davis, W. B. 1984. Review of the large fruit-eating bats of the Artibeus "lituratus"' complex (Chiroptera: Phyllostomidae) in Middle America. Occas. Pap. Mus. Tex. Tech Univ. 93:1-16.

Davis, W. B., and D. C. Carter. 1962. Notes on Central American bats with description of a new subspecies of Mormoops. Southwest. Nat. 7:64-74.

Davis, W. B., and D. C. Carter. 1978. A review of the round-eared bats of the Tonatia silvicola complex. Occas. Pap. Mus. Tex. Tech Univ. 93:1-16.

Davis, W. B., D. C. Carter, and R. H. Pine. 1964. Noteworthy records of Mexican and Central American bats. J. Mammal. 45:375-387.

de la Torre, L. 1961. The evolution, variation, and systematics of the Neotropical bats of the genus Sturnira. Ph.D. dissertation, University of Illinois. 143 pp.

Diersing, V. E. 1981. Systematic status of Sylvilagus brasiliensis and S. insonus from North America. J. Mammal. 62:539-556.

Dinerstein, E. 1986. Reproductive ecology of fruit bats and the seasonality of fruit production in a Costa Rican cloud forest. Biotropica 18:307-318.

Dobson, G. E. 1878. Catalogue of the Chiroptera in the collection of the British Museum. Br. Mus. (Nat. Hist.), London. 576 pp.

Dolan, P. G. 1982. Systematics of Middle American mastiff bats (Molossus). Ph.D. dissertation, Texas Tech University. viii $+151 \mathrm{pp}$.

Eisenberg, J. F. 1983. Ateles geoffroyi (mono araña, mono colorado, spider monkey). Pages 451-453 in D. H. Janzen, ed. Costa Rican natural history. University of Chicago Press, Chicago. 816 pp.

Emmons, L. H. 1988. A field study of ocelots (Felis pardalis) in Peru. Rev. Ecol. (Terre Vie) 43:133-157.

Findley, J. S., and D. E. Wilson. 1974. Observations on the Neotropical disk-winged bat, Thyroptera tricolor Spix. J. Mammal. 55:562-571.

Findley, J. S., and D. E. Wilson. 1983. Are bats rare in tropical Africa? Biotropica 15:299-303.

Fishkind, A. S., and R. W. Sussman. 1987. Preliminary survey of the primates of the Zona Protectora and La Selva Biological Station, northeast Costa Rica. Primate Conserv. 8:63-66.

Fleming, T. H. 1973. The number of rodent species in two Costa Rican forests. J. Mammal. 54:518-521. 
Fleming, T. H. 1974a. The population ecology of two species of Costa Rican heteromyid rodents. Ecology 55:493-510.

Fleming, T. H. 1974b. Social organization in two species of Costa Rican heteromyid rodents. J. Mammal. 55:543-561.

Fleming, T. H. 1977a. Growth and development of two species of tropical heteromyid rodents. Am. Midl. Nat. 98:109-123.

Fleming, T. H. 1977b. Response of two species of tropical heteromyid rodents to reduced food and water availability. J. Mammal. 58:102-106.

Fleming, T. H. 1983a. Carollia perspicillata (murciélago candelaro, lesser short-tailed fruit bat). Pages 457-458 in D. H. Janzen, ed. Costa Rican natural history. University of Chicago Press, Chicago. 816 pp.

Fleming, T. H. 1983b. Heteromys desmarestianus (ratón semiespinosa, spiny pocket mouse). Pages 474-475 in D. H. Janzen ed. Costa Rican natural history. University of Chicago Press, Chicago. 816 pp.

Fleming, T. H. 1988. The short-tailed fruit bat: A study in plant-animal interactions. University of Chicago Press, Chicago. 365 pp.

Fleming, T. H., and G. J. Brown. 1975. An experimental analysis of seed hoarding and burrowing behavior of two species of Costa Rican heteromyid rodents. J. Mammal. 56:301-315.

Fleming, T. H., E. T. Hooper, and D. E. Wilson. 1972. Three Central American bat communities: structure, reproductive cycles, and movement patterns. Ecology 53:555-569.

Ford, L. S., and R. S. Hoffmann. 1988. Potos flavus. Mamm. Species 321:1-9.

Foster, M. S., and R. M. Timm. 1976. Tent-making by Artibeus jamaicensis (Chiroptera: Phyllostomatidae) with comments on plants used by bats for tents. Biotropica 8:265-269.

Freese, C. H. 1983. Cebus capucinus (mono cara blanca, white-faced capuchin). Pages 458-460 in D. H. Janzen, ed. Costa Rican natural history. University of Chicago Press, Chicago. 816 pp.

Fritz, G. N. 1983. Biology and ecology of bat flies (Diptera: Streblidae) on bats in the genus Carollia. J. Med. Entomol. 20:1-10.

Fritzell, E. K., and K. J. Haroldson. 1982. Urocyon cinereoargeneteus. Mamm. Species 189:1-8.

Gardner, A. L. 1973. The systematics of the genus Didelphis (Marsupialia: Didelphidae) in North and Middle America. Spec. Publ. Mus. Tex. Tech Univ, 4:1-81.

Gardner, A. L. 1977. Feeding habits. Pages 293-350 in R. J. Baker, J. K. Jones, Jr., and D. C. Carter, eds. Biology of bats of the New World family Phyllostomatidae. Part II. Spec. Publ. Mus. Tex. Tech Univ. 13:1-364.

Gardner, A. L. 1983a. Didelphis marsupialis (raposa, zarigüeya, zorro pelón, zorra mochila, opossum). Pages 468-469 in D. H. Janzen, ed. Costa Rican natural history. University of Chicago Press, Chicago. 816 pp.

Gardner, A. L. 1983b. Oryzomys caliginosus (ratón pardo, ratón arrocero pardo, Costa Rican dusky rice rat). Pages 483-485 in D. H. Janzen, ed. Costa Rican natural history. University of Chicago Press, Chicago. $816 \mathrm{pp}$.

Gardner, A. L. 1983c. Proechimys semispinosus (Rodentia: Echimyidae): Distribution, type locality, and taxonomic history. Proc. Biol. Soc. Wash. 96:134-144.

Gardner, A. L., R. K. LaVal, and D. E. Wilson. 1970. The distributional status of some Costa Rican bats. J. Mammal. 51:712-729.

Genoways, H. H., and J. K. Jones, Jr. 1972. Variation and ecology in a local population of the vesper mouse (Nyctomys sumichrasti). Occas. Pap. Mus. Tex. Tech Univ. 3:1-22.

Glander, K. E. 1980. Reproduction and population growth in free-ranging mantled howling monkeys. Am. J. Phys. Anthropol. 53:25-36.

Glander, K. E. 1983. Alouatta palliata (congo, howling monkey, howler monkey). Pages 448-449 in D. H. Janzen, ed. Costa Rican natural history. University of Chicago Press, Chicago. 816 pp. 
Glanz, W. E., R. W. Thorington, Jr., J. Giacalone-Madden, and L. R. Heaney. 1982. Seasonal food use and demographic trends in Sciurus granatensis. Pages 239-252 in E. G. Leigh, Jr., A. S. Rand, and D. M. Windsor, eds. The ecology of a tropical forest: Seasonal rhythms and long-term changes. Smithsonian Institution Press, Washington. $468 \mathrm{pp}$.

Goldman, E. A. 1920. Mammals of Panama. Smithson. Misc. Coll. 69(5):1-309.

Gómez, L. D., and J. M. Savage. 1983. Searchers on that rich coast: Costa Rican field biology, 1400-1980. Pages 1-11 in D. H. Janzen, ed. Costa Rican natural history. University of Chicago Press, Chicago. 816 pp.

Goodwin, G. G. 1938. Four new mammals from Costa Rica. Am. Mus. Novit. 987:1-5.

Goodwin, G. G. 1940. Three new bats from Honduras and the first record of Enchisthenes harti (Thomas) for North America. Am. Mus. Nov. 1075:1-3.

Goodwin, G. G. 1943. Two new harvest mice from Costa Rica. Am. Mus. Novit. 1231:1-2. Goodwin, G. G. 1946. Mammals of Costa Rica. Bull. Am. Mus. Nat. Hist. 87:271-474.

Goodwin, G. G., and A. M. Greenhall. 1961. A review of the bats of Trinidad and Tobago: descriptions, rabies infection, and ecology. Bull. Am. Mus. Nat. Hist. 122:187-302.

Graham, G. L. 1988. Interspecific associations among Peruvian bats at diurnal roosts and roost sites. J. Mammal. 69:711-720.

Greenbaum, I. F., R. J. Baker, and D. E. Wilson. 1975. Evolutionary implications of the karyotypes of the stenodermine genera Ardops, Ariteus, Phyllops, and Ectophylla. Bull. South. Calif. Acad. Sci. 74:156-159.

Greene, H. W. 1988. Species richness in tropical predators. Pages 259-280 in F. Almeda and C. M. Pringle, eds. Tropical rainforests: diversity and conservation. California Academy of Sciences and American Association for the Advancement of Science, San Francisco. $306 \mathrm{pp}$.

Greene, H. W. 1989. Agonistic behavior by three-toed sloths, Bradypus variegatus. Biotropica. In press.

Greene, H. W., and J. B. Losos. 1988. Systematics, natural history, and conservation. BioScience 38:458-462.

Greenhall, A. M., G. Joermann, U. Schmidt, and M. R. Seidel. 1983. Desmodus rotundus. Mamm. Species 202:1-6.

Greenhall, A. M., and J. L. Paradiso. 1968. Bats and bat banding. U.S. Fish Wildl. Serv., Resour. Publ. 72.48 pp.

Greenhall, A. M., and U. Schmidt. 1988. Natural history of vampire bats. CRC Press, Inc. $246 \mathrm{pp}$.

Hafner, M. S., and D. J. Hafner. 1987. Geographic distribution of two Costa Rican species of Orthogeomys, with comments on dorsal pelage markings in the Geomyidae. Southwest. Nat. 32:5-11.

Hall, E. R. 1951. American weasels. Univ. Kans. Publ. Mus. Nat. Hist. 4:1-466.

Hall, E. R. 1960. Oryzomys couesi only subspecifically different from the marsh rice rat, Oryzomys palustris. Southwest. Nat. 5:171-173.

Hall, E. R. 1981. The mammals of North America. 2nd ed. John Wiley \& Sons, New York. 2 vols., 1:xviii $+1-600+90 ; 2:$ viii $+601-1181+90$.

Hall, E. R., and K. R. Kelson. 1959. The mammals of North America. The Ronald Press Co., New York. 2 vols., 1:xxx+1-546+79; 2:viii $+547-1083+79$.

Handley, C. O., Jr. 1966. Checklist of the mammals of Panama. Pages 753-795 in R. L. Wenzel and V. J. Tipton, eds. Ectoparasites of Panama. Field Mus. Nat. Hist. Chicago. $\mathrm{xii}+861 \mathrm{pp}$.

Handley, C. O., Jr. 1976. Mammals of the Smithsonian Venezuelan Project. Brigham Young Univ. Sci. Bull. Biol. Ser. 20(5):1-91.

Harris, W. P., Jr. 1931. A new squirrel of the Sciurus hoffmanni group from Costa Rica. Occas. Pap. Mus. Zool. Univ. Mich. 227:1-3.

Harris, W. P., Jr. 1932. Four new mammals from Costa Rica. Occas. Pap. Mus. Zool. Univ. Mich. 248:1-6. 
Harris, W. P., Jr. 1943. A list of mammals from Costa Rica. Occas. Pap. Mus. Zool. Univ. Mich. 476:1-15.

Harrison, D. L. 1975. Macrophyllum macrophyllum. Mamm. Species 62:1-3.

Hartshorn, G. S. 1983. Plants. Pages 118-157 in D. H. Janzen, ed. Costa Rican natural history. University of Chicago Press, Chicago. $816 \mathrm{pp}$.

Hartshorn, G., and R. Peralta. 1988. Preliminary description of primary forests along the La Selva-Volcán Barva altitudinal transect, Costa Rica. Pages 281-296 in F. Almeda and C. M. Pringle, eds. Tropical rainforests: diversity and conservation. California Academy of Sciences and American Association for the Advancement of Science, San Francisco. 306 pp.

Heaney, L. R. 1983. Sciurus granatensis (ardilla roja, ardilla chisa, red-tailed squirrel). Pages $489-490$ in D. H. Janzen, ed. Costa Rican natural history. University of Chicago Press, Chicago. 816 pp.

Heithaus, E. R., T. H. Fleming, and P. A. Opler. 1975. Foraging patterns and resource utilization in seven species of bats in a seasonal tropical forest. Ecology 56:841-854.

Herd, R. M. 1983. Pteronotus parnellii. Mamm. Species 209:1-5.

Hershkovitz, P. 1950. Mammals of northern Colombia. Preliminary report no. 6: Rabbits (Leporidae), with notes on the classification and distribution of the South American forms. Proc. U.S. Natl. Mus. 100(3265):327-375.

Hershkovitz, P. 1987. First South American record of Coues' marsh rice rat, Oryzomys couesi. J. Mammal. 68:152-154.

Hill, J. E. 1964. Notes on bats from British Guiana, with the description of a new genus and species of Phyllostomatidae. Mammalia 28:553-572.

Holdridge, L. R. 1967. Life zone ecology. Tropical Science Center, San José, Costa Rica. $206 \mathrm{pp}$.

Holdridge, L. R., W. C. Grenke, W. H. Hatheway, T. Liang, and J. A. Tosi, Jr. 1971. Forest environments in tropical life zones: a pilot study. Pergamon Press, New York. xxxi $+747 \mathrm{pp}$.

Honacki, J. H., K. E. Kinman, and J. W. Koeppl. 1982. Mammal species of the world. Allen Press Inc. and Association of Systematics Collections, Lawrence, Kans. ix +694 pp.

Hood, C. S., and J. K. Jones, Jr. 1984. Noctilio leporinus. Mamm. Species 216:1-7.

Hood, C. S., and J. Pitocchelli. 1983. Noctilio albiventris. Mamm. Species 197:1-5.

Howell, D. J. 1983. Glossophaga soricina (murciélago lengualarga, nectar bat). Pages 472-474 in D. H. Janzen, ed. Costa Rican natural history. University of Chicago Press, Chicago. 816 pp.

Howell, D. J., and D. Burch. 1974. Food habits of some Costa Rican bats. Rev. Biol. Trop. 21:281-294.

Huckaby, D. G. 1980. Species limits in the Peromyscus mexicanus group (Mammalia: Rodentia: Muroidea). Contrib. Sci. (Los Angel.) 326:1-24.

Husson, A. M. 1978. The mammals of Suriname. Zoöl. Mongr. Rijksmus. Nat. Hist., Leiden $2: x x x i v+1-569+151$ plates.

Janzen, D. H. 1983a. Coendou mexicanum (puercoespín, prehensile-tailed porcupine). Pages 460-461 in D. H. Janzen, ed. Costa Rican natural history. University of Chicago Press, Chicago. $816 \mathrm{pp}$.

Janzen, D. H. 1983b. Canis latrans (coyote). Pages 456-457 in D. H. Janzen, ed. Costa Rican natural history. University of Chicago Press, Chicago. $816 \mathrm{pp}$.

Janzen, D. H. 1983c. Eira barbara (tolumuco, tayra). Pages 469-470 in D. H. Janzen, ed. Costa Rican natural history. University of Chicago Press, Chicago. $816 \mathrm{pp}$.

Janzen, D. H. 1983e. Odocoileus virginianus (venado, venado cola blanca, white-tailed deer). Pages 481-483 in D. H. Janzen, ed. Costa Rican natural history. University of Chicago Press, Chicago. 816 pp.

Janzen, D. H. 1983d. Tapinus bairdii (danto, danta, Baird's tapir). Pages $496-497$ in D. H. Janzen, ed. Costa Rican natural history. University of Chicago Press, Chicago. 816 pp. 
Jeanne, R. L. 1970. Note on a bat (Phylloderma stenops) preying upon the brood of a social wasp. J. Mammal. 51:624-625.

Jones, J. K., Jr., J. R. Choate, and A. Cadena. 1972. Mammals from the Mexican State of Sinaloa. II. Chiroptera. Occas. Pap. Mus. Nat. Hist. Univ. Kans. 6:1-29.

Jones, J. K., Jr., and M. D. Engstrom. 1986. Synopsis of the rice rats (genus Oryzomys) of Nicaragua. Occas. Pap. Mus. Tex. Tech Univ. 103:1-23.

Jones, J. K., Jr., and J. A. Homan. 1974. Hylonycteris underwoodi. Mamm. Species 32:1-2.

Kaufmann, J. H. 1962. Ecology and social behavior of the coati, Nasua narica, on Barro Colorado Island, Panama. Univ. Calif. Publ. Zool. 60(3):95-222.

Kaufmann, J. H. 1983. Nasua narica (pizote, coati). Pages 478-480 in D. H. Janzen, ed. Costa Rican natural history. University of Chicago Press, Chicago. 816 pp.

Koford, C. B. 1983a. Felis onca (tigre, jaguar). Pages 470-471 in D. H. Janzen, ed. Costa Rican natural history. University of Chicago Press, Chicago. 816 pp.

Koford, C. B. 1983b. Felis wiedii (tigrillo, caucel, margay). Pages 471-472 in D. H. Janzen, ed. Costa Rican natural history. University of Chicago Press, Chicago. 816 pp.

Koopman, K. F. 1976. Zoogeography. Pages 39-47 in R. J. Baker, J. K. Jones, Jr., and D. C. Carter, eds. Biology of bats of the New World family Phyllostomatidae. Part I. Spec. Publ. Mus. Tex. Tech Univ. 10:1-218.

Kortlucke, S. M. 1973. Morphological variation in the kinkajou, Potos flavus (Mammalia: Procyonidae), in Middle America. Occas. Pap. Mus. Nat. Hist. Univ. Kans. 17:1-36.

Larson, D., and H. F. Howe. 1987. Dispersal and destruction of Virola surinamensis seeds by agoutis: appearance and reality. J. Mammal. 68:859-860.

Lassieur, S., and D. E. Wilson. 1989. Lonchorhina aurita. Mamm. Species 347:1-4.

LaVal, R. K. 1973a. A revision of the Neotropical bats of the genus Myotis. Sci. Bull. Nat. Hist. Mus. Los Angeles Co. 15:1-54.

LaVal, R. K. 1973b. Systematics of the genus Rhogeessa (Chiroptera: Vespertilionidae). Occas. Pap. Mus. Nat. Hist. Univ. Kans. 19:1-47.

LaVa, R. K. 1977. Notes on some Costa Rican bats. Brenesia 10/11:77-83.

LaVal, R. K., and H. S. Fitch. 1977. Structure, movements and reproduction in three Costa Rican bat communities. Occas. Pap. Mus. Nat. Hist. Univ. Kans. 69:1-28.

LaVal, R. K., and M. L. LaVal. 1980. Prey selection by a Neotropical foliage-gleaning bat, Micronycteris megalotis. J. Mammal. 61:327-330.

Lewis, S. E., and D. E. Wilson. 1987. Vampyressa pusilla. Mamm. Species 292:1-5.

Lieberman, D., M. Lieberman, R. Peralta, and G. S. Hartshorn. 1985. Mortality patterns and stand turnover rates in a wet tropical forest in Costa Rica. J. Ecol. 73:915-924.

Lieberman, M., D. Lieberman, G. S. Hartshom, and R. Peralta. 1985. Small-scale altitudinal variation in lowland wet tropical forest vegetation. J. Ecol. 73:505-516.

Lotze, J.-H., and S. Anderson. 1979. Procyon lotor. Mamm. Species 119:1-8.

Lubin, Y. D. 1983. Tamandua mexicana (oso jaceta, hormiguero, tamandua, banded anteater, lesser anteater). Pages 494-496 in D. H. Janzen, ed. Costa Rican natural history. University of Chicago Press, Chicago. 816 pp.

Lumer, C., and R. D. Schoer. 1986. Pollination of Blakea austin-smithii and B. penduliflora (Melastomataceae) by small rodents in Costa Rica. Biotropica 18:363-364.

Mares, M. A., M. R. Willig, K. E. Streilein, and T. E. Lacher, Jr. 1981. The mammals of northeastern Brazil: A preliminary assessment. Ann. Carnegie Mus. 50:81-137.

Mares, M. A., and D. E. Wilson. 1971. Bat reproduction during the Costa Rican dry season. BioScience 21:471-472, 477.

Marshall, L. G. 1978. Chironectes minimus. Mamm. Species 109:1-6.

Mascarello, J. T., and D. S. Rogers. 1988. Banded chromosomes of Liomys salvini, Heteromys oresterus, and $H$. desmarestianus. J. Mammal. 69:126-130.

Mayer, J. J., and R. M. Wetzel. 1987. Tayassu pecari. Mamm. Species 293:1-7.

McBee, K., and R. J. Baker. 1982. Dasypus novemcinctus. Mamm. Species 162:1-9.

McCarthy, T. J. 1987. Additional mammalian prey of the carnivorous bats, Chrotopterus auritus and Vampyrum spectrum. Bat Res. News 28(1-2):1-3. 
McCarthy, T. J., A. Cadena G., and T. O. Lemke. 1983. Comments on the first Tonatia carrikeri (Chiroptera: Phyllostomatidae) from Colombia. Lozania (Acta Zool. Colombiana) 40:1-6.

McHargue, L. A., and G. S. Hartshorn. 1983. Seed and seedling ecology of Carapa guianensis. Turrialba 33:399-404.

McPherson, A. B. 1985. A biogeographical analysis of factors influencing the distribution of Costa Rican rodents. Brenesia 23:97-273.

McPherson, A. B. 1986. The biogeography of Costa Rican rodents: an ecological, geological, and evolutionary approach. Brenesia 25-26:229-244.

McPherson, A. B., R. Zeledón, and S. Shelton. 1985. Comments on the status of Metachirus nudicaudatus dentatus (Goldman, 1912) in Costa Rica. Brenesia 24:375-377.

Medellín, R. A. 1988. Prey of Chrotopterus auritus, with notes on feeding behavior. J. Mammal. 69:841-844.

Medellín, R. A., D. E. Wilson, and D. Navarro L. 1985. Micronycteris brachyotis. Mamm. Species 251:1-4.

Monge-N., J., and B. Morera-B. 1986. La dispersion del coyote (Canis latrans) y la evidencia de los antiguos cronistas. Brenesia 25-26:251-260.

Monge-N., J., and B. Morera-B. 1987. Why is the coyote (Canis latrans) expanding its range? A critique of the deforestation hypothesis. Rev. Biol. Trop. 35:169-171.

Montgomery, G. G., editor. 1978. The ecology of arboreal folivores. Smithsonian Institution Press, Washington. 574 pp.

Montgomery, G. G. 1983a. Bradypus variegatus (perezoso de tres dedos, three-toed sloth). Pages 453-456 in D. H. Janzen, ed. Costa Rican natural history. University of Chicago Press, Chicago. 816 pp.

Montgomery, G. G. 1983b. Cyclopes didactylus (tapacara, serafin de platanar, silky anteater). Pages 461-463 in D. H. Janzen, ed. Costa Rican natural history. University of Chicago Press, Chicago. 816 pp.

Montgomery, G. G., editor. 1985. The evolution and ecology of armadillos, sloths, and vermilinguas. Smithsonian Institution Press, Washington. $451 \mathrm{pp}$.

Morrison, D. W. 1983. Artibeus jamaicensis (murciélago frutero Jamaicano, Jamaican fruit bat). Pages 449-451 in D. H. Janzen, ed. Costa Rican natural history. University of Chicago Press, Chicago. 816 pp.

Myers, N. 1986. Tropical deforestation and a mega-extinction spasm. Pages 394-409 in M. E. Soule, ed. Conservation biology: the science of scarcity and diversity. Sinauer Associates, Inc., Sunderland, Mass. 584 pp.

Myers, P. 1977. Patterns of reproduction of four species of vespertilionid bats in Paraguay. Univ. Calif. Publ. Zool. 107:1-41+11 plates.

Nagorsen, D., and J. R. Tamsitt. 1981. Systematics of Anoura cultrata, A. brevirostrum, and $A$. werckleae. J. Mammal. 62:82-100.

Navarro L., D., and D. E. Wilson. 1982. Vampyrum spectrum. Mamm. Species 184:1-4.

Nelson, C. E. 1965. Lonchorhina aurita and other bats from Costa Rica. Tex. J. Sci. 17:303-306.

Nitikman, L. Z. 1985. Sciurus granatensis. Mamm. Species 246:1-8.

Nowak, R. M., and J. L. Paradiso. 1983. Walker's mammals of the world. 4th ed. The Johns Hopkins University Press, Baltimore, Md. 1-2:1-1362.

Oficina de Planificación del Sector Agropecuario. 1979. Comportamiento del sector forestal durante el periódo 1950-1977. Oficina de Planificación del Sector Agropecuario. 59 pp.

Owen, R. D. 1987. Phylogenetic analysis of the bat subfamily Stenodermatinae (Mammalia: Chiroptera). Spec. Publ. Mus. Tex. Tech Univ. 26:1-65.

Pine, R. H. 1971. A review of the lorg-whiskered rice rat, Oryzomys bombycinus Goldman. J. Mammal. 52:590-596.

Pine, R. H. 1972. The bats of the genus Carollia. Tex. Agric. Exp. Stn. Tech. Monogr . Texas A \& M University 8:1-125. 
Pringle, C., I. Chacón, M. Grayum, H. Greene, G. Hartshorn, G. Schatz, G. Stiles, C. Gómez, and M. Rodríguez. 1984. Natural history observations and ecological evaluation of the La Selva Protection Zone, Costa Rica. Brenesia 22:189-206.

Rabinowitz, A. R., and B. G. Nottingham, Jr. 1986. Ecology and behavior of the jaguar (Panthera onca) in Belize, Central America. J. Zool. (Lond.) 210:149-159.

Rasweiler, J. J., IV. 1982. The contribution of observations on early pregnancy in the little sac-winged bat, Peropteryx kappleri, to an understanding of the evolution of reproductive mechanisms in monovular bats. Biol. Reprod. 27:681-702.

Rogers, D. S., I. F. Greenbaum, S. J. Gunn, and M. D. Engstrom. 1984. Cytosystematic value of chromosomal inversion data in the genus Peromyscus (Rodentia: Cricetidae). J. Mammal. 65:457-465.

Sader, S. A., and A. T. Joyce. 1988. Deforestation rates and trends in Costa Rica, 1940 to 1983. Biotropica 20:11-19.

Sanborn, C. C. 1932. Neotropical bats in the Carnegie Museum. Ann. Carnegie Mus. 21:171-183.

Sanborn, C. C. 1937. American bats of the subfamily Emballonurinae. Field Mus. Nat. Hist. Publ. Zool. Ser. 20:321-354.

Sanborn, C. C. 1941. Descriptions and records of Neotropical bats. Field Mus. Nat. Hist. Publ. Zool. Ser. 27:371-387.

Sanborn, C. C. 1949. Bats of the genus Micronycteris and its subgenera. Fieldiana Zool. 31:215-233.

Sánchez H., C., and C. B. Chávez T. 1984. Observaciones sobre la biologiá del murciélago de cápula Diclidurus virgo Thomas. Actas II Reunión Iberoamer. Conserv. Zool. Vert. pages $411-416$.

Sanderson, G. C. 1983. Procyon lotor (mapache, raccoon). Pages 485-488 in D. H. Janzen, ed. Costa Rican natural history. University of Chicago Press, Chicago. $816 \mathrm{pp}$.

Savage, J. M. 1974. The Isthmian Link and the evolution of Neotropical mammals. Contrib. Sci. (Los Angel.) 260:1-51.

Sawyer, J. O., and A. A. Lindsey. 1971. Vegetation of the life zones in Costa Rica. Ind. Acad. Sci. Monogr. 2:1-214.

Sisk, T., and C. Vaughan. 1984. Notes on some aspects of the natural history of the giant pocket gopher (Orthogeomys Merriam) in Costa Rica. Brenesia 22:233-247.

Slud, P. 1960. The birds of Finca "La Selva," Costa Rica: a tropical wet forest locality. Bull. Am. Mus. Nat. Hist. 121:49-148 + 26 plates.

Smith, J. D. 1972. Systematics of the chiropteran family Mormoopidae. Misc. Publ. Mus. Nat. Hist. Univ. Kans. 56:1-132.

Smith, S. A., R. D. Bradley, and I. F. Greenbaum. 1986. Karyotypic conservatism in the Peromyscus mexicanus group. J. Mammal. 67:584-586.

Smythe, N. 1978. The natural history of the Central American agouti (Dasyprocta punctata). Smithson. Contrib. Zool. 257:1-52.

Smythe, N. 1983. Dasyprocta punctata and Agouti paca (guatusa, cherenga, agouti, tepezcuintle, paca). Pages 463-465 in D. H. Janzen, ed. Costa Rican natural history. University of Chicago Press, Chicago. 816 pp.

Sowls, L. K. 1983. Tayassu tajacu (saino, collared peccary). Pages 497-498 in D. H. Janzen, ed. Costa Rican natural history. University of Chicago Press, Chicago. 816 pp.

Starrett, A. 1969. A new species of Anoura (Chiroptera: Phyllostomatidae) from Costa Rica. Contrib. Sci. (Los Angel.) 157:1-9.

Starrett, A. 1972. Cyttarops alecto. Mamm. Species 13:1-2.

Starrett, A., and R. S. Casebeer. 1968. Records of bats from Costa Rica. Contrib. Sci. (Los Angel.) 148:1-21.

Starrett, A., and L. de la Torre. 1964. Notes on a collection of bats from Central America, with the third record for Cyttarops alecto Thomas. Zoologica 49:53-63.

Tamsitt, J. R., and D. Nagorsen. 1982. Anoura cultrata. Mamm. Species 179:1-5. 
Tamsitt, J. R., and D. Valdivieso. 1961. Notas sobre actividades nocturnas y estados de reproducción de algunos quirópteros de Costa Rica. Rev. Biol. Trop. 9:219-225.

Thomas, O. 1912. New Centronycteris and Ctenomys from S. America. Ann. Mag. Nat. Hist. Ser. 8, 10:638-640.

Thomas, O. 1913. On some rare Amazonian mammals from the collection of the Para Museum. Ann. Mag. Nat. Hist. Ser, 8, 11:130-136.

Timm, R. M. 1982. Ectophylla alba. Mamm. Species 166:1-4.

Timm, R. M. 1984. Tent construction by Vampyressa in Costa Rica. J. Mammal. 65:166-167.

Timm, R. M. 1985. Artibeus phaeotis. Mamm. Species 235:1-6.

Timm, R. M. 1987. Tent construction by bats of the genera Artibeus and Uroderma. Pages 187-212 in B. D. Patterson and R. M. Timm, eds. Studies in Neotropical mammalogy: essays in honor of Philip Hershkovitz. Fieldiana Zool. (New Series) 39:1-506.

Timm, R. M. 1989. A review and reappraisal of the night monkey, Aotus lemurinus (Primates: Cebidae), in Costa Rica. Rev. Biol. Trop. In press.

Timm, R. M. The mammalian fauna of La Selva. In L. A. McDade, K. S. Bawa, H. A. Hespenheide, and G. S. Hartshorn, eds. La Selva: ecology and natural history of a Neotropical rainforest. Organization for Tropical Studies and University of Chicago Press, Chicago. In press.

Timm, R. M., and J. Mortimer. 1976. Selection of roost sites by Honduran white bats, Ectophylla alba (Chiroptera: Phyllostomatidae). Ecology 57:385-389.

Turner, D. C. 1975. The vampire bat: a field study in behavior and ecology. The Johns Hopkins University Press, Baltimore. 145 pp.

Turner, D. C. 1983. Desmodus rotundus (vampiro, vampire bat). Pages 467-468 in D. H. Janzen, ed. Costa Rican natural history. University of Chicago Press, Chicago. $816 \mathrm{pp}$.

Tuttle, M. D. 1970. Distribution and zoogeography of Peruvian bats, with comments on natural history. Univ. Kans. Sci. Bull. 49:45-86.

Tuttle, M. D. 1976. Collecting techniques. Pages 71-88 in R. J. Baker, J. K. Jones, Jr., and D. C. Carter, eds. Biology of bats of the New World family Phyllostomatidae. Part $\mathbf{I}$. Spec. Publ. Mus., Tex. Tech Univ. 10:1-218.

Tuttle, M. D., and M. J. Ryan. 1981. Bat predation and the evolution of frog vocalizations in the neotropics. Science 214:677-678.

Uieda, W., I. Sazima, and A. Storti Filho. 1980. Aspectos da biologia do morcego Furipterus horrens (Mammalia, Chiroptera, Furipteridae). Rev. Brasil. Biol. 40:59-66.

United States Department of State. 1981. The world's tropical forests: a United States policy, strategy and program. United States Department of State, Washington, D.C. 53 pp.

Vandermeer, J. H. 1979. Hoarding behavior of captive Heteromys desmarestianus, (Rodentia) on the fruits of Welfia georgii, a rainforest dominant palm in Costa Rica. Brenesia 16:107-116.

Vandermeer, J. H., J. Stout, and S. Risch. 1979. Seed dispersal of a common Costa Rican rain forest palm (Welfia georgii). Trop. Ecol. 20:17-26.

Vaughan, C. 1983a. A report on dense forest habitat for endangered wildlife species in Costa Rica. National University, Heredia, Costa Rica. 66 pp. + 33 maps.

Vaughan, C. 1983b. Coyote range expansion in Costa Rica and Panama. Brenesia 21:27-32.

Vaughan, C., and M. Rodriguez. 1986. Comparacion de los habitos alimentarios del coyote (Canis latrans) en dos localidades en Costa Rica. Vida Silvestre Neotrop. 1:6-11.

Vehrencamp, S. L., F. G. Stiles, and J. W. Bradbury. 1977. Observations on the foraging behavior and avian prey of the Neotropical carnivorous bat, Vampyrum spectrum. J. Mammal. 58:469-478.

Villa-R., B. 1967. Los murciélagos de Mexico. Univ. Nac. Autónoma Mexico, An. Inst. Biol. xvi +491 pp.

von Frantzius, A. 1881. Mamíferos de Costa Rica. Collección de Documentos para la Historia de Costa Rica, Publicados por el Don Leon Fernandez, San José de Costa Rica. 442 pp. 
Walton, D. W. 1963. A collection of the bat Lonchophylla robusta Miller from Costa Rica. Tulane Studies Zool. 10:87-90.

Webster, W. D., and J. K. Jones, Jr. 1982a. Artibeus aztecus. Mamm. Species 177:1-3. Webster, W. D., and J. K. Jones, Jr. 1982b. Artibeus toltecus. Mamm. Species 178:1-3. Wetzel, R. M. 1980. A revision of the naked-tailed armadillos, genus Cabassous McMurtrie. Ann. Carnegie Mus. Nat. Hist. 49:323-357.

Wetzel, R. M. 1982. Systematics, distribution, ecology, and conservation of South American edentates. Pages 345-375 in M. A. Mares and H. H. Genoways, eds. Mammalian biology in South America. Pymatuning Laboratory of Ecology, University of Pittsburgh. Spec. Publ. Ser. 6. xii +539 pp.

Wetzel, R. M. 1983. Dasypus novemcinctus (cusuco, armadillo). Pages 465-467 in D. H. Janzen, ed. Costa Rican natural history. University of Chicago Press, Chicago. 816 pp.

Wetzel, R. M. 1985. Taxonomy and distribution of armadillos, Dasypodidae. Pages 23-46 in G. G. Montgomery, ed. The evolution and ecology of armadillos, sloths, and vermilinguas. Smithsonian Institution Press, Washington, D.C. 451 pp.

Williams, K. D. 1984. The Central American tapir (Tapirus bairdii Gill) in northwestern Costa Rica. Ph.D. dissertation, Michigan State University, East Lansing.

Williams, S. L., and H. H. Genoways. 1980. Results of the Alcoa Foundation-Suriname Expeditions. II. Additional records of bats (Mammalia: Chiroptera) from Suriname. Ann. Carnegie Mus. 49:213-236.

Willig, M. R. 1985. Reproductive patterns of bats from Caatingas and Cerrado biomes in northeast Brazil. J. Mammal. 66:668-681.

Wilson, D. E. 1971a. Food habits of Micronycteris hirsuta (Chiroptera: Phyllostomidae). Mammalia 35:107-110.

Wilson, D. E. 1971b. Ecology of Myotis nigricans (Mammalia: Chiroptera) on Barro Colorado Island, Panama Canal Zone. J. Zool. (Lond.) 163:1-13.

Wilson, D. E. 1973a. Bat faunas: A trophic comparison. Syst. Zool. 22:14-29.

Wilson, D. E. 1973b. Reproduction in neotropical bats. Period. Biol. 75:215-217.

Wilson, D. E. 1979. Reproductive patterns. Pages 317-378 in R. J. Baker, J. K. Jones, Jr., and D. C. Carter, eds. Biology of bats of the New World family Phyllostomatidae. Part III. Spec. Publ. Mus. Tex. Tech Univ. 16:1-441.

Wilson, D. E. 1983a. Checklist of mammals. Pages 443-447 in D. H. Janzen, ed. Costa Rican natural history. University of Chicago Press, Chicago. $816 \mathrm{pp}$.

Wilson, D. E. 1983b. Myotis nigricans (murciélago pardo, black myotis). Pages 477-478 in D. H. Janzen, ed. Costa Rican natural history. University of Chicago Press, Chicago. $816 \mathrm{pp}$.

Wilson, D. E. 1989. The mammals of La Selva, Costa Rica. In A. C. Gentry, ed. Four Neotropical forests. Yale Univ. Press, New Haven. In press.

Wilson, D. E., and J. S. Findley, 1977. Thyroptera tricolor. Mamm. Species 71:1-3.

Wilson, D. E., and R. K. LaVal. 1974. Myotis nigricans. Mamm. Species 39:1-3.

Wujek, D. E., and P. Timpano. 1986. Rufusia (Porphyridiales, Phragmonemataceae), a new red alga from sloth hair. Brenesia 25-26:163-168.

Young, A. M. 1971. Foraging of vampire bats (Desmodus rotundus) in Atlantic wet lowland Costa Rica. Rev. Biol. Trop. 18:73-88. 